\title{
Modeling and Simulation of Photovoltaic Systems in Indonesia
}

A technical evaluation at multiple levels 



\title{
MODELING AND SIMULATION OF PHOTOVOLTAIC SYSTEMS IN INDONESIA
}

\author{
A TECHNICAL EVALUATION AT MULTIPLE LEVELS
}

\section{PROEFSCHRIFT}

\author{
ter verkrijging van \\ de graad van doctor aan de Universiteit Twente, \\ op gezag van de rector magnificus, \\ prof. dr. H. Brinksma, \\ volgens besluit van het College voor Promoties \\ in het openbaar te verdedigen \\ op woensdag 3 juni 2015 om 14:45 uur
}

door

Anton Johannes Veldhuis

geboren op 27 september 1985

te Apeldoorn 
Dit proefschrift is goedgekeurd door de promotoren:

Prof. dr. ir. F.J.A.M. van Houten

Prof. dr. A.H.M.E. Reinders

ISBN: 978-90-365-3865-7

Copyright (C) Hans Veldhuis, 2015 


\section{MODELING AND SIMULATION OF PHOTOVOLTAIC SYSTEMS IN INDONESIA}

A TECHNICAL EVALUATION AT MULTIPLE LEVELS 
De promotiecommissie:

Prof. dr. G.P.M.R. Dewulf

Prof. dr. ir. F.J.A.M. van Houten

Prof. dr. A.H.M.E. Reinders

Prof. dr. ir. J.L.M. Hensen

Prof. dr. ir. R.E.I. Schropp

Dr. W.G.J.H.M. van Sark

Prof. dr. ir. A. de Boer

Prof. dr. ir. T.H. van der Meer
Universiteit Twente, voorzitter en secretaris

Universiteit Twente, promotor

Universiteit Twente, promotor

Technische Universiteit Eindhoven

Technische Universiteit Eindhoven

Universiteit Utrecht

Universiteit Twente

Universiteit Twente

The author gratefully acknowledges the support of the INDF project 'Joint Development of a Knowledge Centre on Solar Energy' (INDF10RI12) of the Dutch Ministry of Economic Affairs.

ISBN: 978-90-365-3865-7

Printed by Ipskamp Drukkers BV, Enschede, The Netherlands

Copyright (C) Hans Veldhuis, 2015

All rights reserved. No part of this publication may be reproduced, stored in a retrieval system or transmitted, in any form or by any means, electronic, mechanical, photocopying, recording or otherwise, without the prior written permission of the author. 



\section{Preface}

So.. Where to start? Maybe just at the beginning. During the last part of my master assignment in the end of 2010, my supervisor Angèle Reinders asked me if I enjoyed the kind of work I did. I did. Some weeks later - mid-December - she showed me a project proposal about PV systems in Indonesia and asked me if I would be interested in it. It would be a PhD position for an initial duration of three years. If I could decide as soon as possible, because the project would start by the end of January already. I got a copy of the proposal and some time to think about it. During that period I was already carefully looking around for a job, but doing a PhD had never crossed my mind.

Time for a weekend Paris with some old (but still young) friends. Questioning the next step in my life. Begin 2011, after weighing the pros and cons, I decided to take the opportunity. Friday the $11^{\text {th }}$ of February I received my master diploma, next Thursday I was underway to Jakarta: I got off to a flying start.

The term 'journey' has been more than just a metaphor for the process of getting a $\mathrm{PhD}$. Jakarta, Bandung, Jayapura, Seattle, New Delhi, Mumbai, Kuala Lumpur, Denpasar, Yogyakarta, Surabaya, Berlin, Frankfurt, London, Singapore, Tampa, Miami, New Orleans, Houston, Austin, San Antonio, Albuquerque, Phoenix, Las Vegas, San Francisco, Edinburgh, Hong Kong, Denver, Kansas City, St. Louis, Chicago, Buffalo, New York, Amsterdam, Nice and Enschede. By now, I can assure that the sun shines in all these cities. If you don't believe it, discover it by yourself, it is worth it. The past years were an amazing journey which finally resulted in this thesis, but this has not been possible without the help of many people.

I would like to thank my supervisor, Fred van Houten, for giving me the freedom to explore and for the financial support during the fourth year, which allowed me to finish my thesis. Many thanks go to my daily supervisor. Angèle, thank you for this great opportunity, for the useful comments and all the textual revisions.

A lot of people have been involved in the project during the past years in Indonesia, I cannot thank you all personally, but I would like to thank you all for the pleasant collaboration. Colleagues from ITB: Armi, Yuli and pak Halim, thank you for your support and hospitality during the project. Mamad, Leny, Indri and Cha, thanks for the pleasant times in Bandung. Mamad, thank you for bringing me to Tri Mumpuni by motorcycle, wishing you good luck. From WWF Indonesia: Sherlly, Retno, Nyoman, thanks for your cooperation. Sherlly, thank you for showing me around in Jayapura, I still remember your 
granddad reciting the Dutch provinces. Thijs, thanks for your support and good luck with Solinvest! The staff from Pemda at Kantor Walikota: Henny, Ari, Frengki, ibu Ketty and many others, thanks for the great collaboration! Special words of thanks go to Frengki for his work to download and send the monitoring data from the PV system in Jayapura.

\section{Terima kasih!}

Bob, Karyo and Nova, thanks for the collaboration during the installation of the PV system in Jayapura. After some delays, asking when the installation would be finished, got replied by the running gag: "May, may be, may be not". Finally, the installation was finished in May. Bob, you've shown that both many hands and PV make light work, it has been a pleasure to spend some time with you in Jayapura and Bali.

I also would like to thank some colleagues at SERIS. Thomas, thank you for sharing the measurement data from one of the PV systems in Singapore. André, thanks for the pleasant collaboration during the last two years of my $\mathrm{PhD}$. The different time zones allowed us to work around-the-clock which was beneficial close to deadlines. Wishing you all the best and maybe our paths will cross again. Marius, thanks for your useful comments and I wish you good luck at MIT.

Yet, I spent most of the time during my PhD at the department of Design, Production and Management of the University of Twente. The coffee breaks were always a pleasant distraction from work. It were not so much the breaks itself, but especially the friendly colleagues who made these breaks pleasant, I'll certainly miss this. Besides, I enjoyed the activities organized by the OPM department, such as the regular barbecues and the 'batavierenrace'. Thanks for all these nice moments!

N211, if you had some luck and tried your best, you could also find moments with just a little bit of distraction in this room. These moments were mostly used to get some work done. And indeed, a $\mathrm{PhD}$ position offers some perspective: students, dignitaries, leaf blowers and the yearly recurring and reproducing magpies. Entertainment enough. I am glad to have been part of N211 and I would like to thank everyone who has shared this room with me in the past years, but in particular Jos, Maarten, Frederik and, although not seated but often present in N211, Tox. Toxopedeus, the god of the free assignments, it was always nice to have you around at unorthotox moments. Frederik, without your presence the past years would have been less filled with funniness. "Hallo?", fortunately there was still a telephone for direct communications every now and then, after you moved to another office. Maarten, I still can't visit the Beiaard without being offered a Goldstrike, thanks for that! I hope we can drink it together there once more. Once. Wishing you good luck in finishing your thesis, you are a nice person. Jos, your sense of humour has contributed to what $\mathrm{N} 211$ was and I am happy I got to know you. 
Running is an excellent way of keeping your mind and body in balance, particularly during the last phase of writing. Winnie, thanks for introducing me to trail running, I still enjoy this and I hope you'll join again speedily, but not hurried.

Arthur, I am glad you stayed in Enschede and I am happy to have you as a friend. You contributed to a large part of the journey, literally. The two road trips through the USA are experiences of a lifetime which wouldn't have been the same without you. Oh, and thanks for the chili!

Old (but still young) friends, Ruben, Andreas and Nando, we know each other quite some years already, I am happy to have friends like you. The vacations and weekend trips together are always fun, let's plan the next one soon.

Jan-Willem en Thijs, ik ben blij dat jullie er zijn! Last but not least, papa en mama, bedankt voor jullie liefde en steun. Met de basis die jullie mij gegeven hebben en jullie ook nog steeds zijn, zie ik de toekomst zonnig tegemoet. Dank!

Hans

Enschede, May 2015 


\section{Summary}

With over 8,000 inhabited islands, the distribution of fuels and electricity is extremely challenging in Indonesia. The country struggles to increase its electrification rate while keeping pace with the growing electricity demand. Because of the abundance of solar radiation combined with the problems associated with rural electrification, historically Indonesia was seen as an ideal candidate for the early adoption of off-grid photovoltaic (PV) systems. In the 90s many foreign aid organizations initiated off-grid PV programs in Indonesia. Due to several reasons, these off-grid PV projects had varying degrees of success and some failed to supply adequate electricity to households. However, the global installations of - mainly grid-connected - PV systems have increased tremendously in past years, contributing to declining costs and the maturing of the technology. Therefore, PV systems could offer new opportunities for Indonesia. At the same time, depleting fossil energy resources and the increasing awareness of climate change caused by $\mathrm{CO}_{2}$ emissions create an environment wherein PV systems could become increasingly important for the future electricity mix of Indonesia. To stimulate this transition, it is necessary that existing barriers to a successful implementation are indicated in order to be tackled.

This thesis adds to this objective by enhancing the technical knowledge about PV systems in Indonesia. This has been achieved by modeling and simulation of PV systems. The main research question in this thesis is: What can be learned from experiences with and modeling of PV systems for the stimulation of PV in the future electricity mix in Indonesia?

Since the successful implementation of PV systems depends on several factors, the PV systems have been evaluated at three different levels, namely at a national, system and product level.

The main research question at the national level is: What is the potential and costeffectiveness of PV systems in Indonesia? To answer this question, the potential and costs of PV systems have been modeled and evaluated. For this purpose, a distinction has been made between grid-connected and off-grid PV systems. Since large geographic variations exist in Indonesia, the potential nominal installed capacity and levelized cost of electricity (LCOE) of PV systems have been determined for each province of Indonesia. The potential has been based on publicly available statistics and figures found in literature.

To determine the potential of grid-connected PV systems four areas have been distinguished: urban cores, suburban areas, grid-connected rural villages and off-grid rural areas. Based on the electrification and urbanization rates the population living in these different areas has been determined. Subsequently, the size of each area has been calculated based on average population densities for each area. For each area a land availability factor 
and a performance ratio for the PV systems have been assumed. In combination with the average daily irradiance per province, the potential of grid-connected PV has been determined. To assess the cost-effectiveness the LCOE has been compared with the generation costs of electricity based on data from the state-owned electricity company (PLN).

From this study it can be concluded that the total technical potential of grid-connected $\mathrm{PV}$ in Indonesia is roughly $1,100 \mathrm{GW}_{\mathrm{p}}$, generating about $1,490 \mathrm{TWh}$ which is 10 times more than the electricity consumed in Indonesia in 2010.

Taking into account constraints of the present electricity demand during day-time and a minimal base load of conventional power systems, the total potential is less, namely about $28 \mathrm{GW}_{\mathrm{p}}$, generating $37 \mathrm{TWh} /$ year, which is about $25 \%$ of the total electricity consumption in Indonesia in 2010. Compared with the energy potential of other renewables in Indonesia, the present restricted potential of grid-connected PV is similar to the resource potential of geothermal energy, roughly the half of the potential for biomass and three times the resource potential of wind.

The estimated LCOE of grid-connected PV systems ranges from 0.15 to $0.24 \$ / \mathrm{kWh}$ and is already cost-effective in the provinces West-Kalimantan, North-Maluku, Maluku, West and East Nusa Tenggara, Bangka-Belitung, West Papua and Papua. Besides, it is expected that this will be the case in the provinces of Kalimantan, Sulawesi, West and North Sumatra, Riau, Riau islands and the province of Aceh in the near future.

The evaluation of the potential of off-grid PV systems focuses on the population in rural areas which lacks access to electricity. Two off-grid PV system configurations are evaluated: a hybrid PV-battery-diesel system inside a local grid and standalone PV-battery systems. Since a local grid requires a certain population density in order to be economical feasible, the population density distribution has been modeled as well. To assess the costeffectiveness the LCOE has been compared with the generation costs of electricity by diesel gensets, which is a common way to generate electricity in these rural areas.

The total technical potential of off-grid PV systems has been estimated to be 969 GWh/year, of which $566 \mathrm{GWh}$ /year generated by local grids (PV-battery-diesel) and 403 GWh/year by stand-alone PV systems (PV-battery). A total nominal power of $816 \mathrm{MW}_{\mathrm{p}}$ PV systems, $321 \mathrm{MW}$ diesel gensets and 8.5 GWh battery capacities has been estimated to be required to achieve $100 \%$ electrification in rural areas. This total capacity of off-grid PV corresponds to just $3 \%$ of the grid-connected PV potential of $28 \mathrm{GW}_{\mathrm{p}}$. Therefore, it would be advisable for Indonesia to focus more on grid-connected PV than the country has done so far.

In most rural parts of Indonesia the LCOE of off-grid PV systems is lower compared with the electricity generation based on diesel gensets with unsubsidized fuel costs. Especially, the hybrid PV configuration - with a LCOE ranging between 0.35 - 0.40 
$\$ / \mathrm{kWh}$ - shows a significant lower LCOE compared with the diesel generated electricity which is in the range of $0.40-0.50 \$ / \mathrm{kWh}$ - for all provinces. However, this hybrid configuration requires a certain population density to be feasible. The LCOE of electricity of the stand-alone PV configuration, which ranges between $0.72-0.79 \$ / \mathrm{kWh}$, is significantly higher. However, electricity generated by diesel is estimated to be more expensive in these areas as well, due to higher transportation cost and less efficient use of the diesel genset the LCOE ranges between $0.67-0.84 \$ / \mathrm{kWh}$. The LCOE of stand-alone $\mathrm{PV}$ is lower in 25 of the 33 provinces of Indonesia. Only in the provinces South and East Kalimantan, Maluku, West Sulawesi, Lampung, Jambi and West Papua standalone PV systems are found to be not cost-effective yet, however in most of these provinces the difference in LCOE is less than $0.01 \$ / \mathrm{kWh}$ and thus on the edge of becoming costeffective.

Overall, both hybrid and standalone PV systems are already cost-effective in large rural parts in Indonesia and it is very likely that this will become the case for all rural areas of Indonesia in the coming years. At the same time, in regions where PV systems are already cost-effective, they will become financially more attractive.

At the system level, the main research question is: What is the performance of a gridconnected PV system in Indonesia? To answer this question, a pilot grid-connected PV system has been installed in Jayapura in the province of Papua. Jayapura regularly suffers from power outages due to aged diesel generators and a weak electricity grid. The performance of the grid-connected PV system in such a weak electricity grid has been evaluated which is new compared with existing experiences in Europe and US and in urbanized areas in Asia.

The $34 \mathrm{~kW}_{\mathrm{p}}$ PV system consists of four PV arrays: Two $12 \mathrm{~kW}$ PV arrays of monocrystalline silicon PV modules, one $7.2 \mathrm{~kW}_{\mathrm{p}}$ PV array of amorphous silicon PV modules and the last PV array consists of twelve mono-crystalline silicon PV modules, each connected to a micro-inverter.

When the PV system is online, it performs well. Overall, it is found that the performances are in line with other PV systems in tropical and Western countries. The performance ratio (PR) of the $7.2 \mathrm{~kW}_{\mathrm{p}}$ PV array is found to be $91 \%$, the two $12 \mathrm{~kW}_{\mathrm{p}} \mathrm{PV}$ arrays perform similar with PRs of $78 \%$ and $79 \%$, and the PV array with the microinverters performs less with a PR of $54 \%$.

Three kinds of energy losses are distinguished, these are the energy losses related to system offline time due to grid instability, to system faults and to the PV module's temperature rise above the standard test conditions (STC) temperature of $25{ }^{\circ} \mathrm{C}$. The energy losses related to grid instability are estimated to be $4 \%$ of the total energy production over a year, which is in the same order of the losses associated with system 
faults. These losses are roughly the half of the energy losses related to the PV modules temperature.

The total estimated energy losses are 6.8 MWh, which corresponds to $16 \%$ of the total annual electricity production.

At the product level, the main research question is: How well do PV power output simulations, based on existing models evaluated for Western climates, perform in Indonesia by applying locally and publicly available weather data?

For this evaluation - a customized tool in the software environment of Quest3D, called VR4PV - has been applied. With VR4PV it is possible to simulate a PV system in a virtual environment, taking shadows from the surroundings into account. To model the shadows, it applies the rasterization principle, which is faster but less accurate than ray tracing techniques. Local weather data can be imported in the tool. An isotropic sky model is applied to translate the global horizontal irradiance to the irradiance in the PV module plane for each time step. Based on the received irradiance and the PV module temperature, the power output is calculated by a one-diode model.

Two data-sets are used to simulate the power output of the PV system, evaluating the appropriateness of existing models for the determination of the power output under tropical weather conditions. One is based on the measured weather variables on site; the other simulation is based on publically available weather data of climatological stations at distances between 650 and $900 \mathrm{~km}$ from the PV system. The former is evaluated at a minutely time scale, the latter at an hourly time scale. The simulated power output is compared with the measured power output.

The simulation based on minutely measured global horizontal irradiance produces reasonable values for the DC power output, the monthly average root-mean-square error (RMSE) is found to be in the range of $350-740 \mathrm{~W}$ for a PV array of $12 \mathrm{~kW}_{\mathrm{p}}$, corresponding to respectively $7 \%$ and $18 \%$ of the monthly average DC power output for the period May 2013 - April 2014.

Due to the distance among the PV system and the weather stations, the hourly simulation of the DC power output based on publicly available irradiance data shows less accurate results, varying between $43 \%$ and $67 \%$ of the monthly average DC power output for the period May 2013 - April 2014. However, these data can be used to determine the total monthly electricity production. Based on hourly measurements covering a year, the relative error is found to be $-2 \%$ of the total measured electricity production. Evaluations per month show a relative error varying between $-16 \%-11 \%$ of the total monthly measured electricity production.

Overall, the RMSE shows fairly low values at medium to high irradiance levels of $8 \%$ which shows that the applied irradiance and temperature models are appropriate to simulate the power output of PV systems in Indonesia. 
Finally, since temperature effects regarding the power output of PV systems play a large role in tropical areas such as Indonesia - corresponding to roughly half of the energy losses based on the studied PV system - the modeling of the PV module temperature has been evaluated in more detail.

To increase the accuracy of short-term PV power output simulations, a new empirical PV module temperature model has been proposed. The proposed model requires four input variables: irradiance received by the PV module, ambient temperature, wind speed and relative humidity. In particular, relative humidity is a new variable for PV module temperature models. Besides, the thermal inertia of the PV module is mimicked by an exponential moving average taken over the prior simulated steady-state PV module temperatures. The model is validated for various PV modules in Jayapura and in Singapore and the results are compared with three existing steady-state empirical models, namely the model of King et al., Skoplaki et al. and the Ross model.

The results show that the proposed model produces accurate results with RMSEs varying between $1.2-2.3{ }^{\circ} \mathrm{C}$, corresponding to $3-6 \%$ of the average PV module temperature for irradiance levels exceeding $50 \mathrm{~W} / \mathrm{m}^{2}$. Compared with the evaluated existing models, this model decreases the RMSE by $1.8{ }^{\circ} \mathrm{C}$ on average for all investigated PV modules in Singapore and Jayapura compared with the second best model, the model of King et al., which corresponds to an improvement of $46 \%$.

Overall, the newly proposed model outperforms the other evaluated empirical models, making it a very suitable model to estimate the PV module temperature on a minute basis when humidity data are available. If relative humidity data are lacking, the proposed exponential moving average would improve the models already significantly for the use at a minutely timescale.

From the results in this thesis can be concluded that PV systems can play an important role to solve many energy related issues in Indonesia. PV systems are already cost-effective in large parts of Indonesia and it is expected that this will count for most other areas as well in the coming years. Besides, it is found that grid-connected PV systems show good performances inside weak grids in Indonesia. Since the potential of grid-connected PV is significant larger compared with standalone PV and grid-connected PV is hardly explored, it should receive more attention in the future. Furthermore, the evaluated models to simulate the power generation of a PV system in Indonesia are found to be appropriate.

Future research on the potential mapping of PV systems could include micro-hydro systems, since they can generate electricity at a lower cost than off-grid PV systems, has been well-developed and has a relatively large potential as well. By including the microhydro resource potential it would be possible to determine the optimal locations for off-grid 
PV projects. For these more detailed maps geographic information systems (GIS) are more suitable.

The grid-connected PV system in Jayapura performs well, however it would be interesting to know the long-term performance of grid-connected PV in Indonesia. The grid quality could impact the lifetime of the various components, which would influence the LCOE.

Future research projects could install and monitor more grid-connected PV systems across Indonesia in order to draw broader conclusions on the performance and lifetime costs of such PV systems in Indonesia. Besides, the interaction with the utility grid and the potential positive effects on the grid quality could be studied more.

The isotropic model applied in this study is relatively simple; more advanced models could be validated to see whether this improves the accuracy of the simulated irradiance. To find the most accurate irradiance transposition model for the application in Indonesia, various models could be evaluated for different locations and tilt angles. 


\section{Samenvatting}

De meer dan 8.000 bewoonde eilanden in Indonesië zorgen ervoor dat de distributie van brandstoffen en elektriciteit een enorme opgave zijn. Het land heeft grote moeite om zowel de elektrificatiegraad te verhogen als om tegelijkertijd tegemoet te komen aan de toenemende vraag naar elektriciteit. Door de overvloed aan zonne-instraling in combinatie met de problemen die geassocieerd worden met rurale elektrificatie, werd Indonesië gezien als een ideale kandidaat voor de vroege aanvaarding van autonome fotovoltaïsche (PV) systemen. In de jaren 90 begonnen veel buitenlandse hulporganisaties met het opzetten van autonome PV projecten in Indonesië. Door verschillende redenen hadden deze projecten een wisselend succes en een aantal faalden om huishoudens adequaat van elektriciteit te voorzien. Echter, de enorme toename van het aantal wereldwijde installaties van hoofdzakelijk netgekoppelde - PV systemen hebben bijgedragen aan kostenverlagingen en de verdere verbeteringen van deze technologie. Daarom zou dit nieuwe kansen kunnen bieden voor Indonesië. Gelijktijdig zorgen de teruglopende voorraden van fossiele brandstoffen en de toenemende bewustwording van klimaatverandering door o.a. $\mathrm{CO}_{2}$ uitstoot ervoor, dat er een klimaat ontstaat waarin PV systemen steeds belangrijker zouden kunnen worden voor de toekomstige elektriciteitsvoorziening van Indonesië. Om deze transitie te stimuleren, is het nodig dat bestaande barrières voor een succesvolle implementatie in kaart gebracht worden, zodat deze weggenomen kunnen worden.

Deze thesis draagt aan deze doelstelling bij door het vergroten van de technische kennis over PV systemen in Indonesië. Dit is bereikt door het modeleren en simuleren van PV systemen. De algemene onderzoeksvraag van deze thesis luidt: Wat kan er geleerd worden van ervaringen met en van het modeleren van PV systemen voor de stimulatie van PV in de toekomstige elektriciteitsmix van Indonesië?

Omdat de succesvolle implementatie van PV systemen van allerlei factoren afhankelijk is, zijn deze systemen geëvalueerd op drie verschillende niveaus, namelijk op het nationale, systeem- en productniveau.

De hoofdonderzoeksvraag op het nationale niveau is: Wat is het potentieel en de kosteneffectiviteit van PV systemen in Indonesië? Om deze vraag te beantwoorden zijn het potentieel en de kosten van PV systemen gemodelleerd en geëvalueerd. Voor deze studie is er een onderscheid gemaakt tussen netgekoppelde en off-grid PV systemen. Vanwege de grote geografische variaties die binnen Indonesië bestaan, zijn de potentiële nominaal geïnstalleerde capaciteit van PV systemen en de genivelleerde kosten van de elektriciteit (LCOE) van deze systemen bepaald voor elke provincie van Indonesië afzonderlijk. Het potentieel is gebaseerd op openbaar beschikbare statistieken en gegevens uit de literatuur. 
Om het potentieel van netgekoppelde PV systemen te bepalen, is elke provincie opgedeeld in vier afzonderlijke gebieden: stadskernen, voorsteden, netgekoppelde landelijke dorpen, en landelijke gebieden zonder elektriciteitsnet. Op basis van de elektrificatie- en urbanisatiegraad is het deel van de bevolking bepaald dat in deze gebieden woonachtig is. Vervolgens is de oppervlakte van elk gebied berekend op basis van gemiddelde bevolkingsdichtheden. Voor elk van deze vier gebieden zijn er aannames gemaakt voor de beschikbaarheid van land voor PV systemen en de opbrengstfactor van deze systemen. In combinatie met de gemiddelde dagelijkse zonne-instraling per provincie is het potentieel voor netgekoppelde PV systemen bepaald.

Om de kosteneffectiviteit te beoordelen is de LCOE vergeleken met de opwekkingskosten van elektriciteit, welke gebaseerd zijn op gegevens van het staatselektriciteitsbedrijf PLN, dat verantwoordelijk is voor de distributie van elektriciteit in Indonesië.

Op basis van deze studie kan geconcludeerd worden dat het totale technische potentieel van netgekoppelde PV systemen in Indonesië grofweg 1,100 GW $\mathrm{GW}_{\mathrm{p}}$ is, die ongeveer 1,490 TWh per jaar aan elektriciteit kunnen leveren. Dit is tien keer meer dan het elektriciteitsverbruik in Indonesië in 2010.

Als rekening gehouden wordt met beperkingen ten aanzien van de elektriciteitsproductie, door alleen de elektriciteitsvraag gedurende de dag en een minimale basislast voor conventionele elektriciteitscentrales mee te nemen, wordt het totale potentieel logischerwijs lager, namelijk ongeveer $28 \mathrm{GW}_{\mathrm{p}}$, die $37 \mathrm{TWh}$ per jaar leveren, wat overeenkomt met ongeveer 25\% van het totale elektriciteitsverbruik in Indonesië in 2010. Vergeleken met het potentieel van andere duurzame energie bronnen in Indonesië, is het huidige begrensde potentieel voor netgekoppelde PV systemen vergelijkbaar met het potentieel van geothermische energie, ongeveer de helft van het potentieel van biomassa en ongeveer drie keer het potentieel van wind energie.

De geschatte LCOE van netgekoppelde PV systemen variëren tussen de 0,15 en 0,24 $\$ / \mathrm{kWh}$ en deze systemen zijn hiermee al kosteneffectief in de provincies van WestKalimantan, Noord-Molukken, Molukken, West- en Oost-Nusa Tenggara, Banka-Billiton, West-Papoea en Papoea. Daarnaast is de verwachting dat dit in de nabije toekomst ook zal gelden voor de provincies van Kalimantan, Celebes, West- en North-Sumatra, Riau, Riouwarchipel en Atjeh.

De evaluatie van het potentieel voor off-grid PV systemen richt zich op huishoudens in landelijke gebieden met gebrek aan toegang tot elektriciteit. Twee configuraties voor offgrid PV systemen zijn beoordeeld: een hybride PV-batterij-diesel systeem binnen een lokaal elektriciteitsnet en autonome PV-batterij systemen.

Omdat een lokaal net een bepaalde bevolkingsdichtheid nodig heeft om economisch haalbaar te zijn, is tevens de bevolkingsdistributie gemodelleerd. Om de kosteneffectiviteit 
te beoordelen is de LCOE vergeleken met de opwekkingskosten van elektriciteit van dieselgeneratoren, wat een gebruikelijke manier is om elektriciteit op te wekken in deze afgelegen gebieden.

Het totale technische potentieel voor off-grid PV systemen is geschat op $969 \mathrm{GWh} / \mathrm{jaar}$, waarvan $566 \mathrm{GWh} /$ jaar gegenereerd wordt in lokale elektriciteitsnetten (PV-batterij-diesel) en $403 \mathrm{GWh} /$ jaar met autonome PV systemen (PV-batterij). Een totale nominale capaciteit van $816 \mathrm{MW}_{\mathrm{p}}$ PV systemen, $321 \mathrm{MW}$ diesel generatoren en $8.5 \mathrm{GWh}$ aan batterijcapaciteit is nodig om $100 \%$ elektrificatie te verkrijgen in de landelijke gebieden.

Deze totale capaciteit aan off-grid PV komt overeen met maar 3\% van het potentieel voor netgekoppelde PV systemen van $28 \mathrm{GW}_{\mathrm{p}}$. Daarom zou het voor Indonesië raadzaam zijn om zich meer te richten op netgekoppelde PV dan het land tot dusver heeft gedaan.

In de meeste landelijke gebieden van Indonesië is de LCOE van off-grid PV systemen lager vergeleken met de elektriciteit die opgewekt wordt door diesel generatoren, gebaseerd op ongesubsidieerde brandstofkosten. Met name de hybride configuratie, met een LCOE variërend tussen de $0,35-0,40 \$ / \mathrm{kWh}$, laat een significant lagere LCOE zien vergeleken met de door diesel opgewekte elektriciteit, waarvan de kosten tussen de 0,40 - 0,50\$/kWh bedragen voor alle provincies. Echter, deze hybride variant vereist een zekere bevolkingsdichtheid om het economisch rendabel te maken. De LCOE van de elektriciteit voor de autonome PV configuratie, die varieert tussen de $0,72-0,79 \$ / \mathrm{kWh}$, is significant hoger. Maar, er is aangenomen dat de kosten van elektriciteitsopwekking d.m.v. dieselgeneratoren in deze gebieden ook duurder zijn, door hogere transportkosten en een minder efficiënt gebruik van de generatoren wordt de LCOE hiervan geschat tussen de 0,67 $-0,84 \$ / \mathrm{kWh}$.

De LCOE van autonome PV is lager in 25 van de 33 provincies van Indonesië. Alleen in de provincies Zuid- en Oost-Kalimantan, Molukken, West-Celebes, Lampung, Jambi en West-Papoea zijn autonome PV systemen nog niet kosteneffectief bevonden, echter in de meeste van deze provincies is het verschil in LCOE minder dan $0,01 \$ / \mathrm{kWh}$ en dus op de rand om kosteneffectief te worden.

In het algemeen geldt dat zowel de hybride als de autonome PV systemen al kosteneffectief zijn in grote delen van de landelijke gebieden in Indonesië en hoogstwaarschijnlijk zal dit in de komende jaren ook het geval gaan worden voor de overige in Indonesië. Tegelijkertijd worden deze PV systemen financieel aantrekkelijker in de regio's waar deze nu al kosteneffectief zijn.

De hoofdonderzoeksvraag op systeemniveau is: Wat is de opbrengst van een netgekoppeld PV systeem in Indonesië? Om deze vraag te beantwoorden is er in Jayapura in de provincie Papoea een netgekoppeld PV systeem geïnstalleerd. Jayapura heeft regelmatig last van stroomuitvallen door verouderde dieselgeneratoren en door een zwak 
elektriciteitsnet. De opbrengst van een netgekoppeld PV systeem in een zwak net is geëvalueerd, wat nieuw is vergeleken met bestaande ervaringen in Europa en de VS en in stedelijke gebieden in Azië.

Het $34 \mathrm{~kW}_{\mathrm{p}}$ PV systeem bestaat uit vier PV arrays: Twee $12 \mathrm{~kW}_{\mathrm{p}}$ PV arrays met monokristallijn silicium zonnepanelen, een $7,2 \mathrm{~kW}_{\mathrm{p}} \mathrm{PV}$ array met amorfe silicium zonnepanelen en de laatste array bestaat uit twaalf monokristallijn silicium zonnepanelen, elk verbonden met een eigen micro-omvormer.

Als het PV systeem online is, presteert het goed. In het algemeen geldt dat de opbrengstfactoren overeenkomen met andere PV systemen in tropische en Westerse landen.

De opbrengstfactor, ook wel performance ratio (PR) genoemd, van de 7,2 kW $\mathrm{PV}$ array is $91 \%$, de twee $12 \mathrm{~kW}_{\mathrm{p}}$ PV arrays presteren overeenkomstig met PRs van $78 \%$ en $79 \%$, en de PV array met de micro-omvormers presteert minder goed met een PR van 54\%.

Drie soorten energieverliezen zijn te onderscheiden, dit zijn de energieverliezen door de offline tijd van het systeem door instabiliteit van het elektriciteitsnet, door systeemfouten en door de temperatuursverhoging van de zonnepanelen boven de temperatuur van de standaard test condities (STC) van $25^{\circ} \mathrm{C}$. De energieverliezen gerelateerd aan de instabiliteit van het net bedragen ongeveer $4 \%$ van de totale jaarlijkse energieopbrengst, wat in dezelfde orde van grootte is als de verliezen die geassocieerd kunnen worden met systeemfouten. Deze verliezen zijn grofweg de helft van de energieverliezen door de temperatuurverhoging van de zonnepanelen.

De totale energieverliezen bedragen 6,8 MWh, wat overeenkomt met $16 \%$ van de totale jaarlijkse elektriciteitsproductie van het PV systeem.

De hoofdonderzoeksvraag op het productniveau is: Hoe goed presteren de simulaties voor de vermogensafgifte van PV panelen, gebaseerd op bestaande modellen die geëvalueerd zijn in landen met een hogere breedtegraad, als lokale en openbaar beschikbare weersgegevens gebruikt worden?

Voor deze studie is een aangepaste softwaretool binnen de softwareomgeving van Quest3D, VR4PV genaamd, toegepast. Met VR4PV is het mogelijk om een PV systeem te simuleren in een virtuele omgeving, waarbij er rekening gehouden kan worden met schaduwen door nabijgelegen objecten. Om deze schaduwen te modelleren, wordt er binnen de VR4PV gebruik gemaakt van het rasterisatie principe, wat sneller maar minder nauwkeurig is dan ray-tracing.

Weersgegevens kunnen geïmporteerd worden in de VR4PV. Een isotroop model is toegepast om de globale horizontale instraling te vertalen naar de instraling in het vlak van het zonnepaneel. Op basis van de ontvangen instraling en de temperatuur van het zonnepaneel wordt het uitgangsvermogen bepaald d.m.v. een één-diode-model. 
Twee datasets zijn gebruikt voor de simulatie van de vermogensafgifte van het PV systeem, om de geschiktheid van bestaande modellen te beoordelen voor het bepalen van de vermogensafgifte onder tropische weersomstandigheden. De eerste is gebaseerd op metingen op de plek van het PV systeem zelf, de tweede dataset is gebaseerd op openbaar beschikbare weersgegevens van klimatologische meetstations op een afstand tussen de 650 en $900 \mathrm{~km}$ van het PV systeem. De simulatie gebaseerd op eerste dataset is beoordeeld op een minuutbasis, voor de andere dataset is een tijdsinterval van een uur toegepast.

De simulatie gebaseerd op de globale horizontale instraling per minuut geeft redelijke resultaten voor de gelijkstroom (DC) vermogensafgifte. De maandelijkse gemiddelde rootmean-square-error (RMSE) varieert tussen de 350 - $740 \mathrm{~W}$ voor een PV array van $12 \mathrm{~kW}$, wat overeenkomt met respectievelijk $7 \%$ en $18 \%$ van de maandelijkse gemiddelde DC vermogensafgifte voor de periode van mei 2013 - april 2014.

Door de afstand tussen de meetlocaties en het PV systeem, laat de uurlijkse simulatie van het DC vermogen gebaseerd op openbaar beschikbare instraling minder nauwkeurige resultaten zien, variërend tussen $43 \%$ en $67 \%$ van de maandelijkse gemiddelde DC vermogensafgifte voor de periode van mei 2013 - april 2014. Echter, deze gegevens zouden gebruikt kunnen worden om de totale maandelijkse elektriciteitsproductie te bepalen. Gebaseerd op de uurlijkse metingen gedurende een jaar, is de relatieve fout voor de totale gemeten elektriciteitsproductie $-2 \%$, maar op maandbasis varieert deze fout tussen de $-16 \%$ - $11 \%$ van de totale maandelijkse gemeten energieopbrengst.

In het algemeen geldt dat de simulaties redelijk lage RMSE waarden geeft voor gemiddelde tot hoge bestralingssterkten, wat laat zien dat de toegepaste instralings- en temperatuurmodellen geschikt zijn voor simulaties van het vermogen van PV systemen in Indonesië.

Als laatste, omdat temperatuureffecten met betrekking op de vermogensafgifte van PV systemen een grotere rol spelen in tropische gebieden zoals Indonesië - verantwoordelijk voor ongeveer de helft van de energieverliezen in het bestudeerde PV systeem - en omdat tijdens simulaties is gebleken, dat het toegepaste temperatuurmodel ongeschikt is voor tijdsintervallen van een minuut, is de modelering van de temperatuur van een zonnepaneel verder onderzocht.

Om de nauwkeurigheid van de simulaties van de vermogensafgifte van PV systemen te vergroten, is er een nieuw empirisch model ontwikkeld. Het ontwikkelde model benodigd vier ingangsvariabelen: de instraling ontvangen door het zonnepaneel, de omgevingstemperatuur, de windsnelheid en de relatieve luchtvochtigheid. Vooral de relatieve luchtvochtigheid is een nieuwe variabele voor temperatuurmodellen voor PV panelen. Daarnaast is de thermische inertie van een PV paneel gesimuleerd door een exponentieel bewegend gemiddelde te bepalen over de voorgaande gesimuleerde steady- 
state temperaturen van het zonnepaneel. Het model is gevalideerd voor verschillende PV panelen in Jayapura en in Singapore en de resultaten zijn vergeleken met drie bestaande empirische steady-state modellen, namelijk het model van King et al., Skoplaki et al. en het Ross model.

De validatie laat zien dat het nieuw ontwikkelde model nauwkeurige resultaten oplevert met RMSEs variërend tussen de $1,2-2,3{ }^{\circ} \mathrm{C}$, overeenkomend met 3-6\% van de gemiddelde temperatuur van het PV paneel voor bestralingssterktes groter dan $50 \mathrm{~W} / \mathrm{m}^{2}$. Vergeleken met de andere bestudeerde modellen, verlaagt dit model de RMSE met gemiddeld $1,8{ }^{\circ} \mathrm{C}$ voor alle onderzochte PV panelen in Singapore en Jayapura vergeleken met het op een na beste model, het model van King et al., wat overeenkomt met een verbetering van $46 \%$.

In het algemeen presteert het ontwikkelde model beter dan de andere bestudeerde empirische modellen, daarom is dit model erg geschikt om de temperatuur van een PV model te bepalen op een minuutbasis wanneer gegevens over de relatieve luchtvochtigheid bekend zijn. Als dit laatste niet het geval is, dan kan het voorgestelde exponentieel bewegend gemiddelde al voor een significante verbetering zorgen voor gebruik op minuutbasis.

Op basis van de resultaten van deze thesis kan geconcludeerd worden dat PV systemen een belangrijke rol kunnen vervullen om veel energie-gerelateerde problemen in Indonesië op te lossen. PV systemen zijn al kosteneffectief in grote delen van Indonesië en de verwachting is dat dit ook voor de overige gebieden zal gelden in de komende jaren. Daarnaast is gebleken dat netgekoppelde PV systemen goed presteren in zwakke elektriciteitsnetten in Indonesië. Omdat het potentieel voor netgekoppelde PV significant groter is vergeleken met autonome PV, en netgekoppelde PV nog weinig verkend is in Indonesië, zou dit meer aandacht moeten krijgen in de toekomst. Verder is gebleken dat de bestudeerde modellen om de vermogensafgifte van PV systemen te simuleren geschikt zijn voor gebruik in Indonesië.

Voor het in kaart brengen van het potentieel voor PV systemen zou toekomstig onderzoek ook micro-hydro systemen kunnen meenemen, omdat de op deze manier opgewekte elektriciteit lagere kosten met zich meebrengt dan de huidige off-grid PV systemen, de technologie ver ontwikkeld is en het ook een relatief groot potentieel in Indonesië heeft. Met deze benadering zouden de optimale locaties voor off-grid PV projecten bepaald kunnen worden. Omdat het potentieel van micro-hydro meer locatieafhankelijk is, zou een geografisch informatie systeem (GIS) hiervoor meer geschikt zijn. 
Het netgekoppelde PV systeem in Jayapura presteert goed, maar het zou interessant zijn om ook de lange termijn prestaties van netgekoppelde PV in Indonesië te onderzoeken. De kwaliteit van het elektriciteitsnet zou de levensduur van verschillende componenten kunnen beïnvloeden, wat uiteindelijk ook zijn uitwerking heeft op de LCOE.

Toekomstige onderzoeksprojecten zouden meer netgekoppelde PV systemen verspreid over Indonesië kunnen installeren en monitoren om bredere conclusies te kunnen trekken wat betreft de prestaties en levensduurkosten van zulke PV systemen. Daarnaast is de interactie met het elektriciteitsnet en de potentiële positieve effecten op de kwaliteit van dit net een interessant onderwerp om verder te onderzoeken.

Het isotrope model dat toegepast is in deze thesis voor de berekening van de instraling is relatief simpel, meer complexe modellen zouden gevalideerd kunnen worden om te zien of de nauwkeurigheid van de gesimuleerde instraling hiermee verbeterd.

Om het meest nauwkeurige transpositie model te vinden voor gebruik in Indonesië, zouden verschillende modellen geëvalueerd kunnen worden voor verschillende locaties en hellingshoeken. 


\section{Table of contents}

Preface $\quad$ vi

Summary $\quad$ ix

$\begin{array}{ll}\text { Samenvatting } & \text { xv }\end{array}$

Table of contents $\quad$ vi

List of symbols and abbreviations viii

1. Introduction 1

1.1 PV systems in Indonesia 3

1.2 Problem definition 5

1.3 Context of PV system research 6

$\begin{array}{lll}1.4 & \text { Research plan } & 10\end{array}$

1.5 Thesis outline 11

2. Energy supply in Indonesia $\quad \mathbf{1 3}$

2.1 Challenges due to population growth, increased wealth and dispersed islands $\quad 15$

2.2 Renewable energy resources in Indonesia 22

2.3 Energy scenario study 25

2.4 Monitoring of PV systems 26

2.5 Modeling and simulation of PV systems 28

2.6 Research questions and setup of thesis 30

3. The potential and costs of grid-connected PV systems in Indonesia 31

3.1 Introduction 33

3.2 Modeling the potential of grid-connected PV 34

3.3 Grid-connected PV potential and costs 46

3.4 Model limitations 53

3.5 Conclusions 53

4. The potential and costs of off-grid PV systems in Indonesia 55

4.1 Introduction $\quad 57$

4.2 Modeling the potential of off-grid PV systems 58

$\begin{array}{lll}4.3 & \text { Off-grid PV potential and costs } & 71\end{array}$

$\begin{array}{lll}4.4 & \text { Comparison with existing off-grid PV projects } & 76\end{array}$

4.5 Limitations of the off-grid PV model $\quad 80$

4.6 Conclusions $\quad 82$ 
5. The performance of a grid-connected PV system in Jayapura

$\begin{array}{lll}5.1 & \text { Introduction } & 87\end{array}$

$\begin{array}{llr}5.2 & \text { System description } & 88\end{array}$

5.3 Performance of the PV system 93

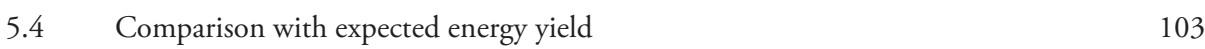

$\begin{array}{lll}5.5 & \text { Conclusions } & 103\end{array}$

6. Simulating the PV power generation in a virtual environment 105

$\begin{array}{lll}6.1 & \text { Introduction } & 107\end{array}$

$\begin{array}{ll}\text { 6.2 Simulation approach and input data } & 109\end{array}$

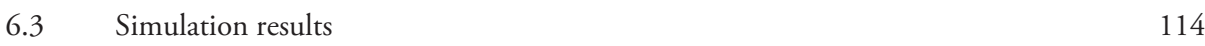

6.4 Discussion of the simulation results 124

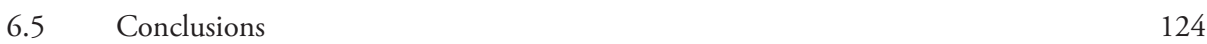

7. Simulation of the PV module temperatures at small time scales $\quad 127$

$\begin{array}{lll}7.1 & \text { Introduction } & 129\end{array}$

$\begin{array}{lll}7.2 & \text { The proposed model } & 132\end{array}$

$\begin{array}{lll}7.3 & \text { Weather data and experimental setup } & 133\end{array}$

$\begin{array}{lll}7.4 & \text { The accuracy of the various PV temperature models } & 141\end{array}$

$\begin{array}{lll}7.5 & \text { Discussion of the proposed model } & 146\end{array}$

$\begin{array}{lll}7.6 & \text { Conclusions } & 147\end{array}$

8. Reflection $\quad 149$

8.1 Macro-level: PV potential study 151

8.2 Meso-level: Grid-connected PV system in Jayapura 153

8.3 Micro-level: Simulation of the PV power generation 154

$\begin{array}{lll}8.4 & \text { General } & 155\end{array}$

9. Conclusions and recommendations 157

9.1 The potential and cost-effectiveness of PV systems 159

9.2 The performance of the PV system in Jayapura 162

9.3 Simulation of the power generation of PV systems 162

9.4 PV temperature modeling 163

$\begin{array}{ll}\text { 9.5 Directions for future research } & 164\end{array}$

$\begin{array}{ll}\text { Bibliography } & 166\end{array}$

$\begin{array}{ll}\text { Publications } & 175\end{array}$

$\begin{array}{ll}\text { Appendices } & 177\end{array}$

$\begin{array}{ll}\text { A. Illegal electricity consumption in Indonesia } & 178\end{array}$

B. Details PV system Jayapura 182

C. Monthly performance of the PV system in Jayapura 184

D. VR4PV software in Quest3D 214 


\section{List of symbols and}

\section{abbreviations}

\begin{tabular}{|c|c|c|}
\hline \multicolumn{3}{|c|}{ Symbols } \\
\hline Symbol & Meaning & Unit \\
\hline A & area & $\mathrm{km}^{2}$ \\
\hline $\mathrm{AO}$ & annual operation costs & $\$$ \\
\hline $\mathrm{A}_{\mathrm{p}, 0.8}$ & $80 \%$ of the total land area of province $p$ & $\mathrm{~km}^{2}$ \\
\hline $\mathrm{BF}$ & PV system availability factor & $\%$ \\
\hline $\mathrm{C}$ & nominal capacity & W \\
\hline CAPEX & capital expenditures & $\$$ \\
\hline $\mathrm{C}_{\text {batt }}$ & battery capacity & $\mathrm{kWh}$ \\
\hline $\mathrm{CF}$ & capacity factor & $\%$ \\
\hline d & days & $\mathrm{d}$ \\
\hline doa & days of autonomy & $\mathrm{d}$ \\
\hline DOD & depth of discharge & $\%$ \\
\hline DP & annual depreciation & $\$$ \\
\hline DR & discount rate & $\%$ \\
\hline E & energy & $\mathrm{kWh} / \mathrm{GWh}^{1}$ \\
\hline $\mathrm{EF}$ & $\mathrm{CO}_{2}$ grid emission factors & ton $\mathrm{CO}_{2}$-eq $/ \mathrm{MWh}_{\mathrm{c}}$ \\
\hline $\mathrm{E}_{\mathrm{FI}}$ & $\begin{array}{l}\text { AC energy fed into the grid based on measurements from the } \\
\text { WebBox }\end{array}$ & $\mathrm{kWh}$ \\
\hline $\mathrm{E}_{\mathrm{LT}}$ & DC energy lost due to the temperature effect & $\mathrm{kWh}$ \\
\hline ER & electrifcation ratio & $\%$ \\
\hline G & global irradiance & $\mathrm{W} / \mathrm{m}^{2}$ \\
\hline Gstc & global irradiance at standard test conditions & $\mathrm{W} / \mathrm{m}^{2}$ \\
\hline Ghor & global horizontal irradiance & $\mathrm{W} / \mathrm{m}^{2}$ \\
\hline $\mathrm{G}_{\mathrm{m}}$ & global irradiance in plane of PV module & $\mathrm{W} / \mathrm{m}^{2}$ \\
\hline $\mathrm{H}$ & irradiation & $\mathrm{kWh} / \mathrm{m}^{2}$ \\
\hline h & convective heat transfer coefficient & - \\
\hline $\mathrm{HH}$ & number of households & households \\
\hline
\end{tabular}

${ }^{1}$ In Chapter 3 and 4, the values are in GWh 


\begin{tabular}{|c|c|c|}
\hline $\mathrm{H}_{\mathrm{i}, \mathrm{u}}$ & irradiation in plane of PV array & $\mathrm{kWh}$ \\
\hline $\mathrm{hr}$ & hours & $\mathrm{h}$ \\
\hline I & current & A \\
\hline $\mathrm{k}$ & Ross coefficient & ${ }^{\circ} \mathrm{C} \cdot \mathrm{m}^{2} / \mathrm{W}$ \\
\hline LA & land availability factor for grid-connected PV & $\%$ \\
\hline LCOE & levelized cost of electricity & $\$ / \mathrm{kWh}$ \\
\hline $\mathrm{LT}$ & lifetime & years \\
\hline MF & monitoring fraction & $\%$ \\
\hline $\mathrm{N}$ & population & persons \\
\hline ND & population density & persons $/ \mathrm{km}^{2}$ \\
\hline $\mathrm{P}$ & power & W \\
\hline parm & atmospheric pressure & $\mathrm{Pa}$ \\
\hline PR & performance ratio & $\%$ \\
\hline rain & rainfall & $\mathrm{mm}$ \\
\hline $\mathrm{RH}$ & relative humidity & $\%$ \\
\hline RV & residual value of the PV system after its lifetime & $\$$ \\
\hline RVR & residual value rate & $\%$ \\
\hline SDR & system degradation rate & $\%$ \\
\hline $\mathrm{t}$ & temperature lag time & $\min$ \\
\hline $\mathrm{T}_{\mathrm{a}}$ & ambient temperature & ${ }^{\circ} \mathrm{C}$ \\
\hline $\mathrm{T}_{\mathrm{m}}$ & PV module's back-surface temperature & ${ }^{\circ} \mathrm{C}$ \\
\hline TR & tax rate & $\%$ \\
\hline $\mathrm{T}_{\mathrm{r}}$ & part of the PV module temperature due to radiative heat transfer & ${ }^{\circ} \mathrm{C}$ \\
\hline UR & urbanization rate & $\%$ \\
\hline $\mathrm{V}$ & voltage & $\mathrm{V}$ \\
\hline $\mathrm{v}_{\mathrm{w}}$ & average wind speed & $\mathrm{m} / \mathrm{s}$ \\
\hline$\alpha$ & share of the electricity demand which is generated by PV & - \\
\hline$\gamma$ & humidity coefficient & - \\
\hline$\Delta \mathrm{T}_{\mathrm{rc}}$ & temperature difference due to radiative cooling & ${ }^{\circ} \mathrm{C}$ \\
\hline$\eta$ & efficiency & $\%$ \\
\hline$\eta_{\mathrm{sys}}$ & system efficiency & $\%$ \\
\hline$\eta_{\text {wires }}$ & wires efficiency & $\%$ \\
\hline$\theta$ & wind direction & $\circ$ \\
\hline$\lambda$ & exponential wind factor & - \\
\hline$\lambda_{\mathrm{ND}}$ & rate of decline in population density over distance & - \\
\hline
\end{tabular}




\section{Subscripts}

\begin{tabular}{|c|c|}
\hline Symbol & Meaning \\
\hline()$_{\mathrm{A}}$ & PV array \\
\hline()$_{\mathrm{ac}}$ & alternating current \\
\hline ( ) batt & battery \\
\hline()$_{\mathrm{C}}$ & per capacity \\
\hline()$_{\text {cap }}$ & per capita \\
\hline()$_{\mathrm{ctrl}}$ & charge controller \\
\hline()$_{\mathrm{d}}$ & per day \\
\hline ( ) daytime & during daytime \\
\hline()$_{\mathrm{dc}}$ & direct current \\
\hline ( ) demand & electricity demand \\
\hline()$_{\mathrm{DG}}$ & diesel genset \\
\hline()$_{\mathrm{DL}}$ & based on measurements from the data logger \\
\hline$($ ) $\mathrm{dsl}$ & diesel \\
\hline ( ) EMA & exponential moving average \\
\hline()$_{\mathrm{gc}}$ & grid-connected \\
\hline()$_{\mathrm{h}}$ & high demand category \\
\hline ( ) HH $_{\mathrm{H}}$ & per household \\
\hline()$_{\mathrm{i}}$ & Area type ( $\mathrm{i}=1$ : urban core, $\mathrm{i}=2$ : suburban, $\mathrm{i}=3$ : grid-connected rural village, $\mathrm{i}=4$ : rural area) \\
\hline()$_{\text {inv }}$ & inverter \\
\hline()$_{1}$ & low demand category \\
\hline()$_{\mathrm{L}}$ & load \\
\hline()$_{\lg }$ & local grid \\
\hline()$_{\max }$ & maximum \\
\hline()$_{\min }$ & minimum \\
\hline()$_{\mathrm{ND}}$ & population density \\
\hline ( ) night & during nighttime \\
\hline()$_{\mathrm{p}}$ & province \\
\hline()$_{\text {pot }}$ & potential \\
\hline ( ) PV & PV system \\
\hline()$_{\mathrm{sa}}$ & stand-alone \\
\hline ( ) & based on measurements from the WebBox \\
\hline()$_{y}$ & per year \\
\hline
\end{tabular}




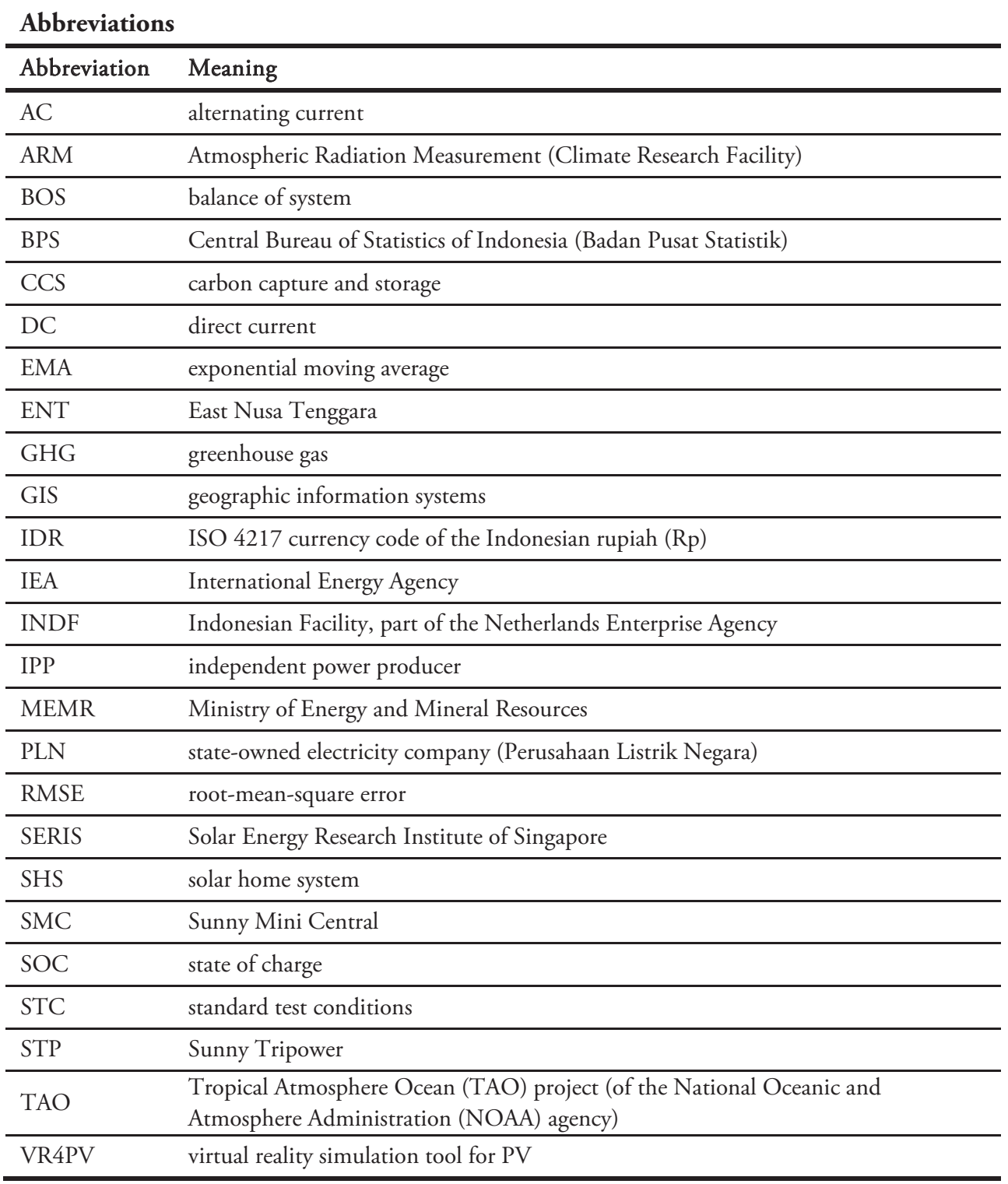





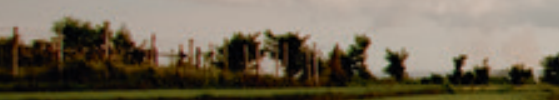

Whom

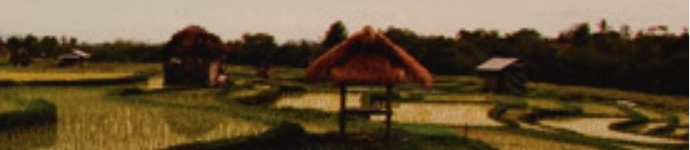

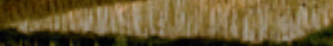

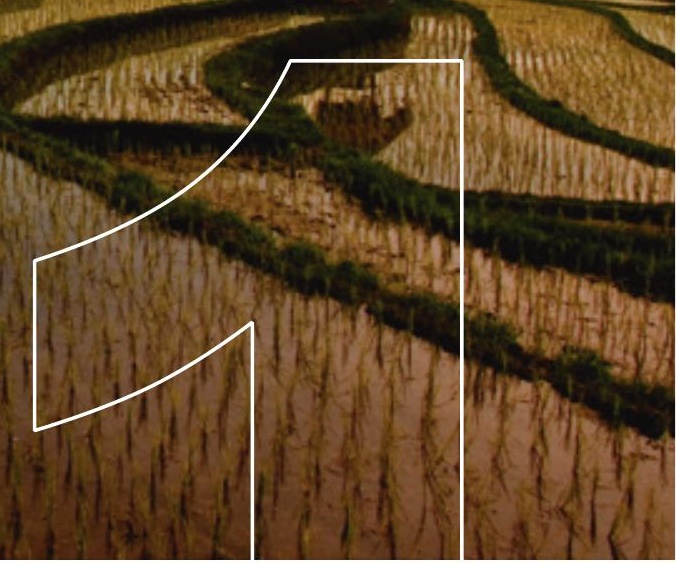

\section{Introduction}




\section{Introduction}

\subsection{PV systems in Indonesia}

Indonesia has a long history with off-grid photovoltaic (PV) systems in remote locations. The specific circumstances of these areas which lacked grid electricity created a demand for other forms of electricity supply. The first off-grid PV application in Indonesia was a $5 \mathrm{~kW}_{\mathrm{p}}$ PV water pumping system in 1978 [2]. In 1979 R\&D activities funded by the German government aimed to use solar energy to cover basic needs of a specific village. In coastal areas, PV systems were applied for the desalination of sea water to get drinking water, for ice production to preserve fish and to light navigational buoys [3]. The projects ran until 1984 and continued from 1985 - 1996, including other applications such as medical refrigerators, remote TVs and direct pumping systems for remote villages [3].

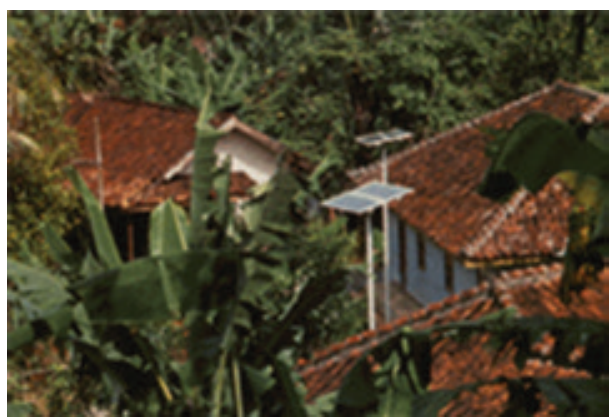

Fig. 1.1. Solar Home System in Sukatani, Indonesia [1].

During the same period various other demonstration programs have been initiated, such as the Village Electrification Pilot Project in cooperation with Japan in Kenteng, Yogyakarta in 1978 [4]. In the same year, Solar Home Systems (SHS) were provided in cooperation with the Dutch government for the village of Sukatani, West Java (Fig. 1.1). The systems consisted of $80 \mathrm{~W}_{\mathrm{p}}$ SHSs and were meant for powering lights in order to replace kerosene candles [1,3]. After the success of the Sukatani project, roughly 3,400 $50 \mathrm{~W}_{\mathrm{p}} \mathrm{SHS}$ for 15 provinces were funded by the President Aid Project in 1990 [3, 4].

In 1991, similar to the Sukatani project, five hundred SHSs were installed in the district of Lebak, West Java, financially supported by the Dutch province of North Holland and its provincial electricity company PEN [1].

Due to the success of the demonstration projects, these were followed by large dissemination programs by the Indonesian government such as the $50 \mathrm{MW}_{\mathrm{p}}$ "One Million Rural Solar Home System Program” announced in 1991 and launched in 1994 [1, 3]. The 
first phase was funded by AUSAID, the World Bank and BIG-SOL and by the end of 1999 over 36,000 SHS and some hybrid PV systems have been installed within this program [3, 4]. It has been estimated that roughly 80,000 SHS were installed in Indonesia early 2000 [5]. Around that time the budget from Indonesian government stopped and the 50MWp program also terminated; however, from 2004 - 2007 an additional amount of 80,000 SHSs has been installed [3].

In 2003 the first urban PV program was launched by the Ministry of Energy and Mineral Resources (MEMR) [6], however grid-connected PV systems are still in the research and demonstration phase in Indonesia. Early 2009 the total amount of grid-connected PV is roughly $112 \mathrm{~kW}_{\mathrm{p}}$ distributed over four locations [3].

Especially for large PV systems, most of the PV components are still imported; for smaller systems - such as a SHS - only the PV modules are imported, the rest is produced locally [3]. Indonesia lacks production capacity for PV modules, which can also be perceived from Fig. 1.2 in which Indonesia is compared with neighboring countries.

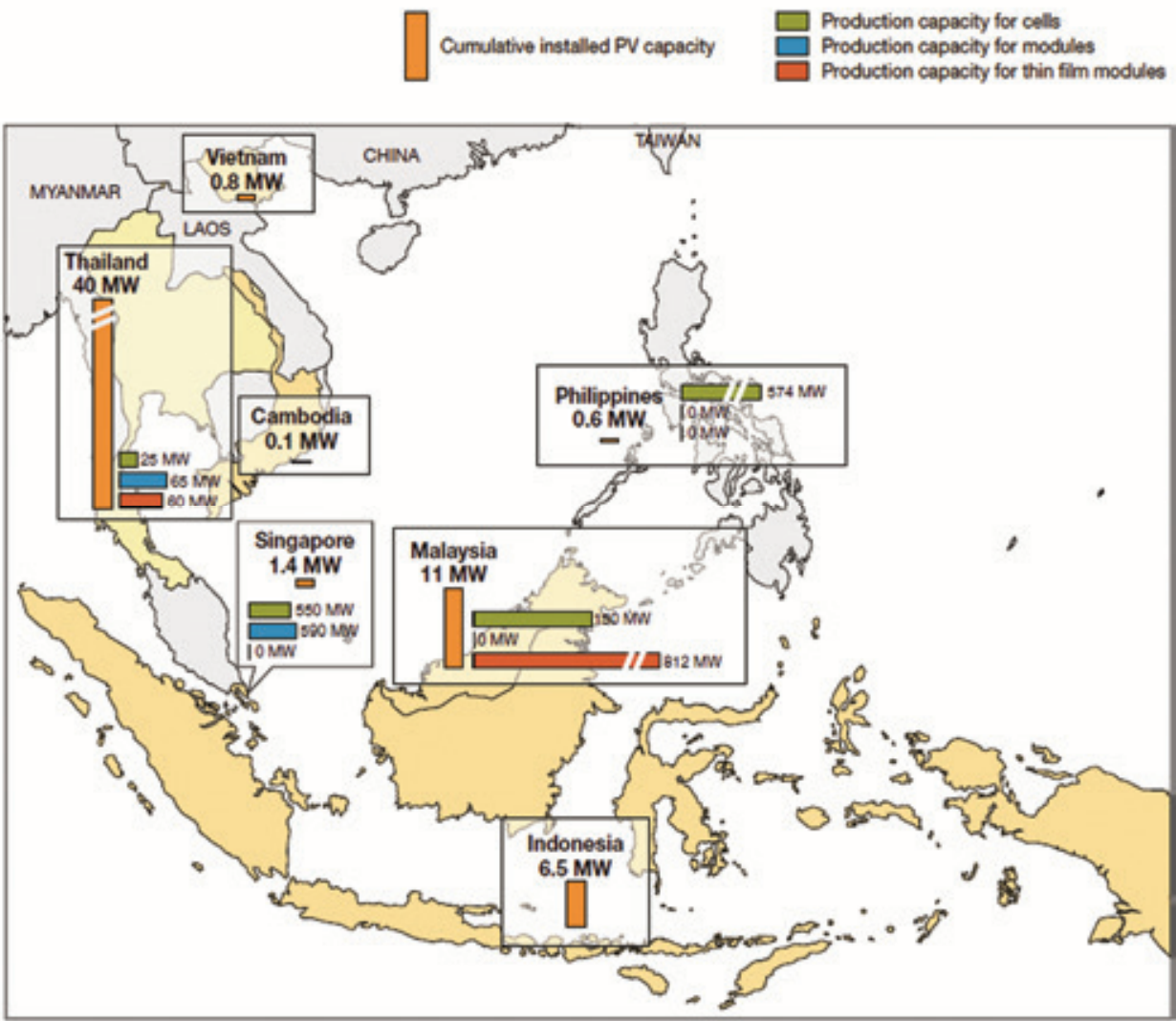

Fig. 1.2. Installed and production capacities for PV for Southeast Asia in 2011, source: A.T. Kearney analysis [7]. 


\subsection{Problem definition}

Although the potential of solar energy in Indonesia has often been mentioned, based on present energy projections, it can be concluded that till recently it was not perceived as an important energy source to contribute significantly to Indonesia's future energy mix. PV is still perceived as an expensive energy source, mainly suitable for small to medium sized offgrid applications [7]. This has several reasons. The experience Indonesia has with PV systems is mainly related to the Solar Home Systems (SHS) installed in the previous decades, which are mostly installed in remote locations to supply electricity for lighting to rural households. Although the SHS-programs were relatively successful because of the systematic and integrated approach [8], these programs had varying degrees of success and some failed to supply adequate electricity to households for a number of reasons [5, 9]. Early SHSs failed because of a unreliable technical performance, lack of on-going qualified technical support, poor attention to cost recovery and unrealized user expectations [9].

Regarding the technical performance of the early SHSs, batteries and fluorescent lights caused most technical problems; PV modules were found to be the least problematic component of SHSs [5]. Therefore, high quality and well-designed PV systems are found to be essential for the success of SHSs [5, 9]. Due to technical standards, most technical issues regarding SHSs have been solved in the meantime [3].

Insufficient training and technical support was offered to the local communities, resulting in a lack of maintenance and consequently unsustainable projects $[3,5,8,9]$, which is related to the struggling of PV dealers to achieve economies of scale in many remote communities [8]. Also the knowhow of the user is important. For example, if a lamp gets broken, the user considers often the whole system as damaged [5]. However, the attitude of islanders to PV systems is found to be mostly positive [10].

At the same time, the Indonesian state-owned utility firm PLN (Perusahaan Listrik Negara) engaged in generation, transmission and distribution of electricity experiences some barriers to extend its service to remote areas. Since PLN has mainly expertise in the development of grid-connected systems, alternative solutions struggle to find a place within PLN's structure [8]. Moreover, the generation cost of PLN in remote areas is significantly higher, but PLN is not allowed to differentiate in tariff [8]. In combination with the huge amounts of cheap coal, the potential of large-scale PV systems has not been explored well. In addition, because of the lacking PV industry in Indonesia, investments in this technology will not directly support the national economy. However, with declining costs of PV systems, the global installations of - mainly grid-connected - PV systems have increased tremendously in past years, contributing to the maturing of the technology [7, 11, 12]. Therefore, grid-connected PV systems could offer new opportunities in areas where off-grid PV systems are not cost-effective, such as urban areas. 
In these areas, grid-connected PV can offer various advantages, such as reduction of distribution losses, improvements of the quality and continuity of electricity supply and reduction of the required generation capacity due to peak-shaving [13]. At the same time, urban grid-connected PV systems could provide a way to create a stable PV market and stimulate the national PV business.

Moreover, the geographic situation of Indonesia, depleting fossil energy resources and the increasing awareness of climate change due to the $\mathrm{CO}_{2}$ emissions of fossil fuels, create an environment wherein PV systems could become increasingly important for the future electricity mix of Indonesia.

This thought is supported at present by the Ministry of Energy and Mineral Resources (MEMR) of the Indonesian government noting that the PV potential has not been mapped yet and projecting a $2 \%$ share of solar energy by 2025 [6], which is huge compared with the $0 \%$ projections of the past. Based on a projected annual electricity production growth rate of $9 \%, 15 \%$ efficient PV modules and a performance ratio of $75 \%$, this corresponds to roughly $9 \mathrm{GW}_{\mathrm{p}}$.

To achieve this in an economic way, it is important to know how these PV systems perform under Indonesian circumstances (e.g. grid quality and climatological conditions) and where it is most attractive to install these PV systems. A review study of Kaundinya et al. [14] showed that the assessment of the suitability of stand-alone or grid-connected PV systems at a given location, based on techno-economic-financial-environmental feasibility can be improved. In order to capture the uncertainty of these systems, to better forecast the potential of various renewable energy technologies among which solar PV, they conclude that stochastic modeling and simulation studies have to be encouraged in the field of energy studies.

\subsection{Context of PV system research}

To stimulate PV systems in Indonesia, it is necessary that existing barriers to a successful implementation are indicated in order to be tackled. These barriers can be related to a broad number of factors, they can be mainly political, economic, social or technical. One of these barriers is the lack of knowledge about PV systems.

For various actors related to PV systems, like politicians, energy planners, electric utilities, installers and consumers, knowledge about the cost and performance of PV systems is essential to make informed decisions. To support these various stakeholders in their decision-making processes, simulations can play an important role.

Simulations can provide these stakeholders with valuable information about the effects of possible decisions. However, obviously the type of information depends on the situation and actors. For instance, politicians will be more interested in the global long-term performance and costs in order to make decisions about investments in certain energy 
technologies. On the other hand, electric utilities will be more interested in the detailed short-term performance in order to balance the power output of their power plants.

It is clear that next to the aforementioned factors and actors, different levels exist at which energy systems can be evaluated. According to a study by Schenk et al. [15] energy systems can be evaluated at three levels: micro-, meso- and macro-level (see Fig. 1.3).

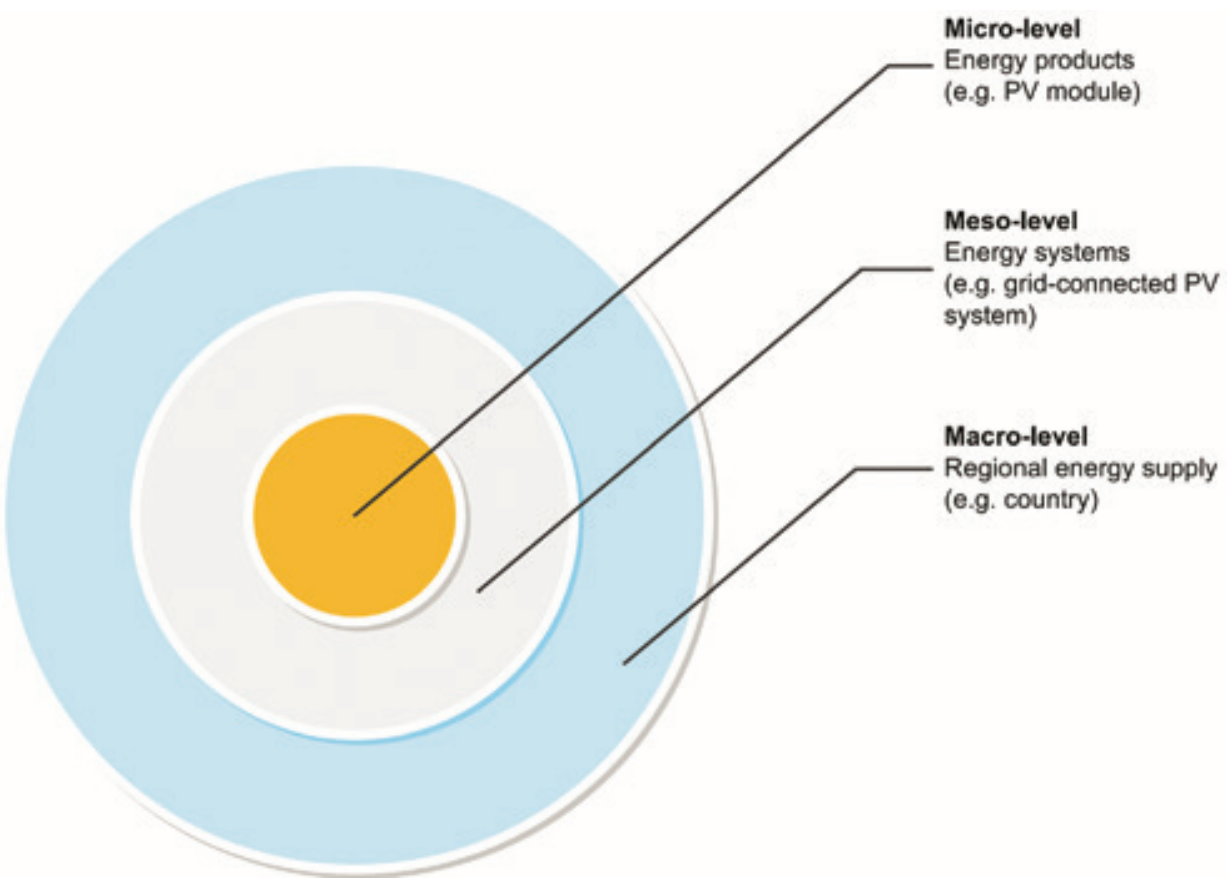

Fig. 1.3. Schematic diagram of the different levels at which PV systems can be evaluated.

In micro-level analysis disaggregated data are favored for specific problems which require technical solutions. It describes the functioning of elements of systems.

In contrast, in macro-level analysis highly aggregated data are preferred for general problems which require policy solutions. It describes the over-all functioning of systems.

Schenk et al. argue that micro-level analysis often introduces an optimistic bias, because contextual requirements are neglected (e.g. grid limitations) and technologies are generally implemented at favorable locations. This optimistic bias is known as the 'engineering paradigm' [16]. Besides, the evaluation at the macro-level is not able to foresee trendbreaking events, because of neglecting heterogeneity of the underlying data. Therefore, they propose to include the analysis at the meso-level, which describes the energy system from an intermediate aggregation level.

Based on the favored levels corresponding to various energy related problems and the level of data aggregation as presented by Schenk et al., each level can be associated with typical problems, solutions, actors and most important parameters related to the energy 
systems. In Table 1-1 an overview is given to show the various interests related to PV systems at the three different levels. The aspects are based on own insights. Rather than presenting a complete overview of all the aspects which are related to PV systems, Table 1-1 illustrates the different aspects related to PV systems at the three distinguished levels. As can be seen, some aspects, such as costs, play a role at every level. Besides, some parameters are related to the same characteristic, but are named differently at distinct levels, such as loss of load probability (meso-level) and reliability (macro-level).

\section{TABLE 1-1: ASPECTS RELATED TO PV SYSTEMS}

\begin{tabular}{|c|c|c|c|}
\hline & Micro & Meso & Macro \\
\hline Favored for & $\begin{array}{l}\text { Specific problems, } \\
\text { 'engineering solutions' }\end{array}$ & $\begin{array}{l}\text { System problems, } \\
\text { 'system solutions' }\end{array}$ & $\begin{array}{l}\text { General problems, } \\
\text { 'policy solutions' }\end{array}$ \\
\hline Focusing on & $\begin{array}{l}\text { PV cells, PV modules, } \\
\text { inverters, batteries }\end{array}$ & $\begin{array}{l}\text { PV systems, grid- } \\
\text { connected energy } \\
\text { systems, transmission } \\
\text { and distribution lines }\end{array}$ & $\begin{array}{l}\text { Energy resources } \\
\text { (utility, availability, } \\
\text { costs, emissions, } \\
\text { safety, sustainability) }\end{array}$ \\
\hline Typical issues & $\begin{array}{l}\text { Production cost, } \\
\text { efficiency, performance, } \\
\text { reliability, } \\
\text { manufacturability, } \\
\text { maintenance, usability }\end{array}$ & $\begin{array}{l}\text { Black-outs, captive } \\
\text { power, electricity } \\
\text { losses, generation cost }\end{array}$ & $\begin{array}{l}\text { Security of supply, } \\
\text { climate change goals, } \\
\text { energy poverty } \\
\text { alleviation, public } \\
\text { health, socio- } \\
\text { economic issues }\end{array}$ \\
\hline Typical solution space & $\begin{array}{l}\mathrm{R} \& \mathrm{D} \text {, product design, } \\
\text { supply chain }\end{array}$ & $\begin{array}{l}\text { Efficiency measures, } \\
\text { storage capacity, ICT, } \\
\text { load forecasting, grid } \\
\text { extension }\end{array}$ & $\begin{array}{l}\text { Laws, subsidies, } \\
\text { policies, technical } \\
\text { standards, education, } \\
\text { media, infrastructure }\end{array}$ \\
\hline Typical actors & $\begin{array}{l}\text { Manufacturers, suppliers, } \\
\text { installers, designers, end- } \\
\text { users }\end{array}$ & $\begin{array}{l}\text { Utilities (PLN), local } \\
\text { government, NGOs }\end{array}$ & $\begin{array}{l}\text { Government } \\
\text { (national, regional \& } \\
\text { local), PLN }\end{array}$ \\
\hline Data aggregation level & Low & Low - intermediate & High \\
\hline Important parameters & $\begin{array}{l}\text { Irradiance, temperature, } \\
\text { weather, system } \\
\text { efficiency, load profile, } \\
\text { costs, willingness \& } \\
\text { ability to pay }\end{array}$ & $\begin{array}{l}\text { Load profile, peak } \\
\text { load, autonomy of } \\
\text { supply, costs, } \\
\text { weather, loss of load } \\
\text { probability }\end{array}$ & $\begin{array}{l}\text { Performance ratio, } \\
\text { resource potential, } \\
\mathrm{kWh} \text { price, } \mathrm{CO}_{2} \\
\text { emissions, reliability, } \\
\text { feed-in tariff, ROI }\end{array}$ \\
\hline
\end{tabular}

In addition, this research can be considered as design research. By evaluating PV systems in the real world rather than the laboratory, it is possible to learn from the installation and performance of a PV system in a specific context. However, this brings some extra challenges with it, since difficulties can arise from the complexity of real world situations and their resistance to experimental control [17]. Furthermore, a PV system is a product which comprises multiple aspects. Although its main function is to supply electricity, the 
success of the PV system depends on other aspects such as end-users, technology, marketing, design \& styling and societal elements. For a successful product all these aspects are believed to be equally important [18].

\subsubsection{Project context}

Aside from the general context, this work is carried out within a project context. This work is part of a project from the Indonesia Facility (INDF). The INDF is part of the Netherlands Enterprise Agency (former NL Agency) and acts under the Dutch Ministry of Economic Affairs. This facility is tasked with promoting good governance in social and economic sectors in order to contribute to sustainable and democratic development in Indonesia. The little experience with grid-connected PV systems in Indonesia and the large potential for this energy source in Indonesia were some of the reasons to initiate the INDF project entitled "Joint Development of a Knowledge Centre on Solar Energy". As the title suggests, the project aimed at the establishment of a knowledge center on solar energy and included the installation of a pilot PV system. The project led by University of Twente ran from February 2011 to January 2013. During this period a new master program on new and renewable energy technologies has been designed and implemented at Institute Teknologi Bandung (ITB), a conference on solar energy has been organized and several trainings and workshops have been given.

The official project partners of this project were the University of Twente (UT), Institute Teknologi Bandung, Solinvest, World Wildlife Fund (WWF) and Kroese Wevers. During the project, other parties got involved as well. In this thesis data derived from this project will be used.

\subsubsection{Focus}

Many studies have focused on the political aspects of the implementation of PV systems and other renewables in Indonesia, which are mainly focused on the macro-level. This is important, especially in Indonesia, in which the subsidies impose large restrictions on the successful implementation of PV systems [7]. However, it is expected that these subsidies will be gradually removed, introducing opportunities for large-scale implementation of grid-connected PV systems. Hence, it is in the interest of several actors, to improve the technical knowledge of these systems in the meantime in order to be better prepared for the foreseeable future. Therefore, the main focus in this thesis will be on the technical factors related to (grid-connected) PV systems, which will be evaluated for each of the three previously mentioned levels. 


\subsection{Research plan}

\subsubsection{Research objective and scope}

The goal in this study is to enhance the technical knowledge about PV systems in Indonesia. The latter will be achieved by literature reviews, potential modeling, monitoring data of a pilot PV system and simulations.

The focus will be on PV systems, other renewable energy technologies will be outside the scope of this study. Besides, although non-technical aspects can play a crucial role in the successful implementation of PV systems, the focus will be mainly on the technical aspects related to PV systems in Indonesia.

This research is new, because little knowledge is available about grid-connected PV systems inside weak grids in Indonesia. Better understanding of the performance of these systems will support the further development. Besides, potential (technical) barriers can be identified in order to improve future PV system installations. Therefore the insights from this study will support the successful implementation of PV systems in Indonesia.

Next to the likely improvements of the quality of lives of the population currently living in areas with bad functioning - or even no - electricity, PV systems help to reduce the dependency on fossil fuels which decreases the $\mathrm{CO}_{2}$ emissions. This benefit is not only limited to the specific area, but impacts the global environment.

\subsubsection{Research question}

The main research question for this thesis is:

What can be learned from experiences with and modeling of PV systems for the stimulation of PV in the future electricity mix in Indonesia?

This main question is divided into several research questions, which will be presented in the various chapters separately.

\subsubsection{Research set-up}

To find answers to the research question, the research is divided into three parts: (I) PV potential mapping, (II) Case study: performance evaluation of PV system in Jayapura, and (III) Simulation of the power output of PV systems.

\section{Part I: PV potential mapping}

At the macro-level, the potential and costs of PV systems in Indonesia will be assessed, providing politicians a way to compare PV with other available (renewable) energy options 
in Indonesia. Based on values found in literature and publicly available data, a model will be developed to determine the potential and costs of grid-connected and off-grid PV systems in Indonesia.

Part II: Case study: Monitoring of a PV system in Jayapura

At the meso-level, the performance of a grid-connected PV system will be evaluated in a weak grid, providing utilities and the (local) government with information about the performance and yield of such system under tropical weather conditions. Measurement data will be used to compare the performance with other PV systems in tropical as well as in non-tropical countries.

\section{Part III: Simulation}

At the micro-level, the power output of the PV modules will be modeled and simulated in order to be able to help system designers to design better PV systems, predict the energy yield and detect faults. Existing models will be applied to simulate the PV power output of the PV system in Jayapura in order to evaluate the suitability of these models in a tropical climate. Besides, since temperature effects on the power output of PV systems play a larger role in a tropical environment, the modeling of the PV module temperature will be studied in more detail. The performance of some widely used PV temperature models will be evaluated for PV modules in Jayapura and in Singapore.

\subsection{Thesis outline}

As shown schematically in Fig. 1.4, the thesis is organized as follows: The next chapter will discuss background information about the electricity situation in Indonesia and about monitoring, simulation and modeling techniques related to PV systems. In Chapter 3, the potential of grid-connected PV systems in Indonesia will be modeled and evaluated. In the subsequent chapter, a similar model will be presented to determine the potential of off-grid PV systems in order to obtain a compete overview of the potential of PV systems in Indonesia. Chapter 5 presents the design and performance of a pilot PV system in Jayapura. In Chapter 6, the power generation of the pilot PV system will be simulated and the results will be evaluated. Subsequently, Chapter 7 will focus on temperature models to simulate the PV module temperature. The different research parts will be followed by a reflection in Chapter 8. Finally, the conclusions and recommendations will be discussed in Chapter 9. 


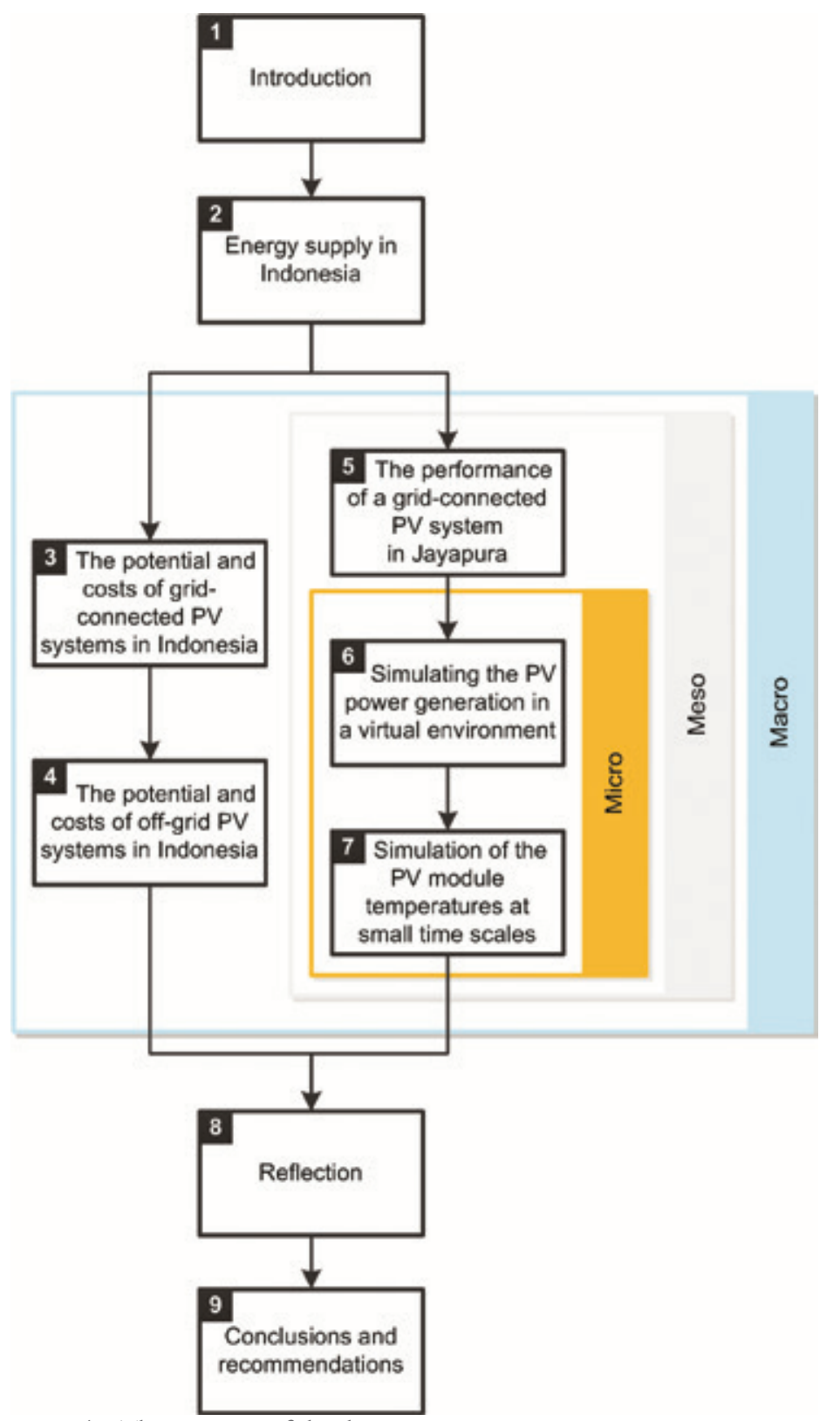

Fig. 1.4. The structure of the thesis 


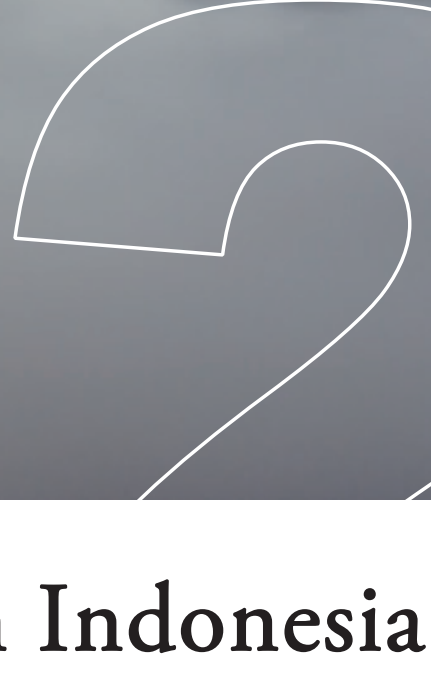

Energy supply in Indonesia 


\section{2}

\section{Energy supply in Indonesia}

In this chapter, a context is given for the application of non-conventional electricity sources, such as solar PV energy, to create a framework for a better understanding of the current electricity situation and challenges. What has been studied before and what could be added to the current literature? In this framework the research questions are posed.

\subsection{Challenges due to population growth, increased wealth and dispersed islands}

The Indonesian government is facing enormous challenges to improve the Indonesian electricity system in order to reach their future goals on grid penetration and greenhouse gas (GHG) emission reduction [19-21]. In the period from 1987 to 2009 electricity production boosted by $620 \%$ [22]; during the same period the electricity production increased with $65 \%$ and $32 \%$ for the Netherlands and the EU-27 countries, respectively [23]. It is expected that the future electricity demand of Indonesia continuous to increase steadily by $9 \%$ annually [20]. The growing energy needs cannot be met by present weak grids, powered by fossil-fuel based plants or diesel generators.

Since Indonesia comprises over 17,000 islands, the distribution of fuels and energy is a challenge due to the geographically dispersed situation, by differences in developments between the main islands Java/Bali and the others, as well as between urbanized and rural regions. These developments are highly linked to the population density, which varies greatly among the different provinces of Indonesia, see Fig. 2.1.

From the same figure can be seen, that Indonesia consists of five large islands, from west to east: Sumatra, Java, Kalimantan, Sulawesi and Papua. 


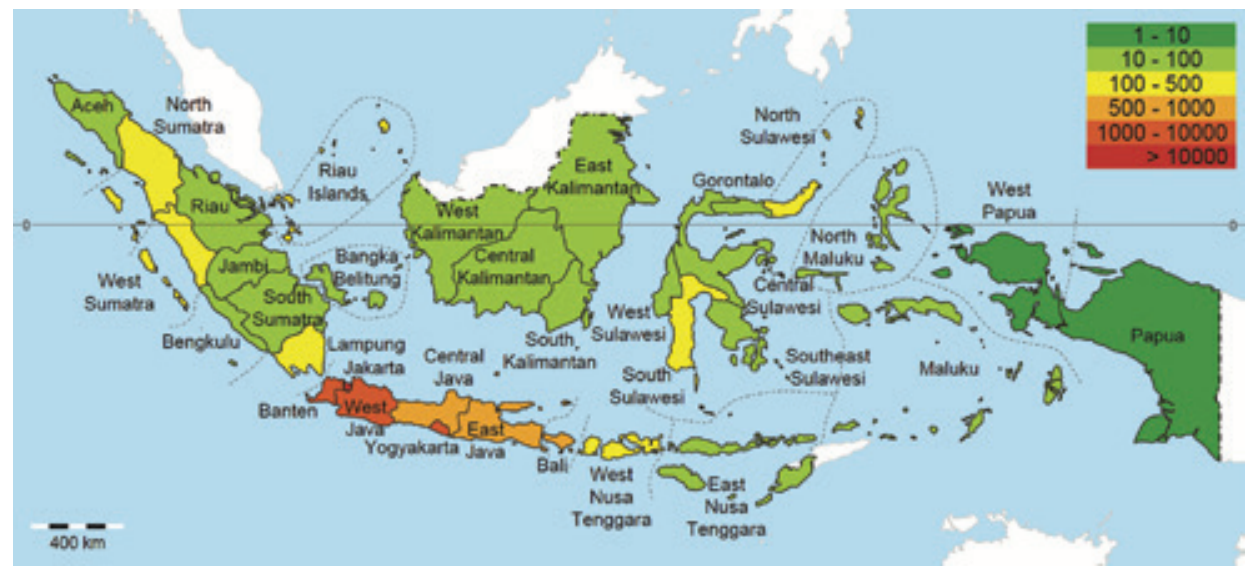

Fig. 2.1. The provinces of Indonesia and their population densities in persons $/ \mathrm{km}^{2}$.

Roughly $50 \%$ of the 238 million inhabitants live in rural areas [24]. This is one of the reasons that the average electrification rate of households in Indonesia, which was $66 \%$ in 2010 [25], is one of the lowest compared with neighboring countries [20, 26]. However, large differences exist among provinces. For instance, high electrification rates of more than $90 \%$ can be found in the provinces Jakarta and Aceh, while low electrification rates of $24 \%$ can be found in Papua and East Nusa Tenggara.

Besides, the inequity between urban (94\%) and rural (32\%) electrification was found to be the largest in Indonesia compared with other big developing countries based on values from 2008 [26, 27]. This is related to the poverty distribution in Indonesia [28]: Regions with high poverty ratios are less attractive for PLN to invest in, because, in general, the profits are low and the financial risks are high. Besides, PLN is not allowed to differentiate in tariff among regions, adding to the unattractiveness of these regions [8]. Moreover, since PLN has mainly expertise in grid-connected energy systems, isolated areas do not get the same attention.

To improve this situation the government aims to increase the electrification rate to $90 \%$ by 2019 [20].

Data on electrification rates of households are limited; however, data from the population census from Statistics Indonesia (BPS) from 2010 are available [24], showing among others information about the primary source of lighting per household, see Fig. 2.2. 


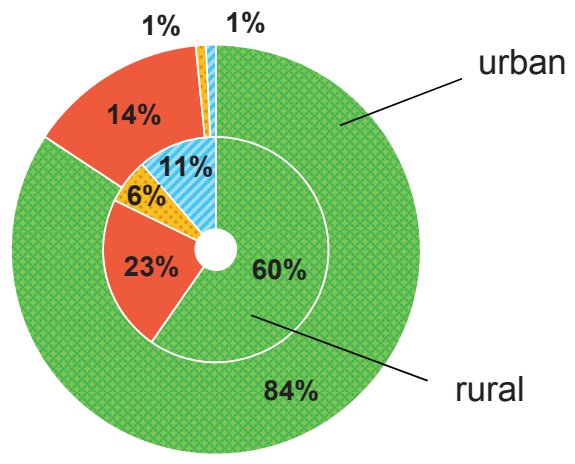

口LN

- PLN (illegal)

ather

$\approx$ No electricity

Fig. 2.2. The primary source of lighting for urban and rural households in Indonesia in 2010. Based on data from BPS [24].

Besides, Fig. 2.2 reveals that a significant share of the Indonesian population - namely, respectively $23 \%$ and $14 \%$ in rural and urban areas - has an illegal connection to the PLN's grid. An analysis of this illegal electricity consumption can be found in Appendix A.

Electricity is transmitted through seven integrated networks, which includes Java-BaliMadura and Sumatra grids, and roughly 600 isolated networks spread over the rest of the islands [29]. This is related to the population density in these areas, which allows investments in grid extensions. About $60 \%$ of the 238 million Indonesians live on the islands Java and Bali [24], in general these islands are better developed than the rest of Indonesia, see Fig. 2.3. Logically, many of Indonesia's small and isolated islands are hardly reachable by a centralized power grid [30].

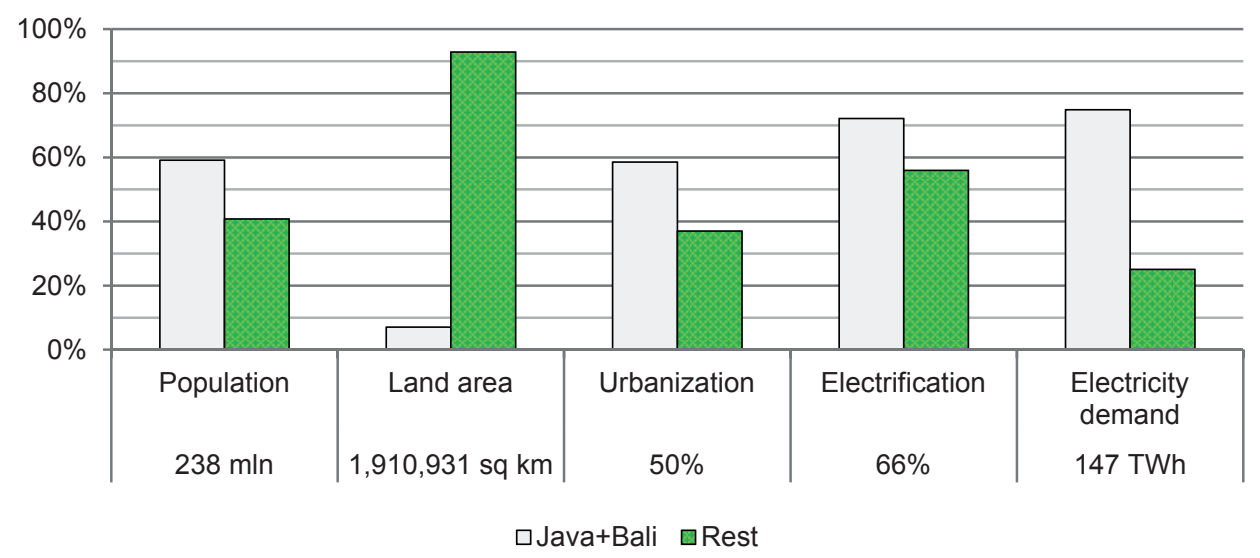

Fig. 2.3. Comparison of the population, land area, urbanization rate, electrification rate and electricity demand for the islands Java-Bali with the rest of Indonesia. Below the bars, total figures are shown for each category. Data are based on the year 2010 and are obtained from BPS [24, 31] and PLN [25]. 
The share of the population lacking access to electricity is not able to profit from the opportunities that energy opens up for income generation. In addition, many Millennium Development Goals in terms of nutrition, health, education and environmental stewardship cannot be met without permanent access to energy. In case energy is available in off-grid situations, expensive and polluting diesel generators are the primary method of power production on most islands of the Indonesian archipelago.

Although Indonesia has abundant renewable energy resources, its electricity production was still highly relying on coal (35\%) and oil (26\%) in 2010 [25], resulting in a high $\mathrm{CO}_{2}$ intense electricity generation [26]. Even though Indonesia is endowed with mineral resources, these sources are finite. At current production rates, the national gas and oil reserves will be depleted in the coming decades [32, 33], therefore, the share of coal is expected to increase in the near future due to its relatively low cost, availability and domestic industry.

The electricity price in Indonesia is heavily subsidized, for instance, the government allocated an amount of 5.1 billion US dollars for electricity subsidies for the year 2012 [34], leading to a reduction of consumer price of electricity, which is significant lower compared with other Southeast Asian countries [26]. Especially on remote islands outside the main islands Java and Bali, expensive diesel is used to generate electricity in a relatively inefficient way [20], which adds to the subsidy burden of the government, taking badly needed resources away from improving infrastructure [35]. For instance, at the province East Nusa Tenggara, the actual electricity production costs were about $15 \phi / \mathrm{kWh}$ whereas the average price sold was less than $8 \mathrm{\phi} / \mathrm{kWh}$ in 2005 [8]. The amount of subsidies for electricity and the dependency on fossil fuels and its inherent distribution problems, will have an adverse effect on the Indonesian economy, therefore, the government should take action toward using more renewable energy resources $[26,28,36]$.

The Indonesian government has taken the important step to remove the monopoly of selling power from PLN, to open up their power sector for private investors. Nevertheless, the increase in capacity is far too slow to tackle Indonesia's low electrification rate and its dependence on fossil fuels.

Indonesia needs to build thousands of MW of new capacity annually to cope with the challenges that come with a country in development, with the current 10,000 MW program - officially known as Fast Track Program - being the first step. PLN, being responsible for the implementation of the Fast Track Program, focuses on large scale project development based on coal, gas and oil, which already dominate the primary energy mix.

Since Indonesia is a tropical country with abundance solar radiation of on average 4.8 $\mathrm{kWh} / \mathrm{m}^{2} /$ year, photovoltaic solar energy can be an excellent solution to electrify remote areas on distributed islands. PV energy is a clean and cost-competitive source of energy, 
which could be produced cheaper than power from diesel generators at some locations. Especially in remote areas, solar power has great advantages, provided that the right conditions are met to make investments from the private sector sufficiently attractive.

\subsubsection{Key figures of the electricity generation in Indonesia}

In Fig. 2.4, the electricity consumption per customer type is shown. Residential customers have the highest share of $41 \%$, followed by industry with $35 \%$. Business and public customers are responsible for the rest, with $18 \%$ and $6 \%$, respectively. With 0.7 MWh per capita, the electricity consumption is relatively low. This is partly caused by the low electrification rate, see Fig. 2.5.

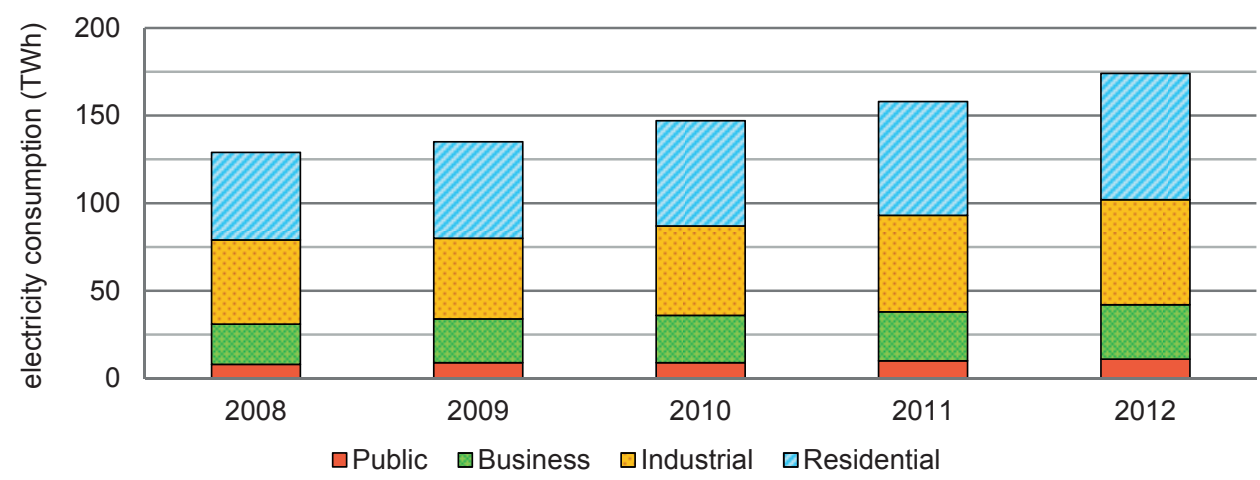

Fig. 2.4. Electricity consumption per customer type in Indonesia for the years 2008 - 2012 [37]

In Fig. 2.5, the electrification rate in Indonesia is shown for the period $2006-2011$. Although large improvements have been made in recent years, the overall electrification rate remains low with a ratio of nearly $73 \%$ in 2011 . Besides, large differences exist between rural and urban areas.

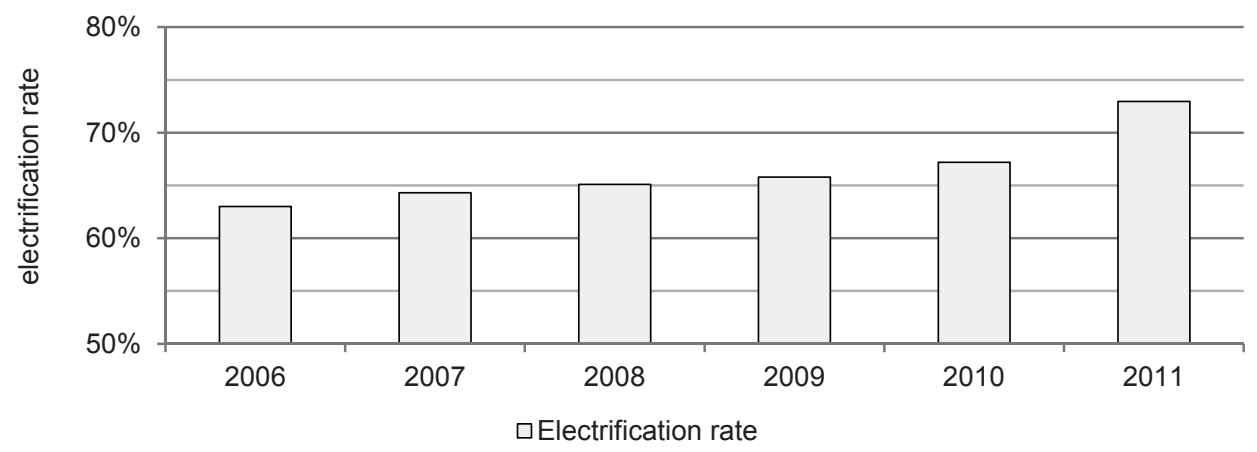

Fig. 2.5. Electrification rate of households in Indonesia for the years 2006 - 2011 [38] 
PLN is the main electricity producer and controls $83 \%$ of the total installed generation capacity of 44,598 MW. The rest is supplied by Independent Power Producers (IPPs). The electricity generation is mainly based on fossil fuels, see Fig. 2.6. To reduce its reliance on expensive diesel generated electricity and to meet rising electricity demand, Indonesia launched the 10,000 MW Fast Track Program Phase I in 2006. This first phase focused on coal-fired power plants, which increases the share of coal in the fuel mix. Phase II of the Fast Track Program started in 2010, in order to build more than 17,000 MW of new capacity, of which $68 \%$ is owned by IPPs. In this second phase, $60 \%$ of the newly added capacity is based on coal, $28 \%$ on geothermal, $10 \%$ on hydro and $2 \%$ on gas [37].

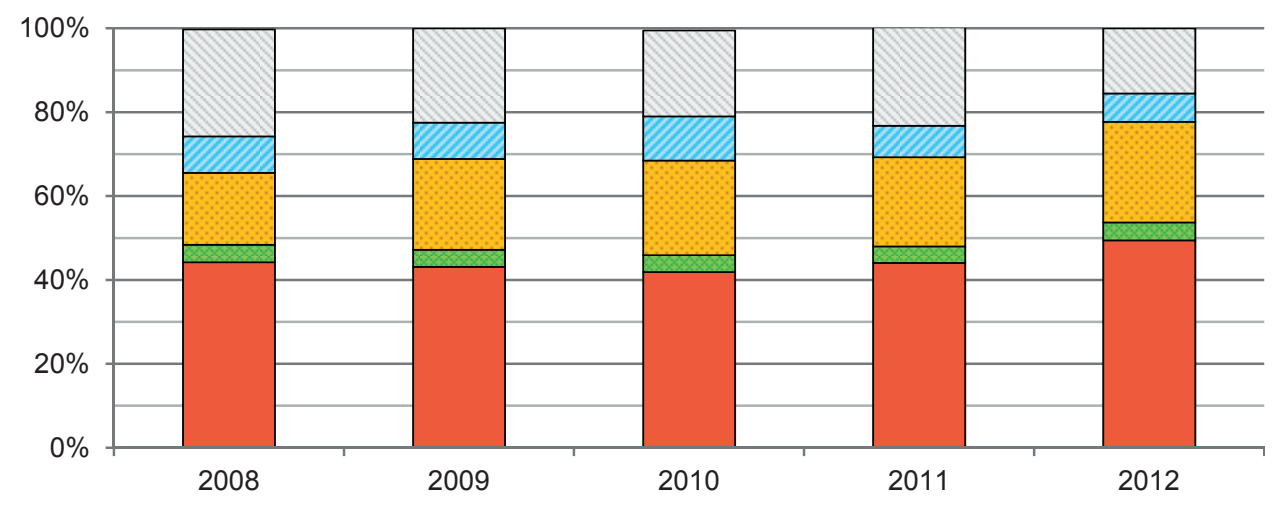

\section{$\square$ Coal $\square$ Geothermal $\square$ Natural gas $\square$ Hydro $\square$ Diesel}

Fig. 2.6. Fuel mix of the electricity production in Indonesia by IPP and PLN for the years $2008-$ 2012 [37].

In contrast to people living in the developed world, which assume electricity to be available at any time, the Indonesian population - especially in rural areas - is used to black-outs. As a result, many households and businesses have their own backup diesel generator; however, running such generator is expensive, polluting and noisy.

\subsubsection{Subsidies}

As already mentioned before, the Indonesian government heavily subsidizes electricity and fuels in order to keep the cost affordable for all income classes in Indonesia. The price of a liter diesel is with USD 0.36 (IDR 4,500) among the lowest in the world in 2012 [39].

In 2011, the Indonesian government spent USD 7.3 billion on electricity subsidies and another USD 13.4 billion on fuel subsidies, amounting to a total of USD 20.7 billion on energy subsidies, corresponding to $29 \%$ of the total expenditure of the government [39].

In recent history, several attempts have been undertaken to increase the fuel prices in order to decrease the subsidies. However, subsidy cuts led often to political instability [21]. 


\subsection{3 $\mathrm{CO}_{2}$ emissions}

Based on $\mathrm{CO}_{2}$ emissions caused by fossil fuel use, Indonesia ranked $15^{\text {th }}$ with 427 Mton in 2011 [23]. Based on the contribution to global temperature change, including among others land-use, Indonesia is ranked $9^{\text {th }}[40]$. In 2009, Indonesia committed itself to reduce its emissions with $26 \%$ by 2020 from business-as-usual levels. Besides, Indonesia aims to have $25 \%$ of renewable energy in 2025 .

The amount of $\mathrm{CO}_{2}$ emissions caused by electricity generation depends on many factors. To estimate the $\mathrm{CO}_{2}$ emissions, the whole life cycle of the particular electricity generation technology has to be taken into account. It depends in a great extent on the applied technology; however, the actual emissions will always depend on local variations as well. For example, the emissions caused by a coal-fired steam turbine depend on, among others: coal quality, distance between the coal mining facility and the power plant, energy used during mining, way of transportation of the coal, and the efficiency of the steam turbine. Therefore, the $\mathrm{CO}_{2}$ emissions of a particular electricity generating technology will have a range of values, as shown in Fig. 2.7.

In general, renewable energy technologies cause lower $\mathrm{CO}_{2}$ emissions compared with technologies based on fossil fuels; however, renewable energy technologies cause emissions as well, albeit more during the production and installation phase than during operation.

For PV, these emissions are found to be in a range of $21-90 \mathrm{~g} \mathrm{CO}_{2}-\mathrm{eq} / \mathrm{kWh}$.

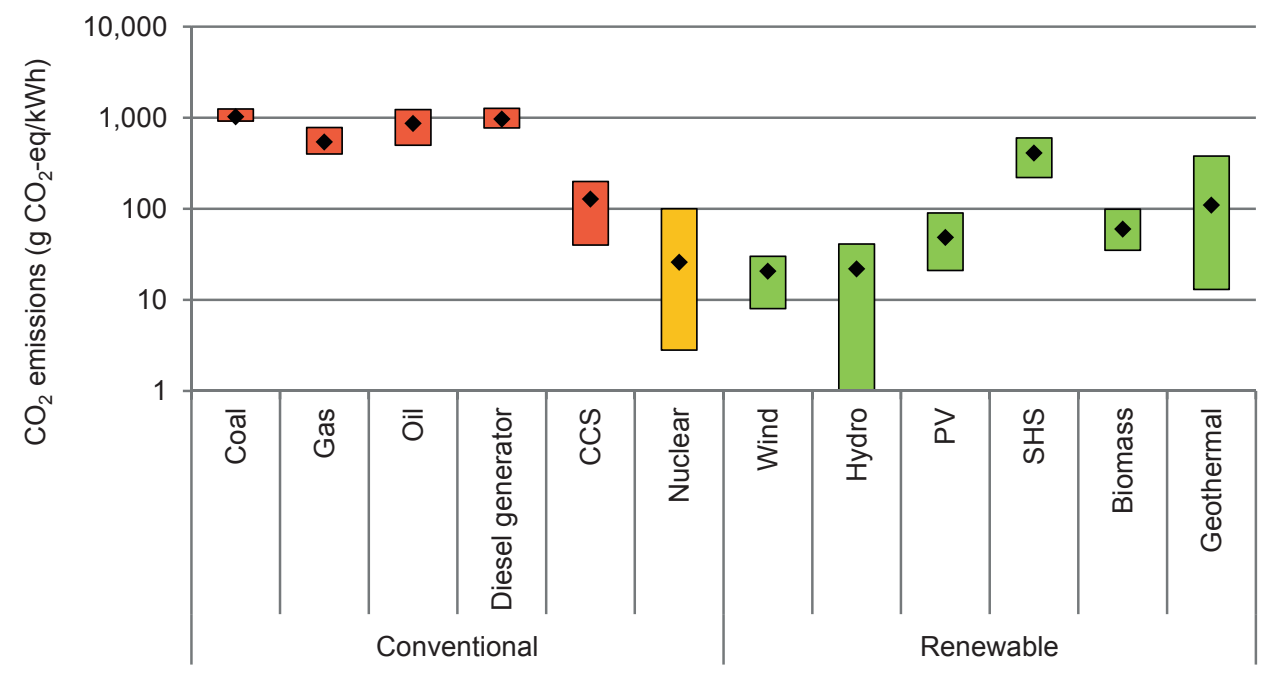

- Average

Fig. 2.7. Typical $\mathrm{CO}_{2}$ emissions from various electricity generating techniques in $\mathrm{g}_{2}$-equivalents per $\mathrm{kWh}$ produced [41-54] 
Because of the low $\mathrm{CO}_{2}$ emissions of renewables, the aimed reduction of $\mathrm{CO}_{2}$ emissions of $26 \%$ by 2020 can be achieved largely by the other target set by the Indonesian government, which aims to reach $25 \%$ of renewables by 2025 .

\subsection{Renewable energy resources in Indonesia}

Indonesia has abundant renewable energy resources; an overview of the renewable energy potentials is given in Table 2-1.

TABLE 2-1: RENEWABLE ENERGY POTENTIALS AND INSTALLED CAPACITIES IN INDONESIA IN 2011

\begin{tabular}{lrll}
\hline Energy source & $\begin{array}{r}\text { Resources* } \\
(\mathrm{GW})\end{array}$ & $\begin{array}{l}\text { Installed capacity } \\
(\mathrm{GW})\end{array}$ & $\begin{array}{l}\text { Ratio }^{+} \\
(\%)\end{array}$ \\
\hline Hydro & 75.7 & 5.7 & 8 \\
\hline Geothermal & 28.5 & 1.2 & 4 \\
\hline Mini/micro hydro & 0.8 & 0.2 & 28 \\
\hline Biomass & 49.8 & 1.6 & 3 \\
\hline Solar & 15,000 & 0.01 & - \\
\hline Wind & 9.3 & 0.002 & 0 \\
\hline
\end{tabular}

Sources: $[55,56]$. The potential of solar energy is based on a back-of-the-envelope calculation, based on the average irradiation of $4.8 \mathrm{kWh} / \mathrm{m}^{2} /$ day in Indonesia.

${ }^{+}$Ratio of installed capacity vs. resource potential

For hydro power, the potential is $75.7 \mathrm{GW}$, of which $34 \mathrm{GW}$ is exploitable. However, about $60 \%$ of these resources are located in Kalimantan and Papua. For mini / micro hydro power, the potential is around $770 \mathrm{MW}$ and around $218 \mathrm{MW}$ has been installed [55]. The largest potential for small scale $(<10 \mathrm{MW})$ hydro plants are in rural areas in Papua and Sumatra [57].

The average wind speeds in Indonesia are around $2-6 \mathrm{~m} / \mathrm{s}$ [58], this wind speed range is suitable for small $(10 \mathrm{~kW})$ to medium scale $(10 \mathrm{~kW}$ to $100 \mathrm{~kW})$ power generations. The main wind energy potential areas are located in East and West Nusa Tenggara, which have average wind speeds of more than $5 \mathrm{~m} / \mathrm{s}$. The approximate wind power potential in Indonesia is about 9.3 GW, and only 1.9 MW of this has been used for generating power, mainly in rural areas [55-57].

The total potential of geothermal energy is around 28.5 GW across more than 250 locations $[55,57]$. Most of this potential can be found on Sumatra (13.8 GW), Java and Bali (9.3 GW), and Sulawesi (2 GW) [56]. Of this total, 14.7 GW are estimated reserves of which $2.3 \mathrm{GW}$ are proven, 11.4 GW are probable, and 1.1 GW are possible resources, the remaining $13.0 \mathrm{GW}$ is still speculative [57]. The total installed capacity is around 1,198 MW, mainly located on Java and Bali $[55,56]$. Although this is just $4 \%$ of the total 
potential, with this installed capacity Indonesia ranks third after the USA (3,098 MW) and the Philippines (1,904 MW), based on values from 2010 [59].

The potential of biomass in Indonesia is around $50 \mathrm{GW}$ [55-57]; the installed capacity was 1.6 GW [55]. Although biomass is a renewable energy source, plantations often replace forests and peat lands in which it results in additional GHG emissions [60]. Besides, when fire is used to clear these areas, significantly more carbon may be released to the atmosphere.

So, although Indonesia is blessed with enough renewable energy potentials, parts of these technical energy potentials have limited economic potential due to the restrictions set by the location of these energy sources (e.g. geothermal and hydro) [56].

In many energy potential studies about Indonesia, the total resource potential of solar PV is often described as $4.8 \mathrm{kWh} / \mathrm{m}^{2} /$ day $[26,55-57]$, which is the average solar irradiation in Indonesia. In 2011, about $14 \mathrm{MW}$ has been installed, mainly off-grid PV systems [55-57]. It is clear that Indonesia receives abundance irradiation; therefore, PV systems can be an excellent solution to electrify remote areas on distributed islands. Although this potential is often recognized in literature, the actual potential of PV systems has not determined in detail so far. A back-of-the-envelope calculation based on the total land area, a performance ratio of $75 \%$, PV module efficiency of $15 \%$ and a land availability factor of $5 \%$, shows a potential for PV systems of roughly $15 \mathrm{TW}_{\mathrm{p}}$. Besides, some rough estimates can be found in literature. A study from the IEA estimated the technical off-grid PV potential to be 900 MW [61], based on $50 \mathrm{~W}_{\mathrm{p}}$ SHSs for 65\% of households without electricity in 1999, assuming 5 people per household. Another study estimates the theoretical off-grid PV potential for Indonesia to be $1,300 \mathrm{MW}_{\mathrm{p}}[62]$, based on $50 \%$ of the population without access to electricity in 2005.

\subsubsection{Solar irradiation}

The average solar irradiation in Indonesia can be divided into two regions, one with approximately $4.5 \mathrm{kWh} / \mathrm{m}^{2} /$ day with a monthly deviation around $10 \%$ for Western regions, and for the Eastern regions, this is about $5.1 \mathrm{kWh} / \mathrm{m}^{2} /$ day with a monthly deviation around $9 \%$ [63].

In Fig. 2.8, the daily average solar irradiation $\left(\mathrm{kWh} / \mathrm{m}^{2} /\right.$ day) for four geographically distributed Indonesian cities is presented for each month. It indicates that in practice, the monthly variability can be between 4 up to $7 \mathrm{kWh} / \mathrm{m}^{2} /$ day.

In Fig. 2.9, the various colours indicate the annual average daily irradiation in $\mathrm{kWh} / \mathrm{m}^{2} /$ day per province ranging from 4.4 to $6.2 \mathrm{kWh} / \mathrm{m}^{2} /$ day. These values are based on satellite derived values from the NASA with a temporal coverage of more than 22 year (July 1983 through June 2005) [64]. 


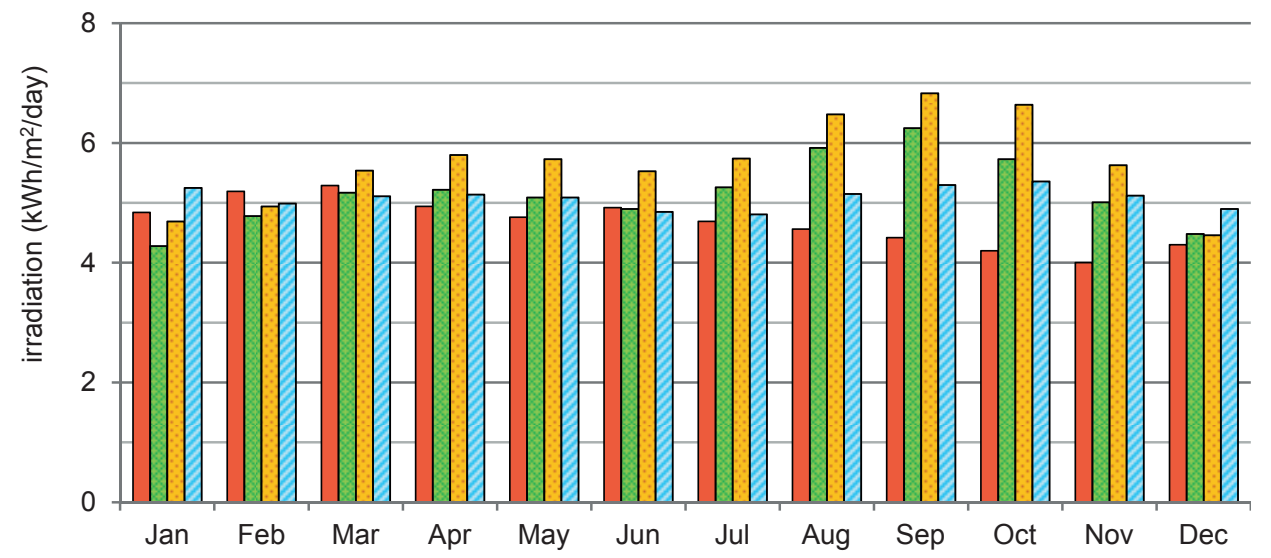

口Medan (Sumatra) $\quad$ JJakarta (Java) $\quad$ Makassar (Sulawesi) $\quad \square$ Jayapura (Papua)

Fig. 2.8. Daily monthly-averaged solar irradiation $\left(\mathrm{kWh} / \mathrm{m}^{2} /\right.$ day) for four Indonesian cities per month. Based on data from the NASA, covering measurements over a period of 22 years between 1983 to 2005 [64].

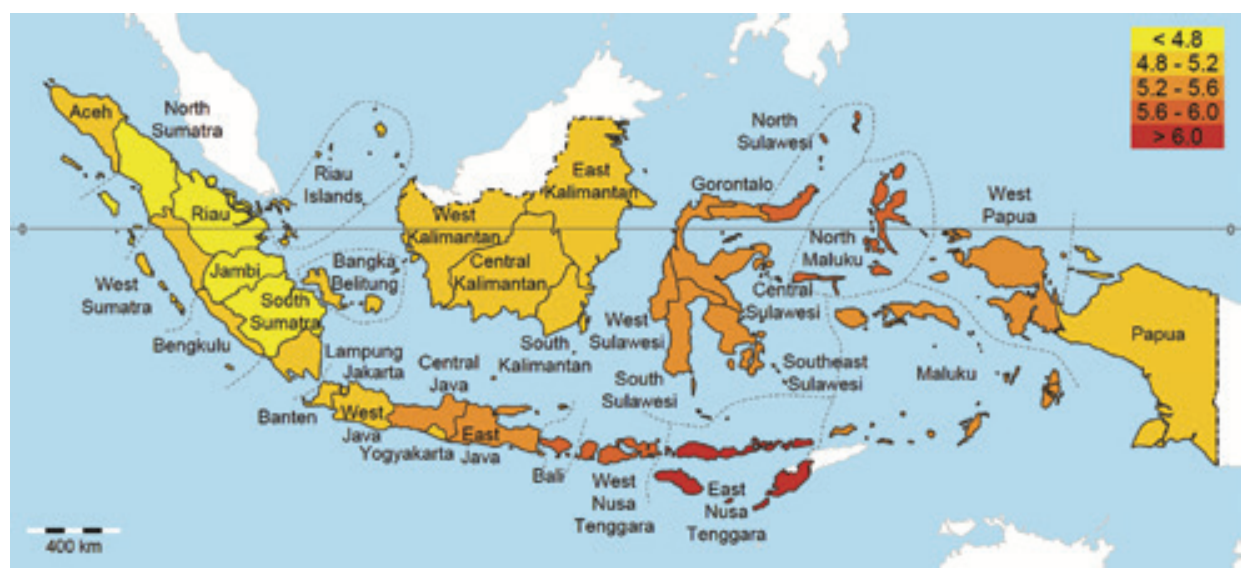

Fig. 2.9. Average daily irradiation in $\mathrm{kWh} / \mathrm{m}^{2}$ for each province in Indonesia. Names of provinces are shown in map. These data were obtained from the NASA Langley Research Center Atmospheric Science Data Center Surface meteorological and Solar Energy (SSE) web portal supported by the NASA LaRC POWER Project.

Due to its location around the equator, the day length in Indonesia varies only slightly during the year. The largest variation is found in East Nusa Tenggara, which is located furthest away from the equator. In this province, the shortest day is 11.5 hours long and the longest day takes 12.7 hours, resulting in a maximum annual difference of 1.2 hours [65]. The relatively small variations in both daily irradiation and day length in Indonesia are beneficial for PV system sizing. 


\subsection{Energy scenario study}

To assist energy planners in their decision making process, energy scenario studies are often used. A broad range of such studies exist, which focus mainly on the potential, cost and feasibility (e.g. technically, economically, environmentally, socially) of one or more energy resources. A wide variety of energy models exist, differences exist in: methodology, mathematical approach, geographical and sectorial coverage, time horizon, data requirements and general vs. specific purpose energy models [66]. In this thesis the focus will be on energy models related to PV systems.

Regarding the technical potential of PV systems, the detailed functioning of PV systems is less important; a rough estimation of the performance ratio or final energy yield is often applied. The economic potential of PV systems is usually less than the technical potential; the former is mainly driven by the overall cost advantage compared with alternatives.

Since the technical resource potential (i.e. available irradiation) for PV systems is presumably not a limiting factor in Indonesia, the potential is highly determined by the actual electricity demand. Since the residential energy consumption accounts for a large share of the total energy demand in a country (30\% on average worldwide) and this consumption is largely undefined compared with other sectors (e.g. industrial and transportation), many studies can be found which aim to model the residential electricity demand [67].

There are two distinct modeling approaches to model the residential electricity consumption: top-down and bottom-up [67]. The former treats the consumption as a total, based on historic aggregated data. The bottom-up approach models the residential electricity consumption based on a representative set of individual houses [67].

Important drivers for residential electricity demand include population, household size, dwelling characteristics, end-user behavior, income, climate and appliances [67, 68]. Residential use differs widely between rural and urban areas and high and low income groups [69], so some studies distinguish different customer groups [68, 69]. Besides, still many households lack access to electricity, which is in most cases not a decision of the household itself, but the result of policy-driven electrification schemes [69].

A number of studies can be found which assess the potential and cost of PV systems. In a study from Breyer et al. [70], a global energy model based on Geographic Information Systems (GIS) has been used to determine the levelized cost of electricity (LCOE) of various energy technologies per location. The LCOE of traditional diesel power has been compared with the LCOE of PV and wind energy systems. The method led to a global map showing the energy technology with the least cost option per location. However, the study focused on electrified areas only, excluding non-electrified settlements from their analysis. Besides, the potential of the nominal installed capacity of PV systems has not been determined. Moreover, because of the global scale, country specific details are ignored. 
A similar spatial-economic analysis has been carried out by Szabo et al. [71], they studied the least cost option for the rural electrification for Africa, based on diesel generators, offgrid PV systems and grid extension. In an updated version, they included microhydropower in their analysis [72]. They found that off-grid PV systems are already costeffective in large areas of Africa. However, it is hard to say whether these findings apply for Indonesia as well, because of differences in climate, grid penetration, population densities and economics for energy supply (e.g. subsidies). Moreover and probably most important, the many islands of the Indonesian archipelago pose a special problem on energy distribution, both for fuels and electricity. For this reason electricity supply in Indonesia has a strong geographic dependency.

Some studies focus on Indonesia specifically. Blum et al. [36] assessed two electricity demand scenarios for the electrification of villages in Indonesia. The LCOEs of off-grid PV systems, micro-hydropower and diesel generators have been evaluated for both scenarios. However, geographic variations are not taken into account, so it is difficult to determine the most suitable region for these technologies. Besides, the study did not focus on the overall potential of PV systems in Indonesia.

A study by Ruijven et al. [73] applied a global model to evaluate the rural electrification in developing countries, including Indonesia. The model focuses mainly on the additional costs to extend the electricity grid to all inhabited rural areas; however, they argue that mini-grids or stand-alone off-grid technologies have quite some potential due to the high cost of grid extension in sparsely populated areas. Solar PV is assumed to be the most suitable technology for stand-alone applications with a generation cost of $0.35-1.2$ $\$ / \mathrm{kWh}$, they found that it has mainly potential in areas with low electricity demand in Indonesia. This study evaluates the required investment on a country level for universal access, but does not calculate the potential of off-grid PV systems and does not take variations inside the country into account.

A study of EPIA estimated the LCOE of PV systems in Indonesia to be $0.177 € / \mathrm{kWh}$ in 2010 [7], however the underlying assumptions and variations inside the country are not presented.

Overall, a detailed, country-specific study of the total potential and costs of both gridconnected and off-grid PV systems in various regions within Indonesia is lacking.

\subsection{Monitoring of PV systems}

To assess the potential and costs of PV systems at a regional level, as described before, the evaluation is typically carried out at the macro-level. In contrast, monitoring of the functioning of PV systems is typically applied at the micro-level.

It is expected that PV systems will play an increasing role in the electricity mix in Indonesia. As a tropical country, Indonesia is blessed with plenty of sunshine. However, most experience with PV systems has been gained in Western Europe and the USA, which 
is also reflected in the standard test conditions (STC) of PV modules, which prescribe a PV cell temperature of $25^{\circ} \mathrm{C}$ and an air mass of 1.5 , corresponding to a solar zenith angle of $48.2^{\circ}$ [74]. The different climatic conditions and infrastructure in tropical areas can have an impact on the performance of PV systems; therefore, it is important to study the performance of PV systems in tropical areas and to compare the results with systems in the rest of the world. Monitoring of the power output, the PV module temperature and weather variables are essential to evaluate the performance and to explain the functioning of PV systems under these circumstances.

The performance ratio (PR) is a widely used indicator of the overall performance of PV systems. In the past decades, large advancements have been made. Grid-connected PV systems installed in Western Europe in the early 90s, achieved average PRs of $65 \%$ and were typically ranging from 50-80\% [75], indicating large uncertainties and room for improvement. Nowadays, the PRs have been increased to an average of roughly $80 \%$ and the best PV systems approach a PR of 90\% [76].

In Indonesia most experience with PV systems is obtained with stand-alone PV systems; however, although thousands of SHSs have been installed in Indonesia, remarkably little information is available on the technical performance of these systems. Monitoring data from stand-alone PV systems installed in Indonesia in the late $80 \mathrm{~s}$, showed an average PR of $49 \%$ within a range of $36 \%-62 \%$ [77]. This is lower than grid-connected systems, though one should place this in perspective: Stand-alone PV systems are more vulnerable to failures, due to the inclusion of a battery and due to a larger dependence on the user behavior. Besides, compared with the reported PRs of grid-connected PV systems in Western Europe in the early 90s, the PR is not that bad. It is expected that the PRs of these stand-alone PV systems in Indonesia have slightly improved as well in the last decades; however, comprehensive studies on this topic are limited.

Performance data of grid-connected PV systems in Indonesia are practically absent, but the expectation is that the PR of these systems will be slightly less than those in Europe, because of the higher operation temperatures and weaker grids. A study of a grid-connected BIPV system in another tropical country - Colombia - shows a PR in the range of $44 \%$ $61 \%$ during two years [78], but the situation in Indonesia could be significantly different.

So, to study the performance of grid-connected PV in Indonesia, monitoring data are essential and relevant to get better insights in the performance of grid-connected PV inside weak grids under Southeast Asian climate conditions.

To monitor PV systems, national and international guidelines exist. Standards for analytical monitoring of PV systems from the JRC [79] and Dutch guidelines for gridconnected PV systems [80] are available. These guidelines prescribe which quantities in which manner have to be measured and analyzed. Besides, they describe ways to present the obtained monitoring data. 


\subsection{Modeling and simulation of PV systems}

Apart from studying the performance of PV systems, PV system monitoring data are important for the mathematical modeling of these systems: Existing models can be validated and new models can be derived by analyzing monitoring data.

A wide variety of models exist regarding the technical performance of PV systems, ranging from models to estimate the irradiance received by PV modules, such as the Liu and Jordan isotropic sky model [81] or the anisotropic sky model of Perez et al. [82], and models for the estimation of the PV module temperature [83, 84], to models of the electrical performance of PV modules [83, 85] or complete PV systems [86, 87].

The developed models can be used to simulate PV systems. Simulations consist of mathematical models in which the input variables can be changed to study the functioning of the PV system under varying circumstances. Simulations allow the evaluation of situations which are too costly, too dangerous or even impossible to study in practice.

As with the underlying models, simulations can be used for a broad range of topics and for different levels of detail [88]. For instance, it can be used to generate synthetic data in situations where the available information is limited, in order to evaluate these situations. Besides, simulations can assist PV system designers to design better PV systems, for example, by calculating the final yield of various designs. Moreover, simulations can be used to predict the power output of these systems during the operational phase, this can be applied to detect system failures and to forecast PV power inside an electricity grid in order to balance the supply and demand of electricity more efficiently. And again, monitoring data can be applied to validate the simulation results and can help to improve the simulation procedures at the same time.

Many software tools for PV systems exist already. A study by the IEA [89] gives an overview of these software tools for PV systems and divided these into four groups: dimensioning, simulation, research and mini-grid design tools.

Dimensioning tools are mainly used by system installers to optimally size the different components based on the required electricity. Differences can exist in the objectives of optimization among the tools, such as life cycle costs or energy performance [89]. Examples of such tools are: RETScreen, HOMER, PVsyst and PV*SOL [89].

Simulation tools are used to simulate the behavior of the system over a given period based on input data, such as load and weather data. The user can define each component and subsequently these tools can provide a detailed analysis of the behavior of the system, such as voltage and current output and energy yield. Simulations can be applied to verify system sizing, investigate the performance under specific weather conditions, study the sensitivity of different components to important design parameters and to analyze system failures [89]. Examples of this kind of software tools are: HOMER, Hybrid2, PVsyst, PV*SOL and Solar Pro [89, 90]. 
Research tools are highly flexible, but the inherent complexity make them less useful for commercial applications, besides most are developed for internal use [89]. In this kind of tools, it is possible to modify the underlying algorithms which determine the behavior of the PV system or its components [89]. Examples of this kind of software tools are: PowerSim, MATLAB/Simulink, INSEL, PVToolbox for MATLAB, Dymola and PowerFactory $[89,90]$.

Mini-grid design tools can be used to determine the cost-effectiveness of grid-connection vs. stand-alone PV systems or to select the right cross section of the distribution cables which minimizes power losses [89]. Examples of this kind of software tools are: Vipor and Jpélec [89].

For the analysis of a grid-connected PV system, simulation tools are the most appropriate; however, existing tools have some limitations. The time resolution varies among the tools, from time steps ranging from an hour, day, week, month or year; however, most tools use a time step of an hour and cannot be used for smaller time steps. From the investigated tools, only Hybrid2 [89] and HOMER [88] show this ability. Besides, shadowing analysis is not included in some of the software packages such as HOMER and Hybrid2, or are limited in use [89]. To analyze complex shading, Computer Aided Design (CAD) software can be used. Some software packages have the ability to include 3D objects of the building and other surrounding objects to analyze shadows, such as PV*SOL and PVsyst [89]. In general, free tools are relatively simplistic and do not allow for detailed modifications. Some commercial tools (e.g. PV*SOL, PVsyst) show more options to modify settings; however, these do not allow complete flexibility. The commercial software program TRNSYS is highly flexible, it is based on Fortran code blocks; at the development level it requires familiarity with this programming language [89], besides the software is expensive. Many research tools are for internal use only, lack the ability to include and design $3 \mathrm{D}$ objects and require a lot of time to become acquainted with.

So, a suitable, inexpensive simulation tool to analyze the performance of PV systems including shadow analysis at small timescales (i.e. less than an hour), which has the capability of modifying underlying algorithms, is lacking.

Besides, as with the experience with PV systems, most models included in these simulation tools are developed and validated in regions at higher latitudes, therefore it would be interesting to know how these models perform in Indonesia as well. Up till now, few studies exist which study existing models in tropical areas such as Indonesia. 


\subsection{Research questions and setup of thesis}

Indonesia faces huge challenges to improve its electricity system. PV systems can play a key role to tackle the low electrification rates and decrease the fossil fuel dependency simultaneously. PV systems can be applied as grid-connected or as stand-alone (off-grid) systems. Indonesia has already gained extensive experience with these off-grid PV systems; however, grid-connected PV systems are relatively new and the experience with and knowledge of these systems are limited in Indonesia.

In section 1.4.2 the main research question of this thesis was formulated as: What can be learned from experiences with and modeling of PV systems for the stimulation of $P V$ in the future electricity mix in Indonesia? Based on the literature review in this chapter, some sub questions can be defined.

In order to make comparisons regarding PV systems with other energy resources less cloudy, it would be necessary to shed some light on the potential and cost of PV systems in Indonesia, therefore, the following sub question has been formulated:

- What is the potential and cost-effectiveness of PV systems in Indonesia?

To model these potentials and costs, a distinction has been made between off-grid and grid-connected PV systems, since they differ from their requirements, applications and designs. The next chapter will focus on grid-connected PV systems, the off-grid PV potential will be evaluated in Chapter 4, in order to obtain a complete picture of the potential and costs of PV systems in Indonesia.

To investigate the performance of a grid-connected PV system inside a weak grid under tropical climate conditions in Indonesia, a pilot PV system will be monitored and evaluated. The sub question related to this is:

- What is the performance of a grid-connected PV system in Indonesia?

In Chapter 5 the performance of a grid-connected PV system will be evaluated.

Further has been found, that most models to simulate PV systems are based on locations at higher latitudes. Therefore, the following sub question has been defined:

- How well do PV power output simulations, based on existing models evaluated for Western climates, perform in Indonesia, by applying locally and publicly available weather data?

Chapter 6 will evaluate the simulation of the pilot PV system, and Chapter 7 will evaluate temperature models for PV modules in more detail. 


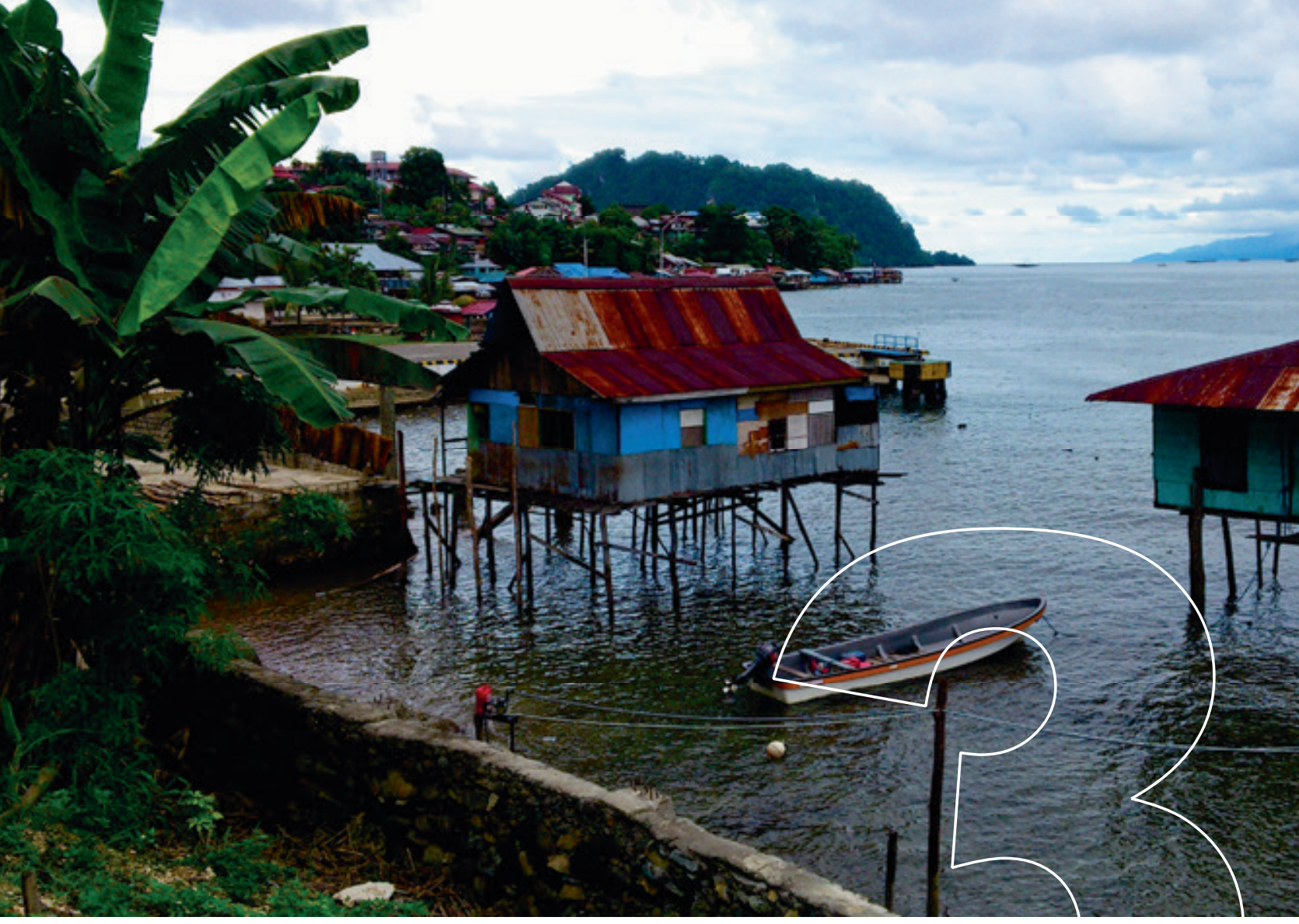

\section{The potential and costs of} grid-connected PV systems

\section{in Indonesia}

This Chapter is based on a study which has been published as manuscript in the Journal of Renewable and Sustainable Energy Reviews. A.J. Veldhuis, A.H.M.E. Reinders, Reviewing the potential and cost-effectiveness of grid-connected solar PV in Indonesia on a provincial level, volume 27, pp. 315-324, November 2013. 


\section{3}

\section{The potential and costs of grid-connected PV systems in Indonesia}

In this chapter a methodology is developed to model the potential and costs of gridconnected PV systems in Indonesia. The cost-effectiveness of these systems is evaluated against the actual generation cost of electricity by PLN.

\subsection{Introduction}

From the literature review in previous Chapter 2 it follows that the potential of gridconnected PV systems in Indonesia has not been determined in detail so far, making comparisons among resources difficult. In theory, the energy potential is equal to the country's area times the average irradiation and the average PV system efficiency, however this is not very realistic; the actual potential depends on various factors, such as: irradiation, land availability, electricity demand and the cost of electricity [91].

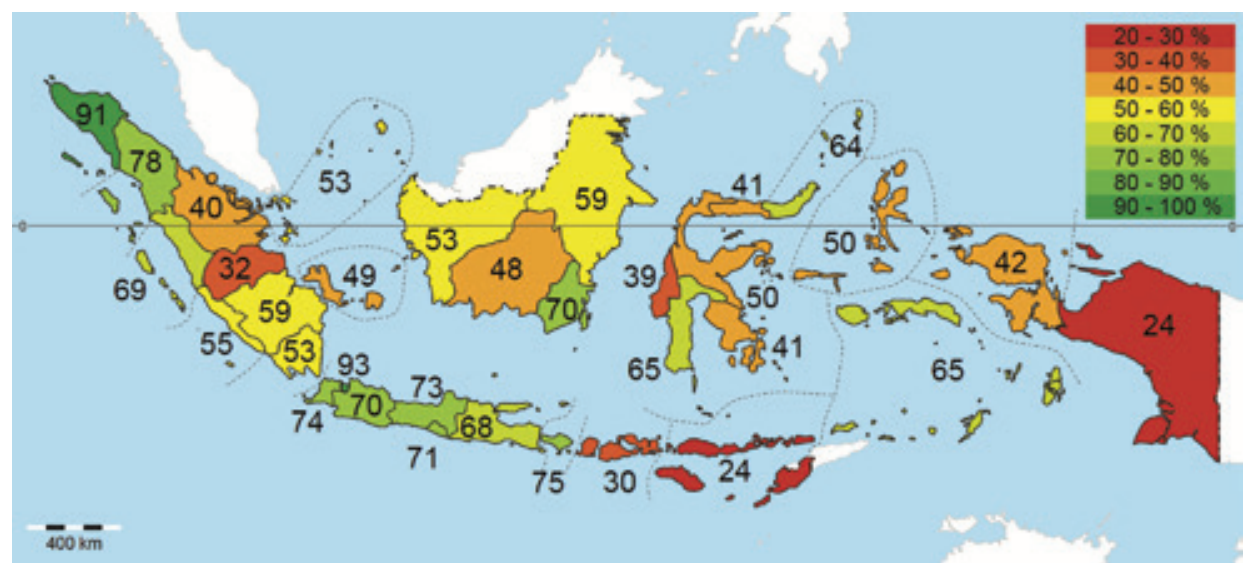

Fig. 3.1. Electrification rate of households per province in Indonesia in 2010. Based on data from PLN [25].

As can be seen in Fig. 3.1, large spatial differences exist in the electrification rates among the provinces in Indonesia. For instance, high electrification rates of more than $90 \%$ can be found in the provinces Jakarta and Aceh, while low electrification rates of $24 \%$ can be found in Papua and East Nusa Tenggara. Other factors related to grid-connected PV 
systems differ greatly as well among the provinces; therefore this study aims to assess the potential and cost-effectiveness of these systems in Indonesia on a provincial level. To assess the actual potential of grid-connected PV, a mathematical model is developed based on literature studies and available data for each of the 33 provinces in Indonesia. Among others, the model takes into account: population, electrification rate, irradiation, electricity demand, electricity generation costs and the urbanization rate.

Since data about geographic locations with grid connection are not publicly available, a new method has been developed to determine the area suitable for grid-connected PV systems which is based on: land area, population, electrification rate and urbanization rate.

Based on the availability of data, this study focuses on statistics from the year 2010 .

\subsubsection{Research questions}

The main research question in this chapter is: What is the potential and cost-effectiveness of grid-connected PV systems in Indonesia? This question can be divided into the following sub questions:

- What is the potential of PV systems in Indonesia?

- Which factors determine the potential?

$\circ$ What is their $\mathrm{CO}_{2}$ reduction potential?

- How cost-competitive are PV systems compared with existing electricity generation costs in Indonesia?

- What is the current electricity generation cost?

What are the costs of PV systems in Indonesia?

\subsubsection{Outline}

In the next section 3.2 the methodology, the applied input data and the constraints of this model will be described. Section 3.3 presents the results for energy potential and costeffectiveness along with a sensitivity analysis, followed by a discussion in section 3.4 and finally in section 3.5 the conclusions are presented.

\subsection{Modeling the potential of grid-connected PV}

To calculate the actual potential of grid-connected PV the following general assumptions have been made: (1) population density is a major factor, (2) other renewable energy technologies are not taken into account, (3) the calculations will be based on gridconnected systems without storage, (4) the model is based on a provincial level, so local variations inside the province itself are outside the scope of this study. Furthermore, the approach to determine the suitable area, energy demand and costs are described in the next sections, 3.2.1, 3.2.2 and 3.2.3, respectively. The actual generation cost of electricity is described in section 0 . 


\subsubsection{Suitable area}

Since this study focuses on grid-connected PV, the suitable area for PV is limited to areas where an electricity grid is already available. This area with grid connection is hard to determine due to a lack of data about grid distribution at the low voltage level. In general, only the major high voltage transmission lines are known, therefore a new method is developed to determine this area. A relation among the population, population density, urbanization rate and the electrification rate of the particular province is proposed. As can be seen in Fig. 3.2, the population is not uniformly distributed and large differences exist between rural and urban areas.

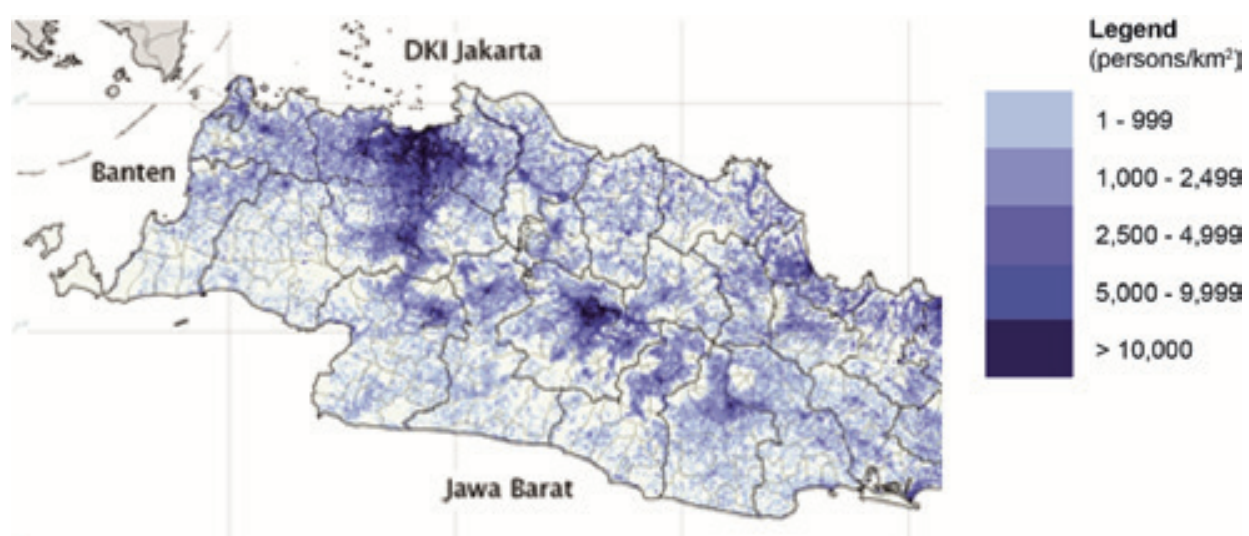

Fig. 3.2. Population density map of the western part of Java. The map is compiled from results from the 2000 Population Census by BPS Indonesia and Japan International Cooperation Agency [92].

Since an electricity grid is expensive and only cost-effective in densely populated areas, it is expected that densely populated areas have had priority over sparsely populated areas regarding grid connection [26, 73]. In this study each province is divided into four different areas based on the population density, in order from high to low, these are: (1) urban cores, (2) suburbs, (3) villages and (4) rural areas, see Fig. 3.3. It is assumed that the electricity grid is extended in the same sequence, from urban cores to rural areas. Furthermore, it is assumed that rural areas do not have an electricity grid and are thus not suitable for grid-connected PV. 


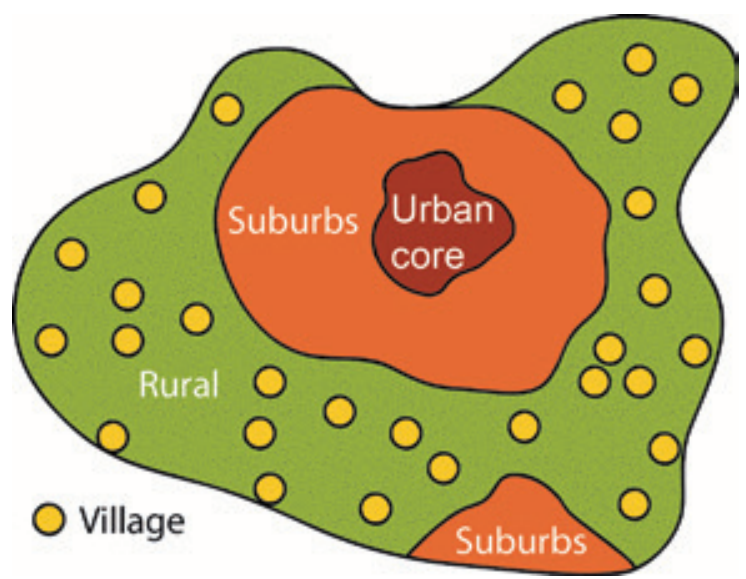

Fig. 3.3. Schematic representation of the classification of the four areas inside a province: 1) urban core (red), 2) suburbs (orange), 3) villages (yellow) and 4) rural areas (green).

The population $N$ in province $p$ which is connected to the grid, $N_{p, g c}$, is determined as follows:

$$
N_{p, g c}=N_{p} \times E R_{p}
$$

where $N_{p}$ is the population of the province, based on data from Statistics Indonesia (BPS) [24], and $E R_{p}$ is the electrification rate of the households in the province, based on data from PLN [25].

The population in the urban core with grid connection in province $p, N_{p, q c, l}$, is determined as follows:

$$
N_{p, g c, 1}=\left\{\begin{array}{c}
N_{p, 1}, N_{p, 1} \leq N_{p, g c} \\
N_{p, g c}, N_{p, 1}>N_{p, g c}
\end{array}\right.
$$

where $N_{p, 1}$ is the population living in the urban core ${ }^{2}$ according to BPS [24]. The total population in the suburbs and urban cores of a province, $N_{p, 1,2}$, is determined as follows:

$$
N_{p, 1,2}=N_{p} \times U R_{p}
$$

where $U R_{p}$ is the urbanization rate of the province according to BPS [24].

BPS classifies a village as urban if it satisfies the following three conditions: (a) a population density of at least 5,000 persons per square kilometer, (b) 25 per cent or less of

\footnotetext{
2 The number in the subscript indicates the classification of the area, in this case the number 1 indicates the area classified as urban core.
} 
the households working in the agriculture sector, and (c) eight or more urban-related facilities like post office, bank, cinema, hospital, and school [93].

Next, the suburban population connected to the grid, $N_{p, g c, 2}$, is determined according to:

$$
N_{p, g c, 2}=\left\{\begin{array}{l}
N_{p, 1,2}-N_{p, g c, 1}, N_{p, 1,2} \leq N_{p, g c} \\
N_{p, g c}-N_{p, g c, 1}, N_{p, 1,2}>N_{p, g c}
\end{array}\right.
$$

Similarly, the population in villages with grid-connection, $N_{p, g c, 3}$, is determined:

$$
N_{p, g c, 3}=\left\{\begin{array}{c}
N_{p, g c}-N_{p, 1,2}, N_{p, 1,2}<N_{p, g c} \\
0, N_{p, 1,2} \geq N_{p, g c}
\end{array}\right.
$$

Now the populations for the various areas are determined, the corresponding land areas can be calculated. The sizes of the various areas are obtained by dividing the population of the distinguished area by its average population density. For simplicity, the average population density in Indonesia for these distinguished areas is assumed to be equal for each province, see Table 3-1.

The land area of the urban cores with grid-connection is calculated as follows:

$$
A_{p, g c, 1}=\left\{\begin{array}{l}
\frac{N_{p, g c, 1}}{\overline{N D}_{1}}, \frac{N_{p, g c, 1}}{\overline{N D}_{1}} \leq A_{p, 0.8} \\
A_{p, 0.8}, \frac{N_{p, g c, 1}}{\overline{N D}_{1}}>A_{p, 0.8}
\end{array}\right.
$$

where $A_{p, g c, l}$ is the provincial urban core area in $\mathrm{km}^{2}$ wherein the population is connected to the electricity grid, $\overline{N D}_{1}$ is the average population density of urban cores in Indonesia in persons $/ \mathrm{km}^{2}$ and $A_{p, 0.8}$ is $80 \%$ of the total land area of the province in $\mathrm{km}^{2}$ [31]. At least $20 \%$ of the land area of each province is assumed to be uninhabited, which affects the island Java only, because of its high population density. For the Special Capital Region of Jakarta an exception has been made and $100 \%$ of the total land area can be inhabited, since it is a relatively small area $\left(664 \mathrm{~km}^{2}\right)$ and very densely populated.

The suburban grid-connected area in province $p, A_{p, g c, 2}$, is determined in a similar way:

$$
A_{p, g c, 2}=\left\{\begin{array}{l}
\frac{N_{p, g c, 2}}{\overline{N D}_{2}}, \frac{N_{p, g c, 2}}{\overline{N D}_{2}}+A_{p, g c, 1} \leq A_{p, 0.8} \\
A_{p, 0.8}-A_{p, g c, 1}, \frac{N_{p, g c, 2}}{\overline{N D}_{2}}>A_{p, 0.8}
\end{array}\right.
$$

where $\overline{N D}_{2}$ is the average population density in suburban areas in Indonesia. 
The area of the grid-connected villages can be found using the following formula:

$$
A_{p, g c, 3}=\left\{\begin{array}{l}
\frac{N_{p, g c, 3}}{\overline{N D}_{3}}, \frac{N_{p, g c, 3}}{\overline{N D}_{3}}+A_{p, g c, 1}+A_{p, g c, 2} \leq A_{p, 0.8} \\
A_{p, 0.8}-\left(A_{p, g c, 1}+A_{p, g c, 2}\right), \frac{N_{p, g c, 3}}{\overline{N D}_{3}}>A_{p, 0.8}
\end{array}\right.
$$

where $A_{p, g c, 3}$ is the area in $\mathrm{km}^{2}$ of the villages in the province wherein the population is connected to the electricity grid and $\overline{N D}_{3}$ is the average population density of villages in Indonesia.

Although it is theoretically possible that the areas $A_{p, g c, 2}$ and $A_{p, g c, 3}$ become zero based on the equations (3.6)-(3.8), this only happens for the Jakarta province wherein the populations of the corresponding suburban and village areas are equal to zero.

The technical production potential of grid-connected PV systems for each province of Indonesia is calculated according to the following formula:

$$
E_{p, P V, g c, p o t, y}=d_{y} \cdot \eta_{P V} \cdot \bar{H}_{p, d} \cdot \sum_{i=1}^{3} L A_{i} \cdot A_{p, g c, i} \cdot P R_{i}
$$

where $E_{p, P V, g c, p p t, y}$ is the potential annual electricity production of grid-connected PV of the province in GWh/year, $d_{y}$ is the number of days per year, $\eta_{P V}$ is the efficiency of the PV modules, $P R$ is the performance ratio, $\bar{H}_{p, d}$ is the average irradiation in $\mathrm{kWh} / \mathrm{m}^{2} / \mathrm{d}$ of the province, $L A$ is the land availability factor for grid-connected PV and the subscript $i$ indicates the area type ( $1=$ urban core, 2 = suburban, 3 = village). In Table $3-1$ the values for the various factors are presented.

The population density of 8,000 persons per square kilometer for urban cores is based on the average population density of the largest cities in Indonesia [94]. The population density of 5,000 persons per square kilometer for suburbs equals the minimum population density which is applied by BPS [93] to classify a certain area as urban. The population density of 1,000 persons per square kilometer is assumed to be the average for rural villages with grid-connection in Indonesia.

In this study, the selected PV technology is multi-crystalline silicon. The module efficiency $\eta_{P V}$ of multi-crystalline silicon is assumed to be $15 \%$. The performance ratio $P R$ of grid-connected PV in Indonesia is estimated to be $75 \%$ for urban cores and $80 \%$ for suburban areas. These values are slightly lower than European systems, because high ambient temperatures and high irradiance in this tropical climate will more prominently induce a temperature effect on the performance of crystalline silicon PV modules. Because of higher temperatures and shading due to surroundings, the PR for urban cores is assumed 
to be $5 \%$ lower compared with suburban areas. The PR of grid-connected PV is assumed to be $70 \%$ in rural areas, due to a lower and more unstable electricity demand and higher transmission losses due to longer distances.

TABle 3-1: Assumptions FOR SOME PARAMETERS FOR THE CALCULATION OF THE POTENTIAL OF GRID-CONNECTED PV.

\begin{tabular}{lrl}
\hline Variable & Value & Unit \\
\hline$\overline{\mathrm{N}}_{1}$ & 8,000 & persons $/ \mathrm{km}^{2}$ \\
\hline $\bar{N}_{2}$ & 5,000 & persons $/ \mathrm{km}^{2}$ \\
\hline $\bar{N}_{3}$ & 1,000 & persons $/ \mathrm{km}^{2}$ \\
\hline $\mathrm{L} A_{1}$ & 5 & $\%$ \\
\hline $\mathrm{LA}_{2}$ & 10 & $\%$ \\
\hline $\mathrm{LA}_{3}$ & 15 & $\%$ \\
\hline $\mathrm{PR}_{1}$ & 75 & $\%$ \\
\hline $\mathrm{PR}_{2}$ & 80 & $\%$ \\
\hline $\mathrm{PR}_{3}$ & 70 & $\%$ \\
\hline
\end{tabular}

\subsubsection{Electricity demand}

The amount of grid-connected PV in a particular province is related to the electricity demand of its population. The total amount of electricity generated by grid-connected PV (GWh) should not exceed the electricity demand in the province. The electricity demand is based on the data per province over 2010 from PLN [25]. It contains the total electricity consumption per customer type over the year 2010. Since no storage system is assumed, assumptions have been made regarding the electricity demand per customer type during Indonesian daylight time, see Table 3-2. Further, it is assumed that this demand profile is uniform in Indonesia.

TABle 3-2: Assumptions of THE Electricity Demand During Daylight Time FOR EACH CUSTOMER TYPE OF PLN [25]

\begin{tabular}{ll}
\hline Customer type & Demand daylight time \\
\hline Residential & $40 \%$ \\
\hline Industrial & $80 \%$ \\
\hline Business & $60 \%$ \\
\hline Social & $70 \%$ \\
\hline Governmental building & $90 \%$ \\
\hline Street lighting & $0 \%$ \\
\hline
\end{tabular}


An extra limitation of the total electricity generated by PV is related to the base load and the flexibility of the existing base load power plants. There is a minimum level to which conventional generators can be 'turned down' with minimal economic penalty [95]. The base load is assumed to supply $80 \%$ of the electricity demand during night time and the minimal load constraint is assumed to be $90 \%$ of this amount.

$$
E_{p, \text { demand,min }, y}=E_{p, \text { demand,night }, y} \times 0.8 \times 0.9
$$

where $E_{p, d e m a n d, m i n, y}$ is the minimal electricity produced by existing electric power systems and $E_{p, d e m a n d, n i g h t, y}$ is the electricity demand during night time in the province, both in GWh/year.

The maximum amount of electricity generated by PV $E_{p, P V, \text { demand,y }}$, based on the electricity demand, is therefore:

$$
E_{p, P V, \text { demand }, y}=E_{p, \text { demand,daytime,y }}-E_{p, \text { demand,min }, y}
$$

where $E_{p, \text { demand,daytime }}$ is the electricity demand during daylight time in the province, assuming roughly the same base load demand during the day as during the night.

The yearly amount of electricity that can be supplied by grid-connected PV in a province, $E_{p, P V, g c, y}$, is:

$$
E_{p, P V, g c, y}=\min \left(E_{p, P V, \text { demand }, y}, E_{p, P V, g c, p o t, y}\right)
$$

The produced electricity by PV per grid-connected capita can be obtained by:

$$
E_{p, P V, g c, c a p, y}=\frac{E_{p, P V, g c, y}}{N_{p, g c}}
$$

Assuming identical electricity consumption per capita in each province, the electricity generated by PV per area type (e.g. urban core) can be determined by multiplying the $E_{p, P V, g c, c a p, y}$ by the population connected to the grid in this area.

$$
E_{p, P V, g c, i, y}=E_{p, P V, g c, c a p, y} \times N_{p, g c, i}
$$

In Table 3-3 some of the input data per province are shown. 
TABle 3-3: InPUT Data PeR PRovince

\begin{tabular}{|c|c|c|c|c|c|c|}
\hline Province & $\begin{array}{r}\mathrm{A}^{*} \\
(\times 1,000) \\
\left(\mathrm{km}^{2}\right)\end{array}$ & $\begin{array}{r}\mathrm{N}^{* *} \\
(\times \mathrm{mln})\end{array}$ & $\begin{array}{l}\mathrm{UR}^{\circ} \\
(\%)\end{array}$ & $\begin{array}{r}\mathrm{N}_{\mathrm{p}, 1}{ }^{\circ 0} \\
(\times 1,000)\end{array}$ & $\begin{array}{l}\mathrm{ER}^{\dagger} \\
(\%)\end{array}$ & $\begin{array}{r}\mathrm{H}^{\dagger \dagger} \\
\left(\mathrm{kWh} / \mathrm{m}^{2}\right. \\
/ \mathrm{d})\end{array}$ \\
\hline Banten & 9.7 & 10.6 & 67 & 3,878 & 74 & 4.8 \\
\hline West Java & 35.4 & 43.1 & 66 & 9,256 & 70 & 4.8 \\
\hline East Java & 47.8 & 37.5 & 48 & 4,832 & 68 & 4.9 \\
\hline Central Java & 32.8 & 32.4 & 46 & 2,823 & 73 & 5.5 \\
\hline Jakarta & 0.7 & 9.6 & 100 & 9,608 & 93 & 4.8 \\
\hline Yogyakarta & 3.1 & 3.5 & 66 & 389 & 71 & 4.8 \\
\hline S. Kalimantan & 38.7 & 3.6 & 42 & 805 & 70 & 4.8 \\
\hline E. Kalimantan & 204.5 & 3.6 & 62 & 1,531 & 59 & 4.8 \\
\hline W. Kalimantan & 147.3 & 4.4 & 30 & 683 & 53 & 5.0 \\
\hline C. Kalimantan & 153.6 & 2.2 & 33 & 201 & 48 & 4.8 \\
\hline Maluku & 46.9 & 1.5 & 37 & 334 & 65 & 5.8 \\
\hline North Maluku & 32.0 & 1.0 & 27 & 192 & 50 & 6.0 \\
\hline Bali & 5.8 & 3.9 & 60 & 789 & 75 & 5.3 \\
\hline WNT & 18.6 & 4.5 & 42 & 515 & 30 & 5.6 \\
\hline ENT & 48.7 & 4.7 & 19 & 316 & 24 & 6.2 \\
\hline S. Sulawesi & 46.7 & 8.0 & 37 & 1,573 & 65 & 5.4 \\
\hline N. Sulawesi & 13.9 & 2.3 & 45 & 681 & 64 & 5.9 \\
\hline Gorontalo & 11.3 & 1.0 & 34 & 174 & 41 & 5.1 \\
\hline S.E. Sulawesi & 38.1 & 2.2 & 27 & 371 & 41 & 4.9 \\
\hline C. Sulawesi & 61.8 & 2.6 & 24 & 310 & 50 & 5.0 \\
\hline W. Sulawesi & 16.8 & 1.2 & 23 & - & 39 & 5.5 \\
\hline W. Sumatra & 42.0 & 4.8 & 39 & 1,201 & 69 & 4.9 \\
\hline N. Sumatra & 73.0 & 13.0 & 49 & 3,124 & 78 & 4.5 \\
\hline S. Sumatra & 91.6 & 7.5 & 36 & 1,798 & 59 & 4.6 \\
\hline Lampung & 34.6 & 7.6 & 26 & 1,016 & 53 & 4.9 \\
\hline Jambi & 50.1 & 3.1 & 31 & 569 & 32 & 4.6 \\
\hline Bangka-Belitung & 16.4 & 1.2 & 49 & 163 & 49 & 4.5 \\
\hline Bengkulu & 19.9 & 1.7 & 31 & 296 & 55 & 4.8 \\
\hline Riau & 87.0 & 5.5 & 39 & 1,056 & 40 & 4.4 \\
\hline Riau Islands & 8.2 & 1.7 & 83 & 1,095 & 53 & 5.1 \\
\hline Aceh & 58.0 & 4.5 & 28 & 509 & 91 & 5.1 \\
\hline West Papua & 97.0 & 0.8 & 30 & 118 & 42 & 5.1 \\
\hline Papua & 319.0 & 2.8 & 26 & 234 & 24 & 5.0 \\
\hline *) & \multicolumn{6}{|c|}{$A$ is the area from Statistics Indonesia [31] } \\
\hline **) & \multicolumn{6}{|c|}{$N$ is the population from Statistics Indonesia [24] } \\
\hline ॰) & \multicolumn{6}{|c|}{$U R$ is the urbanization rate from Statistics Indonesia [24] } \\
\hline$\left.{ }^{\circ}\right)$ & \multicolumn{6}{|c|}{$N_{p, 1}$ is the total of the population living in city districts (kota) [24] } \\
\hline$\dagger)$ & \multicolumn{6}{|c|}{$U R$ is the urbanization rate of the province $[24]$} \\
\hline$\dagger \dagger)$ & \multicolumn{6}{|c|}{$H$ is the average daily irradiation from NASA [64] } \\
\hline
\end{tabular}




\subsubsection{Costs}

To be cost-effective, the levelized cost of energy (LCOE) of grid-connected PV must be lower or equal to the generation cost of electricity with existing technology. The LCOE is calculated according to the method from M. Campbell et al. [96]. To calculate the total cost of the PV system for each type of area $i$, first the annual capacity factor ${ }^{3}, C F_{p, i}$, is determined.

$$
C F_{p, i}=\frac{d_{y} \times \bar{H}_{p, d} \times \eta \times A_{p, g r i d, i} \times P R_{i}}{d_{y} \times h_{d} \times \eta \times A_{p, g r i d, i} \times G_{S T C}}
$$

where $G_{S T C}$ is the irradiance at Standard Test Conditions (STC), which is $1 \mathrm{~kW} / \mathrm{m}^{2}$ and $h_{d}$ is the number of hours per day. Equation (3.15) can be simplified to:

$$
C F_{p, i}=\frac{\bar{H}_{p, d} \times P R_{i}}{h_{d} \times G_{S T C}}
$$

Subsequently, the nominal PV system capacity, $C$, in kilowatt-peak $\left(\mathrm{kW}_{\mathrm{p}}\right)$ per area type (urban, etc.) can be determined:

$$
C_{p, i}=\frac{E_{p, P V, i} \times 10^{6}}{d_{y} \times h_{d} \times C F_{p, i}}
$$

The initial investment, $C A P E X_{p, i}$, for each area type can be calculated as follows:

$$
C A P E X_{p, i}=C_{p, i} \times C A P E X_{C}
$$

where the installed system price (including BOS), $C A P E X_{C}$, is in $\$ / \mathrm{kW}_{\mathrm{p}}$.

$$
R V_{p, i}=C A P E X_{p, i} \times R V R
$$

where $R V_{p, i}$ is the residual value of the PV system after its lifetime in province $p$ and area type $i$ and $R V R$ is the residual value rate: A percentage of the initial investment representing its salvage value.

The annual operation costs $A O$ are determined as follows:

$$
A O_{p, i}=C_{p, i} \times A O_{C}
$$

where $A O_{C}$ is the annual operation cost per installed capacity in $\$ / \mathrm{kW}$.

\footnotetext{
${ }^{3}$ The annual capacity factor is defined as the annual kilowatt-hours generated for each kilowatt AC of peak capacity $\left(\mathrm{kWh} / \mathrm{kW}_{\mathrm{p}}\right)$ divided by the number of hours in a year.
} 
The annual depreciation $D P$ is calculated according to the straight line method:

$$
D P_{p, i}=\frac{C A P E X_{p, i}-R V_{p, i}}{L T}
$$

where $L T$ is the lifetime of the PV system.

Next, the LCOE is calculated:

$$
L C O E_{p, i}=\frac{C A P E X_{p, i}-\sum_{n=1}^{L T} \frac{D P_{p, i}}{(1+D R)^{n}} \times(T R)+\sum_{n=1}^{L T} \frac{A O_{p, i}}{(1+D R)^{n}} \times(1-T R)-\frac{R V_{p, i}}{(1+D R)^{n}}}{\sum_{n=1}^{L T} \frac{E_{p, P V, i} \times(1-S D R)^{n}}{(1+D R)^{n}}}
$$

where $n$ is the year, $T R$ is the tax rate, $D R$ the discount rate and $S D R$ the system degradation rate.

In Table 3-4 the values used as input for the model are shown. The lifetime of the PV system is assumed to be 25 years. The discount rate is based on the rate of the central bank of Indonesia [97]. The system degradation rate is assumed to be $0.5 \%$ [98]. The system price of $4 \$ / W_{p}$ is based on a PV module price of about $2 \$ / W_{p}$ [99], which in Indonesia contributes for roughly $50 \%$ to the total system price including BOS, installation and power electronics [100].

TABLE 3-4: ASSUMPTIONS FOR LCOE CALCULATION

\begin{tabular}{lrl}
\hline Variable & Value & Unit \\
\hline Lifetime $(L T)$ & 25 & years \\
\hline Annual operations $\left(A O_{C}\right)$ & 15 & $\$ / \mathrm{kW}_{\mathrm{p}}$ \\
\hline Residual value rate $(R V R)$ & 0.5 & $\%$ \\
\hline Discount rate $(D R)$ & 5.75 & $\%$ \\
\hline System degradation rate $(S D R)$ & 0.5 & $\%$ \\
\hline System price $\left(C A P E X_{C}\right)$ & 4,000 & $\$ / \mathrm{kW}_{\mathrm{p}}$ \\
\hline Tax rate $(T R)$ & 25 & $\%$ \\
\hline
\end{tabular}

\subsubsection{PLN's generation cost}

To determine the cost-effectiveness of grid-connected PV systems, it is necessary to know PLN's generation cost of grid electricity. Statistics from PLN show the overall generation costs and it includes average cost per generation type (e.g. hydro, steam, diesel), however a breakdown by province is lacking [25]. Nevertheless, many other statistics are presented per 
region/province, such as the amount of electricity production per generation type and average fuel cost.

A report from the World Bank from 2005 presents the costs of supply for a number of regions in Indonesia [8], which show large deviations among the regions, however these values are probably not representative anymore. Comparing PLN's average generation cost of a kWh in 2005 with 2010 shows an increase of 69\% [25]. Simply increasing the average generation cost of a $\mathrm{kWh}$ per region from 2005 with this average increase does not represent the actual situation due to large differences in the amount of electricity production and in the type of generation per province. Therefore is decided to calculate the average generation cost per province based on the various related statistics from PLN.

A thorough analysis of the statistics has been carried out to determine the cost of a $\mathrm{kWh}$ per province. The methodology includes the total electricity production per province. Overall generation costs - which include maintenance, depreciation, personnel and others per generation type are divided in proportion to the energy production per generation type per province. The total fuel cost per generation type is obtained in a similar way.

PLN provides the data of the production, losses and consumption of electricity per region (PLN operational unit), which is sometimes equal to one or more provinces and sometimes only a part of it. Besides, electricity generated in a particular province can be consumed in a neighboring province. Therefore, this short analysis on energy losses is not carried out for each province separately, but either for (a) the smallest region defined by PLN or for (b) a region consisting of interconnected operational units and/or provinces.

The total electricity production of $170 \mathrm{TWh}$ in Indonesia consists of $123 \mathrm{TWh}$ generated by PLN itself and 46 TWh which is purchased or rented. Since in some regions the majority of the electricity is purchased or rented, the actual cost of electricity can significantly be influenced by this. Since only the total cost of the electricity purchase and rented diesel for Indonesia is known, this amount has been divided in proportion to the rented and purchased electricity use per region and is corrected for the difference in fuel price per region.

In Fig. 3.4 PLN's generation cost and residential selling price in $\$ / \mathrm{kWh}$ are shown for the regions in Indonesia. The generation cost of PLN as presented in the report from the World Bank is shown as well for comparison. Besides, the generation costs over the year 2010 are shown for PLN only and for the total electricity production including rented and purchased electricity. The generation cost reported by the World Bank includes power purchase as well, but the study lacks more detailed information about the calculations [8]. Because of the complexity of the underlying data, the 2005 values have not been corrected for inflation. 


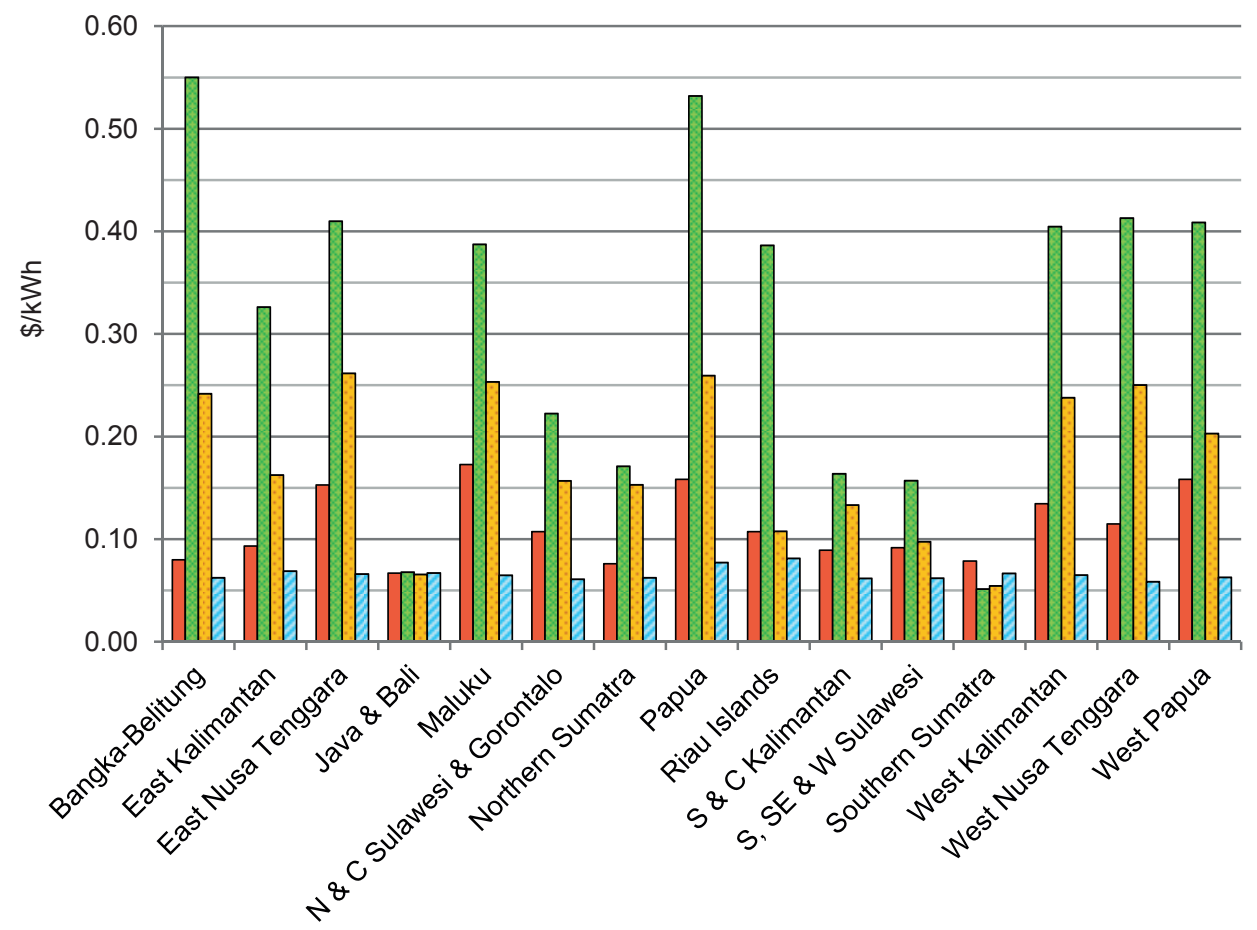

口PLN $2005 \square$ PLN 2010 (PLN only) घPLN 2010 (total) $\quad$ Residential price 2010

Fig. 3.4. Average electricity generation cost and residential selling price in $\$ / \mathrm{kWh}$ for various regions in Indonesia.

From Fig. 3.4 can be seen that in most regions the generation cost is significant higher than the average selling price for residential customers. Based on the total generation cost and the residential selling price per province, PLN receives only very limited revenue in the provinces Jakarta, Yogyakarta, Bali and the Southern Sumatran provinces South Sumatra, Lampung, Jambi and Bengkulu.

Furthermore, it can be seen that the generation cost of PLN only is significantly higher compared with the total electricity cost in some regions. This can mainly be explained by the high share of electricity generation by diesel in these regions. In the provinces Maluku, Bangka-Belitung and Riau-islands this is $100 \%$, in West and East Nusa Tenggara diesel accounts for $98 \%$ of the electricity generation and in Papua and West-Papua this is respectively $95 \%$ and $93 \%$. With an average generation cost by diesel of $0.48 \$ / \mathrm{kWh}$ in Indonesia in 2010 [25], the high generation cost of electricity by PLN in these regions can be explained. The lower electricity cost caused by including the rented and purchased electricity suggests that these generators are installed in more favorable locations in which the generators can run more efficiently, although the cost of electricity remains high with values around $0.25 \$ / \mathrm{kWh}$. 


\subsection{Grid-connected PV potential and costs}

\subsubsection{Electricity}

The total potential of grid-connected PV in Indonesia, $E_{P V, g c, p o t, y}$, is estimated to be 1,492 TWh, which corresponds to about 10 times the total electricity demand of 2010. The share of this potential that is actual possible to develop taking the electricity demand into account, is $26 \%, 5 \%$ and $0.5 \%$ for urban cores, suburbs and villages, respectively.

The potential of grid-connected PV limited by the actual electricity demand, $E_{P V, g c, y}$, is estimated to bel $37 \mathrm{TWh} /$ year, which is about $26 \%$ of the total electricity consumption over 2010 according to PLN [25]. Of the total electricity generated by grid-connected PV, $40 \%$ can be produced in the urban cores, $43 \%$ in the suburbs and $17 \%$ in villages.

The available area for solar PV is not a limiting factor in most provinces, only in the Jakarta region the calculated potential can be completely used, in other provinces this is not even close. Based on an average capacity factor of 16\%, the amount of $37 \mathrm{TWh} /$ year could be supplied by about $28 \mathrm{GW}_{\mathrm{p}}$ installed PV capacity, with a total required land area of about $190 \mathrm{~km}^{2}$, assuming 15\% module efficiency and a PR of 75\%. The total potential, $E_{P V, g c, p o t, y}$, could be supplied by about $1,100 \mathrm{GW}_{\mathrm{p}}$, requiring a land area of $7,570 \mathrm{~km}^{2}$ corresponding to $0.5 \%$ of the land area of Indonesia.

\subsection{2 $\mathrm{CO}_{2}$ reduction potential}

PV has an average $\mathrm{CO}_{2}$ emission of $45 \mathrm{~g} \mathrm{CO}_{2}$-eq/kWh [43], while coal and diesel have an average emission of 1,000 and $800 \mathrm{~g} \mathrm{CO}_{2}$-eq/kWh, respectively [101]. In Table 3-5 the grid emission factors ${ }^{4}$ of Indonesia are shown.

TABLE 3-5: $\mathrm{CO}_{2}$ GRID EMISSION FACTORS

\begin{tabular}{|c|c|}
\hline Grid Name & $\begin{array}{l}\mathrm{EF}^{+} \\
\text {(ton } \mathrm{CO}_{2} \text {-eq } / \mathrm{MWh}_{\mathrm{e}} \text { ) }\end{array}$ \\
\hline Java-Madura-Bali (Jamali) $^{*}$ & 0.73 \\
\hline Sumatra $^{*}$ & 0.75 \\
\hline West Kalimantan $^{*}$ & 0.73 \\
\hline South and Central Kalimantan* & 0.96 \\
\hline East Kalimantan $^{*}$ & 0.86 \\
\hline South Sulawesi, West Sulawesi* & 0.61 \\
\hline N. Sulawesi, Gorontalo, C. Sulawesi ${ }^{\dagger}$ & 0.16 \\
\hline Southeast Sulawesi ${ }^{\dagger}$ & 0.27 \\
\hline
\end{tabular}

\footnotetext{
${ }^{4}$ The grid emission factor is defined as the total annual $\mathrm{CO}_{2}$ emissions from power plants connected to the grid divided by the total annual electricity produced by these power plants
} 
For other regions without a large electricity grid, there is assumed that the power is generated based on diesel with an emission factor of 0.8 ton $\mathrm{CO}_{2}$-eq/MWhe As such 26 ton $\mathrm{CO}_{2}$-eq/year could be reduced by PV systems.

\subsubsection{LCOE}

The LCOE of grid-connected PV has been calculated for each province. The LCOE for all provinces range from 0.15 to $0.22 \$ / \mathrm{kWh}$ for urban areas and from 0.17 to $0.24 \$ / \mathrm{kWh}$ for rural areas.

Compared with the average subsidized residential electricity tariff of $0.07 \$ / \mathrm{kWh}^{5}(0.10$ $\$ / \mathrm{kWh}$ for business) [25], grid-connected PV is not cost-effective in any province yet. However, the real generation cost of PLN is on average $0.09 \$ / \mathrm{kWh}$ and ranging from 0.05 to $0.55 \$ / \mathrm{kWh}$, as can be seen from Fig. 3.4. Besides, PLN's total production cost is on average $0.08 \$ / \mathrm{kWh}$ and ranges from $0.05-0.26 \$ / \mathrm{kWh}$. Fig. 3.5 shows the difference in LCOE of grid-connected PV and PLN's total production costs for suburban areas for each province. As can be seen, in some eastern provinces of Indonesia the LCOE of solar PV is lower than the actual electricity production cost by PLN. The cost-effective potential of PV systems is $489 \mathrm{MW}_{\mathrm{p}}$ which is less than $2 \%$ of the total demand limited potential of gridconnected PV systems. In the nearby future cost-effectiveness will be most likely possible for the major part of Indonesia due to a rapid reduction of costs of PV modules and BOS components as well as steadily increasing prices of fossil fuels in Indonesia.

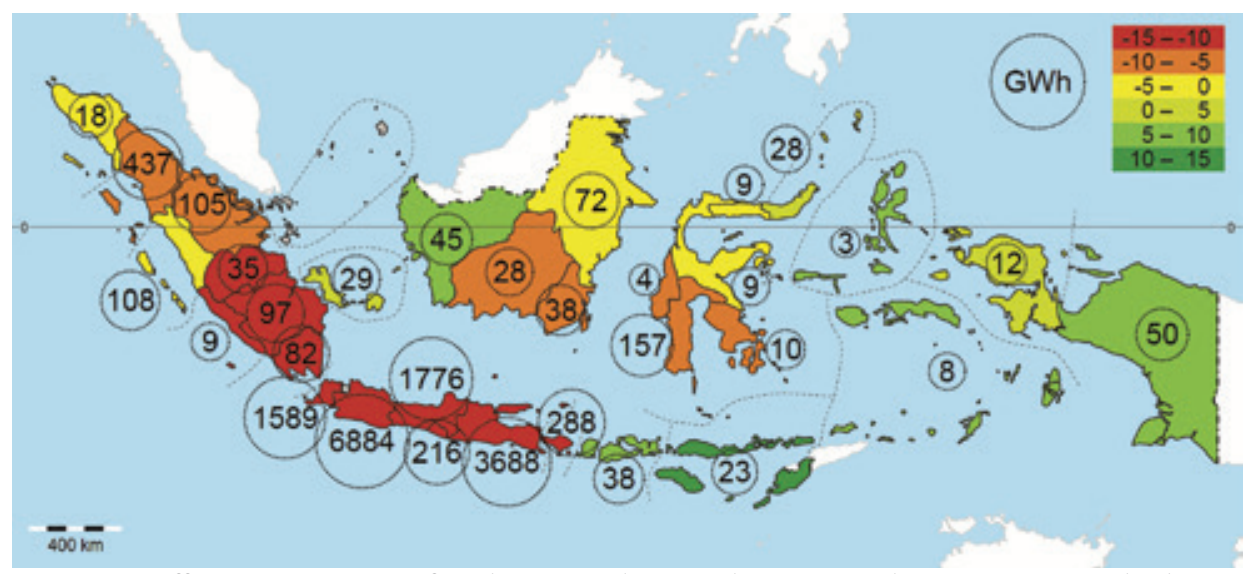

Fig. 3.5. Difference in LCOE of grid-connected PV and PLN's production costs in suburbs per province of Indonesia. The colors show the difference in calculated LCOE of grid-connected PV in $\$ / \mathrm{kWh}$. Provinces shown in grey do not have grid-connected suburban areas. The dotted circles indicate the potential amount of electricity generation by grid-connected PV in GWh/year.

In Fig. 3.5 the difference in LCOE is based on the total electricity production cost (i.e. including rented and purchased electricity). Since PLN's generation cost is much higher in

\footnotetext{
${ }^{5}$ Based on values for 2010
} 
some provinces, the LCOE of grid-connected PV systems for the three distinguished areas is compared with the range of the electricity generation cost for each in the provinces, the results are shown in Fig. 3.6.

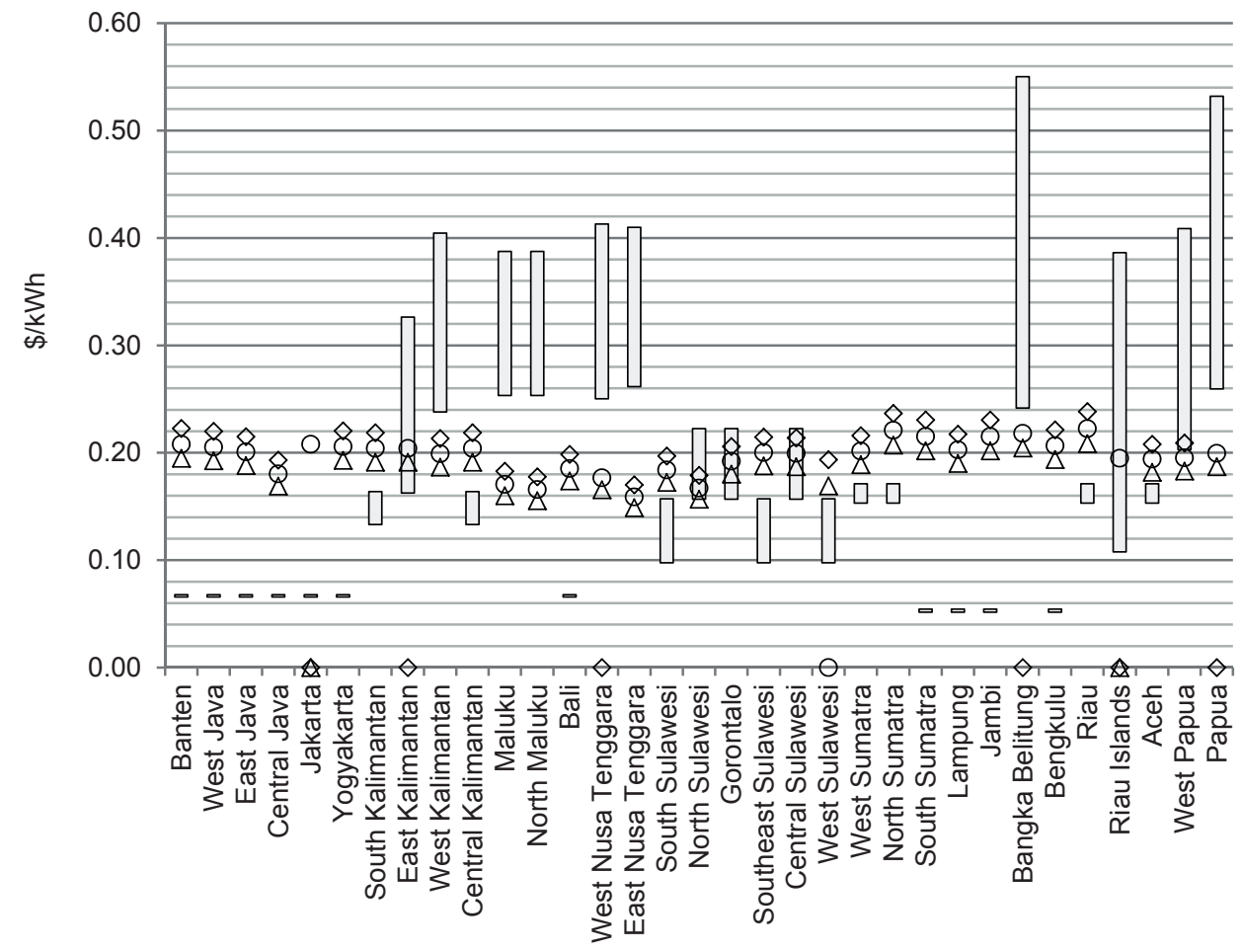

口actual electricity generation $\quad \mathrm{PV}$ urban core $\quad \triangle \mathrm{PV}$ suburbs $\diamond \mathrm{PV}$ rural villages

Fig. 3.6. LCOE of grid-connected PV systems in different areas compared with the electricity generation cost range based on PLN only and PLN total.

From Fig. 3.6 can be seen that the difference in LCOE between PV systems and the actual electricity generation varies greatly. The largest difference can be found in the province of Bangka Belitung in which electricity from grid-connected PV can be 0.35 $\$ / \mathrm{kWh}$ cheaper than existing electricity generation.

\subsubsection{Sensitivity analysis}

To determine the variables that have a significant influence on the LCOE a sensitivity analysis is carried out. In Table 3-6 the results are shown, the values in $\$ / \mathrm{kWh}$ show the average LCOE in Indonesia for different input values. 
TABLE 3-6: RESULTS SENSITIVITY ANALYSIS OF THE AVERAGE LCOE FOR URBAN CORES IN \$/KWH

\begin{tabular}{lcccc}
\hline Urban core & $-50 \%$ & $0 \%$ & $50 \%$ & $200 \%$ \\
\hline Lifetime $(L T)$ & 0.287 & 0.197 & 0.177 & 0.168 \\
\hline PV system price $($ CAPEX) & 0.103 & 0.197 & 0.291 & 0.574 \\
\hline Discount rate $(D R)$ & 0.137 & 0.197 & 0.264 & 0.492 \\
\hline System degradation rate $(S D R)$ & 0.192 & 0.197 & 0.202 & 0.217 \\
\hline Annual operations $(A O)$ & 0.193 & 0.197 & 0.201 & 0.214 \\
\hline Residual value $(R V)$ & 0.205 & 0.197 & 0.189 & 0.167 \\
\hline Tax rate $(T R)$ & 0.214 & 0.197 & 0.180 & 0.130 \\
\hline
\end{tabular}

TABLE 3-7: RESULTS SENSITIVITY ANALYSIS OF THE AVERAGE LCOE FOR SUBURBS IN $\$ / \mathrm{KWH}$

\begin{tabular}{lcccc}
\hline Suburb & \multicolumn{1}{c}{$-50 \%$} & $0 \%$ & $50 \%$ & $200 \%$ \\
\hline Lifetime $(L T)$ & 0.268 & 0.184 & 0.165 & 0.156 \\
\hline PV system price $(C A P E X)$ & 0.096 & 0.184 & 0.272 & 0.536 \\
\hline Discount rate $(D R)$ & 0.128 & 0.184 & 0.246 & 0.460 \\
\hline System degradation rate $(S D R)$ & 0.179 & 0.184 & 0.189 & 0.203 \\
\hline Annual operations $(A O)$ & 0.180 & 0.184 & 0.188 & 0.200 \\
\hline Residual value $(R V)$ & 0.191 & 0.184 & 0.177 & 0.156 \\
\hline Tax rate $(T R)$ & 0.199 & 0.184 & 0.168 & 0.122 \\
\hline
\end{tabular}

TABLE 3-8: RESULTS SENSITIVITY ANALYSIS OF THE AVERAGE LCOE FOR VILLAGES IN $\$ / \mathrm{KWH}$

\begin{tabular}{lcccr}
\hline Village & \multicolumn{1}{l}{-50\% } & \multicolumn{1}{l}{$0 \%$} & \multicolumn{1}{l}{$50 \%$} & $200 \%$ \\
\hline Lifetime $(L T)$ & 0.305 & 0.210 & 0.189 & 0.178 \\
\hline System price $(C A P E X)$ & 0.109 & 0.210 & 0.310 & 0.611 \\
\hline Discount rate $(D R)$ & 0.146 & 0.210 & 0.281 & 0.524 \\
\hline System degradation rate $(S D R)$ & 0.204 & 0.210 & 0.215 & 0.231 \\
\hline Annual operations $(A O)$ & 0.205 & 0.210 & 0.214 & 0.228 \\
\hline Residual value $(R V)$ & 0.218 & 0.210 & 0.202 & 0.177 \\
\hline Tax rate $(T R)$ & 0.227 & 0.210 & 0.192 & 0.139 \\
\hline
\end{tabular}


As can be seen, the implemented LCOE model is most sensitive to the system price and in a lesser extent to the discount rate. If the system price drops with 50\%, the LCOE values of PV are competitive to PLN's electricity production costs in many provinces.

The differences among Table 3-6 - Table 3-8 can be attributed to the various selected performance factors of the PV system for each area type.

Since the calculated potential of grid-connected PV is vast, the model is not very sensitive to changes in population densities of each classified area, which only affects the potential area and not the LCOE.

\subsubsection{Tax incentives}

The Indonesian government gives tax incentives to support investments in the renewable energy sector through regulation 21/2010 from Ministry of Finance Republic Indonesia [104]. The regulation provides for a reduction of net income up to $30 \%$ of the amount invested for six years (5\% per year) and accelerated depreciation and amortization.

Taking this investment credit into account and applying the double declining balance method to calculate the annually deprecation, the LCOE of PV systems decreases with 0.015 to $0.024 \$ / \mathrm{kWh}$. The LCOE varies per province between $0.14-0.20 \$ / \mathrm{kWh}, 0.13$ $-0.19 \$ / \mathrm{kWh}$ and $0.15-0.21 \$ / \mathrm{kWh}$, for urban cores, suburbs and villages, respectively.

\subsubsection{Future outlook}

It is expected that the PV system price will further decrease in the coming years because of higher module efficiencies and lower production costs due to economies of scale. In addition the Indonesian government is preparing a new pricing regulation for solar PV. The new price for electricity from solar power plants will be around IDR $^{6} 1,880$ (USD 0.20 ) to IDR 3,135 (USD 0.33) per $\mathrm{kWh}$, depending on the location [105]. With this feed-in tariff, investments in grid-connected PV systems will be profitable everywhere in Indonesia. Furthermore, PLN's electricity generation costs are expected to rise due to increasing fossil fuel prices, making PV more cost competitive.

To determine the future LCOE of PV for each province in Indonesia, the system price is assumed to reach $2 \$ / W_{\mathrm{p}}$ around the year 2020 [106]. Other aspects that could influence the benchmarking of costs, such as for instance increasing oil prices or changes of discount rate, are not taken into account. In Fig. 3.7 - Fig. 3.9 the results are shown for the urban cores, suburbs and villages, respectively. The LCOE is subtracted from the LCOE based on PLN's total electricity production cost for each province.

\footnotetext{
${ }^{6}$ Indonesian rupiah, the exchange rate used for all calculations in this study is 1 USD $=9,624.00$ IDR as of 2012-11-13 17:00 UTC, source: www.xe.com
} 


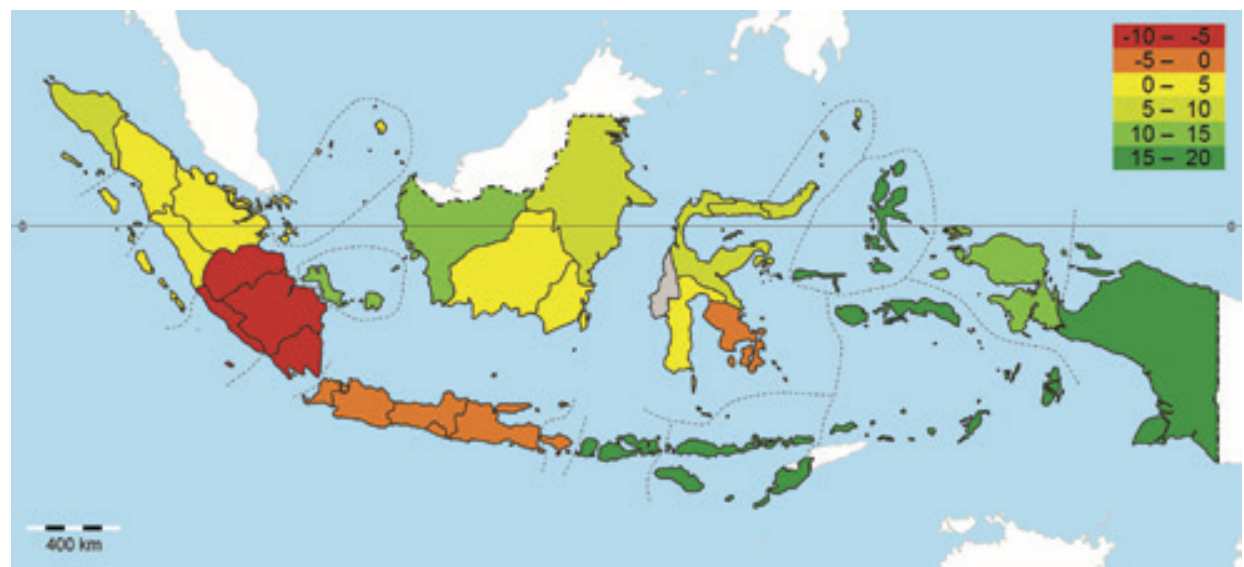

Fig. 3.7. Difference in LCOE for urban cores per province of Indonesia. The colors show the difference in PLN's production cost and the calculated LCOE of grid-connected PV. Values in $\$ / \mathrm{kWh}$ for a system price of $2 \$ / \mathrm{W}_{\mathrm{p}}$. Positive values indicate that the LCOE is lower compared with the generation cost. Provinces shown in grey do not have grid-connected urban core areas.

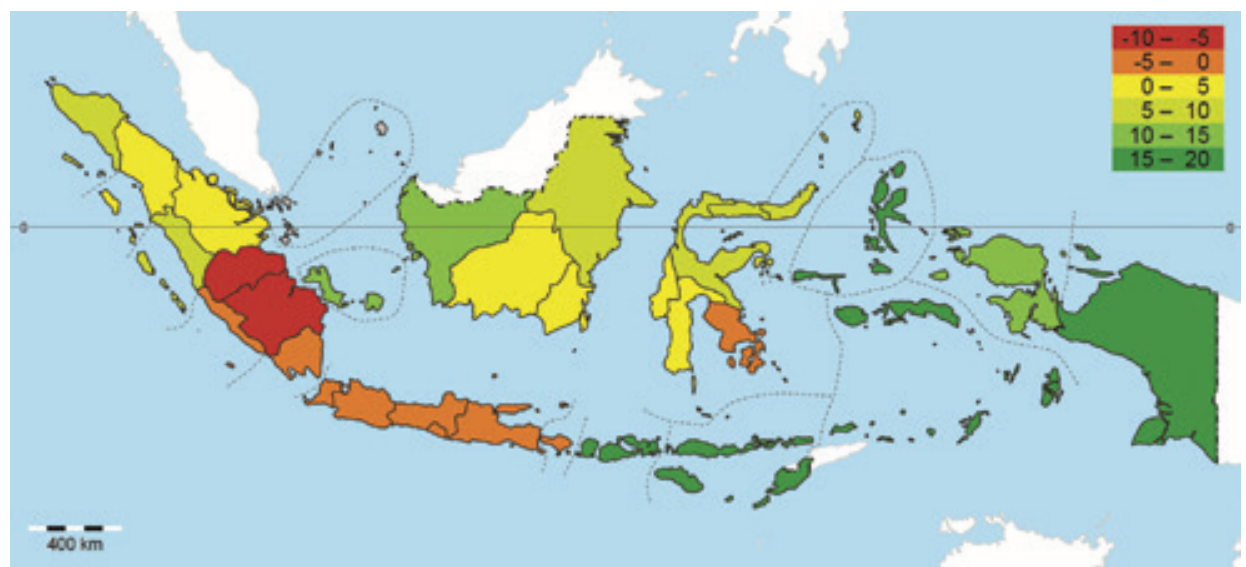

Fig. 3.8. Difference in LCOE for suburbs per province of Indonesia. The colors show the difference in PLN's production cost and the calculated LCOE of grid-connected PV. Values in $\$ / \mathrm{kWh}$ for a system price of $2 \$ / W_{p}$. Positive values indicate that the LCOE is lower compared with the production cost of PLN. Provinces shown in grey do not have grid-connected suburb areas.

As can be seen from Fig. 3.7 - Fig. 3.9, the provinces wherein PV gets cheaper than PLN's production costs are mainly the eastern provinces. However, with the new subsidy scheme, grid-connected PV will be both technically and economically feasible in all Indonesian provinces. 


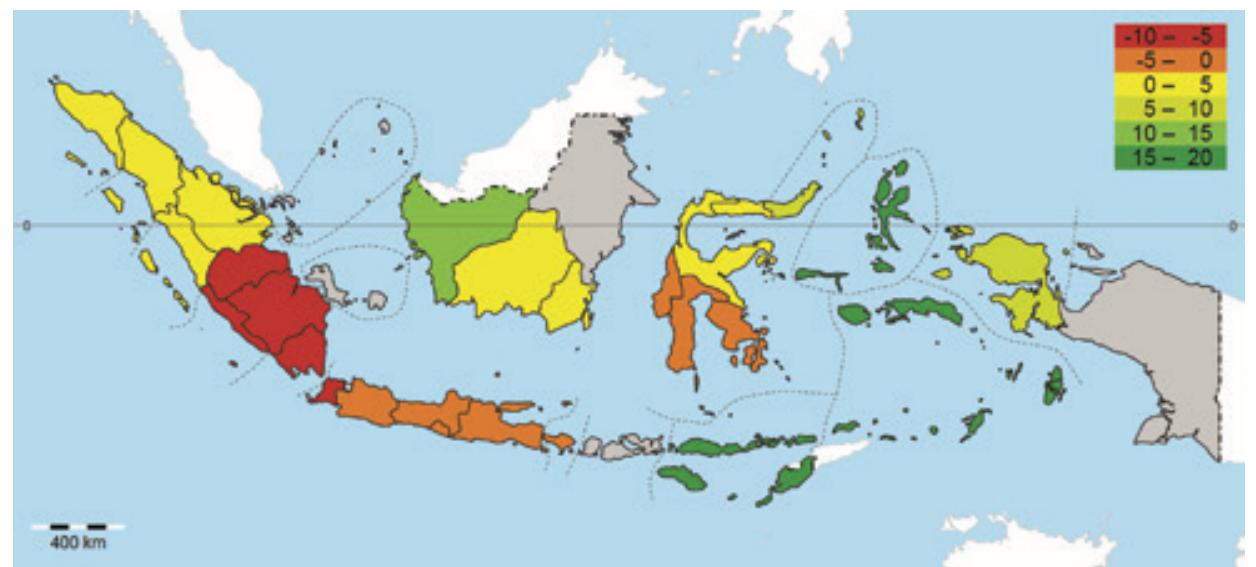

Fig. 3.9. Difference in LCOE for rural areas per province of Indonesia. The colors show the difference in PLN's production cost and the calculated LCOE of grid-connected PV. Values in $\$ / \mathrm{kWh}$ for a system price of $2 \$ / \mathrm{W}_{\mathrm{p}}$. Positive values indicate that the LCOE is lower compared with the production cost of PLN. Provinces shown in grey do not have grid-connected rural areas.

In Fig. 3.10 a similar map is shown for a system price of $1 \$ / W_{p}$ for suburban areas, with this system price grid-connected PV is cost-effective in most provinces of Indonesia. Gridparity for all areas in all provinces in Indonesia is reached with a system price of $0.80 \$ / \mathrm{W}_{\mathrm{p}}$, assuming all other variables remain the same.

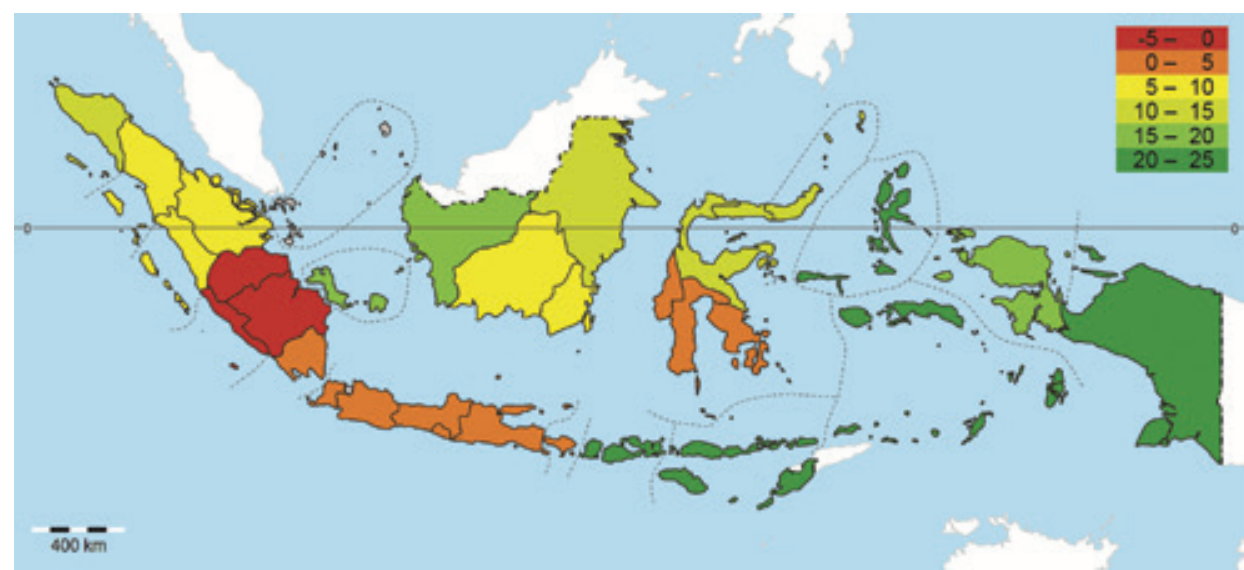

Fig. 3.10. Difference in LCOE for suburbs per province of Indonesia. The colors show the difference in PLN's production cost and the calculated LCOE of grid-connected PV. Values in $\$ / \mathrm{kWh}$ for a system price of $1 \$ / \mathrm{W}_{\mathrm{p}}$. Positive values indicate that the LCOE is lower compared with the production cost of PLN. Provinces shown in grey do not have grid-connected suburb areas. 


\subsection{Model limitations}

In the model presented this is related to the population size with grid connection, so this maximum potential increases with increasing electrification rates. The electricity demand grows about $9 \%$ per annum, which means that the amount of electricity that can be generated by PV could potentially follow this trend.

The LCOE values for each province are determined for urban cores, suburban areas and rural villages. Since the LCOE is sensitive to the system price and the system price is assumed to be constant for each province, the actual LCOE can be influenced by transportation costs of the PV system to remote provinces. These costs are not taken into account yet, according to the sensitivity analysis an increase of the system price by $50 \%$ leads to an increase of the LCOE by about $0.10 \$ / \mathrm{kWh}$ corresponding to an increase of $48 \%$. The remoteness of the location can influence the annual operation costs in a same way as well, however the LCOE is found to be less sensitive to these costs.

The illegal electricity demand (see Appendix A) is included in the electricity demand of grid-connected PV. As such, it would not influence significantly the potential of gridconnected PV systems, however the illegal connections would mean that the electrification rates of PLN are higher in reality, resulting in a larger potential area for PV systems.

The method presented in this study to determine the area with an electricity grid assumes that there is no grid at all in rural areas, which is probably not the case in practice, instead the electricity grid in rural areas would likely be very dispersed.

\subsection{Conclusions}

The total potential of grid-connected PV systems in Indonesia, based on the present population size and land availability factors, is $1,100 \mathrm{GW}_{\mathrm{p}}$, generating about 1,492 TWh which is 10 times more than the electricity consumed in Indonesia in 2010.

Taking restrictions of the present electricity demand during day-time and a minimal base load of conventional power systems into account, the total potential is about $28 \mathrm{GW}_{\mathrm{p}}$, generating $37 \mathrm{TWh} /$ year, which is about $25 \%$ of the total electricity consumption in Indonesia in 2010. This is a realistic number.

Compared with the energy potentials of other renewables in Indonesia, the present potential of grid-connected PV is similar to the potential of geothermal energy and roughly the half of the potential for biomass.

The LCOE of grid-connected PV has been calculated for each province. The LCOE for all provinces range from 0.15 to $0.22 \$ / \mathrm{kWh}$ for urban areas and from 0.17 to $0.24 \$ / \mathrm{kWh}$ for rural areas.

Based on a system price of $4 \$ / W_{p}$, PV cannot compete yet with the retail prices of electricity which are subsidized by the government. However, in some provinces, especially 
located in the eastern part of Indonesia, the LCOE of grid-connected PV is already costeffective.

According to the sensitivity analysis, the major factors of influence on the LCOE are the system price and the discount rate. It is shown that with a system price of $2 \$ / W_{p} P V$ systems are cost-effective for eastern Indonesia. At $0.80 \$ / \mathrm{W}_{\mathrm{p}}$ grid-parity has reached for all areas in all provinces, assuming all other variables remain constant.

Nevertheless with the feed-in tariff for PV energy, expected decline of PV system costs and projected increase of fossil fuel cost, grid-connected PV gets cost-effective in most parts of Indonesia.

From this study can be concluded that grid-connected PV could play a key role in solving several energy related issues in Indonesia. It can help to increase electrification rates on remote islands and to decrease the dependency on fossil fuels.

Since the method is based on commonly available data (e.g. urbanization rate, electrification rate population), this method could be useful for other developing countries with a lack of grid distribution data as well. 


\section{4}

\section{The potential and costs of off-grid PV systems in Indonesia}

In this chapter a methodology is developed to model the potential and costs of off-grid PV systems in Indonesia. The cost-effectiveness of these systems is evaluated against the actual generation cost of electricity by diesel generators, which are commonly used in these off-grid areas.

\subsection{Introduction}

The potential of off-grid PV systems can complement the overall potential of PV systems in Indonesia. The potential of off-grid PV systems in Indonesia has not been modeled in detail yet. From the literature discussed before in section 2.3, it seems that still some improvements can be made to existing approaches towards assessing the potential of offgrid PV. Namely, (a) including areas without electricity access, (b) focus on the specific situation in Indonesia, (c) including geographic variations of settlements. Therefore a similar methodology as in the previous chapter is proposed, leading to cumulative numbers for nominal power installed off-grid PV systems, their LCOE and the relative financial benefits compared with diesel generators for each province. The method is largely determined by available irradiation, population density, residential electricity demand and grid-penetration.

\subsubsection{Research questions}

The main research question in this study is: What is the potential and cost-effectiveness of off-grid PV systems in each of the provinces of Indonesia?

The main research question can be divided into the following sub questions:

- How many households lack access to electricity per province?

- What would be the electricity demand of these households if they would have access to electricity?

- What is the population density of the population lacking access to electricity?

- Which part of the non-electrified areas can be served by a local micro-grid? 
- What is the levelized cost of electricity of off-grid PV systems in the various provinces?

- What is the levelized cost of electricity of diesel generators in the different provinces of Indonesia?

- What is the potential for off-grid PV systems per province?

- In which provinces off-grid PV systems will be cost-effective?

\subsubsection{Outline}

In section 4.2 the applied methodology will be described. Section 4.3 presents the results, including a sensitivity analysis. A validation will be presented in a separate section, section 4.4. This is followed by the discussion in section 4.5 and finally in section 4.6 the conclusions are presented.

\subsection{Modeling the potential of off-grid PV systems}

In this section the applied methodology to answer these above-mentioned questions will be described. This study examines the potential of off-grid PV systems for each of the 33 provinces $^{7}$. Since large geographical differences exist in Indonesia and most relevant data are available on a provincial level, a mathematical model has been developed to determine this potential based on among others: population density, urbanization rate, irradiation, electrification rate and electricity demand. Here the method will be explained.

Due to data availability the methodology is based on data from 2010 for ease of comparison among different information sources.

It is assumed that urban households which lack access to electricity will be at PLN's waiting list and will get connected to the grid in the near future. Besides, in these urban areas grid extension is assumed to be the most cost-effective electrification option, therefore the scope of this study is limited to the rural households without access to electricity. As such, the province of Jakarta is excluded from this analysis, since it contains no rural households at all, leaving only 32 provinces left for this study.

Since other renewable energy sources, such as geothermal plants, large hydropower, wind turbines and modern biomass installations are mainly grid-connected, they do not influence the off-grid potential. Only the use of small-scale wind turbines and micro-hydropower systems can be applied in off-grid systems and can as such influence the off-grid potential of PV systems. Since the potential of wind energy is rather low due to the prevailing low wind speeds in Indonesia, varying between $2-6 \mathrm{~m} / \mathrm{s}$ on average [58], there is assumed that the off-grid potential of wind energy can be neglected. Micro-hydropower has a strong

\footnotetext{
${ }^{7}$ In 2012 the northern part of the province of East Kalimantan has formed its own province: North Kalimantan. Since the study is based on data from 2010, the former province of East Kalimantan has been applied.
} 
seasonal dependency due to the monsoon while solar PV is a constant energy source the whole year through, besides the potential of micro-hydropower is highly location dependent, therefore it is not included in the model.

To calculate the actual potential of off-grid PV systems the following general assumptions have been made:

(i) Other renewable energy technologies such as hydropower, geothermal energy, wind energy or biomass are not taken into account.

(ii) Rural electricity demand is a dominant factor.

(iii) Off-grid PV systems are only viable in areas lacking grid-connection

(iv) The model is based on a provincial level, so regional variations inside the province (i.e. at district level) itself are outside the scope of this study.

In order to determine the potential and costs of off-grid PV systems, the modeling approach is divided into several steps, as schematically shown in Fig. 4.1. Besides, the figure shows the sections in which the assumptions and equations related to each step are described. 


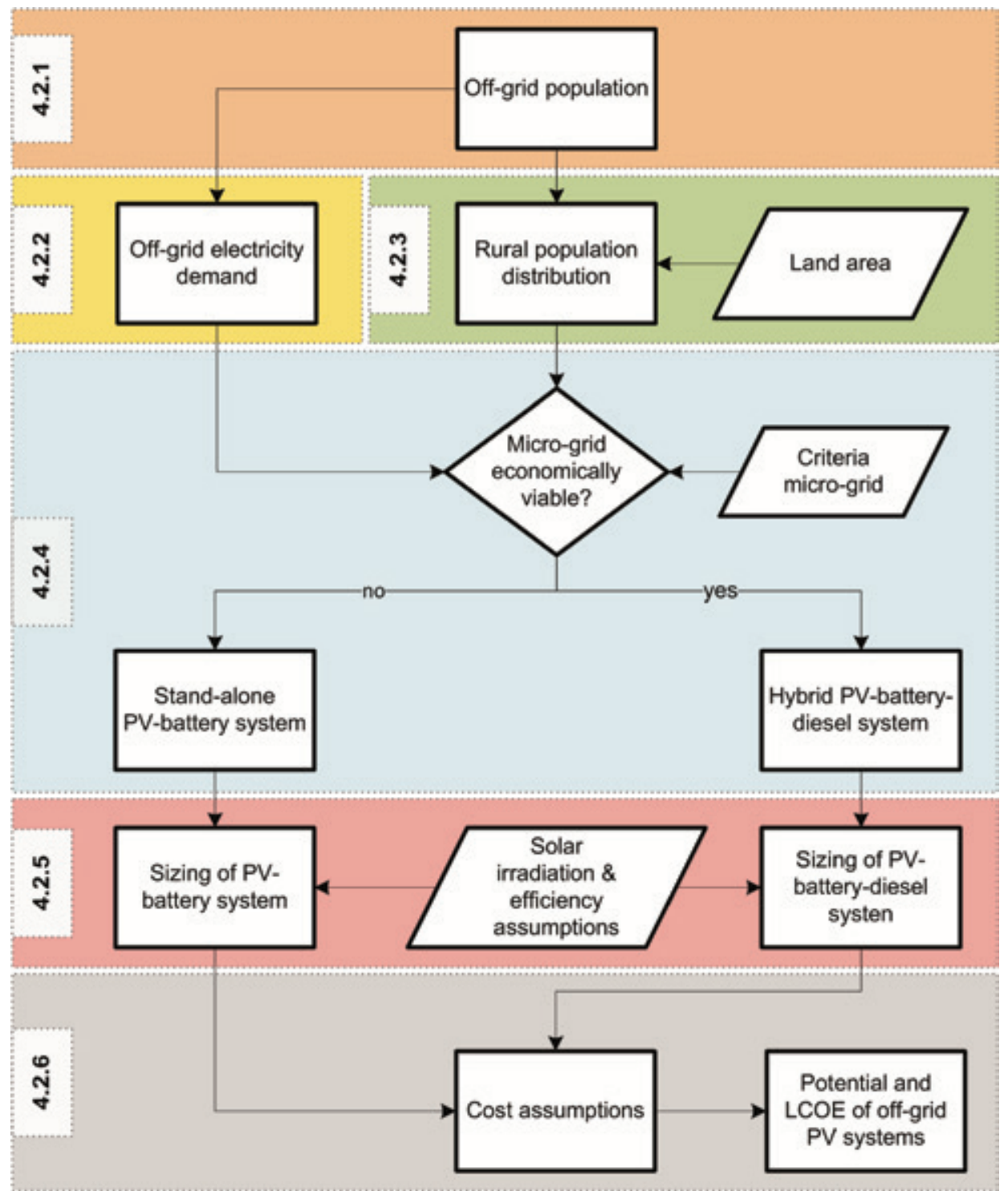

Fig. 4.1. Schematic diagram of the methodology with references to the section numbers.

In the next subsections the assumptions and equations applied in the calculations will be explained for each step in the method.

\subsubsection{Off-grid population}

Data on rural electrification rates of households are limited, however it is assumed that the information about the primary source of lighting per household, as presented earlier in section 2.1 and Fig. 2.2, gives a good representation of the households with access to electricity. This methodology is used in a similar study as well [69]. 
From these data can be concluded that in rural areas $17 \%$ of homes do not have access to the national grid and $11 \%$ do not have access to electricity at all. These are averages for Indonesia, locally these numbers can vary significantly. Namely from $2 \%$ of the rural households in Java to $80 \%$ in Papua lacking access to electricity, as can be seen in Fig. 4.2.

This study on off-grid PV systems focuses on the rural households without electricity, most of these households live in the provinces East Nusa Tenggara (ENT) and Papua, with respectively $63 \%$ of the 820 thousand rural homes and $80 \%$ of the 490 thousand rural homes, see Fig. 4.2 and Fig. 4.3. In contrast, the provinces at Java show low shares of these rural households lacking electricity access.

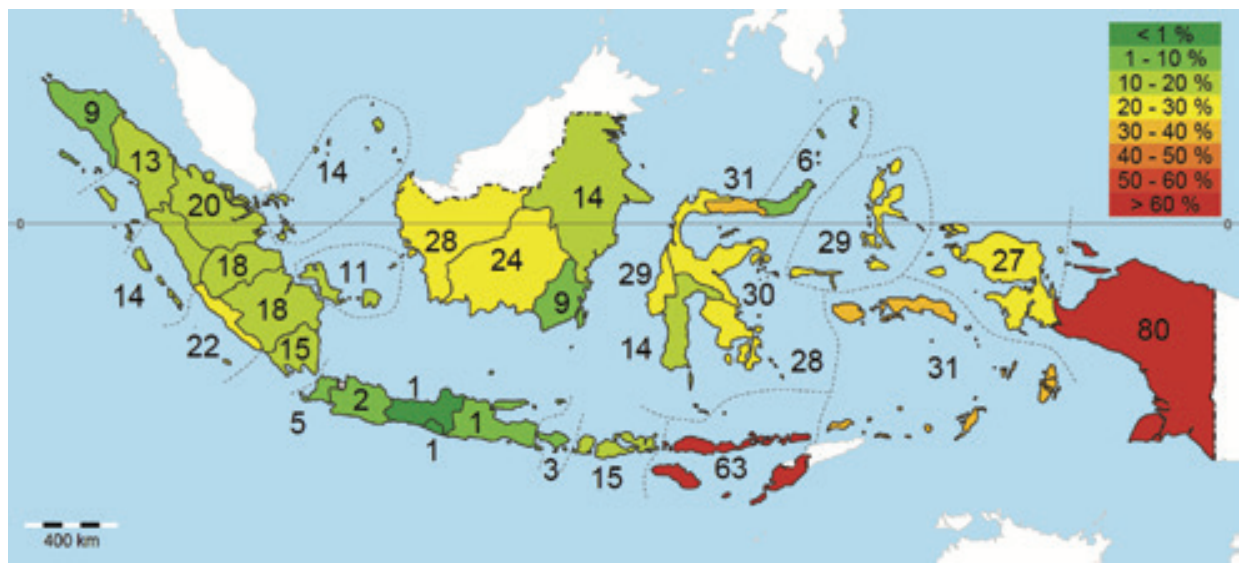

Fig. 4.2. The percentage of rural households lacking access to electricity per province in Indonesia. Based on data from 2010 from BPS [24].

As can be seen in Fig. 4.3, roughly a quarter of all rural households in Indonesia without electricity live in ENT and Papua. So, even in absolute numbers, most households lacking access to electricity live in these two provinces. Especially the province of ENT seems to be a promising location for off-grid PV systems, due to its large number of rural households without access to electricity combined with the high level of irradiation received in this part of Indonesia, as shown in Fig. 2.9. 


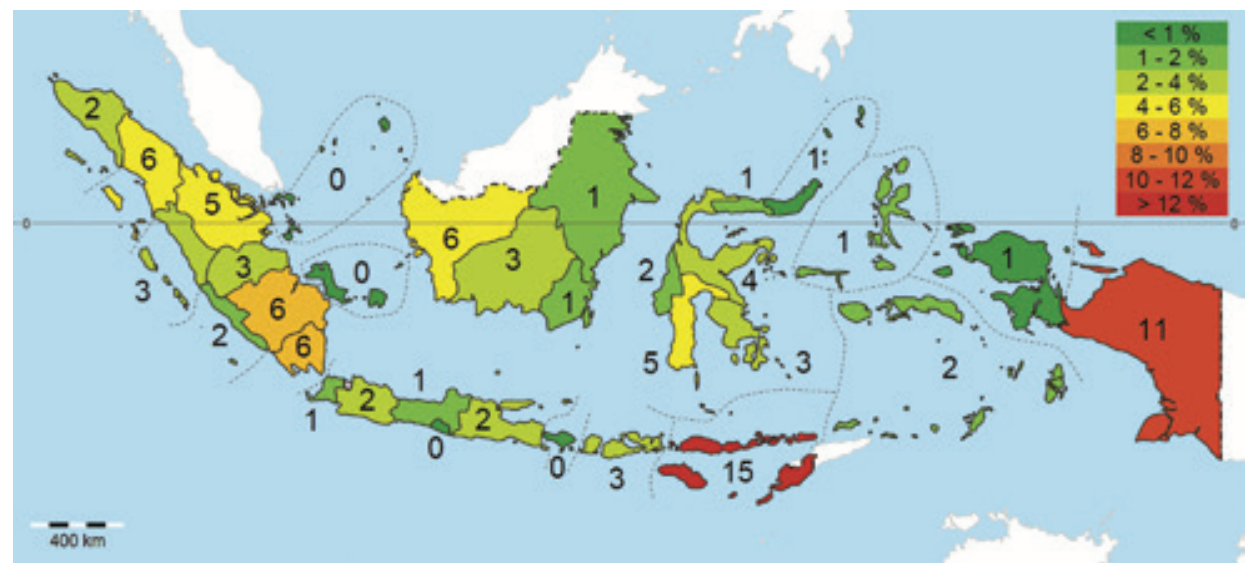

Fig. 4.3. The geographical distribution of non-electrified rural households per province in Indonesia as a percentage of the total of these households in Indonesia. Based on data from BPS [24].

Comparing Fig. 4.2 and Fig. 4.3 shows the influence of the population density as show in Fig. 2.1. Due to the high population density at Java, the significant lower relative values for Java compared with the other provinces as shown in Fig. 4.2, are less pronounced in the absolute values as shown in Fig. 4.3.

\subsubsection{Rural electricity demand}

It is hard to exactly determine the off-grid electricity demand in Indonesia, since no detailed data are available.

A study by Ruijven et al. [69] models the energy use of households in India, based on primary drivers (population, household expenditure, household size and temperature), intermediate indicators (floor space and electrification) and end-use functions (cooking, water heating, space heating, lighting and appliances). Besides, income distribution and rural/urban breakdown are taken into account. The final energy use is divided into fuel use and electricity. The model shows reasonable results for India, however it is questionable whether it is applicable in Indonesia. The different culture, fuel prices and availability and geography could influence the model's accuracy. Besides, for this study the focus is on the electricity demand only, assuming that the off-grid PV system supplies the electricity.

Figures about the average rural electricity consumption in developing countries found in literature vary between $240-768 \mathrm{kWh} /$ year per household [107, 108]. Based on these figures and on data from PLN [25] and BPS [24], it is assumed that a household living offgrid would consume between 250 - $450 \mathrm{kWh} /$ year.

Apart from the residential electricity consumption, there will be other end-uses in the commercial or public sector, like: local workshops, offices and schools. Their share would be relatively low in the agricultural areas which are not connected to the grid [73]. Although detailed data are lacking, based on rural employment data [24] and a study from Gibson and Olivia [109], it is estimated that this would not exceed 5\% of the connections, 
especially in areas lacking electricity. As such, they are included in this study as households with productive use, see Table 4-1.

For the potential of off-grid PV systems, not only the total electricity demand is of importance, the period of the day in which the electricity is consumed is another crucial influencing factor. Details of this electricity demand profile are lacking, however most households in rural areas use their electricity mainly for lighting and in a lesser extent for a fan and radio and TV [69, 107]. Obviously, the electricity required for lighting will largely take place between sunset and sunrise, especially during the time before sunrise from roughly 5 am -6 am and between sunset and bedtime, so roughly from $6 \mathrm{pm}-10 \mathrm{pm}$. In contrast, non-residential consumers will consume most of their electricity during daytime.

To be able to model the off-grid PV potential two categories are proposed (see Table 4-1), a similar methodology is applied by Ruijven et al. [73] and Blum et al. [36]. The high demand profile extends the low demand profile. It is assumed that the electricity for productive use is required during working days only.

TABle 4-1: Two CATEgORIES FOR EleCtricity DEMAND PER HOUSEHOLD

\begin{tabular}{lccc}
\hline Category & $\begin{array}{c}\mathrm{E}_{\mathrm{HH}, \mathrm{y}} \\
(\mathrm{kWh} / \text { year })\end{array}$ & $\begin{array}{l}\mathrm{P}_{\mathrm{L}, \max } \\
(\mathrm{kW})\end{array}$ & $\boldsymbol{\alpha}$ \\
\hline $\begin{array}{l}\text { Low } \\
\text { (mainly lighting, fan, TV \& radio) }\end{array}$ & 250 & 0.128 & 1.0 \\
\hline $\begin{array}{l}\text { High } \\
\text { (with productive use) }\end{array}$ & 500 & 0.138 & 0.6 \\
\hline
\end{tabular}

The off-grid PV potential can then be determined by:

$$
E_{p, P V, o g, y}=\alpha_{h} H H_{p, 4, h} E_{H H, y, h}+\alpha_{l} H H_{p, 4, l} E_{H H, y, l}
$$

where $E_{p, P V, o g, y}$ is the electricity ( $\mathrm{kWh} /$ year) generated by off-grid PV in province $p, \alpha(0 \leq \alpha$ $\leq 1$ ) determines the share of the electricity demand which is generated by $\mathrm{PV}, \mathrm{HH}_{p, 4}$ is the number of rural households in province $p$ without access to electricity, $E_{H H, y}$ is the yearly electricity demand of a household. The subscripts $h$ and $l$ indicate the high demand or low demand category, respectively.

Assumed is that the total rural electricity generation in a province is based on PV systems and diesel generators.

\subsubsection{Rural population distribution}

Now the electricity demand of a rural household is modeled, it is necessary to obtain information about the clustering of these households in order to determine the energy 
demand per area. Therefore the population density distribution of the rural population without access to electricity per province, $N_{p, 4}$, should be known.

Detailed data are not publicly available, estimates from SEDAC [110] give an indication of the population distribution in Indonesia on a country level, however a drawback of the estimations from SEDAC is the skewed population distribution in Indonesia, as can be seen Fig. 2.1. Therefore the national average is not representative for each of the provinces.

To be able to determine the rural electricity demand per area, the population density distribution will be modeled in this study.

Based on the assumption of average population densities $(\overline{N D})$ for the various areas made in the previous Chapter, the population density distribution can be approximated. The geographical population density distribution follows often an exponential trend, therefore this study proposes an exponential function for the modeling of this distribution. This is schematically shown in Fig. 4.4, in which the green area is equal to the provincial rural population without grid access. The average population densities $\overline{N D}_{1}, \overline{N D}_{2}$ and $\overline{N D}_{3}$, which are included in the figure, are based on the previous Chapter and represent the average population density in the urban cores, suburbs and electrified rural villages, respectively. The urbanization and electrification rate of the province, respectively $U R_{p}$ and $E R_{p}$, are illustrated in Fig. 4.4 as well.

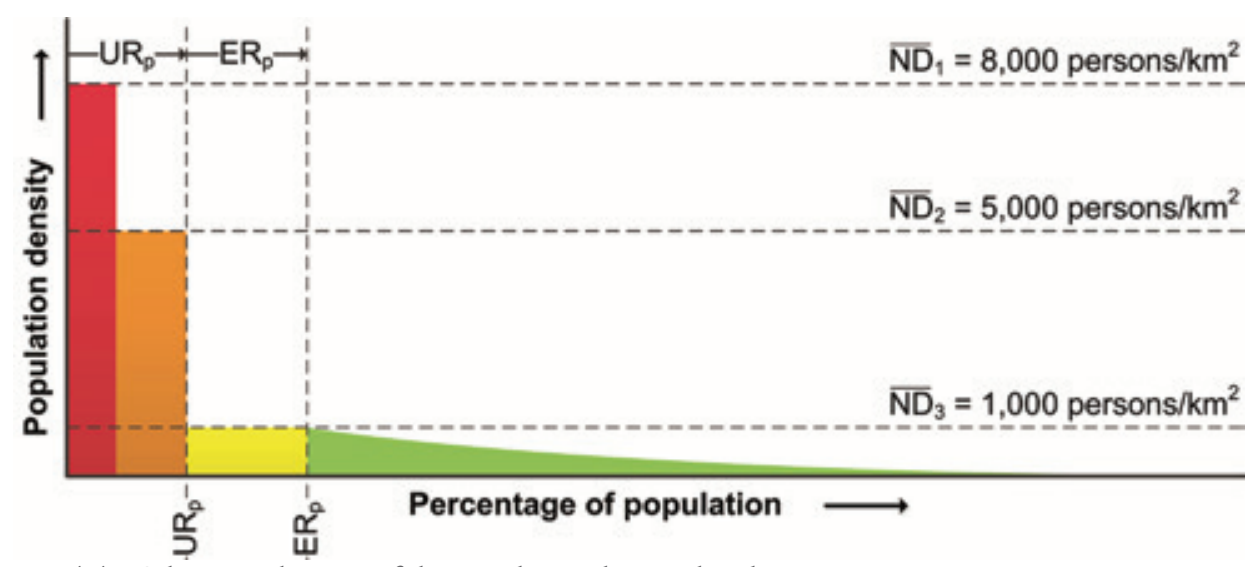

Fig. 4.4. Schematic diagram of the population density distribution.

To calculate the actual population densities per province, some additional boundary conditions have to be set. Although most rural people live inside small settlements, it is assumed that in each province there is at least one area in which the population density is very low. This has been modeled by the boundary condition which requires that the last bin of the population is equal to, or less than, 10 persons $/ \mathrm{km}^{2}$. Further is assumed that the highest population density in non-electrified rural areas is smaller than the average population density assumed for rural electrified villages, $\overline{N D}_{3}$, which equals 1,000 
persons $/ \mathrm{km}^{2}$. The rationale behind this is, that if the population density would be larger, it would most likely already have been connected to the (local) grid, because of the favorable conditions for infrastructure investments in these areas. Based on these aforementioned assumptions, the rate of decline, $\lambda_{N D, p}$, in population density over distance can be determined according to the flowchart shown in Fig. 4.5.

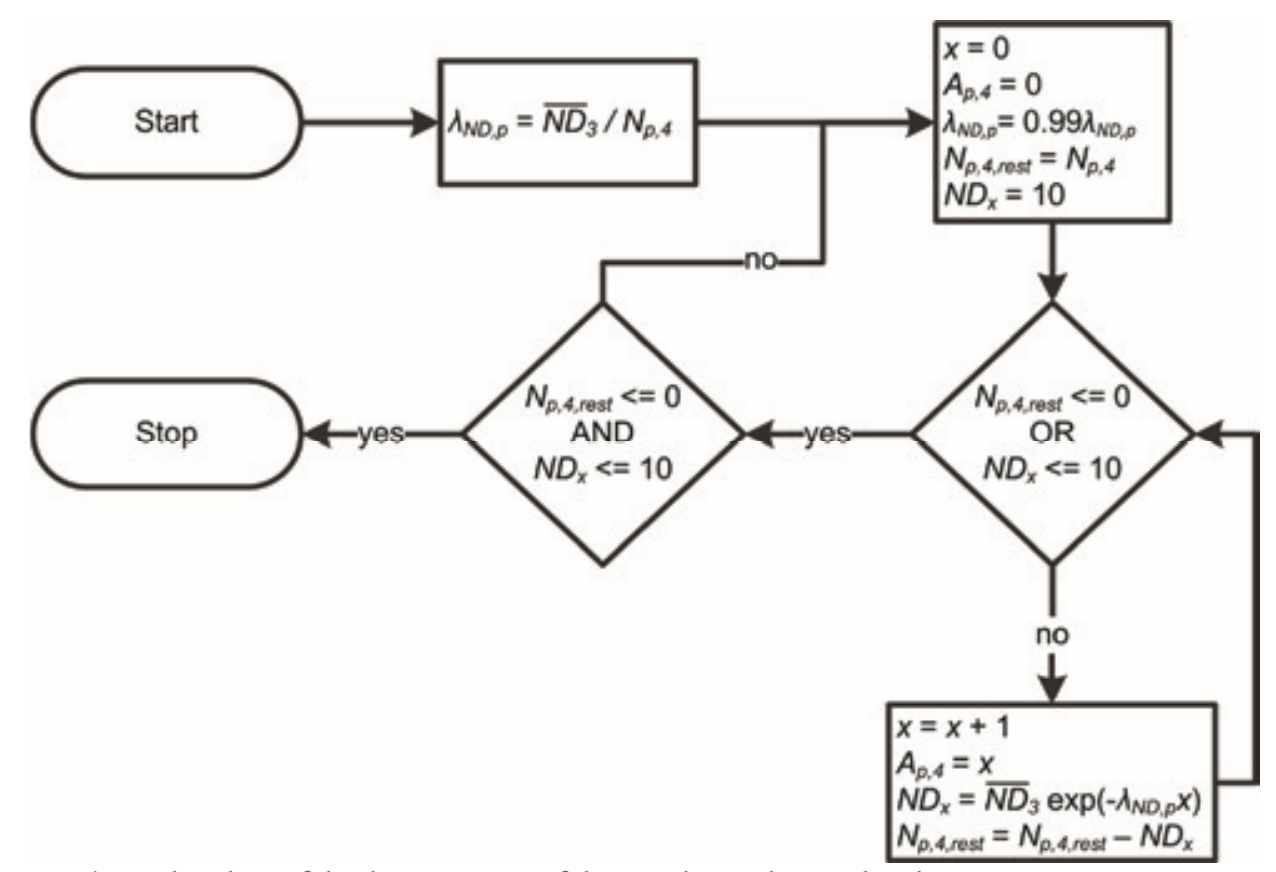

Fig. 4.5. Flowchart of the determination of the population density distribution per province.

Further is assumed that each step $x$ corresponds to a population density $N D_{x}$ inside an area equal to $1 \mathrm{~km}^{2}$, so that the population living in this area is numerically equivalent to the population density and $x$ is numerically identical to $A_{p, 4}$.

Now the population distribution has been modeled, the electricity demand per area can be determined.

\subsubsection{PV system configuration}

There are two PV system configurations evaluated in this study: hybrid local grid (lg) consisting of PV systems, batteries and diesel generators, and stand-alone (sa) PV systems with batteries.

When a local grid is viable, it is assumed to be the most preferred option. According to a rule of thumb for the feasibility of isolated grids from SWECO [111], the number of connections $c$ in an area within a radius $r$ of $500 \mathrm{~m}$ should be at least 100 . Most of the electricity consumers in rural areas are residential, therefore has been assumed that the 
connections are equal to the number of households. Then the minimum population density in a province for a local grid in persons $/ \mathrm{km}^{2}, N D_{p, l g, m i n}$, can be determined as follows:

$$
N D_{p, l g, \min }=\frac{c}{10^{-6} \pi r^{2}} \times \bar{N}_{p, 3,4, H H}
$$

where $\bar{N}_{p, 3,4, H H}$ is the average household size in rural areas of province $p$.

With an average household size of about 4 persons in rural areas in Indonesia, the average minimum population density for a local grid in Indonesia is 506 persons $/ \mathrm{km}^{2}$.

The population living in areas with a population density larger than $N D_{p, l g, m i n}$ is assumed to be served with a local grid. This area, $A_{p, l g, N D}$, is determined by:

$$
A_{p, l g, N D}=\frac{-1}{\lambda_{N D, p}} \ln \left(\frac{N D_{p, \min }}{\overline{N D}_{3}}\right)
$$

Next, the population living in this area, $N_{p, l g, N D}$, is obtained:

$$
N_{p, l g, N D}=\sum_{x=1}^{A_{p, l g, N D}} N D_{x}
$$

where

$$
N D_{x}=\overline{N D}_{3} \exp \left(-\lambda_{N D, p} x\right)
$$

Besides, if the population density is less than $N D_{p, l g, m i n}$, different factors, e.g. the load size and willingness to pay, determine whether a local grid is viable or not [111]. The minimum load $P_{L}$ should be roughly $10 \mathrm{~kW}$ to meet the criteria for a local grid [111]. It is assumed that when this criterion has been met, in $30 \%$ of these cases a local grid is viable.

Furthermore, it is assumed that when a local grid is viable, the settlement's electricity demand falls into the category of high demand, otherwise the settlement is categorized as low. The part of the rural population served by a local grid based on the minimal load requirement, $N_{p, l g, L}$, is therefore:

$$
N_{p, l g, L}=0.3 \times \sum_{i=A_{p, l g, N D}}^{A_{p, 4}}\left\{N D_{i} \mid \frac{N D_{i}}{\bar{N}_{p, 3,4, H H}} P_{L, \max , h}>10\right\}
$$


The total population served by a local grid is therefore:

$$
N_{p, l g}=N_{p, l g, N D}+N_{p, l g, L}
$$

Subsequently, the population served by stand-alone PV systems, $N_{p, s a}$, will be:

$$
N_{p, s a}=N_{p, 4}-N_{p, l g}
$$

where $N_{p, 4}$ is the total rural population in province $p$ with no electricity access.

\subsubsection{PV system sizing}

System sizing is based on the assumed electricity demand scenarios (Table I) and the available irradiation (Fig. 2.9) based on data from the $\mathrm{NASA}^{8}[64]$ which has been averaged over each $1 \times 1^{\circ}$ latitude/longitude grid cell inside the bounding box area of each province obtained by [35].

The following formulas related to the system sizing are presented for the system configuration in a local grid, lg. If not explicitly mentioned, the same formulas can be applied for the stand-alone configuration, $s a$, by replacing the subscripts $l g$ and $h$ by $s a$ and $l$, respectively.

The daily electricity delivered by the PV system for a household, $E_{P V, l g, H H, d}(\mathrm{kWh} / \mathrm{d})$, is determined as follows:

$$
E_{P V, l g, H H, d}=\frac{\alpha_{h} E_{H H, y, h}}{365 P R_{l g}}
$$

where $P R_{a}$ is the performance ratio of the PV system in configuration $a$.

The nominal capacity of the PV modules for a household in province $p, C_{P V, p, l g, H H}\left(\mathrm{~kW}_{\mathrm{p}}\right)$, is determined as follows:

$$
C_{P V, p, l g, H H}=\frac{E_{P V, l g, H H, d}}{\bar{H}_{p, d}}
$$

where $\bar{H}_{p, d}$ is the daily average horizontal irradiation $\left(\mathrm{kWh} / \mathrm{m}^{2} / \mathrm{d}\right)$ in province $p$, which is numerically identical to the peak sun hours? ${ }^{9}$. It is assumed that the yearly difference in horizontal vs. tilted irradiation in Indonesia is negligible, due to the location close to the equator.

\footnotetext{
${ }^{8}$ Data based on monthly averaged values per latitude/longitude grid cell for a 22-year period (July 1983 - June 2005).

${ }^{9}$ A peak sun hour is defined as $1 \mathrm{~kW} / \mathrm{m}^{2}$
} 
The inverter capacity for a household in province $p, C_{i n v, p, l g, H H}(\mathrm{~kW})$, is chosen to be $C F_{\text {inv }}$ times the total peak power of the PV modules if this is larger than the peak load, otherwise the inverter capacity is chosen to be equal to the peak load:

$$
C_{\text {inv }, p, l g, H H}=\left\{\begin{aligned}
C F_{\text {inv }} P_{P V, p, l g, H H}, & C F_{i n v} C_{P V, p, l g, H H}>P_{L, \max , h} \\
P_{L, \max , h}, & C F_{i n v} C_{P V, p, l g, H H} \leq P_{L, \max , h}
\end{aligned}\right.
$$

The battery capacity for a household $C_{b a t t, l g, H H}(\mathrm{kWh})$ is determined as follows:

$$
C_{\text {batt }, l g, H H}=\frac{E_{P V, l g, H H, d} \operatorname{doa}_{l g}}{\eta_{\text {wires }} \eta_{c t r l} \eta_{\text {batt }} D O D}
$$

where $\mathrm{doa}_{l g}$ is the number of days of autonomy, $\eta_{\text {wires }}, \eta_{c t r l}$ and $\eta_{\text {batt }}$ are the efficiencies of the wires, charge controller and battery charge, respectively, and $D O D$ is the battery's depth of discharge.

TABLE 4-2: ASSUMPTIONS FOR ENERGY SYSTEM SIZING

\begin{tabular}{llcc}
\hline Variable $^{*}$ & Symbol & Value & Unit \\
\hline Diesel generator efficiency, local grid & $\eta_{D G, l g}$ & 30 & $\%$ \\
\hline Diesel generator efficiency, local grid reference & $\eta_{D G, \text { lg,ref }}$ & 25 & $\%$ \\
\hline Diesel generator efficiency, stand-alone reference & $\eta_{D G, s a, r e f}$ & 20 & $\%$ \\
\hline Diesel generator best efficiency point & $D G_{B E P}$ & 80 & $\%$ \\
\hline Wires efficiency & $\eta_{\text {wires }}$ & 97 & $\%$ \\
\hline Battery charge controller efficiency & $\eta_{c t r l}$ & 98 & $\%$ \\
\hline Inverter efficiency & $\eta_{\text {inv }}$ & 95 & $\%$ \\
\hline Inverter capacity factor & $C F_{\text {inv }}$ & 0.83 & - \\
\hline Battery (dis)charge efficiency & $\eta_{\text {batt }}$ & 85 & $\%$ \\
\hline Depth of discharge & $D O D$ & 50 & $\%$ \\
\hline Autonomy, local grid & doalg & 60 & $\%$ \\
\hline Autonomy, stand-alone & doa sa & 200 & $\%$ \\
\hline
\end{tabular}

The subscript ref indicates the efficiency used in the reference scenario in which only diesel generators are used to supply electricity.

In the hybrid configuration, the diesel genset will mainly produce the electricity during the peak hours in the evening. In this case, the genset can be sized to run at an efficient level during these peak hours, the moments of lower power demand during the day and night will be covered by the PV-battery system. 
The nominal power of the diesel genset for a household, $P_{D G, H H}(\mathrm{~kW})$, is determined as follows:

$$
P_{D G, H H}=\frac{P_{L, \max , h}}{D G_{B E P}}
$$

where $D G_{B E P}$ is the best efficiency point (BEP) of the diesel genset.

To size the PV systems, batteries and diesel generators, a number of assumptions have been made, see Table 4-2.

The battery self-discharge is assumed to be negligible due to the short term storage. For standalone PV systems the performance ratio, $P R_{s a}$, is assumed to be $55 \%$, due to (i) mismatch between time of electricity use and production, (ii) shadow losses and (iii) due to higher PV module temperatures in these tropical areas [77]. For PV systems in an isolated grid a performance ratio, $P R_{l g}$, of $70 \%$ is assumed.

\subsubsection{Costs}

To compare the costs of the different configurations the levelized cost of electricity (LCOE) is used, which is calculated as follows:

$$
L C O E_{p}=\frac{C A P E X_{P V, p}+\sum_{n=1}^{L T} \frac{A O_{p}}{(1+D R)^{n}}-\frac{R V_{p}}{(1+D R)^{n}}}{\sum_{n=1}^{N} \frac{E_{P V, p, l g} \times(1-S D R)^{n}+E_{d s l, p}}{(1+D R)^{n}}}
$$

where $L C O E_{p}$ is the total $\mathrm{LCOE}$ in province $p, C A P E X_{P V}$ is the initial investment for the $\mathrm{PV}$ system, $A O$ is the annual costs, $R V$ is the residual value, $D R$ is the discount rate, $E_{P V}$ is the annual electricity production by $\mathrm{PV}, S D R$ is the system degradation rate, $E_{d s l}$ is the electricity production by diesel gensets and $L T$ is the project's lifetime in years.

The costs of the PV system are included in the initial investment $C A P E X_{P V}$, the costs of the other components (e.g. batteries, inverters, fuel) are included in the annual costs $A O$ which include maintenance and replacement costs as well. To determine the LCOE a number of cost assumptions have been made, see Table 4-3.

The cost of diesel is based on the fuel costs from PLN per province from 2010 [25] and adjusted for price increase ${ }^{10}$ and exchange rate ${ }^{11}$, resulting in an average cost of diesel in Indonesia of $0.91 \$ / 1$. The fuel costs from PLN include transportation costs already, however these costs represent only the average fuel costs in the areas in which PLN operates. Since these are mainly urban areas, the fuel costs for rural areas would be larger, therefore extra costs are taken into account for the transportation of fuel, as shown in Table

\footnotetext{
${ }^{10}$ The average diesel price over 2010 has increased with a factor 1.70 compared with the price in April 2014, source: www.indexmundi.com.

${ }^{11}$ The exchange rate of 11,546 IDR/USD as of 30-4-2014 is used in this study, source: www.xe.com.
} 
4-3. For the hybrid system configuration, the influence of transportation costs is assumed to be small, since a local grid is only viable in more populated areas. In contrast, for the stand-alone PV system configuration, the influence is assumed to be higher, since these offgrid systems are mainly located in sparsely populated remote areas. The additional transportation costs are modeled quite modest; in the study of Blum et al. [36], factors of 2.0 and 2.73 have been applied for the medium and high cost scenario, respectively.

TABLE 4-3: ASSUMPTIONS FOR THE CALCULATION OF THE LCOE

\begin{tabular}{|c|c|c|}
\hline Variable & Value & Unit \\
\hline \multicolumn{3}{|l|}{ Investment costs } \\
\hline $\begin{array}{l}\text { PV system (PV modules, mounting \& installation) } \\
\left(C A P E X_{P V, C}\right)\end{array}$ & 2,500 & $\$ / \mathrm{kW}_{\mathrm{p}}$ \\
\hline Inverter & 500 & $\$ / \mathrm{kW}$ \\
\hline Battery cost & 150 & $\$ / \mathrm{kWh}$ \\
\hline Diesel generator & 650 & $\$ / \mathrm{kW}$ \\
\hline \multicolumn{3}{|l|}{ O\& $M$ costs } \\
\hline Annual operations $\mathrm{PV}\left(A O_{C}\right)$ & 13 & $\$ / \mathrm{kW}_{\mathrm{p}}$ \\
\hline Fixed O\&M costs diesel & 15 & $\$ / \mathrm{kW} /$ year \\
\hline Variable O\&M costs diesel & 0.03 & $\$ / \mathrm{kWh}$ \\
\hline \multicolumn{3}{|l|}{ Fuel } \\
\hline Energy density diesel & 35.86 & $\mathrm{MJ} / \mathrm{l}$ \\
\hline Additional transport costs (local grid) & 10 & $\%$ \\
\hline Additional transport costs (stand-alone) & 50 & $\%$ \\
\hline \multicolumn{3}{|l|}{$\begin{array}{ll}\text { Lifetime } \\
\end{array}$} \\
\hline Diesel & 20 & years \\
\hline $\mathrm{PV}(L T)$ & 25 & years \\
\hline Inverter & 12 & years \\
\hline Battery & 5 & years \\
\hline \multicolumn{3}{|l|}{$L C O E$} \\
\hline Residual value $(R V R)$ & 0.5 & $\begin{array}{c}\% \text { of } \\
C A P E X_{P V, p}\end{array}$ \\
\hline Discount rate $(D R)$ & 5.75 & $\%$ \\
\hline System degradation rate $(S D R)$ & 0.5 & $\%$ \\
\hline
\end{tabular}




\subsection{Off-grid PV potential and costs}

In Fig. 4.6 the differences in LCOE for PV system configuration $a$ compared with the LCOE based on diesel gensets only are shown for each province. Also, the potential electricity generation by PV is included. The total annual electricity which can be produced with hybrid PV systems in Indonesia is $943 \mathrm{GWh}$, of which $566 \mathrm{GWh}$ is generated by PV and the other 377 GWh by diesel generators. This amount can be produced by a total capacity of 427 MW PV systems, $321 \mathrm{MW}$ diesel gensets and 2.5 GWh battery capacities. The total cost over the complete lifetime of 25 years is estimated to be USD 7.4 billion $^{12}$, which includes among others fuel and replacements, but excludes expected increasing fuel prices and decreasing PV system prices. This results in an average LCOE of $0.38 \$ / \mathrm{kWh}$, which is lower than the average LCOE of $0.47 \$ / \mathrm{kWh}$ for the reference scenario based on diesel gensets only.

As can be seen, for all provinces in Indonesia the LCOE of hybrid PV systems is lower than that of conventional electricity production by diesel gensets. Only in the province of West-Papua hybrid PV is less attractive, mainly due to lower cost of diesel in this province according to data from PLN [25].

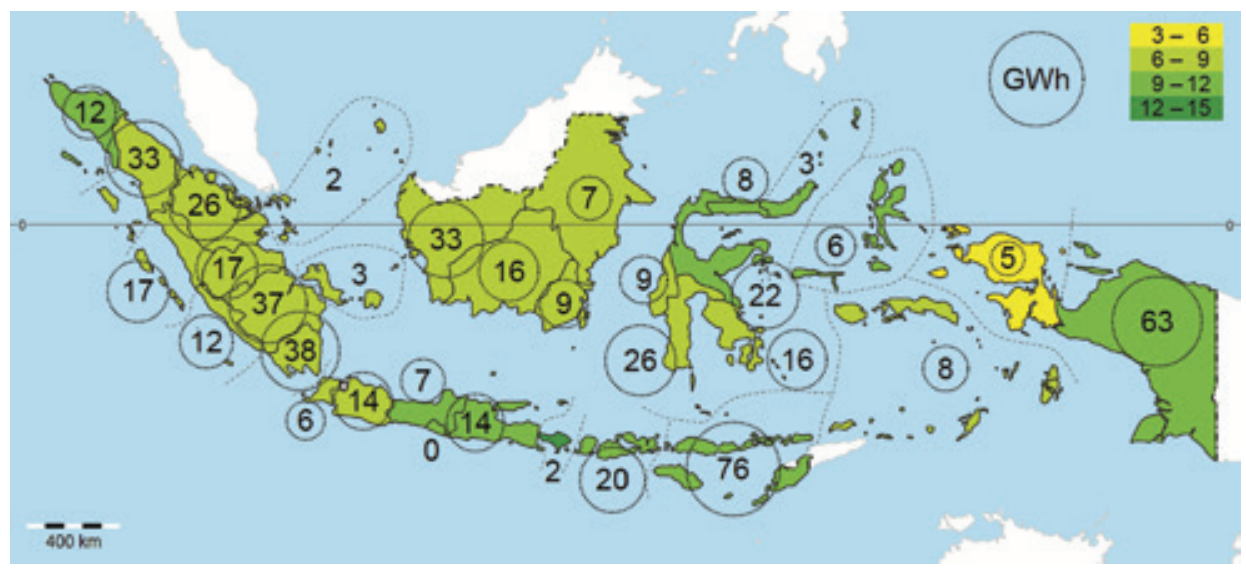

Fig. 4.6. The difference in LCOE between 100\% diesel based electricity and hybrid PV system configuration. The colors indicate the difference in costs in $\$ / \mathrm{kWh}$, positive values show a lower LCOE for the PV-battery-diesel option. The circles indicate the potential amount of PV in GWh/year.

In Fig. 4.7 the differences in LCOE for stand-alone PV system configuration compared with the LCOE based on diesel gensets only are shown for each province. The total electricity that can be produced with PV-battery-systems in Indonesia is $403 \mathrm{GWh}$ per year, of which 339 GWh per year is cost-effective. The total amount can be produced by a

\footnotetext{
${ }^{12}$ Based on the LCOE calculation, which includes a discount rate and residual value, the total cost is estimated to be USD 4.6 billion.
} 
total of $389 \mathrm{MW}_{\mathrm{p}}$ of PV and 6.0 GWh battery capacities. The total cost for these standalone PV systems over the complete lifetime of 25 years is USD 5.9 billion $^{13}$, resulting in an average LCOE of $0.76 \$ / \mathrm{kWh}$.

As can be seen, in most provinces in Indonesia the stand-alone PV system is a cheaper solution compared with the LCOE of electricity generation by diesel. In some provinces, namely South and East Kalimantan, Maluku, West Sulawesi, Lampung, Jambi and West Papua it is not cost-effective yet, although the LCOE of diesel is only significant lower (> $0.01 \$ / \mathrm{kWh})$ in the provinces Maluku $(0.01 \$ / \mathrm{kWh})$ and West-Papua $(0.09 \mathrm{kWh})$. Besides, in some other provinces, namely Banten, West and Central Kalimantan, North and South Sumatra, Bangka-Belitung, Bengkulu and Riau, the difference in LCOE is relative low compared with the diesel-only scenario $(<0.01 \$ / \mathrm{kWh})$.

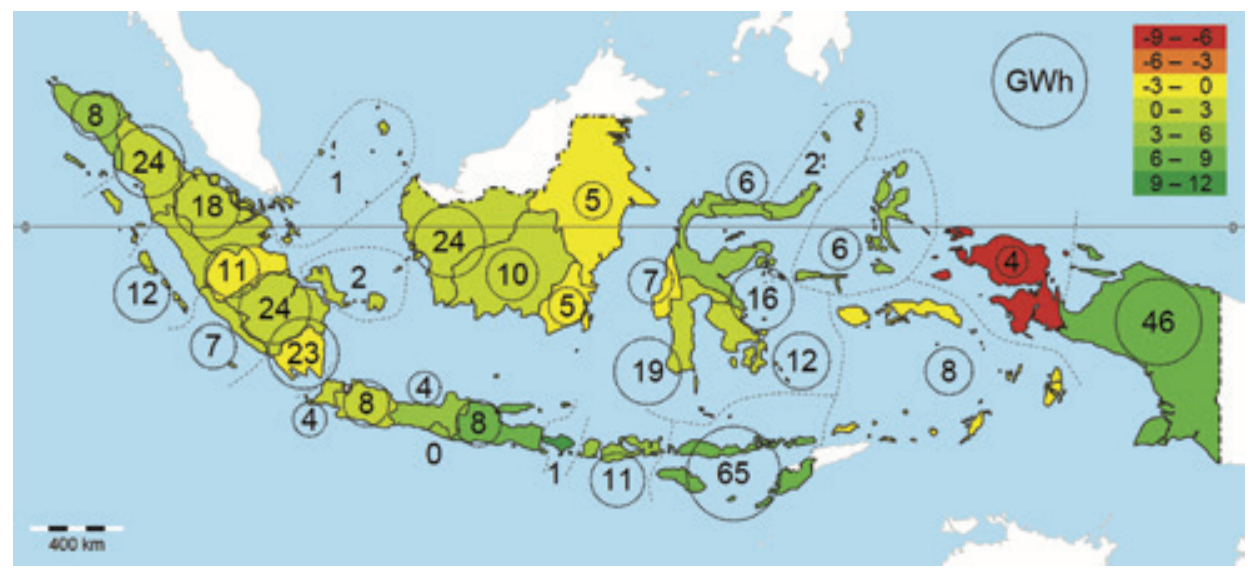

Fig. 4.7. The difference in LCOE between $100 \%$ diesel based electricity and stand-alone PV system configuration $b$. The colors indicate the difference in costs in $\$ / \mathrm{kWh}$, positive values show a lower LCOE for the stand-alone PV system. The circles indicate the potential amount of PV in GWh/year.

The LCOEs found in this study are compared with those found in the study of Blum et al. [36]. Since they distinguished between subsidized Indonesian and world fuel prices, the LCOEs based on the unsubsidized world fuel prices have been compared, because the real cost of electricity has been evaluated in this study.

The LCOE of both configurations are in line with the calculated LCOE in the study of Blum et al., however the average LCOE of the stand-alone PV option in this study is slightly higher. Besides, the average LCOE of the hybrid PV system found in this study corresponds to the lower range of LCOE for the hybrid solar PV/battery/diesel system. The LCOE of electricity generated by diesel in the hybrid reference scenario corresponds to the lower range of LCOE for diesel found by Blum et al. Although a larger range in additional

\footnotetext{
${ }^{13}$ Based on the LCOE calculation, which includes a discount rate and residual value, the total cost is estimated to be USD 3.8 billion.
} 
transportation costs is assumed in the study of Blum et al., the LCOE of the stand-alone reference scenario in this study matches with the higher range of LCOE. This can be explained by the higher cost of fuel applied in this study, which is $0.91 \$ / 1$ on average, compared with the approximated $0.77 \$ / \mathrm{kWh}^{14}$ applied by Blum et al., based on values from 2012.

From Fig. 4.6 and Fig. 4.7 it can be concluded that in particular the provinces with the largest population without electricity - Papua and ENT - show one of the largest differences in LCOE for both system configurations.

\subsubsection{Sensitivity analysis}

Since it is difficult to validate the results, a sensitivity analysis can give insight in the importance of the model parameters and can as such determine which parameters require additional research in order to reduce the uncertainty of the model output.

An initial one-at-a-time sensitivity analysis was carried out to indicate the most sensitive model parameters. This analysis showed that the following parameters are important: PV module lifetime, PV system investment costs, battery's depth of discharge, battery's days of autonomy, battery lifetime, performance ratio, battery investment costs, the fuel cost and the discount rate.

The energy demand itself has minor influence on the LCOE of stand-alone PV. For the hybrid configuration a decrease of energy demand by $50 \%$, increased the average LCOE with $9 \%$, where an increase of $50 \%$ in energy demand caused the LCOE to decrease by $2 \%$ only.

The input values for the sensitivity analysis are relative to the values applied in this study as shown in Table 4-2 and Table 4-3 and are assumed to represent a realistic range of values for the particular parameters in Indonesia. These variations are shown as percentages in Table 4-4 and Table 4-5.

In Table 4-4 the results of the sensitivity analysis are shown for the hybrid PV system configuration. The average LCOE for all provinces in Indonesia is in the range of $0.34-$ $0.67 \$ / \mathrm{kWh}$.

Changes in the fuel cost will affect the reference scenario as well. For the normal reference scenario (diesel only), the average LCOE is $0.47 \$ / \mathrm{kWh}$. If the fuel cost is increased with 50\%,100\% and 200\%, this average LCOE will become 0.68, 0.89 and 1.30 $\$ / \mathrm{kWh}$, respectively. Since the additional transportation costs are modeled as an increase in the fuel costs, the LCOE values for an increase in fuel cost apply to an equal increase in these transportation costs as well.

\footnotetext{
${ }^{14} 0.61 € /$ litre in 2012
} 
TABle 4-4: Results Sensitivity ANAlysis LCOE Hybrid PV SySTEM CONFIGURATION

\begin{tabular}{lrrrr}
\hline Uncertain system parameters & Low & Moderate & High & Very high \\
\hline \multirow{2}{*}{ PV module lifetime } & $(50 \%)$ & $(80 \%)$ & $(100 \%)$ & $(120 \%)$ \\
& 0.424 & 0.391 & 0.381 & 0.376 \\
\hline \multirow{2}{*}{ PV system investment costs } & $(50 \%)$ & $(80 \%)$ & $(100 \%)$ & $(150 \%)$ \\
& 0.340 & 0.365 & 0.381 & 0.423 \\
\hline \multirow{2}{*}{ Performance ratio (PR) } & $(60 \%)$ & $(90 \%)$ & $(100 \%)$ & $(120 \%)$ \\
& 0.456 & 0.394 & 0.381 & 0.363 \\
\hline \multirow{2}{*}{ Depth of discharge (DOD) } & $(50 \%)$ & $(80 \%)$ & $(100 \%)$ & $(150 \%)$ \\
& 0.473 & 0.404 & 0.381 & 0.351 \\
\hline \multirow{2}{*}{ Battery days of autonomy } & $(100 \%)$ & $(150 \%)$ & $(200 \%)$ & $(300 \%)$ \\
& 0.381 & 0.427 & 0.473 & 0.565 \\
\hline \multirow{2}{*}{ Battery lifetime } & $(40 \%)$ & $(60 \%)$ & $(80 \%)$ & $(100 \%)$ \\
& 0.501 & 0.434 & 0.401 & 0.381 \\
\hline \multirow{2}{*}{ Battery investment costs } & $(50 \%)$ & $(80 \%)$ & $(100 \%)$ & $(150 \%)$ \\
\multirow{2}{*}{ Fuel cost } & 0.336 & 0.363 & 0.381 & 0.427 \\
\hline \multirow{2}{*}{ Discount rate } & $(100 \%)$ & $(150 \%)$ & $(200 \%)$ & $(300 \%)$ \\
& 0.381 & 0.453 & 0.525 & 0.668 \\
\hline
\end{tabular}

Values in $\$ / \mathrm{kWh}$. The base case corresponds to an average LCOE of $0.381 \$ / \mathrm{kWh}$.

TABLE 4-5: RESUlts SENSITIVITY ANALYSIS LCOE STAND-ALONE PV SYSTEM CONFIGURATION

\begin{tabular}{lrrrr}
\hline Uncertain system parameters & Low & Moderate & High & Very high \\
\hline \multirow{2}{*}{ PV module lifetime } & $(50 \%)$ & $(80 \%)$ & $(100 \%)$ & $(120 \%)$ \\
& 0.860 & 0.779 & 0.763 & 0.753 \\
\hline \multirow{2}{*}{ PV system investment costs } & $(50 \%)$ & $(80 \%)$ & $(100 \%)$ & $(150 \%)$ \\
& 0.671 & 0.726 & 0.763 & 0.854 \\
\hline \multirow{2}{*}{ Performance ratio (PR) } & $(60 \%)$ & $(90 \%)$ & $(100 \%)$ & $(120 \%)$ \\
& 0.923 & 0.789 & 0.763 & 0.723 \\
\hline \multirow{2}{*}{ Depth of discharge (DOD) } & $(50 \%)$ & $(80 \%)$ & $(100 \%)$ & $(150 \%)$ \\
& 1.282 & 0.893 & 0.763 & 0.589 \\
\hline \multirow{2}{*}{ Battery days of autonomy } & $(100 \%)$ & $(150 \%)$ & $(200 \%)$ & $(300 \%)$ \\
\multirow{2}{*}{ Battery lifetime } & 0.763 & 1.022 & 1.282 & 1.802 \\
\hline \multirow{2}{*}{ Battery investment costs } & $(40 \%)$ & $(60 \%)$ & $(80 \%)$ & $(100 \%)$ \\
& 1.440 & 1.063 & 0.874 & 0.763 \\
\hline \multirow{2}{*}{ Discount rate } & $(50 \%)$ & $(80 \%)$ & $(100 \%)$ & $(150 \%)$ \\
& 0.503 & 0.659 & 0.763 & 1.022 \\
\hline
\end{tabular}

Values in $\$ / \mathrm{kWh}$. The base case corresponds to an average LCOE of $0.763 \$ / \mathrm{kWh}$. 
In Table 4-5 the average LCOE for all provinces of Indonesia based on the sensitivity analysis are shown for the stand-alone PV system configuration. The results show a LCOE in the range of $0.50-1.80 \$ / \mathrm{kWh}$.

Changes in the fuel cost will affect the reference scenario only. For the normal reference scenario (diesel only), the average LCOE is $0.78 \$ / \mathrm{kWh}$. If the fuel cost is increased with $50 \%, 100 \%$ and $200 \%$, this average LCOE will become $1.14,1.49$ and $2.21 \$ / \mathrm{kWh}$, respectively.

In Fig. 4.8 box charts show the range of possible LCOEs for the different system configurations and reference scenarios for all provinces, based on the values for the various input parameters. As can be seen, the LCOE of the hybrid PV system are within the range of 0.31 to $0.70 \$ / \mathrm{kWh}$. The stand-alone PV system shows a larger range of LCOE, with a range of 0.46 to $1.83 \$ / \mathrm{kWh}$. This difference can be mainly explained by the model's sensitivity to the battery related parameters, which is more pronounced in the stand-alone PV system.

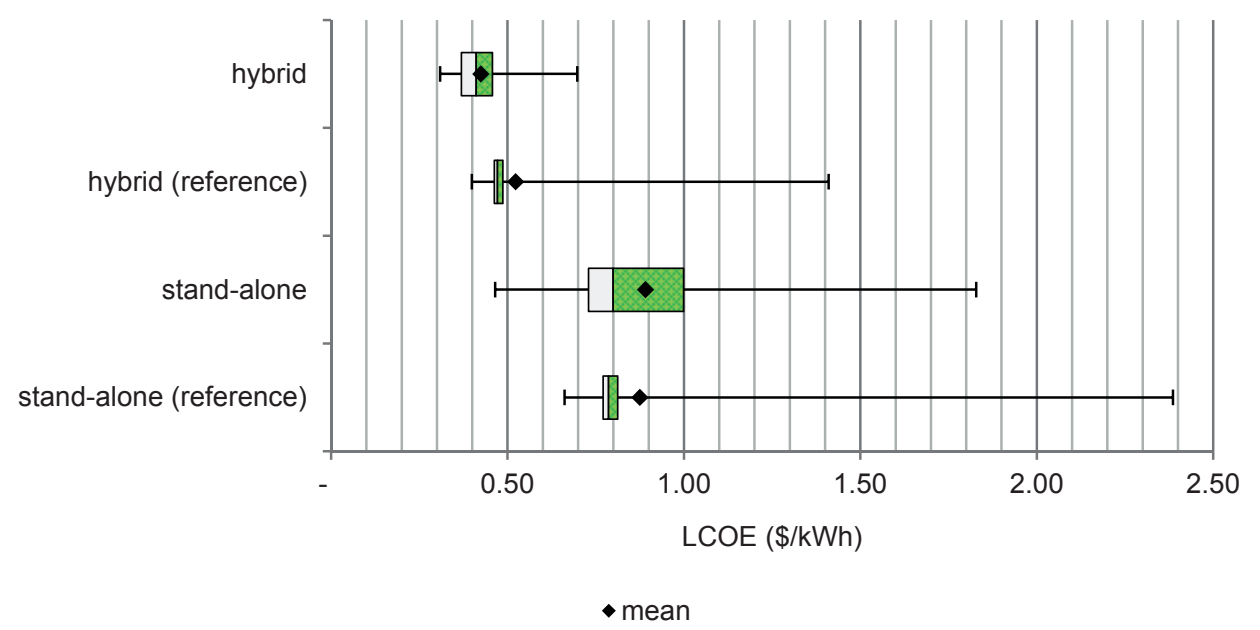

Fig. 4.8. Box chart of the overall results of the sensitivity analysis showing the range of possible LCOEs for the different scenarios for all provinces.

The boxplots of the reference scenarios are relatively small, because most model parameters do not influence the LCOE of the reference models; the LCOE of the reference model is mainly influenced by the cost of fuel. However, the large range of LCOE for these reference scenarios indicates that the LCOE is highly sensitive to the cost of fuel. 


\subsection{Comparison with existing off-grid PV projects}

Validation of the model is difficult. Since companies do not give details about the real costs of their PV installations, the costs are hard to validate. Besides, monitoring data of stand-alone PV systems in combination with load patterns are not available, making validation related to system sizing difficult. However analysis of data related to existing PV projects in Indonesia will give an indication about the accuracy of the model. Based on project data from two Indonesian off-grid PV system installers, the modeled system sizes and costs will be compared.

First the available data will be described, subsequently the project data will be analyzed. Based on these values the developed model will be validated on system sizing. Finally the costs of the projects will be compared with the modeled values.

\subsubsection{Data}

Data from two Indonesian PV system installers are available: Surya Energi Indonesia and TMLEnergy. Data from SuryaEnergi contain information about the sizing of stand-alone PV-battery systems for 19 projects, consisting of 62 PV systems in total. It includes the nominal installed PV capacity, the battery capacity and the number of households served per PV system. Furthermore, they supplied information about some design parameters. The expected lifetime of a PV panel is assumed to be 20 years, for an inverter and the batteries a lifetime of 3 years is assumed. The battery capacity is based on two days of autonomy and a DOD of $80 \%$.

Data from TMLEnergy comprises data from also 19 projects, consisting of $66 \mathrm{PV}$ systems including two grid-connected PV systems. The data includes nominal installed PV capacity, battery capacity, number of households served and the contract value. Unfortunately, but understandable, the real costs could not be obtained. From two PV systems data about battery size and the number households serves lacks, so in total data from 62 off-grid PV-battery systems from TMLEnergy can be used.

\subsubsection{Approach}

The box plot in Fig. 4.9 shows the variation for some ratios related to PV system design for the 124 off-grid PV-battery systems of which the data are available. In the same figure these ratios are compared with the values applied in this study for the 32 provinces.

As can be seen from Fig. 4.9, the data from the PV projects show large variations. In general, installation companies have a number of typical battery-PV system sizes, because they are bounded to the available sizes of the various system components. Besides, standardization of components simplifies processes such as procurement, installation, maintenance and product replacements which decreases the associated costs. Therefore, most installed PV systems will not represent an optimal system size in terms of electricity demand and supply. 


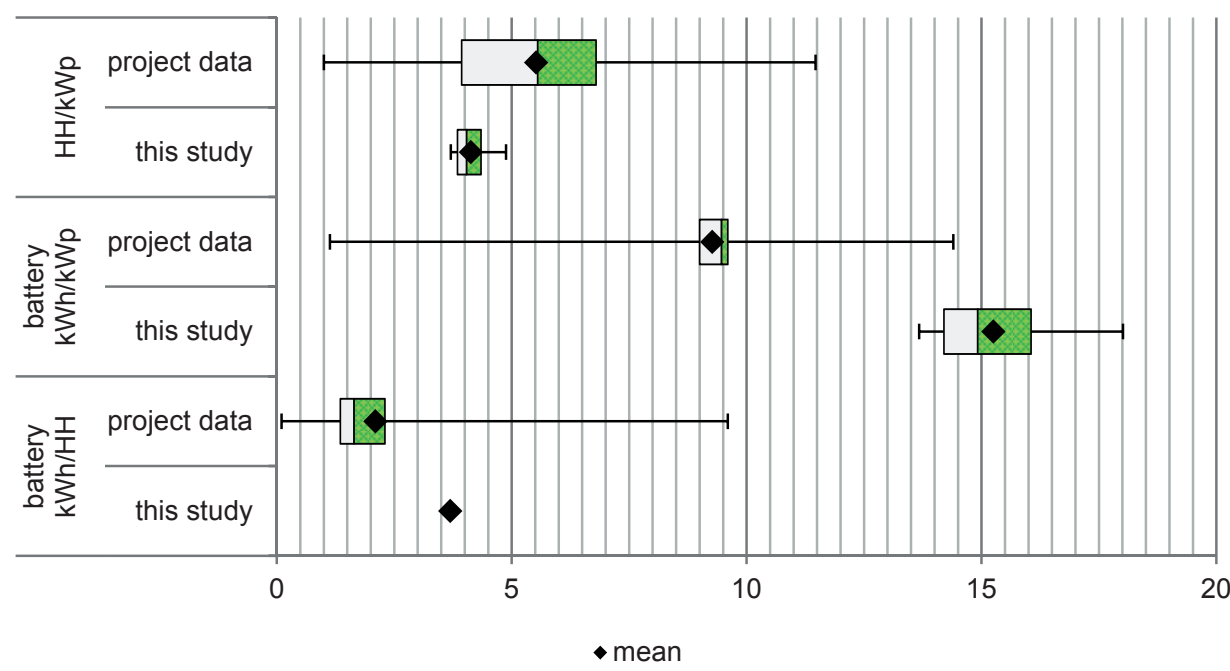

Fig. 4.9. Box plot of various ratios based on the $124 \mathrm{PV}$ systems from both installers compared with the values applied in this study based on the 32 provinces evaluated.

One such typical system size comprises a PV system of $15 \mathrm{~kW}_{\mathrm{p}}$ nominal installed capacity with a battery size of $144 \mathrm{kWh}$, which has a battery-PV ratio of $9.6 \mathrm{kWh} / \mathrm{kW}$. This is close to the average battery-PV ratio of $9.3 \mathrm{kWh} / \mathrm{kW}_{\mathrm{p}}$ which seems to be standardized, this can be observed in Fig. 4.9 as well, in which can be seen that the majority of the PV projects have roughly the same battery-PV ratio. However, in contrast, this standardization is less pronounced in the number of households which can be served by such a system. For example, the typical $15 \mathrm{~kW}_{\mathrm{p}}$ PV-battery system will be applied for a broad range of households, from 38 up to 172 households. This can be seen in Fig. 4.9 also, in which the boxplots for both the battery-household as for the household-PV ratio show a larger range compared with the range of battery-PV ratio.

Due to these large variations, it is hard to model each individual PV system correctly, therefore the validation of this study will be based on the average values only.

\subsubsection{Model validation}

Compared with the values applied in this study, the average number of households served per $\mathrm{kW}_{\mathrm{p}}$ is roughly $34 \%$ larger: 5.5 households vs. 4.1 households. However, as can be seen from Fig. 4.9, the values from this study correspond well to the values between the first and second quartile based on the data from the PV projects, indicating that the assumed values in this study are on the low side, but realistic. The difference could be related to various factors. It could be related to the projected electricity demand of a household: A lower demand would result in more households which could be served by the same amount of supplied electricity. Besides, it could be that a higher performance ratio of the PV system is 
assumed: A more efficient PV system will supply more electricity per $\mathrm{kW}_{\mathrm{p}}$ and can as such serve more households.

The average battery size in this study is $15.3 \mathrm{kWh} / \mathrm{kW}_{\mathrm{p}}$, based on the PV projects this is found to be $9.3 \mathrm{kWh} / \mathrm{kW}_{\mathrm{p}}$, which is $39 \%$ less. As shown in Fig. 4.9, the battery sizes in this study are larger than the range of values based on the PV projects. This larger battery capacity per installed $\mathrm{kW}_{\mathrm{p}}$ can be largely explained by the lower DOD assumed in this study. A typical DOD for batteries applied by SuryaEnergi is $80 \%$ whereas this study assumes $50 \%$. Taking these differences in DOD into account by estimating the actual battery capacity without the additional capacity required to obtain the preferred DOD, results in a DOD-corrected average battery capacity of $7.6 \mathrm{kWh} / \mathrm{kW}$ and $7.4 \mathrm{kWh} / \mathrm{kW}_{\mathrm{p}}$, for this study and the PV projects, respectively. These values are more in line with each other.

The battery size per household in this study corresponds to a constant of $3.7 \mathrm{kWh}$, since it is modeled as function of the household's electricity demand which is assumed to be constant. The average value found based on the PV projects is $2.1 \mathrm{kWh}$ per household, which is $43 \%$ less compared to the value applied in this study. The values from this study still fall into the range of values found based on the PV projects, however they correspond to the higher end, as can be seen in Fig. 4.9. Again, the DOD influences this ratio. By correcting for the difference in DOD, the battery size per household would be 1.8 and 1.7, for respectively this study and the evaluated PV projects. Besides, with two days, the number of days of autonomy applied by SuryaEnergi is equal to the value applied in this study. So, based on these data, on average the batteries would be able to supply $0.84 \mathrm{kWh}$ per day. In this study this value is estimated to be $0.92 \mathrm{kWh}$, resulting in $0.68 \mathrm{kWh}$ after expected losses (26\%) to meet the daily load.

From previous analysis it seems that the rural electricity demand is modeled in line with the obtained data. Therefore the lower number of households served per installed $\mathrm{kW}_{\mathrm{p}}$ - as discussed earlier - is likely to be related to the lower modeled performance ratio, which is assumed to be $55 \%$ in this study. If instead a PR of $70 \%$ is assumed, the average number of households which could be served per $\mathrm{kW}_{\mathrm{p}}$ would be 5.3 , which corresponds better with the average of 5.5 households which is found by the data analysis from the existing PV projects.

Although the available data are limited and therefore strong conclusions cannot be drawn, the previous analysis shows that the modeling of the PV-battery system sizes and the electricity demand corresponds well to existing off-grid PV projects in Indonesia.

\subsubsection{Cost comparison}

The validation of the cost of off-grid PV is more difficult, because detailed data are lacking. From 17 projects covering 64 off-grid PV systems, only the overall contract value is known, which includes among others a profit margin. Some projects consist of multiple 
identical PV systems, others consist of PV systems with varying sizes. Besides, the locations of the PV systems are geographically distributed. On the one hand, this is beneficial because it represents the variation in costs of the PV systems in Indonesia, on the other hand does this impede a clear comparison of the costs due to the large variety of the underlying data. In addition, the 17 PV projects cover three years in which factors such as costs of PV system components, inflation and competition will have been fluctuating, influencing the contract values over the course of time.

In Fig. 4.10 the contract values ${ }^{15}$ of each of the 17 PV projects of TMLEnergy are shown. The $\mathrm{x}$-axis shows the average PV system size and the number of PV systems within each project. Installed PV system sizes are 15, 20, 30, 50, 100, 125 and $150 \mathrm{~kW}$.

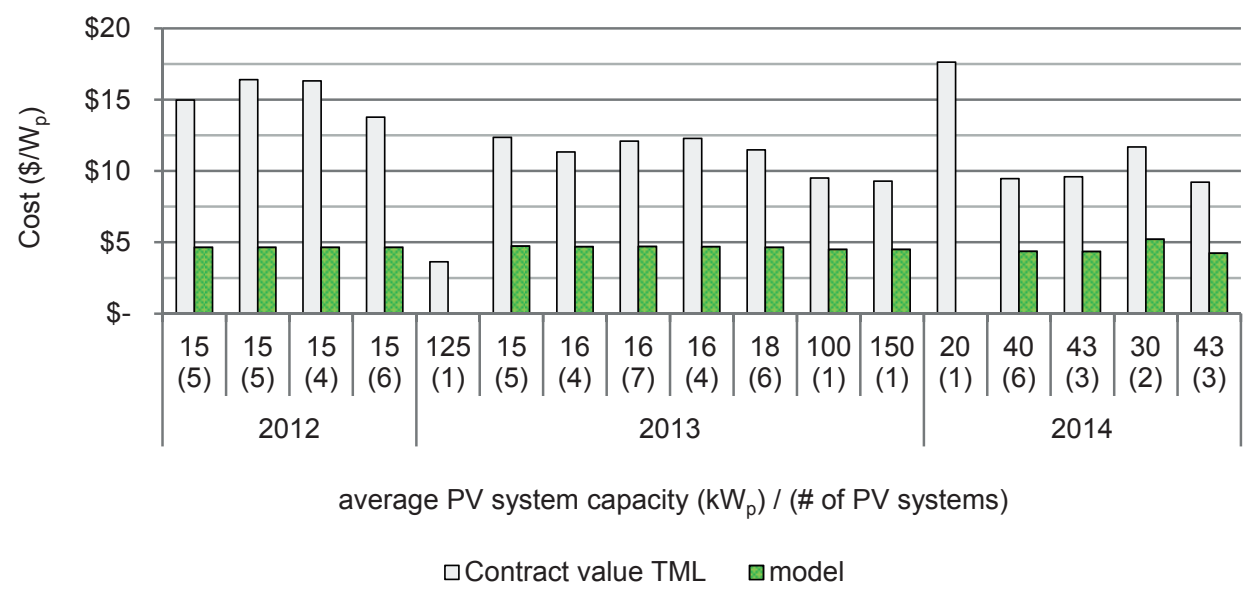

Fig. 4.10. Normalized contract values of various PV systems for 17 PV projects from TML during 2012 - 2014 .

From the data from TMLEnergy - as shown in Fig. 4.10 - a decreasing trend in contract values can be seen, although this could be due to various reasons, it suggests that cost reductions have been made. Besides, rough overall cost estimates for Jakarta from Surya Energi indicates $12.30 \$ / \mathrm{W}_{\mathrm{p}}$, which corresponds to the 2013 contract values of TMLEnergy.

To be able to compare the contract values with the model of this study, the total costs are determined for each project based on the costs for the PV system, batteries and inverters as presented in this study. The sizes of the PV system and batteries are given, the inverter size is determined according to the method described in this study by applying the average number of households served by the particular PV system.

\footnotetext{
15 The contract values in IDR have been converted to USD by applying following exchange rates (IDR/USD) for the years 2012 - 2014: 9,345.79, 10,416.67 and 11,764.71. Source: http://www.usforex.com/forextools/historical-rate-tools/yearly-average-rates.
} 
The modeled stand-alone PV system cost is shown in Fig. 4.10 as well. The average modeled initial investment for these PV systems is $4.42 \$ / \mathrm{W}_{\mathrm{p}}$, which is roughly $40 \%$ of the contract values. This difference is relatively large, however a part could be explained by overhead costs which are ignored in this study. Besides, a profit margin is not taken into account and additional transportation costs for the installation of the PV system are neglected.

The available data give some insight in the costs of off-grid PV systems, however the data are too limited to be able to draw sound conclusions.

\subsection{Limitations of the off-grid PV model}

The LCOE of the off-grid PV systems are compared with the LCOE of diesel generators based on the costs for PLN, which represents the real costs. However, since fuel subsidies exist, the LCOE of the electricity generated by diesel is much less for individual households or companies, making off-grid PV systems financially less attractive for these groups.

The potential of off-grid PV systems is based on the rural households which are categorized as lacking access electricity based on the data from BPS (Fig. 2.2). Another part of the rural households is classified as "other", indicating that they have access to electricity which is not supplied by PLN. These households could be served by stand-alone diesel gensets, in this case the potential of off-grid PV systems could be higher.

For the determination of the LCOE of the hybrid PV systems - which is assumed to be operated inside a micro-grid - the added costs of the infrastructure of the grid itself have been neglected. Including investments in the required infrastructure will increase the final LCOE of this configuration. However, on the other hand, this study neglects economies of scale as well, which could lower the overall cost of the hybrid PV system since one large central PV system could be used instead of interconnected PV systems per household. Besides, from the sensitivity analysis can be seen that even if the investments of the hybrid PV system would be $50 \%$ higher, this would still be cheaper than the reference scenario using diesel only. Moreover, for the reference scenario the grid infrastructure is neglected as well, as such the difference in LCOE will remain approximately the same.

A future study could extend this study to include the modeling of the power distribution line lengths. A methodology similar to that discussed in the study of Ruijven et al. [73] could be used for this purpose.

The LCOE of both off-grid options is still relatively high, therefore micro-hydropower would probably be the most cost-effective solution in suitable areas. The potential of mini/micro-hydro systems in Indonesia is estimated to be roughly $450 \mathrm{MW}$ of which around $85 \mathrm{MW}$ has been installed [112]. Micro-hydro is a proven technology which is reliable and requires little maintenance [36]. When sufficient hydro resources are available, the LCOE of micro hydro is around $0.15 € / \mathrm{kWh}$ [36]. However, micro-hydro is dependent on the availability of sufficient hydro resources near the demand site, since this 
requires a detailed insight in the local hydro resource, this is not taken into account in this study.

The difference in LCOE for the stand-alone option vs. diesel is highly influenced by the additional transportation costs for the fuel use. The final LCOE of electricity generated by diesel is almost linearly related to these fuel costs. The actual difference in LCOE in many remote areas could be significant larger, because these transportation costs are modeled relatively modest.

Besides, the efficiency of diesel generators is assumed relatively high with a range of $20 \%$ - 30\%, especially for times in which the generator is lightly loaded, resulting in lower efficiencies and consequently higher costs. For this range in efficiency the fuel use corresponds to $0.34-0.52 \mathrm{l} / \mathrm{kWh}$, for the $30 \%$ and $20 \%$ efficiency, respectively. Field analysis of PV-diesel systems showed fuel rate values in the range of $0.32-0.75 \mathrm{l} / \mathrm{kWh}$ [113].

The average battery storage size for the stand-alone PV systems is found to be 5.4 times the daily load, which is in the range of 3-10 of typical stand-alone systems [114]. Since the LCOE of the stand-alone system is sensitive to the battery capacity, a larger storage size will increase the LCOE significantly. The same counts for the battery lifetime, which is modeled as five years, but which could be considerably shorter due to the higher operating temperatures in Indonesia [114]. Besides, lacking or wrong maintenance can lead to shorter battery lifetimes. Field data on battery lifetimes in small rural PV applications suggest that a lifetime of 3-4 years is more realistic, although some projects report lifetimes of 6 years [115]. Since the battery related costs form a large part of the final LCOE for stand-alone PV systems and since the LCOE is sensitive to these costs, accurate lifetime prediction is important for the estimation of the real life cycle cost. Batteries are often found one of the key weak links in off-grid energy systems [116]. However, the lifetime depends on a large number of factors such as charge factor, discharge rate, time between full charge and time at low state of charge (SOC) [116]. Therefore, it is recommended for real projects to model the stand-alone system with a high time resolution to simulate the (dis)charge rates and times of full charge and low SOC. In this study there is strived to use most common values for each of the related battery parameters in order to estimate the average capacity and LCOE for such systems.

For simplicity reasons, some parameters which are interconnected are not modeled as such. For instance, the battery lifetime is dependent on the DOD: Increasing the DOD, can lead to a reduction of the battery's lifetime. This relationship is not included in the model, however a DOD less than $80 \%$ is assumed to avoid lifetime reduction in lead-acid batteries [114]. 
Another example is the battery days of autonomy which is modeled such that it influences the battery capacity only, however, in practice, the PV system should be designed slightly larger to be able to charge the larger battery capacity.

Additional transport costs are modeled for the fuel consumption only, since this is required during the whole project's lifetime and these transportation costs will therefore have the highest impact on the cost of fuel. These extra transportation costs will play a role in the construction phase as well adding to the PV system investment costs, however this impact would be smaller compared with the costs of fuel transportation, evaluated over the whole lifetime. The sensitivity analysis shows that the LCOE will increase with 11 and $12 \%$ for an increase in PV system investment costs with 50\%, for the hybrid and standalone configuration, respectively. So, dependent on the location, this could influence the cost-effectiveness, however these investment costs are assumed to decrease due to falling PV module prices.

Overall, the sensitivity analysis shows that the LCOE is sensitive to various parameters. It is recommended to determine the related parameters for a particular project as accurate as possible in order to be able to make a well-based decision, since in some provinces the difference in LCOE between stand-alone PV and diesel gensets is small.

The validation indicates that the sizing of stand-alone PV systems corresponds with real PV projects in Indonesia, although the DOD of the batteries and the PR of the PV system are likely assumed differently. The project data suggests a DOD of $80 \%$ and a PR of roughly $70 \%$, instead of respectively $50 \%$ and $55 \%$ as applied in this study. The actual cost of stand-alone PV systems could not be validated due to the limited information available. Despite this uncertainty in the modeling of the cost, if the DOD and PR are changed to the values based on the real projects, the average LCOE of stand-alone PV systems would be significant lower with on average a LCOE of $0.52 \$ / \mathrm{kWh}$. Compared with the earlier found LCOE of $0.76 \$ / \mathrm{kWh}$, this is a reduction of $32 \%$. However, a higher DOD could lead to a reduction of the battery lifetime, so if a battery lifetime of 3 instead of 5 years is applied, the LCOE increases again to $0.70 \$ / \mathrm{kWh}$.

\subsection{Conclusions}

In most rural parts of Indonesia the LCOE of off-grid PV systems is lower compared with the electricity generation based on diesel gensets with unsubsidized fuel costs. Especially, the hybrid PV configuration - with on average a LCOE of $0.38 \$ / \mathrm{kWh}$ - shows a significant lower LCOE compared with the diesel generated electricity for all provinces. The LCOE of electricity of the stand-alone PV configuration, which is on average 0.76 $\$ / \mathrm{kWh}$, is lower in 25 of the 32 provinces $^{16}$ of Indonesia. Eight of these provinces show a LCOE which is at least $0.05 \$ / \mathrm{kWh}$ cheaper, including the two provinces with the highest

\footnotetext{
${ }^{16}$ Excluding the province of Jakarta, which lacks rural areas
} 
share of households without access to electricity - East Nusa Tenggara and Papua. Besides, in 13 of the 32 provinces the LCOE is only $\pm 0.01 \$ / \mathrm{kWh}$ cheaper (eight provinces) or costlier (five provinces) than electricity generated by diesel, indicating that PV systems are on the edge of becoming cost-effective on large scale. Since it is expected that fuel prices will increase and PV systems will become cheaper, it is expected that this difference in LCOE will change in favor of the PV systems, so that the PV systems will become costeffective in all rural areas.

The potential of off-grid PV systems is $969 \mathrm{GWh} /$ year, of which $566 \mathrm{GWh} /$ year generated inside local grids (PV-battery-diesel) and $403 \mathrm{GWh} /$ year in the form of standalone PV systems (PV-battery). A total nominal power of $816 \mathrm{MW}_{\mathrm{p}} \mathrm{PV}$ systems, $321 \mathrm{MW}$ diesel gensets and $8.5 \mathrm{GWh}$ battery capacities is estimated to be required to achieve $100 \%$ electrification in rural areas. This total capacity of off-grid PV corresponds to 3\% of the grid-connected PV potential of $28 \mathrm{GW}_{\mathrm{p}}$.

To electrify all rural areas in Indonesia by the combination of the proposed hybrid PV micro-grids and stand-alone PV systems, the total cost over 25 years is estimated to be roughly 13 billion US dollars.

On average the LCOE for hybrid PV is $0.38 \$ / \mathrm{kWh}$, for the stand-alone PV system this is $0.76 \$ / \mathrm{kWh}$. Both configurations supply electricity in a cost-effective manner in large parts of Indonesia.

Compared with the LCOE of grid-connected PV for rural areas ranging from 0.17 to $0.24 \$ / \mathrm{kWh}$, off-grid PV systems are significant more expensive.

The hybrid PV system shows the lowest LCOE with the smallest range, but requires a certain population density in order to be feasible. Overall, PV systems are cost-effective in large rural parts in Indonesia already and it is highly likely that this will become the case for all rural areas of Indonesia in the coming years. At the same time, in regions where PV systems are already cost-effective, they will become financially more attractive. 



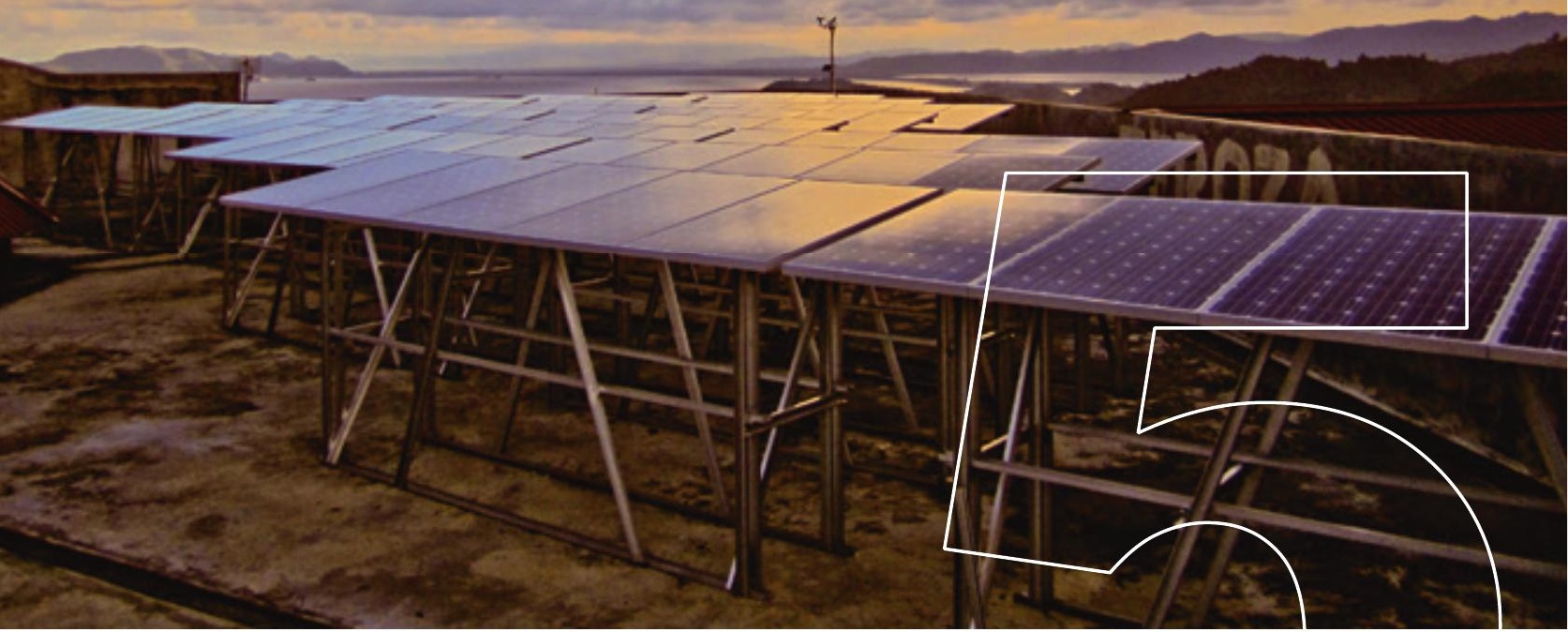

\section{The performance of a grid-} connected PV system in

\section{Jayapura}

Parts of this Chapter have been published in the proceedings of the 27th European Photovoltaic Solar Energy Conference and Exhibition, Frankfurt, 2012. H. Veldhuis, A.H.M.E. Reinders and F.J.A.M. van Houten, Comparison of BIPV Simulation with Monitored Data: The Case of a 35 kWp PV system in Jayapura, Papua, Indonesia, pp. 3971 3974 and in the proceedings of the $40^{\text {th }}$ IEEE Photovoltaic Specialist Conference, Denver, 2014. A.J. Veldhuis and A.H.M.E. Reinders, Performance of a $34 \mathrm{kWp}$ grid-connected PV system in Indonesia - A comparison of tropical and European PV systems, pp. 1978-1981. 


\section{The performance of a grid-connected PV system in Jayapura}

Within the framework of the INDF project a pilot grid-connected PV system has been installed in Indonesia. This chapter describes the design of this system and its performance based on the monitoring data.

\subsection{Introduction}

\subsubsection{Design criteria}

To investigate the performance of PV systems in weak grids in tropical climates, a monitored grid-connected $34 \mathrm{~kW}$ PV system has been installed in Jayapura, the capital of the province of Papua in Indonesia, by the beginning of 2012.

The location of the PV system is very specific due to its remoteness and lack of functional infrastructures for electricity supply and ICT. In Jayapura electricity usually is produced by diesel gensets which feed power in a local grid. Due to the aged gensets and frequent lack of fuel, the city regularly suffers from black-outs ranging from a few minutes to complete days. Because of the abundantly available irradiance, PV systems could provide a sustainable way to improve the security of electricity supply in weak grids like the one in Jayapura.

The PV system research is aimed at:

- Determination of the actual performance of the PV system in comparison to the expected performance.

- Comparison of the performance of this PV system with other PV systems which have been installed in tropical climates and in Europe.

- Evaluation of different PV technologies like crystalline and thin film modules in one PV system.

- Evaluation of temperature losses in a tropical climate in different PV technologies.

- Evaluation of the effect on the system's performance by the use of central inverter vs micro-inverters.

- Evaluation of the influence of the power quality of the grid on the PV system. 


\subsubsection{Research questions}

The central research question in this chapter is: What is the performance of a gridconnected PV system in Indonesia?

This research question can be divided into the following sub questions:

- How well do PV systems perform in Indonesia compared with PV systems in Western countries?

- What is the influence of the temperature on the power output?

- How many black-outs occur and what is the average time of a blackout?

- What is the influence of these black-outs on the energy yield of PV systems?

Based on this pilot PV system and values found in literature, these questions will be answered.

\subsubsection{Outline}

In the next section the PV and monitoring system will be described in detail. This is followed by a section presenting the performance evaluations of the PV system. The chapter will close with a discussion and conclusions.

\subsection{System description}

\subsubsection{PV system design}

The PV system is installed on the roof of the district office in Jayapura (see Fig. 5.1 and Fig. 5.2), close to the equator ( $\left.2^{\circ} 33^{\prime} \mathrm{S}, 140^{\circ} 41^{\prime} \mathrm{E}\right)$.

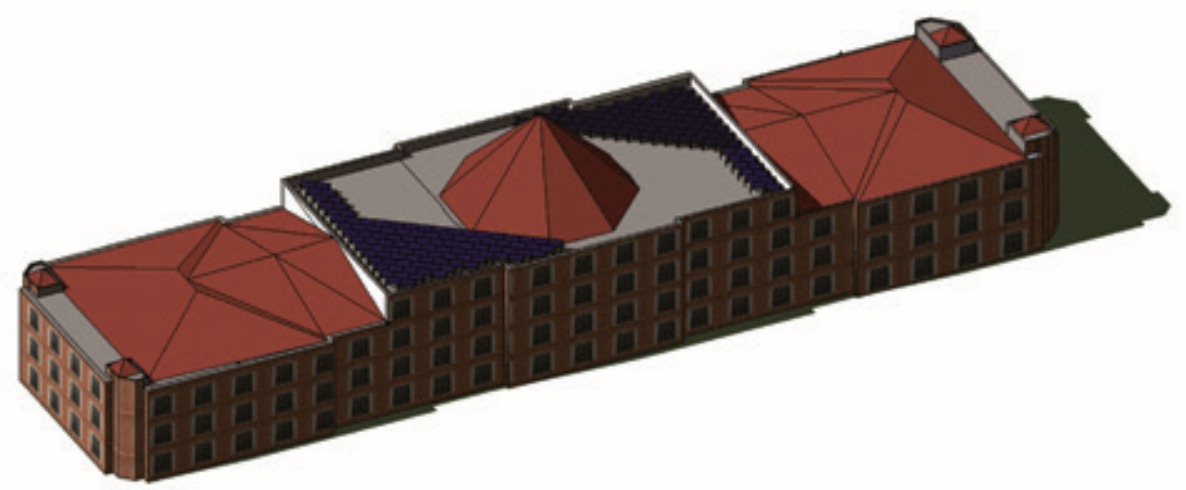

Fig. 5.1. 3D render of the district office in Jayapura with the rack-mounted PV modules on top of the roof. 


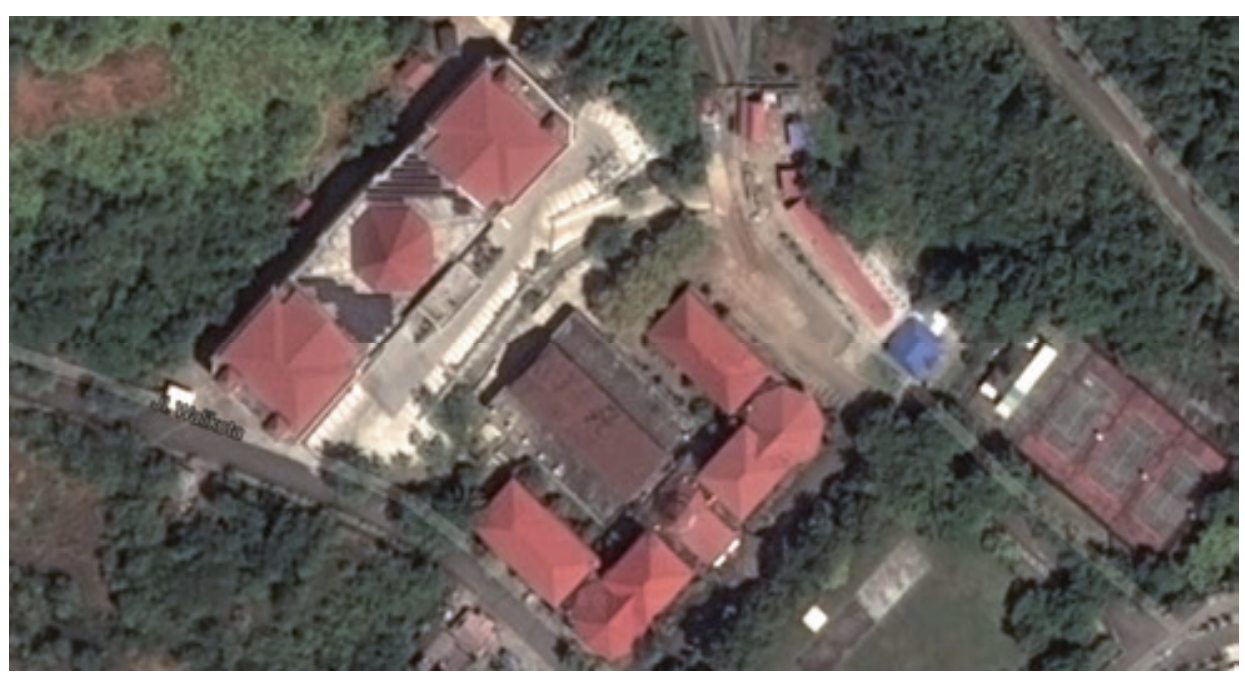

Fig. 5.2. Aerial view of the district office in Jayapura. Images (C2014 CNES / Astrium, Map data (C)2014 Google.

The PV system consists of four arrays and two types of PV modules totaling to 34.08 $\mathrm{kW}_{\mathrm{p}}$, which is schematically shown in Fig. 5.3.

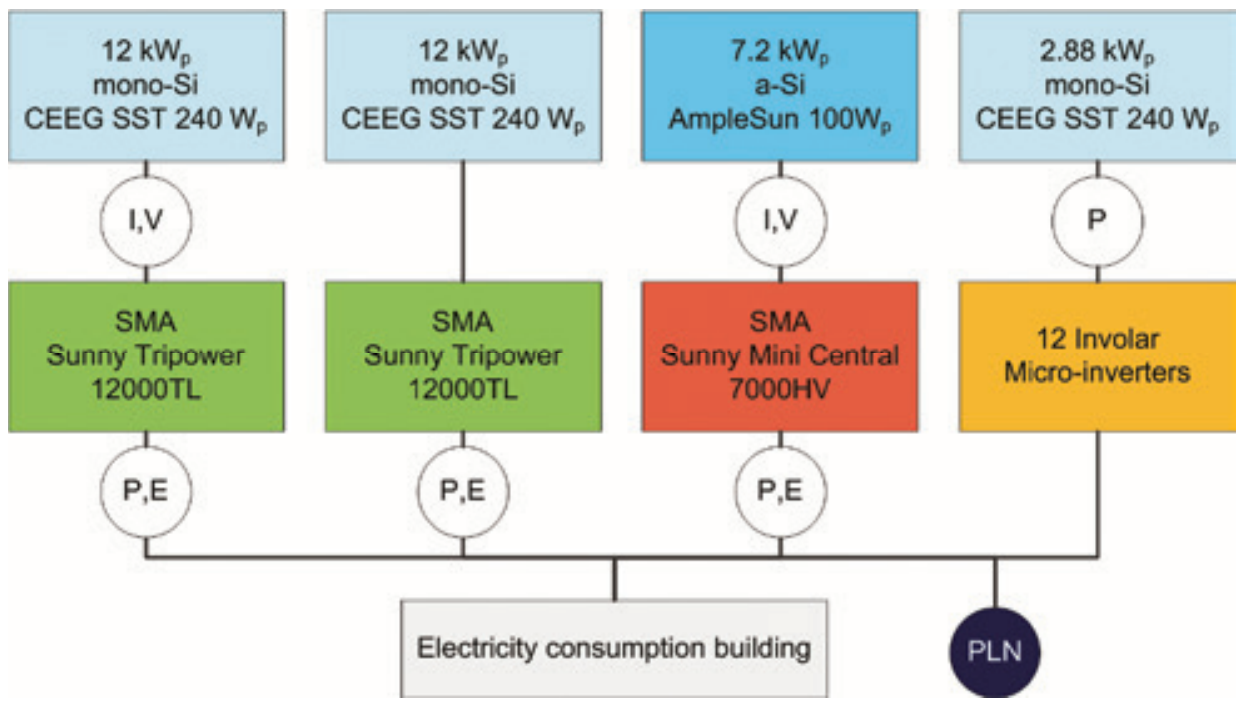

Fig. 5.3. Schematic diagram of the PV system in Jayapura including connections and locations of monitoring.

The first two arrays consist of fifty $240 \mathrm{~W}_{\mathrm{p}}$ CEEG SST240-60M mono-crystalline silicon PV modules (see Appendix B.1 for details) - totaling to $12 \mathrm{~kW}_{\mathrm{p}}$ - connected to a SMA Sunny Tripower $12000 \mathrm{TL}^{17}$ inverter. The third array consists seventy-two $100 \mathrm{~W}_{\mathrm{p}}$ ASF

\footnotetext{
${ }^{17}$ Transformerless
} 
100 thin film amorphous silicon PV modules (see Appendix 0 for details) - totaling to 7.2 $\mathrm{kW}_{\mathrm{p}}$ - connected to a SMA Sunny Mini Central 7000HV inverter and the fourth array consists of twelve mono-crystalline silicon PV modules - totaling to $2.88 \mathrm{~kW}_{\mathrm{p}}$ - individually connected to Involar micro-inverters. The latter mono-crystalline PV modules are identical to the PV modules applied in the first two arrays.

All PV modules are tilted $10^{\circ}$ to the North, in Fig. 5.4 photos of the PV modules on the roof are shown.
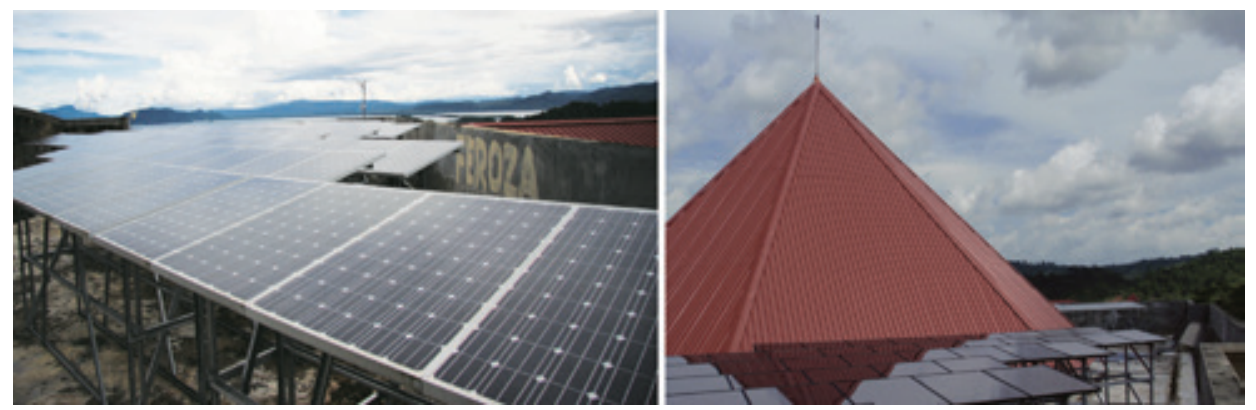

Fig. 5.4. Photo of the rack-mounted mono-crystalline silicon PV modules (left) and amorphous silicon PV modules (right) on the roof of the district office in Jayapura.

The PV system supplies electricity to the district office of Jayapura which is connected to the local electricity grid of the Indonesian electricity company, PLN. If the grid experiences a blackout, or the frequency or voltage of the grid exceeds a certain range, the inverters of the PV system disconnect from the grid, causing the PV system to be offline.

Based on initial calculations, assuming a $35 \mathrm{~kW}_{\mathrm{p}}$ PV system, a PR of $78 \%$ and an annual irradiation of $1,898 \mathrm{kWh} / \mathrm{m}^{2} /$ year, it is expected that the total PV system will produce an annual amount of approximately $51,800 \mathrm{kWh}$ electricity.

\subsubsection{Monitoring system}

In Fig. 5.5 a detailed scheme of the grid-connected PV system including monitoring sensors is shown. The monitoring system measures the following variables on specific locations in the PV system: current $I(\mathrm{~A})$, voltage $V(\mathrm{~V})$, temperature $T\left({ }^{\circ} \mathrm{C}\right)$, see Fig. 5.5 .

From two of the three strings of the first Sunny Tripower (STP1) PV array, the current and voltage are measured: From a string with twenty and from a string with ten PV modules. Besides, from one PV module in both of these monitored PV strings, the temperature is measured at the back of the PV module.

From the Sunny Mini Central (SMC) PV array the current and voltage is measured from one PV string which consists of three parallel connected strings with six PV modules each. From another similar string only the current is measured and from one PV module inside the SMC PV array the temperature is recorded. 


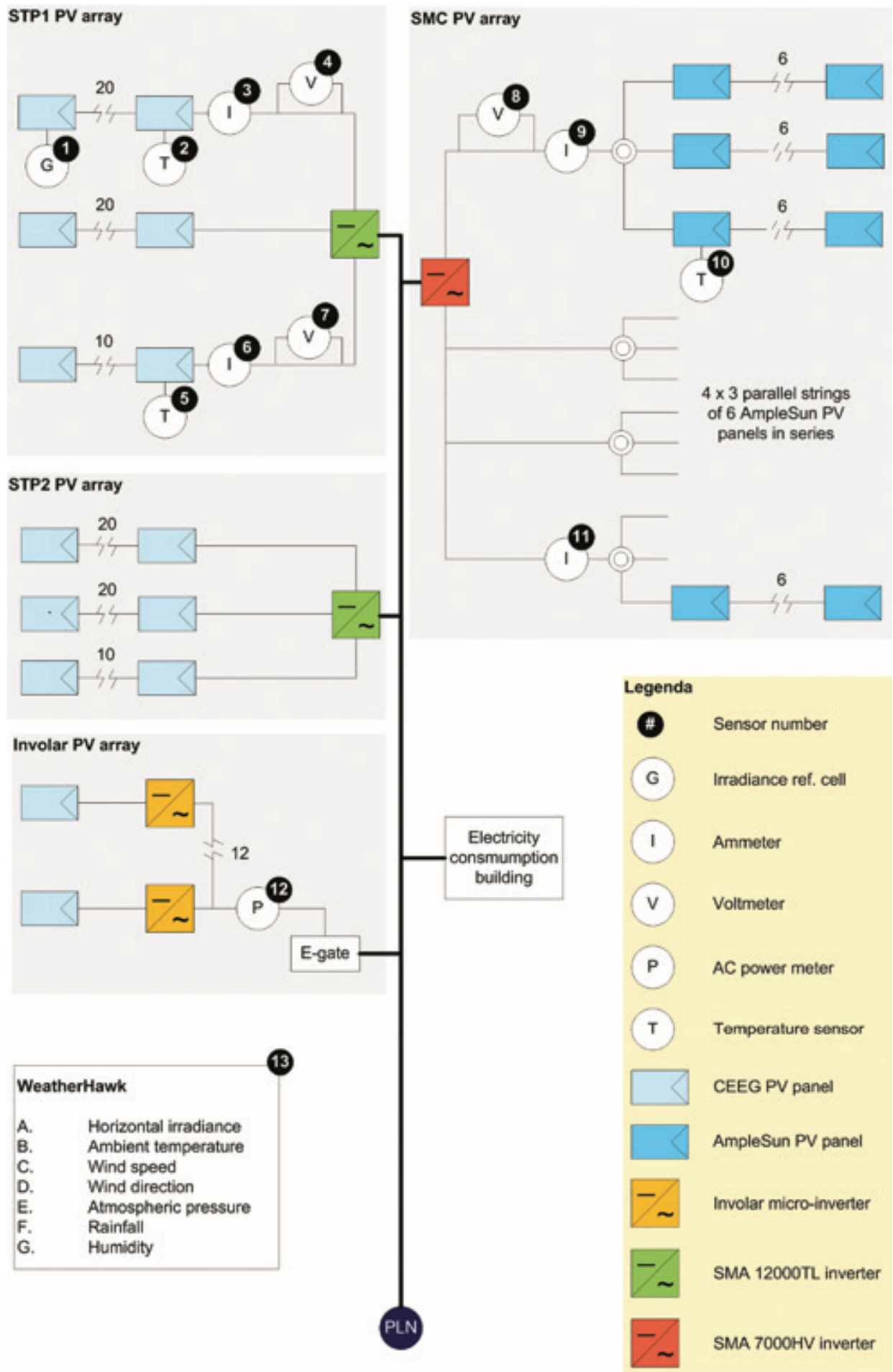

Fig. 5.5. Scheme of the $34 \mathrm{~kW}_{\mathrm{p}}$ grid-connected PV system and its monitoring set-up. 
From the Involar PV array, only the total AC power of the twelve PV modules is monitored before the actual connection to the grid.

Besides, the power and electricity generation are recorded by the inverters itself by the socalled SMA WebBox. So, although the second Sunny Tripower (STP2) PV array is not measured separately at the DC side, the total power and energy of this array can be obtained via the WebBox.

In addition, a meteorological station from Campbell Scientific, the WeatherHawk 232, is located on the same roof, measuring: global horizontal irradiance, ambient temperature, wind speed and its direction, relative humidity, rainfall and air pressure. A separate in-plane silicon reference cell is installed next to one of the PV modules to measure the tilted irradiance.

A data logger from Campbell Scientific, the CR3000, has been applied to read and record the various sensor signals. The data logger samples every second and records every minute.

Details about all measured variables by the data logger are shown in Table 5-1.

TABLE 5-1: MEASURED VARIABLES BY DATA LOGGER

\begin{tabular}{llllr}
\hline Sensor \# & Variable & Description & Unit & Accuracy \\
\hline 1 & $G_{t}$ & Global tilted irradiance & $\mathrm{W} / \mathrm{m}^{2}$ & $5 \%$ \\
\hline 2 & $T_{m-x, 1}$ & Temperature mono-Si PV module & ${ }^{\circ} \mathrm{C}$ & $0.2^{\circ} \mathrm{C}$ \\
\hline 3 & $I_{d c-x, 1}$ & DC current from mono-Si PV string 1 & $\mathrm{~A}$ & $0.2 \%$ \\
\hline 4 & $V_{d c-x, 1}$ & DC voltage from mono-Si PV string 1 & $\mathrm{~V}$ & $0.2 \%$ \\
\hline 5 & $T_{m-x, 2}$ & Temperature mono-Si PV module & ${ }^{\circ} \mathrm{C}$ & $0.2^{\circ} \mathrm{C}$ \\
\hline 6 & $I_{d c-x, 2}$ & DC current from mono-Si PV string 2 & $\mathrm{~A}$ & $0.2 \%$ \\
\hline 7 & $V_{d c-x, 2}$ & DC voltage from mono-Si PV string 2 & $\mathrm{~V}$ & $0.2 \%$ \\
\hline 8 & $V_{d c-a}$ & DC voltage from a-Si PV string 1 & $\mathrm{~V}$ & $0.2 \%$ \\
\hline 9 & $I_{d c-a, 1}$ & DC current from a-Si PV string 1 & $\mathrm{~A}$ & $0.2 \%$ \\
\hline 10 & $T_{m-a}$ & Temperature a-Si PV module & ${ }^{\circ} \mathrm{C}$ & $0.2^{\circ} \mathrm{C}$ \\
\hline 11 & $I_{d c-a, 2}$ & DC current from a-Si PV string 2 & $\mathrm{~A}$ & $0.2 \%$ \\
\hline 12 & $P_{a c-\mu}$ & AC power from 12 micro-inverters & $\mathrm{W}$ & - \\
\hline $13 \mathrm{~A}$ & $G_{b}$ & Global horizontal irradiance & $\mathrm{W} / \mathrm{m}^{2}$ & $2.5 \%$ \\
\hline $13 \mathrm{~B}$ & $T_{a}$ & Ambient temperature & ${ }^{\circ} \mathrm{C}$ & $0.5^{\circ} \mathrm{C}$ \\
\hline $13 \mathrm{C}$ & $v_{w}$ & Wind speed at PV module height & $\mathrm{m} / \mathrm{s}$ & - \\
\hline $13 \mathrm{D}$ & $\theta$ & Wind direction & ${ }^{\circ}$ & $0.01^{\circ}$ \\
\hline $13 \mathrm{E}$ & $p_{a t m}$ & Atmospheric pressure & $\mathrm{Pa}$ & $1.5 \%$ \\
\hline $13 \mathrm{~F}$ & $r a i n$ & Rainfall & $\mathrm{mm}$ & $1 \mathrm{~mm}$ \\
\hline $13 \mathrm{G}$ & $R H$ & Relative humidity & $5 \%$ \\
\hline
\end{tabular}


The WebBox monitors some variables for each SMA inverter, among others: real AC power (W), grid frequency $(\mathrm{Hz})$, grid phase voltage $(\mathrm{V})$, string current $(A)$, string voltage $(\mathrm{V})$ and the total electricity production $(\mathrm{kWh})$. It records every 10 minutes $^{18}$ as long as at least one of the SMA inverters is online ${ }^{19}$.

\subsection{Performance of the PV system}

The performance of the PV system is discussed for various time-scales. First, results are presented showing the trend over a course of a day. Then the energy yields and performances of the various subsystems for a specific month are discussed, which is followed by an overview of the monthly performances covering a complete year.

\subsubsection{Daily performance}

In Fig. 5.6 the average, minimum and maximum minutely averaged global horizontal irradiance $\left(\mathrm{W} / \mathrm{m}^{2}\right)$ is plotted for each minute of a day, based on measurements during the month of September 2013. The average daily irradiation during this month is $5.5 \mathrm{kWh} / \mathrm{m}^{2}$.

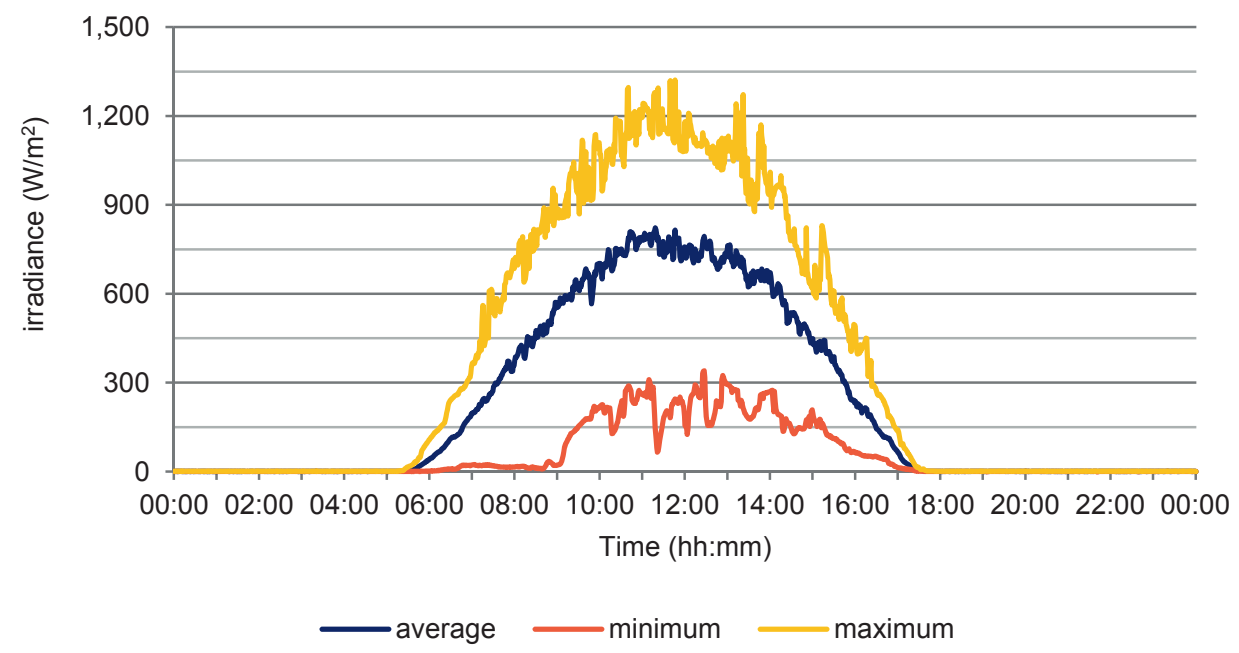

Fig. 5.6. Average, minimum and maximum minutely averaged global horizontal irradiance $\left(\mathrm{W} / \mathrm{m}^{2}\right)$ measured during the month of September 2013.

\subsubsection{Monthly performance}

In this section the results for one month are shown, the results for other months can be found in Appendix C, the definitions used to calculate the various figures can be found here as well.

\footnotetext{
${ }^{18}$ To obtain more detailed information this recording interval has been changed to a 5-minute interval during a field visit on the 14th of November 2013.

${ }^{19}$ An inverter will be online if and only if there is enough irradiance to produce power and if the grid conditions allow the inverter to connect to the grid.
} 
In Table 5-2 the energy yields of the different subsystems are shown for the month of September 2013. It shows the monitoring fraction $M F(\%)$, the system availability $B F(\%)$, the total irradiation $H_{i, u}\left(\mathrm{kWh} / \mathrm{m}^{2}\right)$, the DC energy of the array measured by the data logger $E_{A, D L}(\mathrm{kWh})$ and measured by the WebBox $E_{A, W B}(\mathrm{kWh})$, the AC energy fed into the grid based on measurements from the WebBox $E_{F I}(\mathrm{kWh})$ and the DC energy lost due to the temperature effect $E_{L T}(\mathrm{kWh})$.

The monitoring fraction is the part of useful measurements and excludes monitoring errors and missing records. For the Involar system, negative measured values for the AC power are assumed to be monitoring errors, although this could be caused by grid instability as well. Since the AC power is the only measured variable, the exact reason cannot be determined. The monitoring fraction for September is equal for all subsystems and is $98 \%$.

The system availability factor shows the fraction of the time in which the PV array is producing power during day-light time. This is based on the measurements from the WebBox, which records only if one of the SMA inverters is online. Therefore is assumed that each record that is missing indicates system offline time if no electricity has been added to the total electricity production in the meantime. For September each subsystem has an equal availability of $90 \%$.

Although the Involar system is not connected to the WebBox, it is assumed that the same offline time applies for the Involar system, since other information about this system is lacking.

The total irradiation received by the PV array includes only the times in which the PV subsystem is available/online, besides records with errors are excluded. Therefore the overall irradiation received during the evaluated period can be larger than shown in Table 5-2. Since the system availabilities are equal, each subsystem received a total irradiation of 145 $\mathrm{kWh} / \mathrm{m}^{2}$.

Since the voltage and current at the DC side of the STP PV arrays are only measured at two of the three PV strings of the STP1 PV array, it is assumed that the voltage and current in the non-measured PV string, consisting of twenty PV modules, is equal to the other identical PV string. In this way it is possible to compare the DC energy recorded by the data logger with the DC energy from the WebBox.

The STP2 PV array is not measured at all by the data logger, therefore it is assumed that the DC energy of this array equals the DC energy of the STP1 array in order to be able to compare this with the DC energy recorded by the WebBox. Besides, the $E_{L T}$ value for the STP1 array is based on the first measured PV module temperature and for the STP2 array it is based on the second one. 
For the SMC PV array a similar approach has been used, the total DC power from this array is determined as follows:

$$
P_{d c, S M C}=2 \mathrm{~V}_{d c-a}\left(\mathrm{I}_{d c-a, 1}+\mathrm{I}_{d c-a, 2}\right)
$$

In this way, the DC energy from the SMC array can be compared with the DC energy from the WebBox.

TABLE 5-2: ENERGY YIELDS OF DIFFERENT SUBSYSTEMS FOR SEPTEMBER 2013

\begin{tabular}{|c|c|c|c|c|c|c|c|}
\hline PV array & $\begin{array}{r}\text { MF } \\
\%\end{array}$ & $\begin{array}{r}\text { BF } \\
\%\end{array}$ & $\begin{array}{r}\mathrm{H}_{\mathrm{i}, \mathrm{u}} \\
\mathrm{kWh} / \mathrm{m}^{2}\end{array}$ & $\begin{array}{l}\mathrm{E}_{\mathrm{A}, \mathrm{DL}} \\
\mathrm{kWh}\end{array}$ & $\begin{array}{l}E_{A, W B} \\
k W h\end{array}$ & $\begin{array}{r}\mathrm{E}_{\mathrm{FI}} \\
\mathrm{kWh}\end{array}$ & $\begin{array}{r}\mathrm{E}_{\mathrm{LT}} \\
\mathrm{kWh}\end{array}$ \\
\hline STP1 & \multirow{3}{*}{98} & 90 & 145 & \multirow{2}{*}{1,235} & 1,208 & 1,166 & 117 \\
\hline STP2 & & 90 & 145 & & 1,382 & 1,342 & 125 \\
\hline SMC & & 90 & 145 & 1,008 & 952 & 907 & 46 \\
\hline Involar & 98 & 90 & 145 & 240 & - & - & 24 \\
\hline
\end{tabular}

In Table 5-3 some key figures of the different subsystems are shown for the month September 2013. The DC efficiency $\eta_{D C}(\%)$ of both STP arrays is based on the DC current and DC voltage measurements of the two strings of the STP1 array.

The temperature-corrected DC efficiency $\eta_{D C, 25}(\%)$ represents the efficiency of the PV array without temperature losses, based on measurements from the data logger. Since the temperature is measured for two mono-crystalline PV modules, the $\eta_{D C, 25}$ for STP1 is based on the first PV module temperature and the $\eta_{D C, 25}$ for STP2 is based on the second PV module temperature.

The inverter efficiency $\eta_{i n v}(\%)$, the system efficiency $\eta_{s y s}(\%)$ and the performance ratio PR (\%) of the STP and SMC arrays are based on measurements from the WebBox. For the Involar system the latter two values are based on measurements from the data logger.

TABLE 5-3: KEY FIGURES OF DIFFERENT SUBSYSTEMS FOR SEPTEMBER 2013

\begin{tabular}{lrrrrrr}
\hline PV array & $\begin{array}{rrrrr}\boldsymbol{\eta}_{\text {dc }} \\
\%\end{array}$ & $\begin{array}{r}\boldsymbol{\eta}_{\text {dc,25 }} \\
\%\end{array}$ & $\begin{array}{r}\boldsymbol{\eta}_{\text {inv }} \\
\%\end{array}$ & $\begin{array}{r}\boldsymbol{\eta}_{\text {sys }} \\
\%\end{array}$ & $\begin{array}{r}\text { PR } \\
\%\end{array}$ & $\begin{array}{r}\text { PR } \\
\%\end{array}$ \\
\hline STP1 & 10.9 & 12.0 & 96.5 & 11.0 & 67.2 & - \\
\hline STP2 & 10.9 & 12.1 & 97.1 & 12.7 & 77.3 & - \\
\hline SMC & 5.8 & 6.0 & 95.2 & 5.5 & 87.1 & $72.6^{*}$ \\
\hline Involar & - & - & - & 9.0 & 55.0 & $60.1^{+}$ \\
\hline
\end{tabular}

"If PR of SMC is based on $120 \mathrm{~W}_{\mathrm{p}}$ (initial) instead of $100 \mathrm{~W}_{\mathrm{p}}$ (stabilized) PV modules.

+If all errors are due to grid instability. 
As can be seen from Table 5-3, the inverter efficiency of the STP1 is slightly smaller compared with STP2. The system efficiency and the PR of the STP1 array are significant less compared with the STP2 array. This can be seen in Table 5-2 as well, in which the DC energy based on the WebBox, $E_{A, W B}$, shows a smaller value for the STP1 array compared with the STP2 array, although the system availability is equal.

Records in which the AC power output is less than $1 \mathrm{~W}$ and the irradiance exceeds 10 $\mathrm{W} / \mathrm{m}^{2}$ are considered faulty. According to this definition, data analysis showed that the STP1 array experienced faults during 2,720 records, corresponding to 45 hours. In contrast, during the same period, the STP2 array showed only 70 records which are considered as faulty, which corresponds to roughly one hour. It is unclear why the STP1 inverter shows more errors than the STP2 inverter.

The inverter efficiency of the SMC array is slightly less compared with the STP inverters, however the PR is significant larger.

The system efficiency of the Involar array is somewhat smaller compared with the STP arrays and this Involar array shows the lowest PR of all.

Sometimes the Involar system experiences faults, therefore the performance is lower compared to the other PV systems. It is difficult to determine the exact cause of this anomaly. Usually this type or errors are caused by either a failing PV system, in particular the inverter(s) or a malfunctioning monitoring system. Observations during the visit in November 2013 show that the Involar system is in disable mode for some moments during the day. During this period, the data logger records small negative values, comparable with the erroneous values seen in the monitoring data. Based on these observations, it is assumed that the Involar system is not available and not producing power. Because the Involar system contributes only $2.88 \mathrm{~kW}_{\mathrm{p}}$ to the total installed capacity of $34.08 \mathrm{~kW}_{\mathrm{p}}$ of the PV system, the influence on the total power output is minor. The energy loss due to these faults is assumed to be in the order of $53 \mathrm{kWh}$, corresponding to about $1.5 \%$ of the total AC energy production in the month of September.

In Fig. 5.7 the inverter efficiencies of the three subsystems are shown. From approximately $15 \%$ of its total nominal power, the inverter efficiencies of both STP arrays show constant values around 97\%. For the SMC inverter this trend is the same, however it starts from $20 \%$ of its total nominal power and the inverter efficiency remains constant around $96 \%$. 

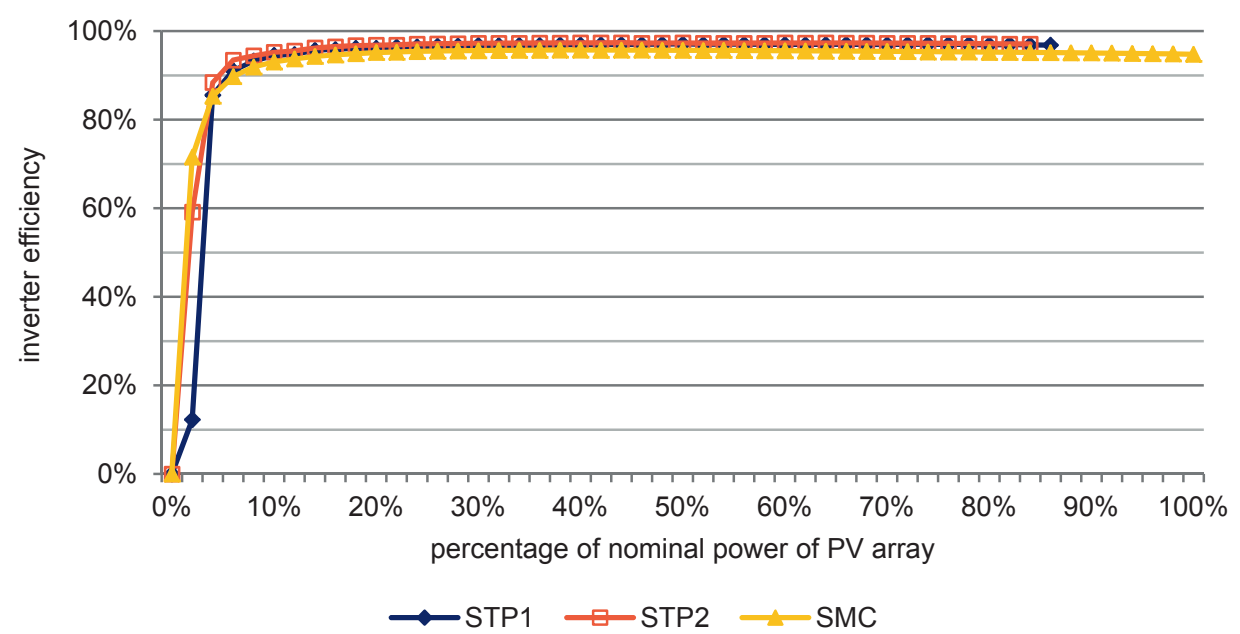

Fig. 5.7. Inverter efficiencies as function of the array power, 50 linearly divided power classes, based on measurements from the WebBox.

From Fig. 5.7 can be observed that about $85 \%$ of the nominal power of the PV array is reached for the STP arrays. For the SMC array, approximately $100 \%$ of the nominal power is reached.

In Fig. 5.8 the temperature-corrected DC-efficiencies are shown for the SMC and both STP PV arrays for irradiance bins of $50 \mathrm{~W} / \mathrm{m}^{2}$. In total 33 records, corresponding to $0.08 \%$ of all records, with an irradiance exceeding $1,200 \mathrm{~W} / \mathrm{m}^{2}$ are excluded from this figure, since these values are disputable.

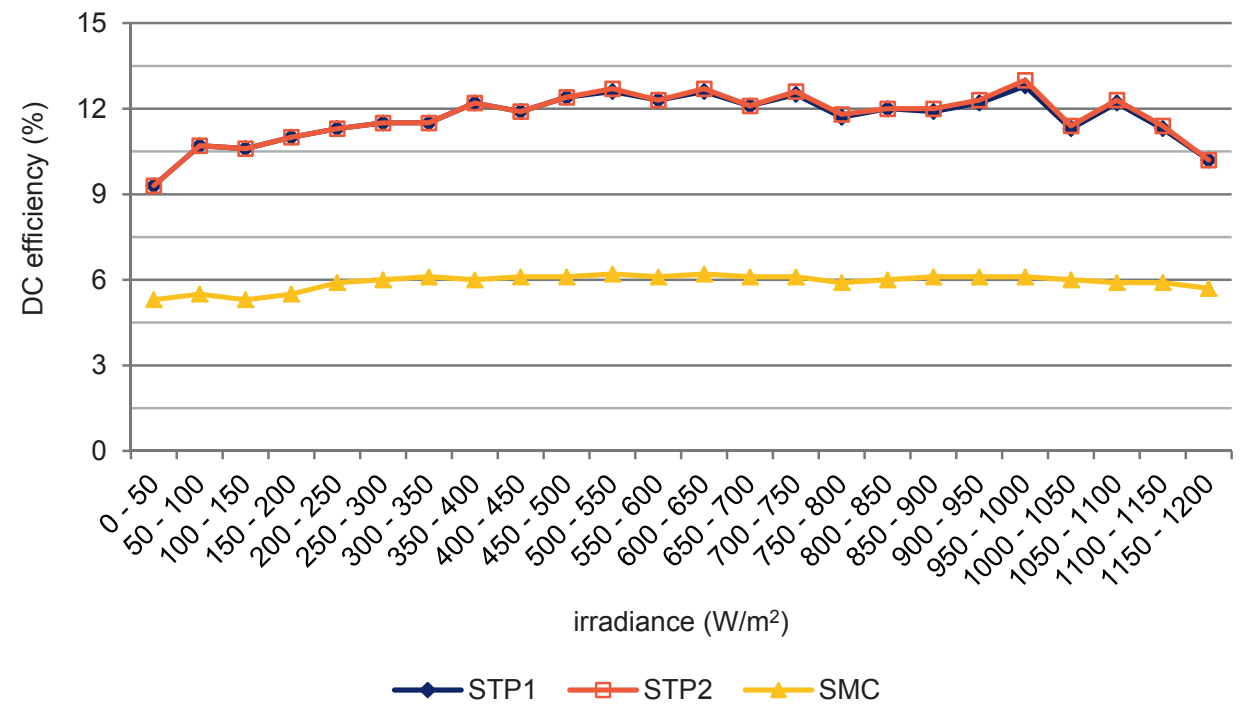

Fig. 5.8. Average, temperature-corrected DC-efficiency as function of the irradiance per range of 50 $\mathrm{W} / \mathrm{m}^{2}$ 
From Fig. 5.8 can be seen that the DC efficiency of the SMC PV array stays more constant over the range from $250-1,200 \mathrm{~W} / \mathrm{m}^{2}$ than the efficiency of the STP arrays. The DC efficiencies of the STP arrays show a similar trend, increasing slightly until it drops after $1,000 \mathrm{~W} / \mathrm{m}^{2}$. This drop can be observed in a lesser extent in the DC efficiency of the SMC PV array as well and might be related to the PV module temperatures (see Fig. 5.9), which show a similar but opposing trend around these irradiance levels.

In Fig. 5.9 the temperature rise over ambient is shown for the three measured PV module temperatures for irradiance bins of $50 \mathrm{~W} / \mathrm{m}^{2}$. As can be seen, the PV module temperature is nearly linearly related to the irradiance. However, for the highest irradiance range $\left(G_{h o r}>\right.$ $1,050 \mathrm{~W} / \mathrm{m}^{2}$ ), the PV module temperatures deviate from this trend. This is probably caused by the thermal inertia of the PV modules in combination with fluctuating irradiance levels, resulting in only short periods of time in which the irradiance reaches these higher levels. Besides, with a higher temperature rise over ambient, the influence of the wind on the PV module temperature will get more pronounced, which likely causes deviations from this linear trend.

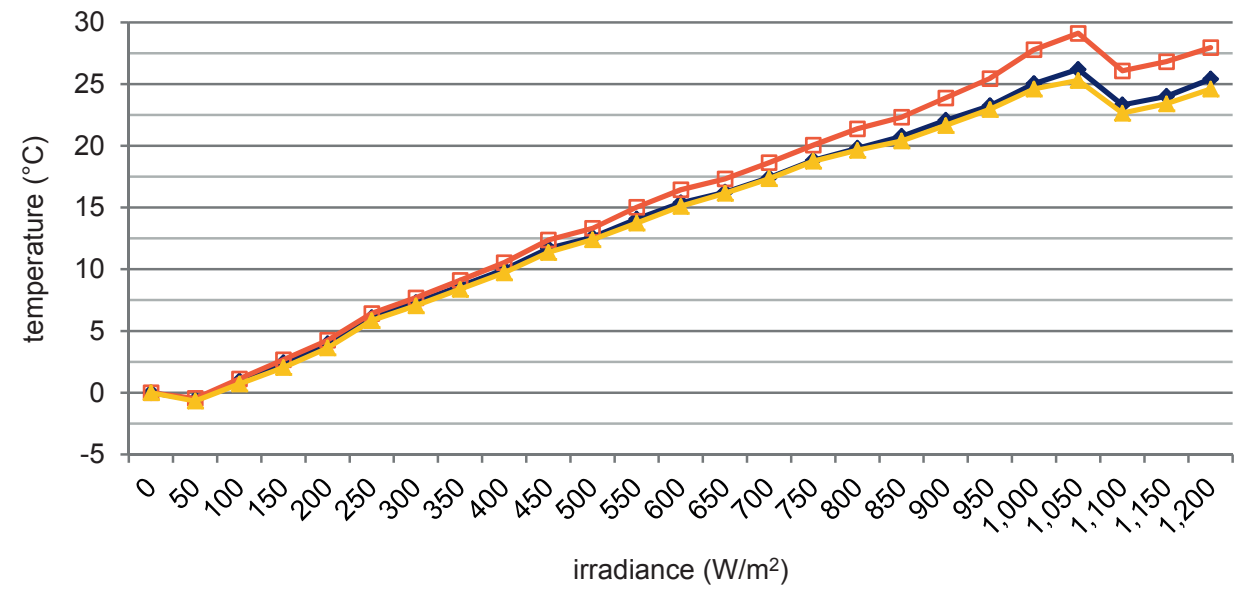

$\longrightarrow$ Tm-x,1 $\because \mathrm{Tm}-\mathrm{x}, 2 \longrightarrow \mathrm{Tm}-\mathrm{a}$

Fig. 5.9. Difference in temperature between the PV modules and ambient as function of the irradiance per range of $50 \mathrm{~W} / \mathrm{m}^{2}$

\subsubsection{Year}

In Fig. 5.10 the performance ratios (PR) for the four arrays are shown, based on measurements during a complete year from May 2013 to April 2014. According to the standards for analytical monitoring of JRC [79] and the Dutch guidelines for gridconnected PV systems [80], data during system unavailability are excluded from analysis, therefore the total irradiation during these months is higher than shown in Fig. 5.10. 
From May 2013 - April 2014 in total 43.0 MWh has been produced of which 40.7 MWh by the SMA inverters. Early findings showed an average daily electricity production of $114 \mathrm{kWh}$ per day [117]. The average daily electricity production calculated for these SMA inverters during the complete period is $111 \mathrm{kWh}$, which is in line with the expectations. The total measured irradiation during this period is $1,534 \mathrm{kWh} / \mathrm{m}^{2}$, however the actual irradiation was higher, because the measurements do not cover the complete time period. This counts in particular for the months June and April and in a lesser extent for December and February, which can be observed in Fig. 5.10 as well.

Based on the measurements the average daily irradiation per month is determined, which is used to estimate the total irradiation during the period, including the time with missing and erroneous records. The total irradiation during May 2013 - April 2014 is estimated to be $1,764 \mathrm{kWh} / \mathrm{m}^{2}$, which corresponds to $4.8 \mathrm{kWh} / \mathrm{m}^{2} / \mathrm{d}$.

As can be seen in Fig. 5.10, the Sunny Mini Central (SMC) array performs the best with an average PR of $91 \%$; however, this could be influenced by the higher initial efficiency (8.3\%) of the amorphous silicon modules; for the calculation of the PR the stabilized efficiency of $6.3 \%$ is applied.

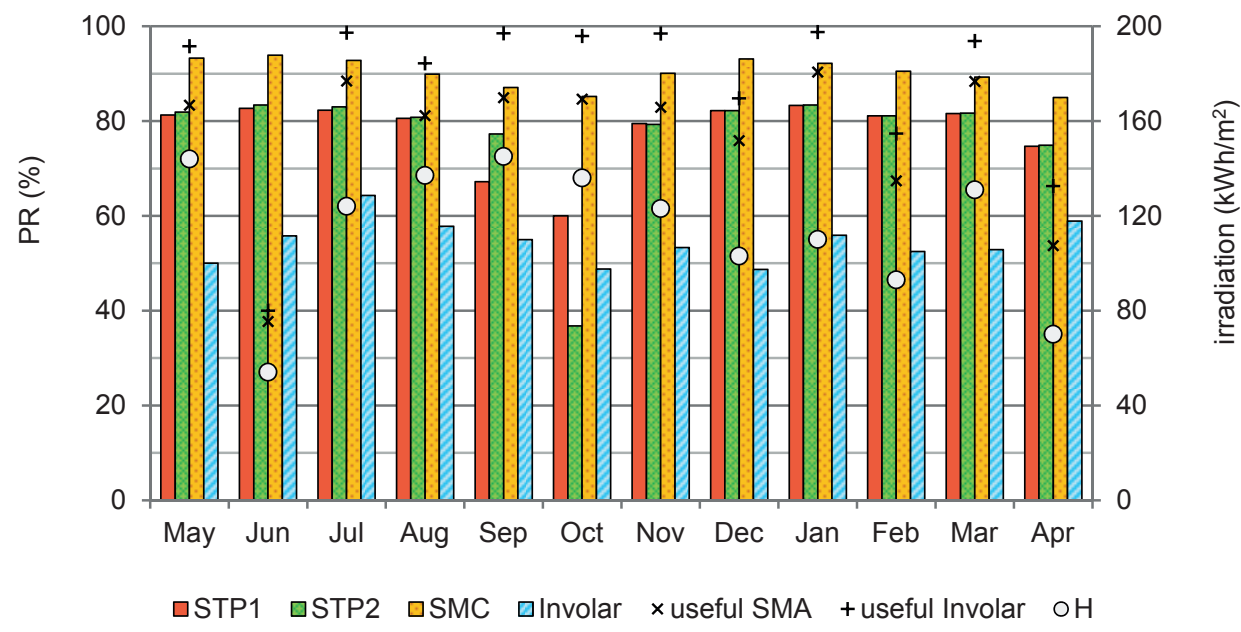

Fig. 5.10. The PR of the four arrays of the PV system and the total irradiation in Jayapura per month from May 2013 - April 2014.

Overall, the PRs of the first and second STP PV array are similar, with averages of 78\% and $79 \%$, respectively. The Involar system has the lowest performance with an average PR of 54\%. Furthermore, both STP arrays show a lower PR in the month October, however although both arrays are identical - the STP2 array shows a significantly lower PR compared with the first STP array. 
The overall system efficiency of the SMA PV arrays can be estimated by dividing the total AC energy produced, as recorded by the $\mathrm{WebBox}^{20}$, by the total estimated irradiation received per month, as discussed before. In contrast to the system efficiency calculated according to the monitoring guidelines, this overall efficiency includes all energy losses due to system faults or grid instability. Both system efficiencies are shown in Fig. 5.11 for May 2013 - April 2014.

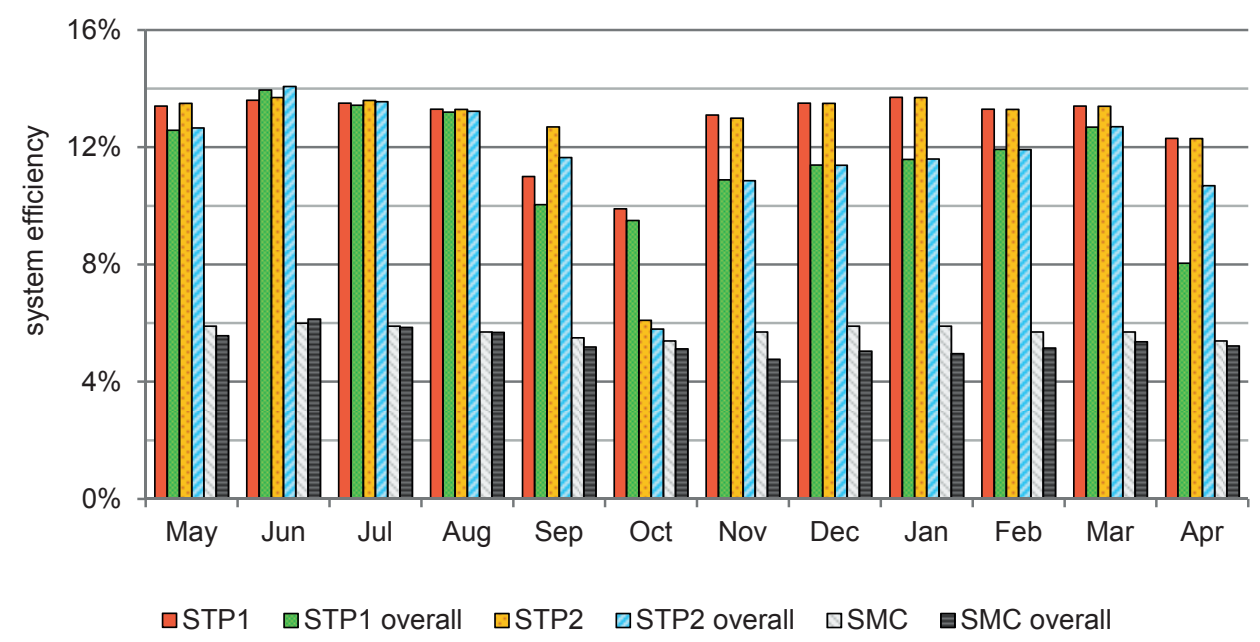

Fig. 5.11. Overall system efficiency of the SMA PV arrays for the months May 2013 - April 2014.

In Fig. 5.12 the time periods of system faults per array are shown. Interesting observation is the large rise of the time that the STP2 array experiences faults in October. This counts for the STP1 array in a lesser extent as well, however in the month September it shows a higher fault time compared with STP2 array. This can also be perceived in Fig. 5.10 in which the PR of both arrays is lower in the months of September and October. The fault time is based on the records in which the AC power output is less than $1 \mathrm{~W}$, for irradiance levels of $G_{h o r}>10 \mathrm{~W} / \mathrm{m}^{2}$. The causes of these faults are unknown and are hard to find with the available monitoring data. These faults could be related to external sources, like the grid frequency, or to causes inside the PV system itself, such as hardware errors of the inverter.

\footnotetext{
${ }^{20}$ The WebBox records the total energy produced $(\mathrm{kWh})$ as well; therefore the total monthly energy production can be determined even if some records are missing.
} 


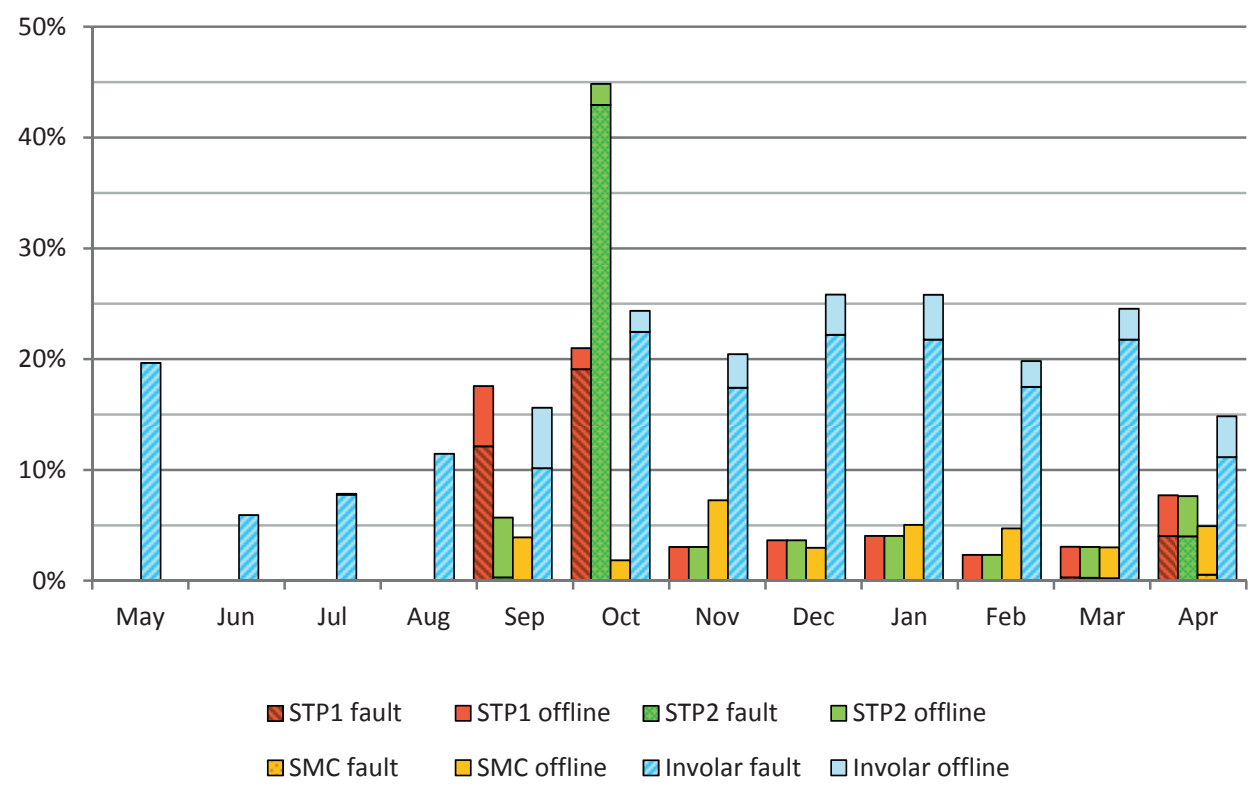

Fig. 5.12. Monthly fault and offline time. The fraction of the time (with $G_{b o r}>10 \mathrm{~W} / \mathrm{m}^{2}$ ) in which the PV system experiences faults per array per month from May 2013 - April 2014²1. Offline indicates the total number of hours per month that the PV system is disconnected from the grid.

The time in which the PV system is offline is based on the missing records of the SMA WebBox where the difference in electricity production between both records - from just before and just after the missing records - is significantly less compared with the electricity production during normal operation. The offline time of the Involar system cannot be determined as such, but is assumed to be equal to the maximum of both STP offline times.

As can be seen from the performance data in Appendix C.2, the STP1 PV array experiences faulty behavior from May 2014 and onwards. This is likely related to an inverter error; however the exact reason has not been determined yet.

In Fig. 5.13 the energy losses per PV array are shown for each month. The SMC array experiences few faults and its energy losses are mainly related to times when the PV system is offline due to grid instability or to the negative influence of the PV module temperature. Both STP arrays experienced faults in the months September and October. Faults in the Involar array occur every month, however the cause is unknown. Overall, most energy losses are caused by the losses related to the temperature, these account for $46 \%$. A smaller amount is caused by the PV system experiencing faults, this is $27 \%$. The other $28 \%$ is related to grid instability or power outages.

\footnotetext{
${ }^{21}$ For the month June data from the SMA Sunny WebBox are only available from the $19^{\text {th }}-30^{\text {th }}$ of June. For April, measurements from the data logger are only available from the $1^{\text {st }}-16^{\text {th }}$ of April.
} 


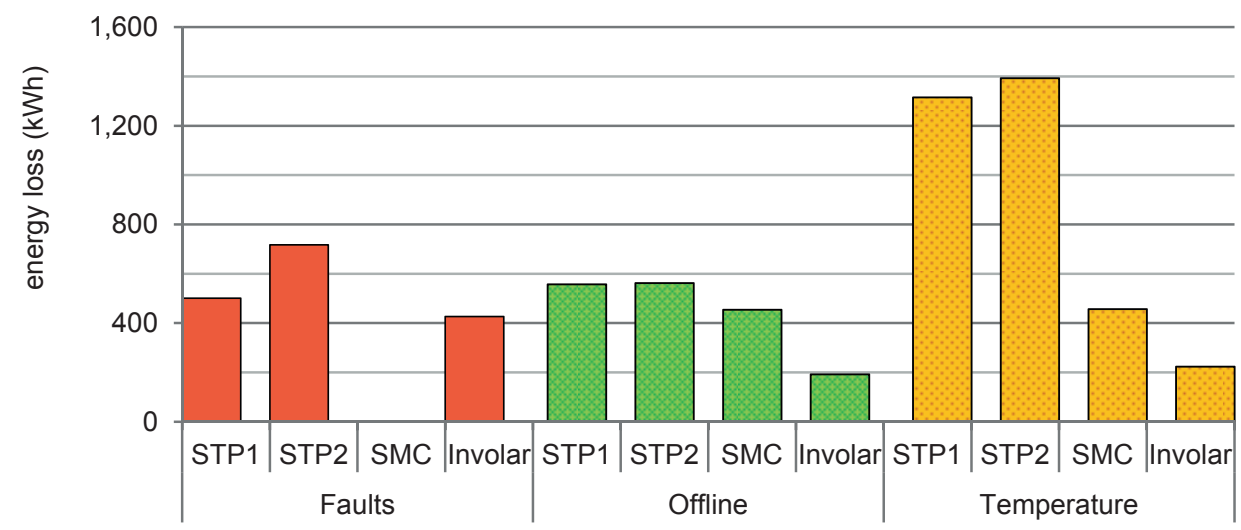

Fig. 5.13. Energy losses in kWh for each array of the PV system in Jayapura from May 2013 - April 2014.

To compare the energy losses of the different PV arrays, the total energy losses per installed capacity $\left(\mathrm{kWh} / \mathrm{kW}_{\mathrm{p}}\right)$ are shown in Fig. 5.14. The SMC array shows the lowest losses, it experiences few faults and the temperature losses are lower due to the lower temperature coefficient of the amorphous silicon modules.

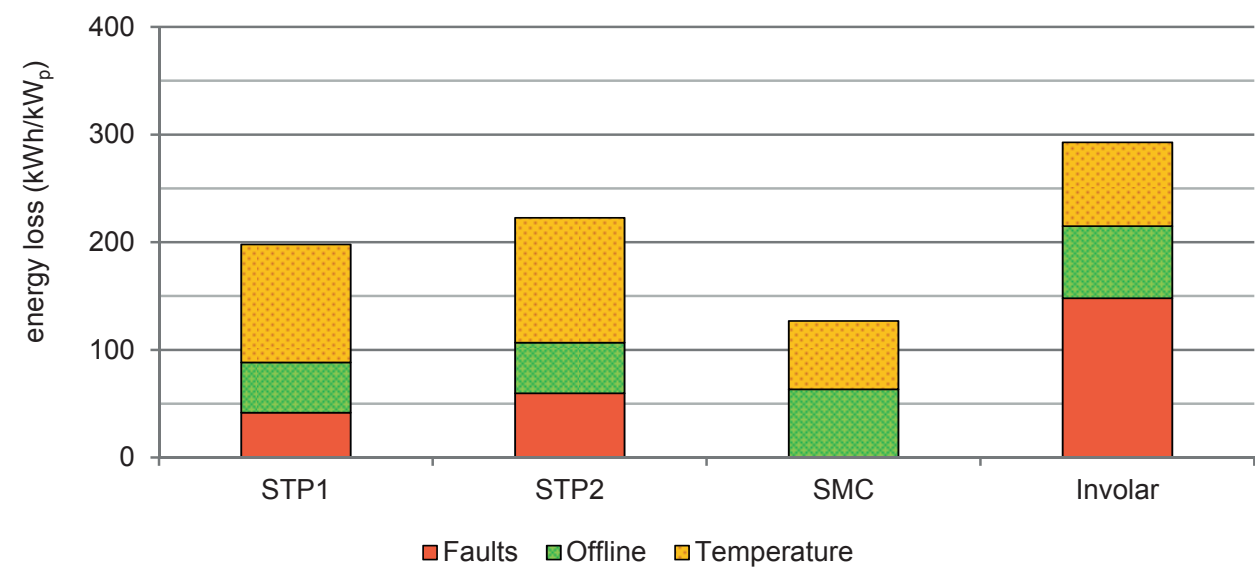

Fig. 5.14. Various energy losses in $\mathrm{kWh} / \mathrm{kW}$ per array of the PV system in Jayapura for the period May 2013 - April 2014.

To evaluate the performance of the PV system in Jayapura, it will be compared with the performances of other PV systems in Asia, like the ones evaluated by Nobre et al. [118]. They compared 11 PV systems in Singapore, the PRs of the various PV systems ranged from $82,6 \%$ to $58,1 \%$, based on measurements over the year 2011 . The median PR is $79.8 \%$, which is similar to the PRs of the STP PV arrays in Jayapura.

Compared with PRs from European systems presented in a study from Reich et al. [76], the PR of the SMC is among the best operating PV systems. 


\subsection{Comparison with expected energy yield}

The PV system has produced $83 \%$ of its projected energy yield of 51,800 kWh/year, however the actual PV system capacity is $34.08 \mathrm{~kW}_{\mathrm{p}}$ vs. $35 \mathrm{~kW}_{\mathrm{p}}$ assumed before. Besides, the actual irradiation during a year was estimated to $1,764 \mathrm{kWh} / \mathrm{m}^{2}$, which is lower than the $1,898 \mathrm{kWh} / \mathrm{m}^{2}$ assumed for the projected value. Taking this difference in nominal installed capacity and lower irradiation into account, then the projected energy yield would be $46,900 \mathrm{kWh} /$ year. This is $8 \%$ more than the final yield measured. Around $1 \%$ is due to the underperforming Involar system. The largest deviation is due to the offline time, which is excluded in the initial calculations. With a system availability factor of $93 \%$ on average, the related energy loss corresponds to about $4 \%$. The energy losses due to system faults represent roughly 3\%. If the PV system would have operated without these energy losses then the PV system has produced a total of $46,500 \mathrm{kWh}$, corresponding to $99 \%$ of the projected value.

\subsection{Conclusions}

When the PV system is online, it performs well with PRs around $80 \%$ for the STP arrays, about $90 \%$ for the SMC array and the Involar array performing significantly less, with an average PR of 57\%. Overall, the performances are in line with other PV systems in tropical areas.

The PV system is on average $2.4 \%$ of the time offline, with estimated energy losses of 1.8 $\mathrm{MWh}$, another 1.6 MWh is lost due to system faults and 3.4 MWh is lost due to the temperature effect. Relative to the 43.0 MWh of total electricity generated from May 2013 - April 2014, these losses are 4.1\%, 3.8\% and 7.9\%, respectively.

The total estimated energy losses are 6.8 MWh, which is $16 \%$ of the total electricity production during the investigated period. 


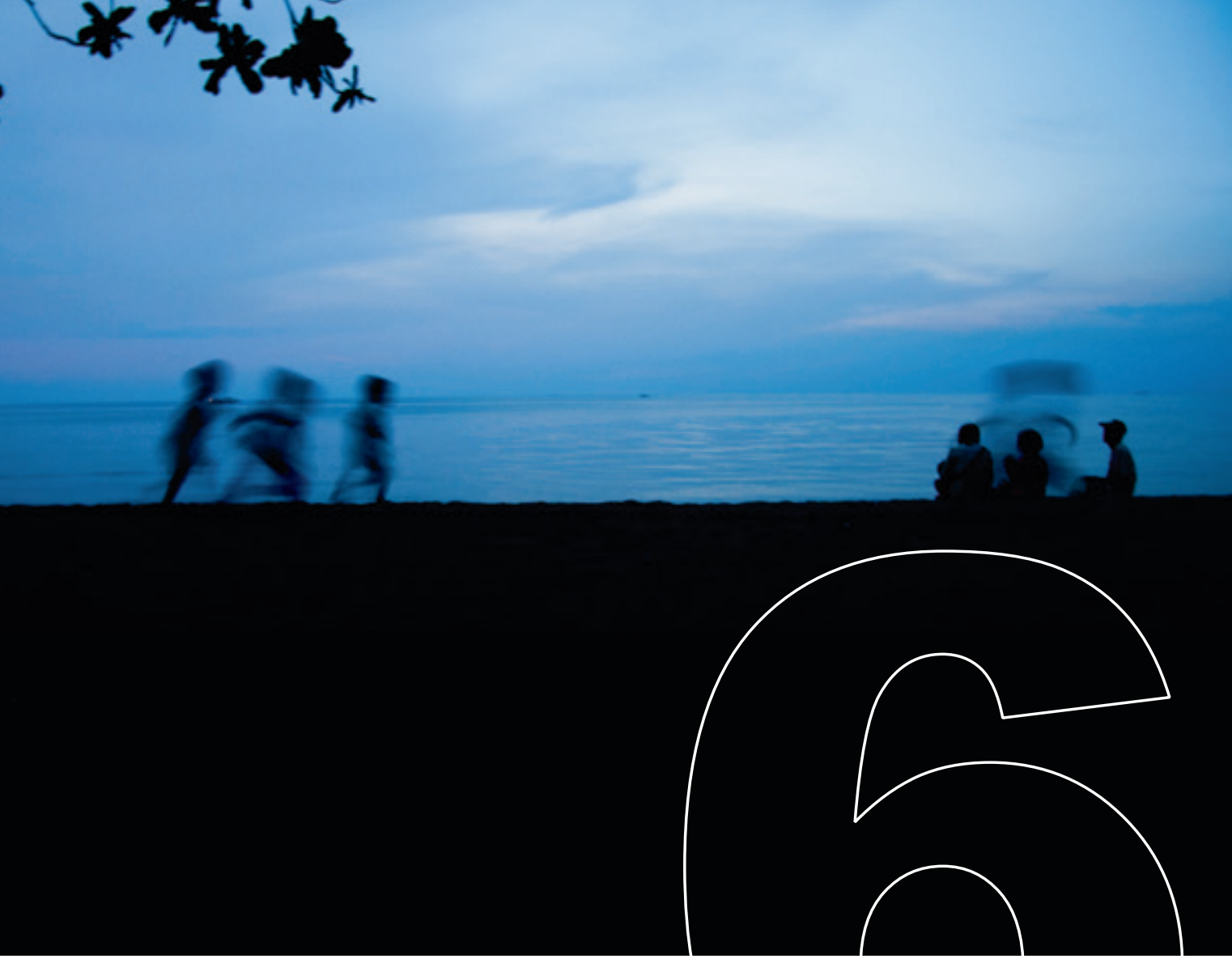

\section{Simulating the PV power}

generation in a virtual

environment

Parts of this Chapter have been published in the Proceedings of the 29th European Photovoltaic Solar Energy Conference and Exhibition, Amsterdam, 2014. A.J. Veldhuis and A.H.M.E. Reinders, Simulation of Power Produced by a Building Added PV System in Indonesia using Virtual Reality, pp. 2604-2608. 


\section{6}

\section{Simulating the PV power generation in a virtual environment}

In this chapter the PV system in Jayapura will be simulated in order to study the appropriateness of the applied simulation models for tropical locations, such as Jayapura.

\subsection{Introduction}

As described in section 2.5, simulations of the power output of PV systems can be used for various purposes, depending on the product phase: During design and operation. During the PV system design phase, simulations can be valuable for PV system designers in order to:

- Find the optimal position of PV modules, by taking local shading conditions into account. The position can be optimized for energy yield, but other aspects such as appearance and accessibility can assessed as well.

- Estimate the energy yield during its projected lifetime in order to evaluate the financial feasibility of the project.

- Assist discussions with various stakeholders of the PV system.

During the operational phase, simulations can help to:

- Detect PV system faults.

- Forecast the power output of grid-connected PV systems.

Various simulation software exist already for different purposes, such as RADIANCE [119], PVsyst [120], Homer Energy [121] and SketchUp [122]. However, it was found that existing simulation tools lacked the flexibility and ease of use to simulate PV power for complex scenarios, which arise in the built environment and with PV products. For this reason the software tool VR4PV has been developed in 2011 [123]. It is a virtual reality (VR) software environment in which the power output of PV systems can be simulated. By simulating the power output of PV cells in this $3 \mathrm{D}$ software environment, the modeling takes the shadows created by objects in the vicinity of the actual PV system into account, 
visually showing their effects, namely the shadow casted on the PV cells, as well as calculating the reduction of power produced due to the shades. During the simulation it is possible to view the environment from various positions and directions, while the sun's position changes over time causing moving shadows. A detailed description and validation of the VR4PV can be found in Appendix D.

In this chapter the VR4PV will be applied to simulate the power output of the PV system in Jayapura which is described in chapter 5.

In Fig. 6.1 a 3D render of the district office in the VR4PV software tool is shown.

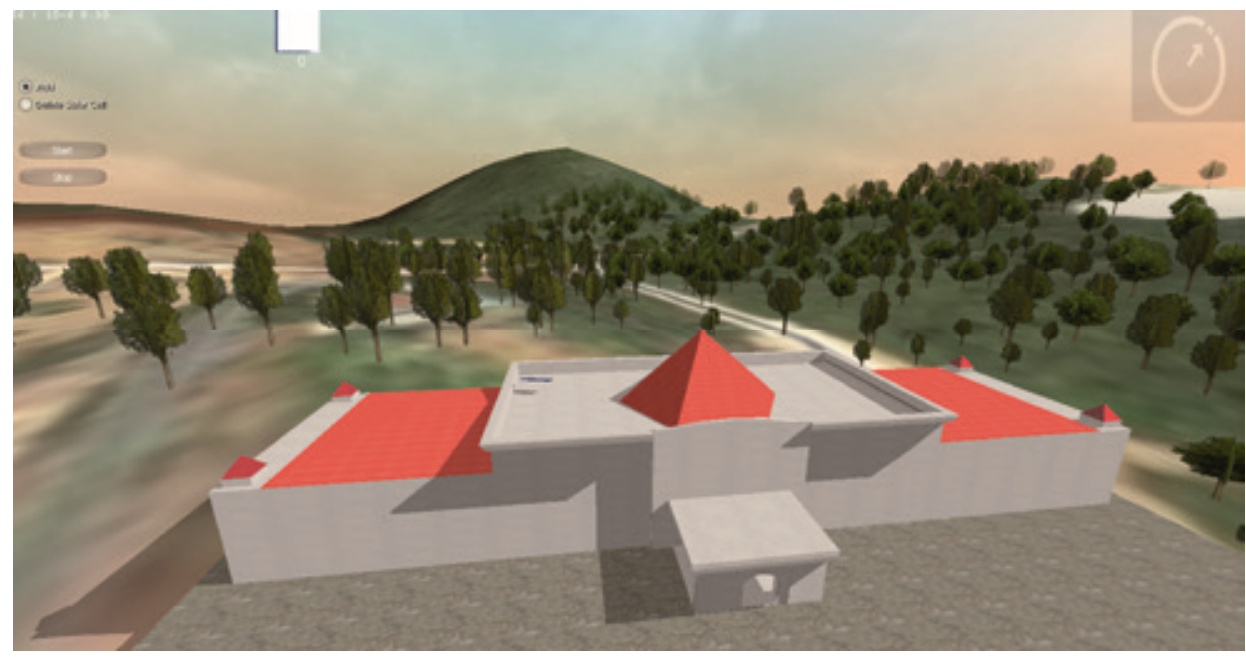

Fig. 6.1. A 3D render of the district office in the VR4PV software tool.

\subsubsection{Research questions}

The main research question in this chapter is: How well do PV power output simulations, based on existing models evaluated for Western climates, perform in Indonesia by applying locally and publicly available weather data?

This can be divided into two sub questions:

- How do PV power output simulations, based on existing irradiance and temperature models evaluated for Western climates as applied in the VR4PV, perform in Indonesia compared with Western PV systems?

- How accurately can the PV power output be simulated by publicly available weather data?

\subsubsection{Outline}

In the next section the methodology will be described, it will start with a short description of the simulation procedure in VR4PV followed by a description of the input 
data. In the subsequent section the results are presented. The chapter will finish with a discussion and conclusions.

\subsection{Simulation approach and input data}

To answer the research question, the power output of the PV system is simulated based on (i) minutely locally measured weather data, and (ii) hourly publicly available weather data. The results are compared with the measured power output in order to (i) evaluate the performance of the VR4PV for this location, and (ii) evaluate the use of publicly available weather data to determine the power output of the PV system.

The VR4PV software will be used for simulations of the power output of one of the 12 $\mathrm{kW}_{\mathrm{p}}$ PV arrays (STP1 as described earlier in section 5.2.2) at the roof of the district office in Jayapura.

\subsubsection{Simulation procedure}

The VR4PV tool determines the power output of PV cells based on three weather input variables: global horizontal irradiance, ambient temperature and wind speed. Time series of these weather data can be imported into the VR4PV.

The simulation procedure of the VR4PV is shown in Fig. 6.2 and a detailed description can be found in Appendix D.2. For every time step the irradiance received by each simulated PV cell will be calculated, taking the orientation and tilt angle into account. To achieve this, the global horizontal irradiance is translated to tilted irradiance by using the Liu and Jordan model [81], which is a simple isotropic sky model. The model consists of three components: direct, diffuse and ground-reflected irradiance. For the estimation of the diffuse part of the irradiance the Orgill and Hollands relationship [124] is included.

For the determination of the PV cell temperature the model of Skoplaki et al. [125] is applied. This is an empirical model which calculates the PV cell temperature based on the irradiance, ambient temperature and wind speed.

Shadows from surrounding objects can be included as well, which will affect the direct component of the irradiance received by the PV cell.

The simulated power output of the PV cell is based on the mono-crystalline PV modules used in the PV system in Jayapura; its parameters are shown in Appendix B.1. The electrical PV module model is based on the model of D. Sera et al. [85].

The simulated power output is compared with the measured power output $P_{d c}$ based on the DC current $I_{d c}$ and voltage $V_{d c}$ measurements of the STP1 PV array. It is assumed that the unmeasured DC power of the third PV string will be identical to the measured one; both PV strings consist of twenty PV modules. 


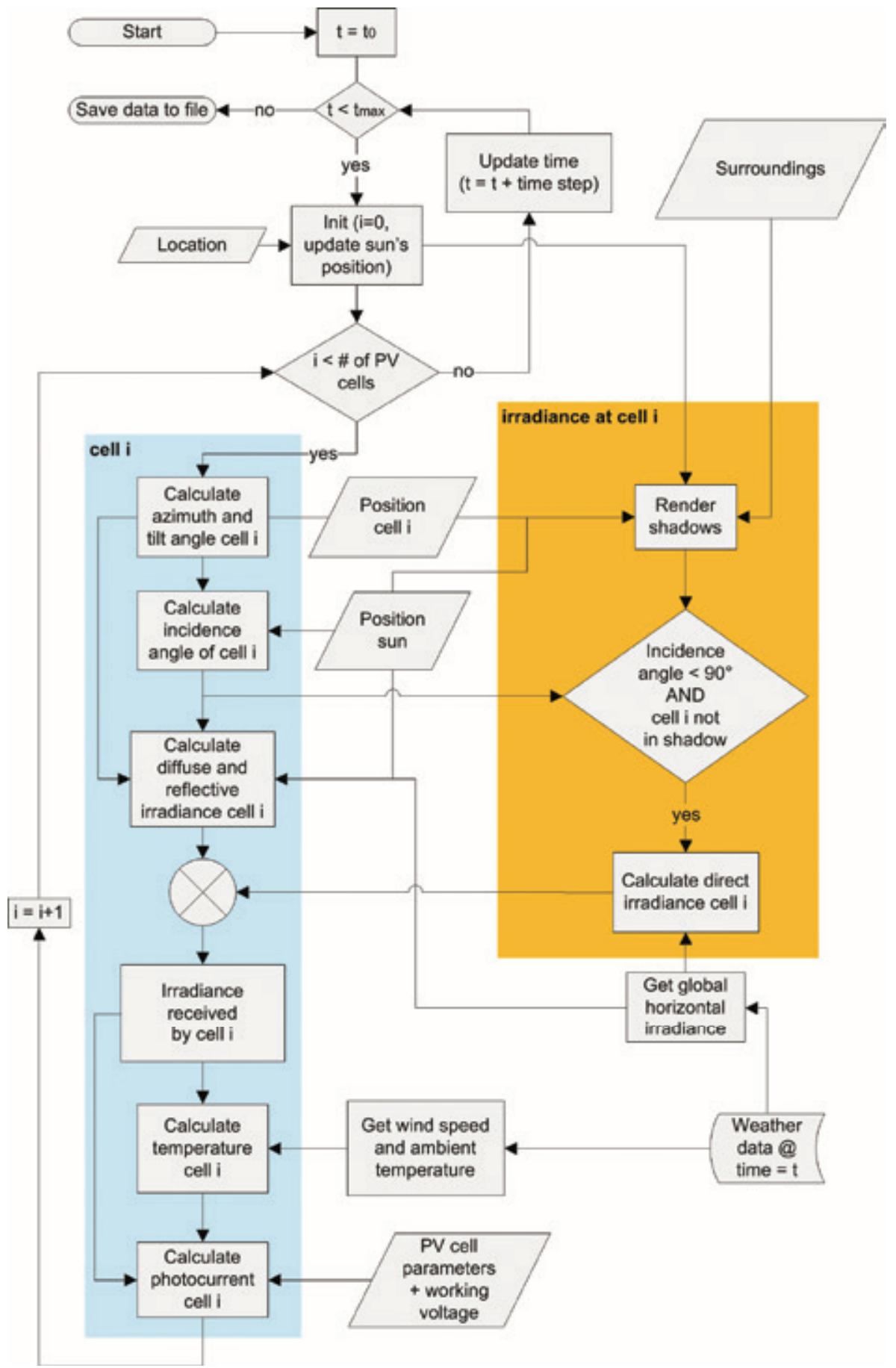

Fig. 6.2. Flowchart of the simulation procedure in VR4PV [123] 
The DC power is calculated as follows:

$P_{d c}=2 \times I_{d c-x, 1} \times V_{d c-x, 1}+I_{d c-x, 2} \times V_{d c-x, 2}$

\subsubsection{Input data}

For the minutely simulation of the power output of the PV system in Jayapura, the locally minutely measured global horizontal irradiance, ambient temperature and wind speed on site is applied. For the hourly simulation meteorological data from some nearest climatological stations are used as input.

A weather station of the Atmospheric Radiation Measurement (ARM) Climate Research Facility is located at Manus, Papua New Guinea (2 $3^{\prime}$ 'S, $\left.147^{\circ} 25^{\prime} \mathrm{E}\right)$. Besides, data from two moored ocean buoys of the Tropical Atmosphere Ocean (TAO) project of the National Oceanic and Atmosphere Administration (NOAA) agency are used. One is positioned at $2^{\circ} \mathrm{N}, 137^{\circ} \mathrm{E}$ and the other is situated at $0^{\circ} \mathrm{S}, 147^{\circ} \mathrm{E}$, the locations are shown in Fig. 6.3. Since climatological stations are sparse in this area of the world, the locations of the stations are relatively far away from the PV system, the distances vary roughly between 650 and 900 $\mathrm{km}$.

The global horizontal irradiance $\left(\mathrm{W} / \mathrm{m}^{2}\right)$ is measured at all locations. For the TAO sites, hourly averages are available. Minutely averages are obtained from the ARM site and these are converted to hourly averages as well.

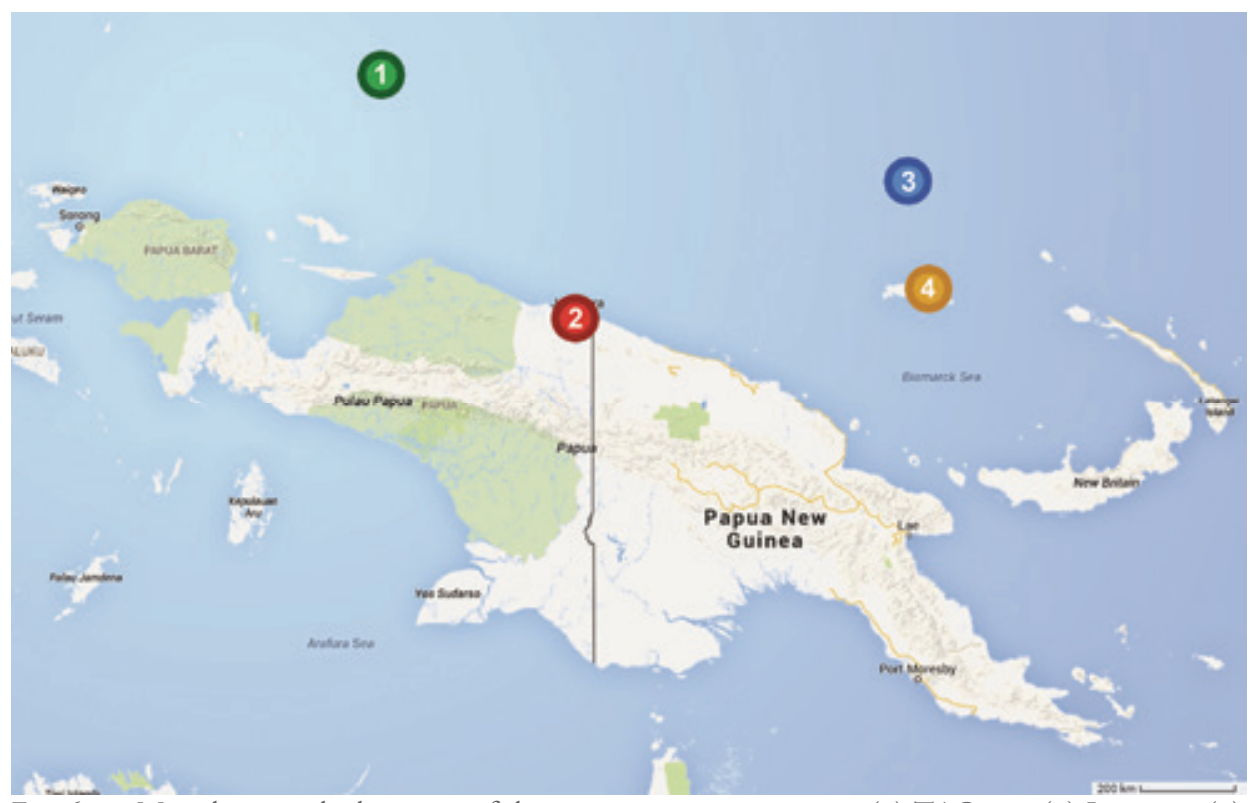

Fig. 6.3. Map showing the locations of the various monitoring sites - (1) TAO137, (2) Jayapura, (3) TAO147 and (4) ARM site. Map data (C) 2014 GBRMPA, Google. 
As input for the simulation the hourly averaged irradiances from the ARM and TAO137 sites are interpolated for the longitude in Jayapura. Although all datasets are nearly complete, some records are missing, in particular in the datasets from the TAO project. If the hourly record from the TAO137 site is missing, then the average of the irradiances measured at the TAO147 and the ARM site is used instead of the interpolation. When the TAO147 record is missing as well, the irradiance measured at the ARM site is used.

The ambient temperature used as input is based on the hourly averaged ambient temperature at the ARM site.

For this study data from May 2013 - April 2014 are used.

\subsubsection{PV module characteristics}

The power output is based on the maximum power point. For this purpose the I-V curve of the CEEG PV module has been modeled based on the datasheet values by the model of Sera et al. [85], which applies an one-diode-model.

In Jayapura the 240-60M PV modules have been installed; however, the datasheet of the supplier shows only the I-V and P-V curves of another PV module from the same series, namely the 260-60M PV module [126]. The 260-60M PV module has a peak power of $260 \mathrm{~W}$, according to the specifications; however the P-V curve, as shown in Fig. 6.4, shows a maximum power of roughly $240 \mathrm{~W}$. For this reason, the method to determine the PV cell characteristics based on the specifications only, would not result in the right electrical PV model; however, to show the difference in power output these results are included in Fig. 6.4 as well. The grey lines correspond to the results obtained by the model of Sera et al. [85] based on a maximum power of $260 \mathrm{~W}$ for an irradiance level of $1,000 \mathrm{~W} / \mathrm{m}^{2}$.

To model the PV module correctly, the PV cell characteristics have been modified in such a way that the modeled I-V curve is approximately the same as the supplied I-V curve. A combination of a series resistance of $0.34 \Omega$, a shunt resistance of $200 \Omega$ and a diode ideality factor of 1.4 has been found to correspond well to the I-V curve. The I-V curves for various irradiance levels and PV module temperatures have been determined. In Fig. 6.4 and in Fig. 6.5 the model results are shown as an overlay on the I-V and P-V curves of the supplier, the dashed I-V curves and the solid P-V curves are based on the model. As can be seen, the modeled curves correspond well to the I-V and P-V curves as presented in the datasheet of the supplier of the PV modules. 


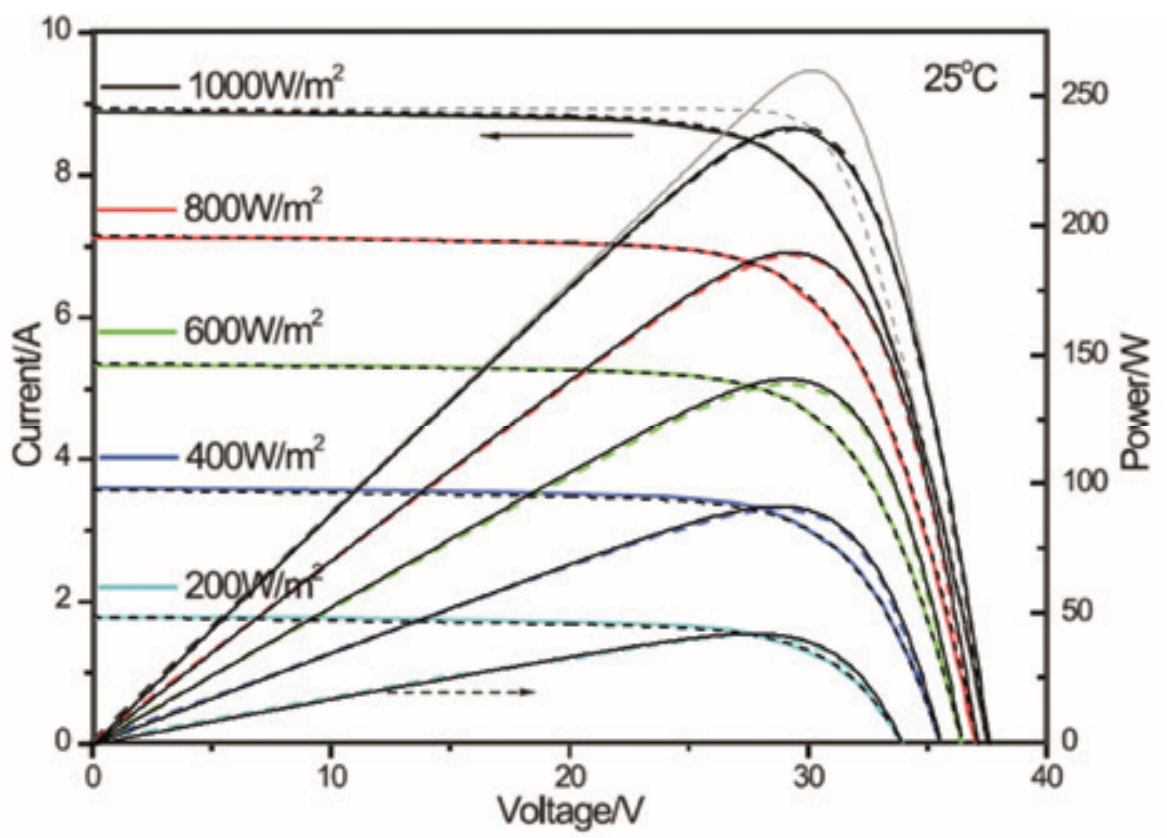

Fig. 6.4. I-V and P-V curves of the 260-60M CEEG PV module at different irradiance levels at a PV module temperature of $25^{\circ} \mathrm{C}$. The colored lines correspond to the curves of the supplier; the black lines correspond to the modeled curves as applied in this study. The grey lines correspond to the curves if the PV module would have had a peak power of $260 \mathrm{~W}$, as specified.

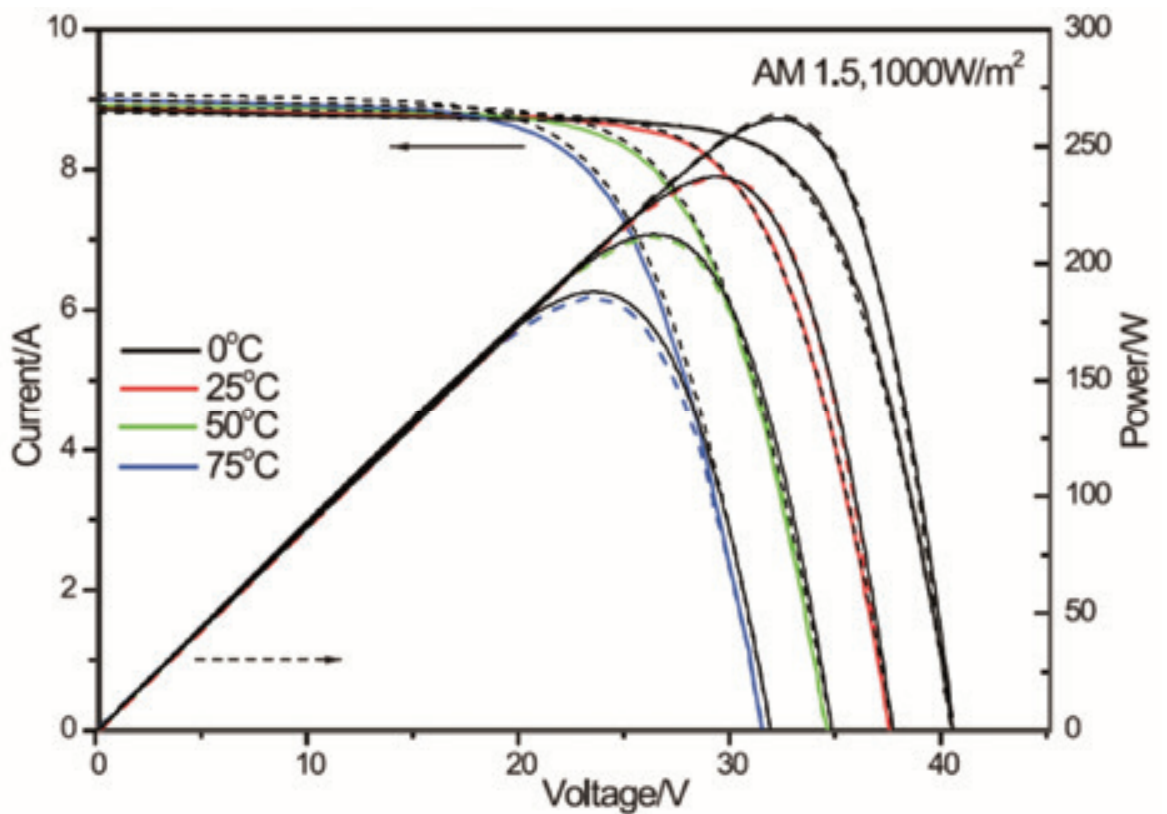

Fig. 6.5. I-V and P-V curves of the 260-60M CEEG PV module at PV module temperatures at an irradiance of $1,000 \mathrm{~W} / \mathrm{m}^{2}$. The colored lines correspond to the curves of the supplier; the black lines correspond to the modeled curves as applied in this study. 


\subsection{Simulation results}

\subsubsection{Minutely simulation}

In Fig. 6.6 the minutely measured vs. simulated DC power output of the $12 \mathrm{~kW}_{\mathrm{p}} \mathrm{PV}$ array is shown for the month May 2013. From the figure can be observed that in general the simulated power output corresponds well with the measured power output; a slight overestimation is visible at higher power levels.

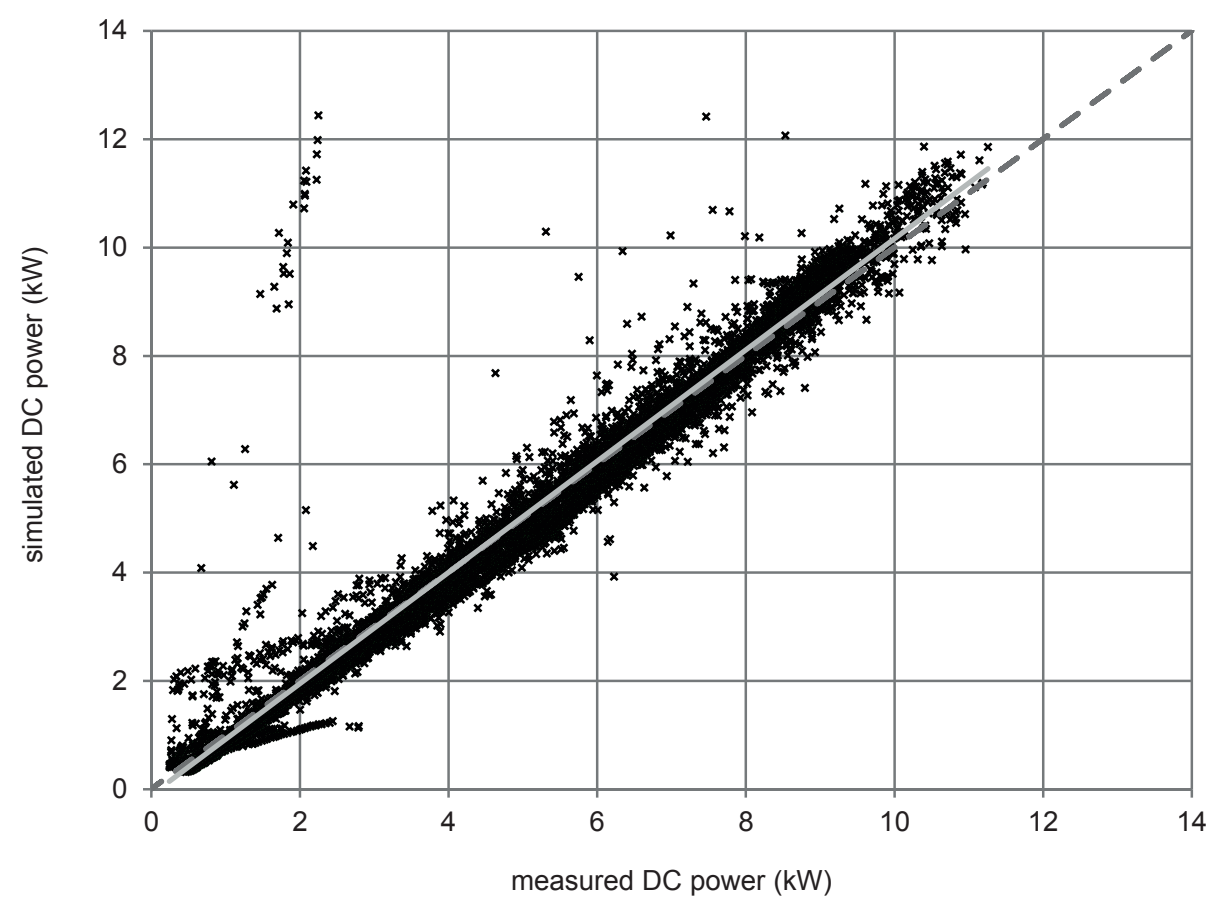

Fig. 6.6. Measured versus simulated minutely DC power output (kW) of the $12 \mathrm{~kW}$ PV array of the PV system in Jayapura for May 2013 for irradiance levels exceeding $50 \mathrm{~W} / \mathrm{m}^{2}$. The solid line is the linear regression, the dashed line $\mathrm{x}=\mathrm{y}$ is a guide for the eye.

In Fig. 6.7 to Fig. 6.10 time series of the simulated vs. measured DC power, DC voltage, DC current and PV module temperature are shown for the $4^{\text {th }}$ and $5^{\text {th }}$ of May 2013. The simulated values correspond well to the measured ones; however, the simulated DC voltage shows a significant deviation from the measured values, especially during sunset and sunrise time and around noon. At the begin and end of the day, the simulated voltage is lower than measured. Around noon the simulated voltage is higher than measured. 


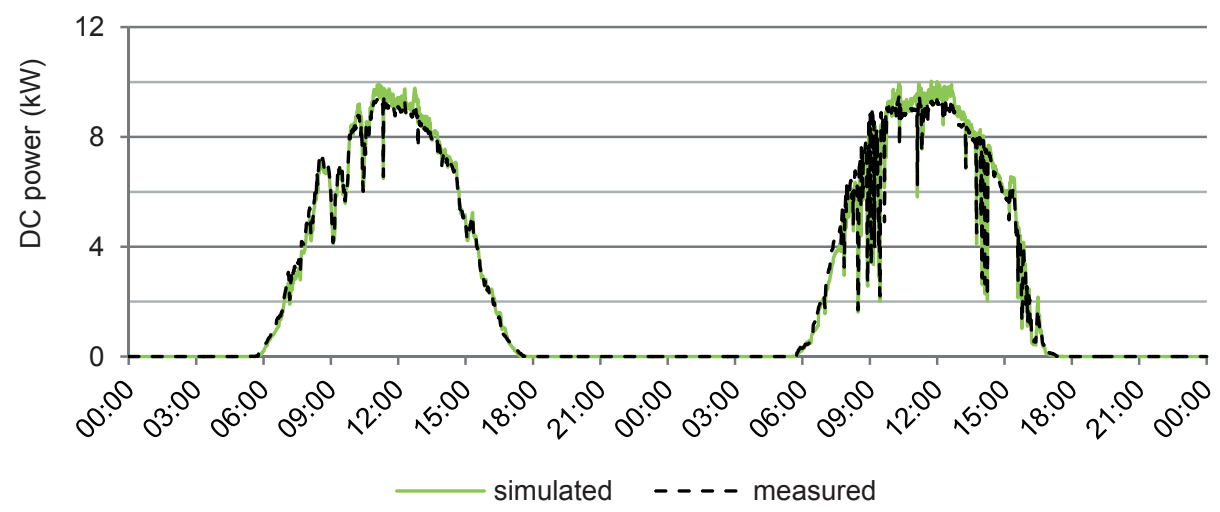

Fig. 6.7. Measured vs. simulated DC power $(\mathrm{kW})$ of the STP1 PV array during the $4^{\text {th }}$ and $5^{\text {th }}$ of May 2013.

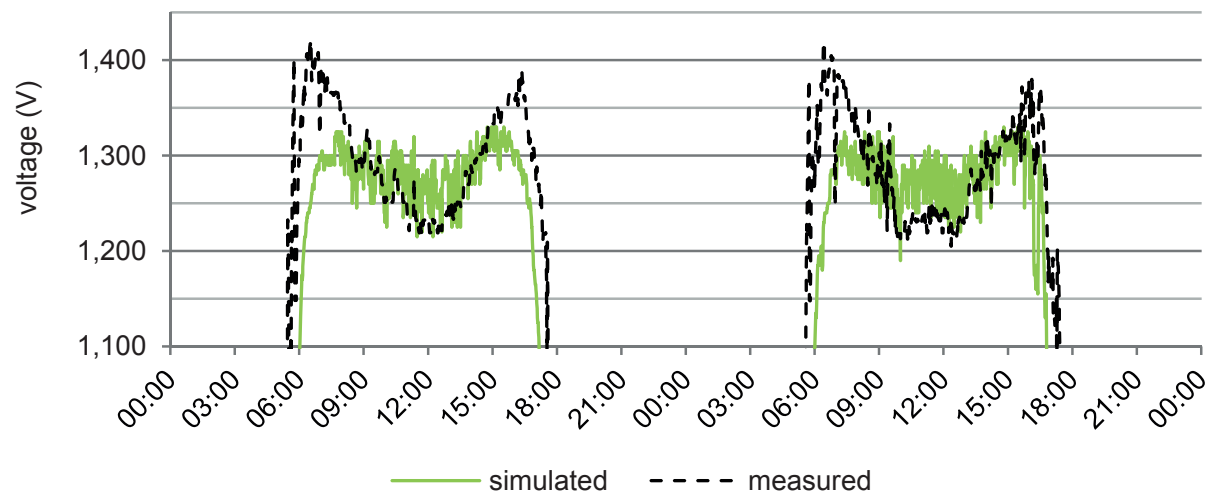

Fig. 6.8. Measured vs. simulated voltage (V) of the STP1 PV array during the $4^{\text {th }}$ and $5^{\text {th }}$ of May 2013.

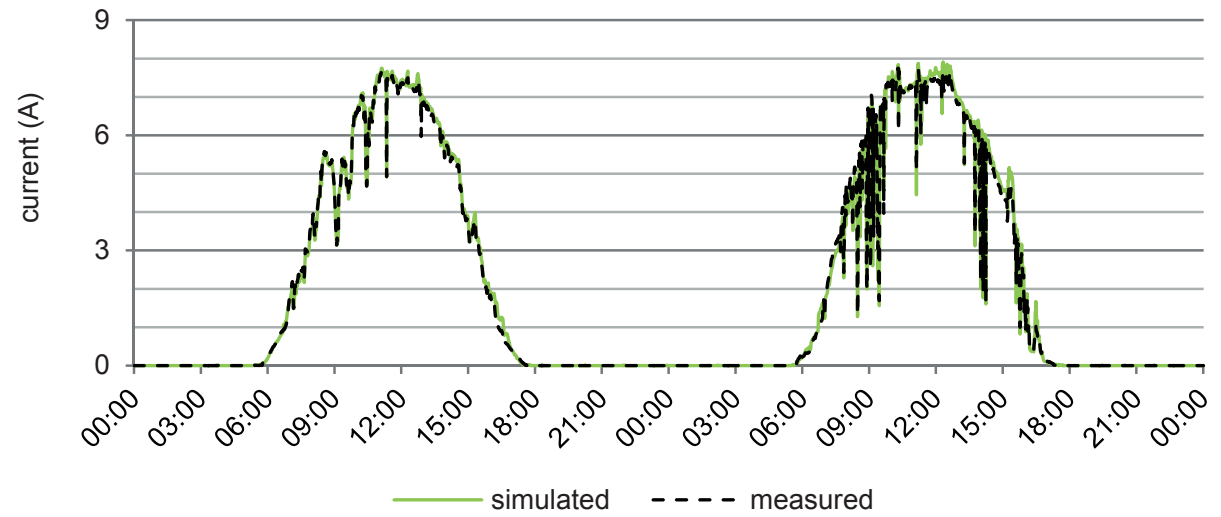

Fig. 6.9. Measured vs. simulated current (A) of the STP1 PV array during the $4^{\text {th }}$ and $5^{\text {th }}$ of May 2013. 


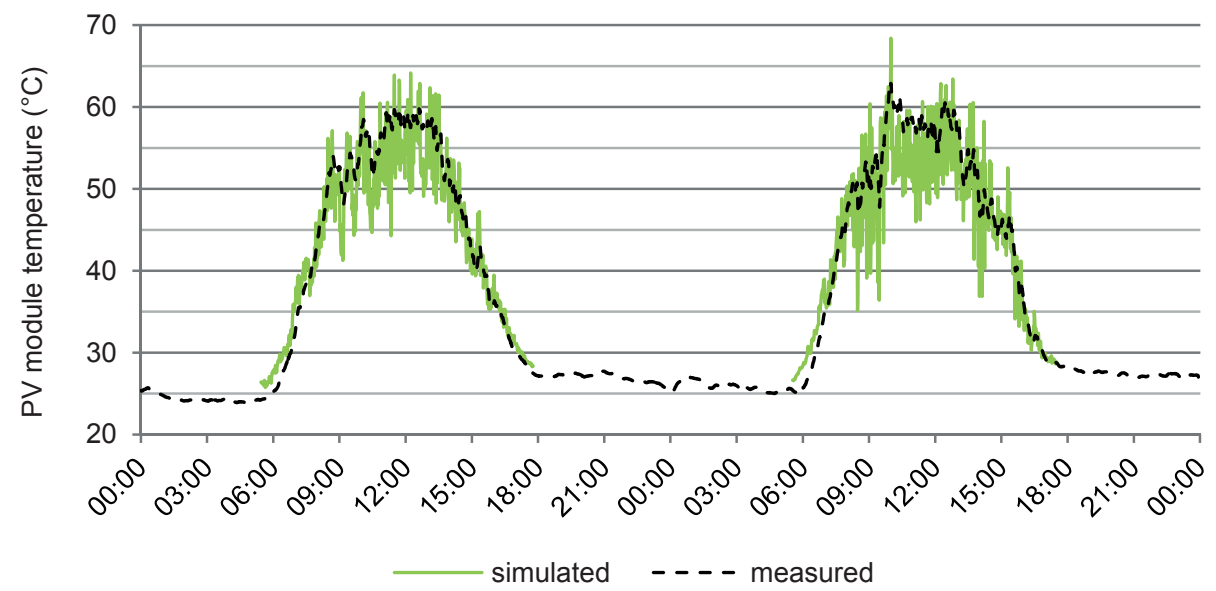

Fig. 6.10. Measured vs. simulated PV module temperature during the $4^{\text {th }}$ and $5^{\text {th }}$ of May 2013. Simulated values are shown for irradiance levels exceeding $1 \mathrm{~W} / \mathrm{m}^{2}$.

In Fig. 6.10, the time series of the PV module temperature is shown. As can be seen, the simulated temperature follows the right trend; however, large errors of more than $10{ }^{\circ} \mathrm{C}$ exist. Since the PV module temperature is related to the operating voltage of the PV module, the deviation found in the DC voltage could be related to this mismatch in PV module temperature.

To calculate the root-mean-square error (RMSE) of the simulated DC power, only minutely records with horizontal irradiance values exceeding $50 \mathrm{~W} / \mathrm{m}^{2}$ are taken into account, because lower irradiance levels are prone to errors. Besides, some records with measurement errors are excluded from the RMSE calculation. The RMSE of the minutely simulated DC power output for the $12 \mathrm{~kW}_{\mathrm{p}}$ PV array is shown in Table 6-1 for each month. Also, the RMSE relative to the average DC power output (for $G>50 \mathrm{~W} / \mathrm{m}^{2}$ ) is shown, varying from $7-18 \%$.

From May - September 2013 both the RMSE as the relative error are low, ranging from $7-9 \%$ and $-2-3 \%$, respectively. The months October to December 2013 show a larger deviation, with values between $7-9 \%$ for the relative error of the electricity production. This influences the RMSE of the simulated power as well, which are significant higher with values between 13-18\% for the relative RMSE. The exact reason for this is hard to determine. It could be that the PV modules are not operating at their maximum power point or that the modeled maximum power point is too high.

Overall, the electricity production is simulated well; there is a slight overestimation of $3 \%$ on average. 
TABLE 6-1: RMSE OF THE MINUTELY SIMULATED DC POWER OUTPUT

\begin{tabular}{lrrrrrr}
\hline Month & $\begin{array}{r}\text { avg } P_{\text {meas }}{ }^{*} \\
(\mathrm{~W})\end{array}$ & $\begin{array}{r}\text { RMSE } \text { sim }^{*} \\
(\mathrm{~W})\end{array}$ & $\begin{array}{r}\text { RMSE } \text { sim }^{* *} \\
(\%)\end{array}$ & $\begin{array}{r}\mathrm{E}_{\text {meas }} \\
(\mathrm{kWh})\end{array}$ & $\begin{array}{r}\mathrm{E}_{\text {sim }} \\
(\mathrm{kWh})\end{array}$ & $\begin{array}{r}\text { rel. err. } \mathrm{E}_{\text {sim }} \\
(\%)\end{array}$ \\
\hline May & 4,943 & 467 & 9 & 1,524 & 1,524 & 0.0 \\
\hline Jun & 4,596 & 380 & 8 & 1,333 & 1,308 & -1.9 \\
\hline Jul & 4,340 & 392 & 9 & 1,341 & 1,322 & -1.5 \\
\hline Aug & 4,830 & 349 & 7 & 1,571 & 1,587 & 1.0 \\
\hline Sep & 4,901 & 449 & 9 & 1,228 & 1,268 & 3.1 \\
\hline Oct & 4,175 & 739 & 18 & 1,032 & 1,136 & 9.2 \\
\hline Nov & 4,249 & 558 & 13 & 1,226 & 1,318 & 6.9 \\
\hline Dec & 3,929 & 666 & 17 & 1,009 & 1,095 & 7.8 \\
\hline Jan & 3,633 & 520 & 14 & 1,123 & 1,165 & 3.6 \\
\hline Feb & 4,440 & 570 & 13 & 927 & 970 & 4.4 \\
\hline Mar & 4,199 & 644 & 15 & 1,345 & 1,413 & 4.9 \\
\hline Apr & 4,066 & 469 & 12 & 1,167 & 1,163 & -0.3 \\
\hline Average & 4,358 & 517 & 12 & 1,236 & 1,272 & 3.1 \\
\hline
\end{tabular}

The average $P_{\text {meas }}$ and the RMSE $P_{\text {sim }}$ are based on irradiance levels $G_{\text {hor }}>50 \mathrm{~W} / \mathrm{m}^{2}$

** The relative RMSE $\mathrm{P}_{\text {sim }}$ is relative to avg $\mathrm{P}_{\text {meas }}$

In Fig. 6.11 the relative error of the simulated tilted irradiance is shown for bins of 50 $\mathrm{W} / \mathrm{m}^{2}$ in the horizontal irradiance range of $50-1,200 \mathrm{~W} / \mathrm{m}^{2}$ for the months January to March 2014. As can be seen, the simulated irradiance is slightly overestimated in general. The relative error is larger at lower irradiance levels: the error decreases from $14 \%$ in between $50-100 \mathrm{~W} / \mathrm{m}^{2}$ to $4 \%$ in the irradiance range of $1,150-1,200 \mathrm{~W} / \mathrm{m}^{2}$.

A similar study to evaluate the performance of the VR4PV to determine the tilted irradiance based on minutely global horizontal irradiance is carried out for a location in Italy. Details about this study can be found in Appendix D.3. The results (see Appendix D.4) show an average relative error of $-3 \%$ for irradiance levels between 300 and 1,050 $\mathrm{W} / \mathrm{m}^{2}$ for a tilt angle of $30^{\circ}$. The average RMSE for this range is found to be $29 \mathrm{~W} / \mathrm{m}^{2}$. Compared with the results obtained for Jayapura, with an average relative error of $5 \%$ and an average RMSE of $40 \mathrm{~W} / \mathrm{m}^{2}$ for the same irradiance range, the irradiance models implemented in the VR4PV are found to perform comparable at both locations. Besides, the accuracy of the simulated tilted irradiance is similar to the accuracy of the in-plane silicon reference cell of 5\%, as described earlier in section 5.2.2. 


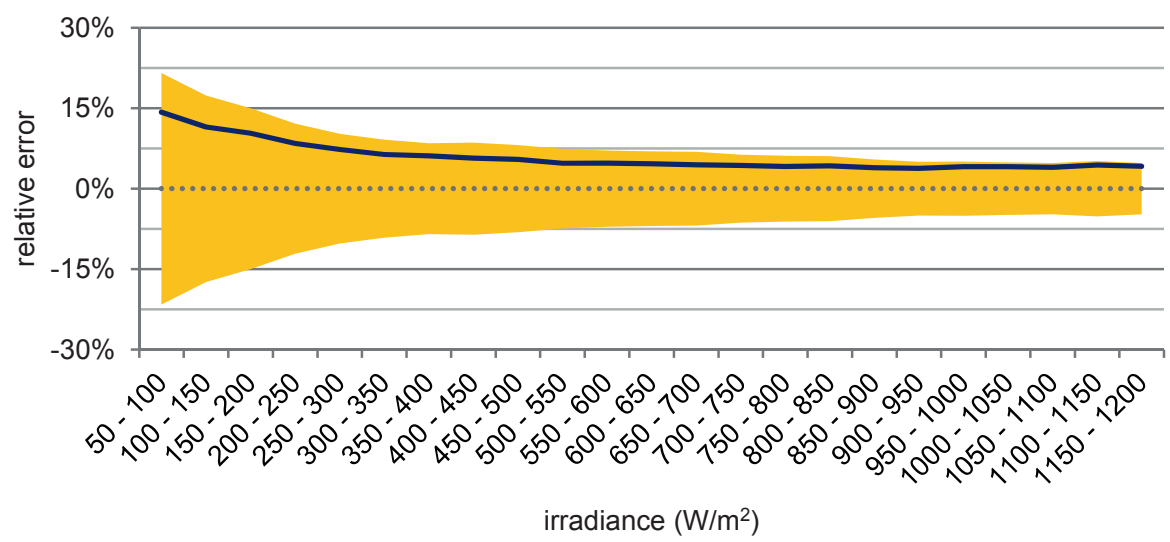

RMSE range $\longrightarrow$ relative error $\quad \cdots . . . .$. zero

Fig. 6.11. Relative error of the simulated tilted irradiance per irradiance range of $50 \mathrm{~W} / \mathrm{m}^{2}$ in the range of $50-1,200 \mathrm{~W} / \mathrm{m}^{2}$ for the period January 2014 - March 2014.

In Fig. 6.12 a similar graph as in Fig. 6.11 is shown for the PV module temperature, it shows the relative error per irradiance bin of $50 \mathrm{~W} / \mathrm{m} 2$ for the horizontal irradiance range of $50-1,200 \mathrm{~W} / \mathrm{m}^{2}$ for the months May 2013 - April 2014. As can be seen, in general the simulated PV module temperature corresponds well to the measured PV module temperature. For low and high irradiance levels the temperature is overestimated. The RMSE is around $10 \%$ of the average PV module temperature measured at the specific irradiance levels.

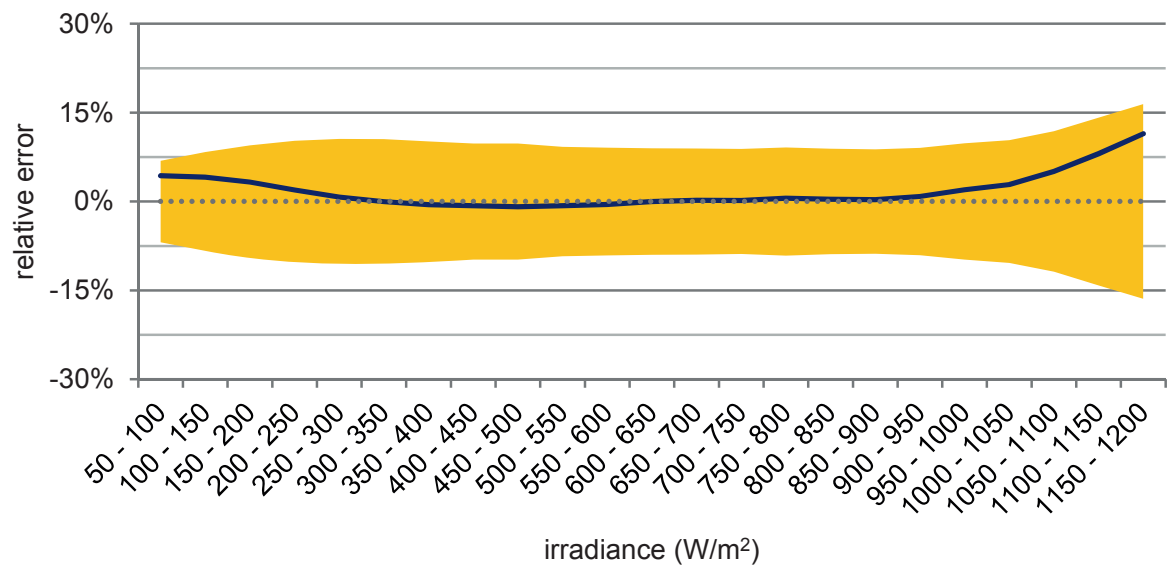

RMSE range relative error zero

Fig. 6.12. Relative error of the simulated PV module temperature per irradiance range of $50 \mathrm{~W} / \mathrm{m}^{2}$ for irradiances from $50-1,200 \mathrm{~W} / \mathrm{m}^{2}$ for the period May 2013 - April 2014. 
In Fig. 6.13 the relative error of the simulated DC power is shown for irradiance bins of $50 \mathrm{~W} / \mathrm{m}^{2}$. The relative error is based on the ratio of the average simulated to the average measured DC power per bin. Besides, the RMSE is determined for each irradiance bin, subsequently the relative RMSE is determined by dividing the RMSE by the average measured DC power corresponding to the same bin. The relative RMSE range is included in Fig. 6.13 as well.

From the figure, it follows that the relative error slightly increases from $-11 \%$ in the lowest irradiance bin to $+12 \%$ in the highest irradiance bin. For irradiance levels in the range of $50-200 \mathrm{~W} / \mathrm{m}^{2}$ - corresponding to $6 \%$ of the total electricity production - the average relative error is $-4 \%$. For irradiance levels ranging from $200-1,200 \mathrm{~W} / \mathrm{m}^{2}-$ corresponding to $93 \%$ of the total electricity production - the average relative error is $+4 \%$, as can be seen.

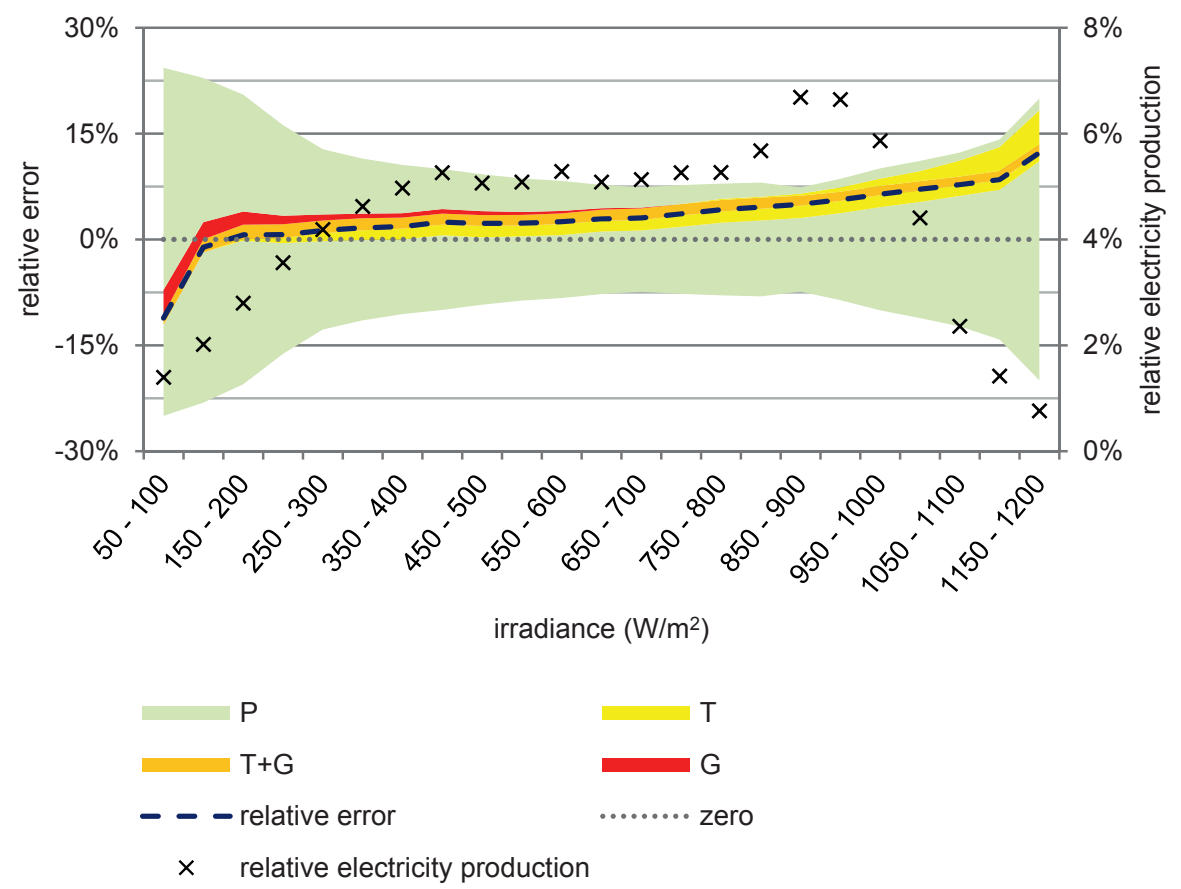

Fig. 6.13. Relative error of the DC power per irradiance range of $50 \mathrm{~W} / \mathrm{m}^{2}$ for irradiances from 200 $1,200 \mathrm{~W} / \mathrm{m}^{2}$ for the period May 2013 - April 2014. The error related to the inaccuracy of the temperature model is shown as well. Also the percentage of the total electricity production per bin is shown.

To show the influence of the RMSE of the simulated temperature on the RMSE of the simulated power, the RMSE of the temperature obtained for each irradiance bin is translated to the RMSE of the power. This is achieved by multiplying the RMSE of the PV module temperature by the temperature coefficient for the maximum power $\left(-0.42 \% /{ }^{\circ} \mathrm{C}\right)$. 
Subsequently, the relative RMSE has been obtained by dividing this RMSE by the average measured DC power of the particular bin. This relative RMSE range, in between the positive and negative RMSE values of the PV module temperature, has been included in Fig. 6.13. It shows the relative error and RMSE ranges for the irradiance range of $200-$ $1,200 \mathrm{~W} / \mathrm{m}^{2}$. Based on the relative error of the PV module temperature per bin, the RMSE range has been shifted vertically along the overall relative error of the simulated power.

The same procedure has been carried out for the RMSE of the irradiance $(\mathrm{G})$, which has been converted to a RMSE of the power by multiplying the RMSE by the average DC efficiency of $13 \%$, as discussed in the previous chapter.

In Fig. 6.13, both the RMSE range of the PV module temperature (T) and the irradiance $(\mathrm{G})$ are shown, the overlapping range $(\mathrm{T}+\mathrm{G})$ is shown as well.

The RMSE of the PV module temperature causes a relative error on the power output of $2 \%$ for the irradiance range from $200-1,200 \mathrm{~W} / \mathrm{m}^{2}$. The RMSE found for the simulated PV module temperature is influenced by the accuracy of the simulated irradiance as well. Based on the implemented temperature model of Skoplaki et al. and assuming a wind speed of $1 \mathrm{~m} / \mathrm{s}$ and a mounting coefficient of 1 , this accounts for 0.4 percentage point for the same irradiance range.

The relative RMSE of the PV module temperature increases with increasing irradiance, for the irradiance range of $200-1,200 \mathrm{~W} / \mathrm{m}^{2}$ the RMSE increases from $3.6^{\circ} \mathrm{C}$ to $9.4{ }^{\circ} \mathrm{C}$ corresponding to $10 \%$ and $16 \%$ of the average PV module temperature measured per irradiance bin.

\subsubsection{Hourly simulation}

In Fig. 6.14 the average daily irradiation per month for Jayapura is shown. The measured values are compared with the hourly interpolated irradiation, based on the TAO and ARM sites. Besides, long-term irradiation data based on 22 years from the NASA [64] are shown, in order to show the deviation of the selected year with the long-term average.

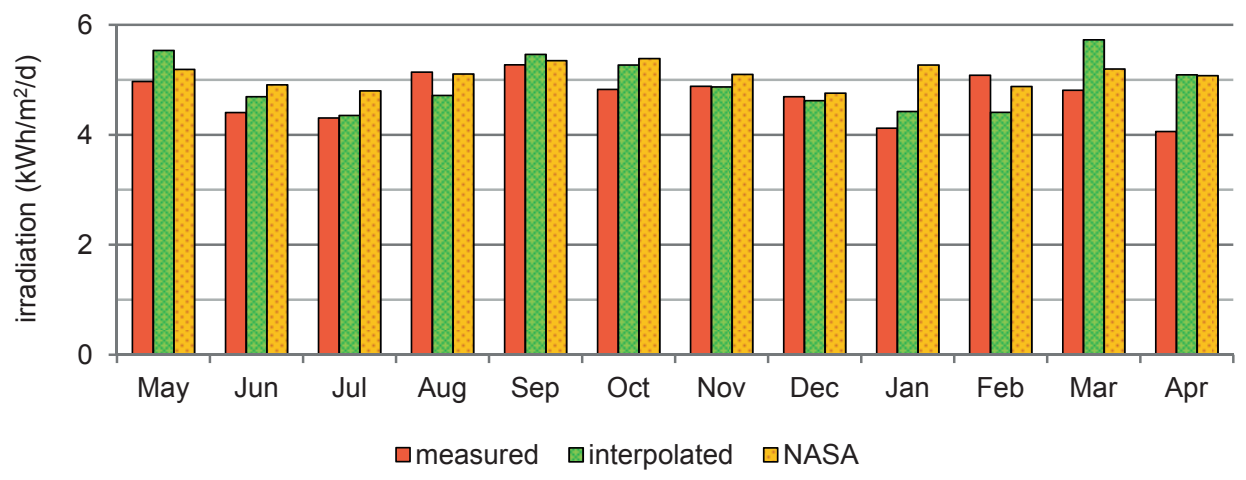

Fig. 6.14. Average daily irradiation per month. Measured in Jayapura, interpolated based on meteorological sites and long-term irradiation data from the NASA. 
Overall, the long-term monthly average daily irradiation is slightly higher compared with the measured and interpolated irradiation. In general, the measured monthly averaged daily irradiation values correspond well with the interpolated values, however from February to April the deviations are larger compared with the other months.

In Fig. 6.15 the hourly measured vs. simulated DC power output of the $12 \mathrm{~kW}_{\mathrm{p}} \mathrm{PV}$ array is shown for May 2013. The figure shows that the simulated power corresponds significantly less to the measured power output compared with the minutely simulation as shown in Fig. 6.6.

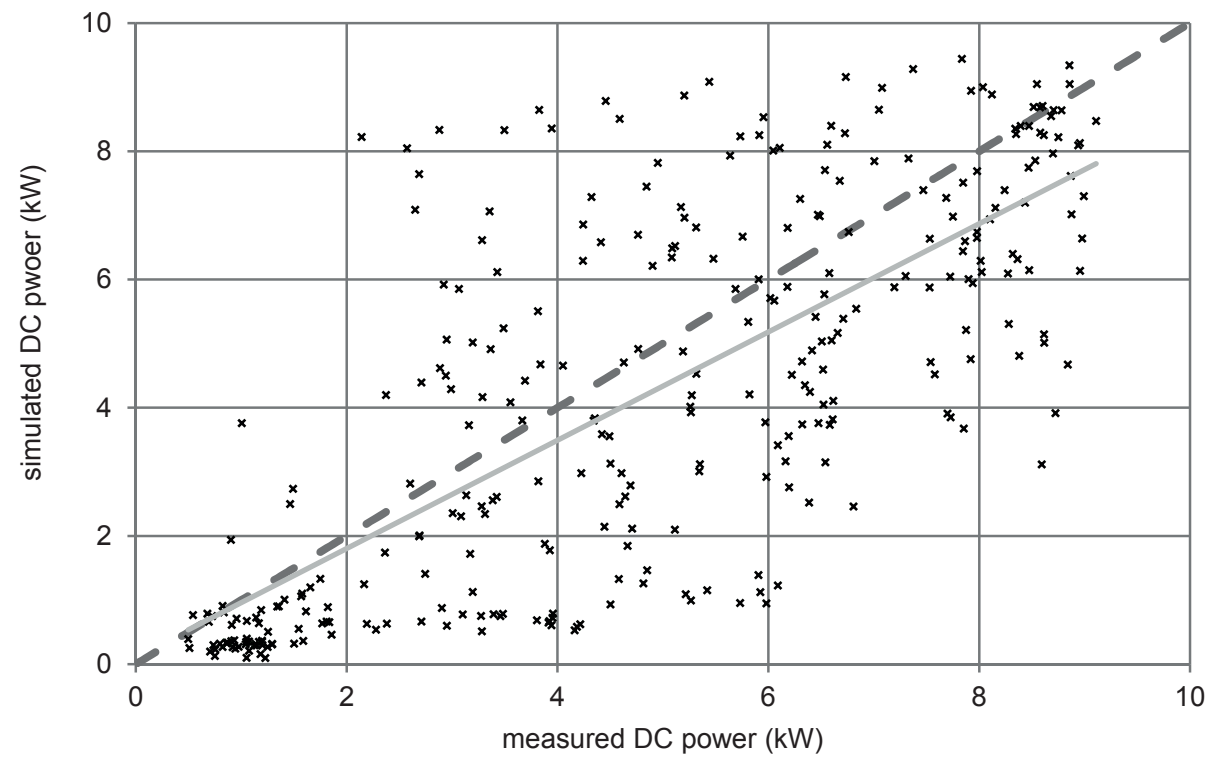

Fig. 6.15. Measured versus simulated hourly DC power output $(\mathrm{kW})$ of the $12 \mathrm{~kW}$ PV array of the PV system in Jayapura for May 2013. The solid line is the linear regression, the dashed line $\mathrm{x}=\mathrm{y}$ is a guide for the eye.

In Fig. 6.16 the measured vs. simulated monthly DC electricity production (kWh) is shown. The minutely simulated results are based on the minutely measured weather data in Jayapura. The hourly results are based on the hourly publicly available weather data.

As can be seen from Fig. 6.16, the electricity production based on the minutely data has been simulated well, with on average a deviation of $3.1 \%$ relative to the measured monthly DC electricity production. The hourly simulation shows some larger errors, with on average a deviation of $\pm 8 \%$ relative to the measured monthly DC electricity production.

The larger error of the hourly simulation can be largely explained by the difference in measured irradiation at the meteorological sites compared with the measured irradiation in Jayapura. The irradiation based on the meteorological sites amounts to $1,713 \mathrm{kWh} / \mathrm{m}^{2}$, for 
Jayapura this is $1,629 \mathrm{kWh} / \mathrm{m}^{2}$ for the period May 2013 - April 2014. Based on monthly totals, the difference in measured irradiation varies between $1-29 \mathrm{kWh} / \mathrm{m}^{2}$.

Since erroneous and missing measurement records are excluded from the analysis, the monthly average daily irradiation as shown in Fig. 6.14 is not directly comparable with the electricity production as shown in Fig. 6.16.

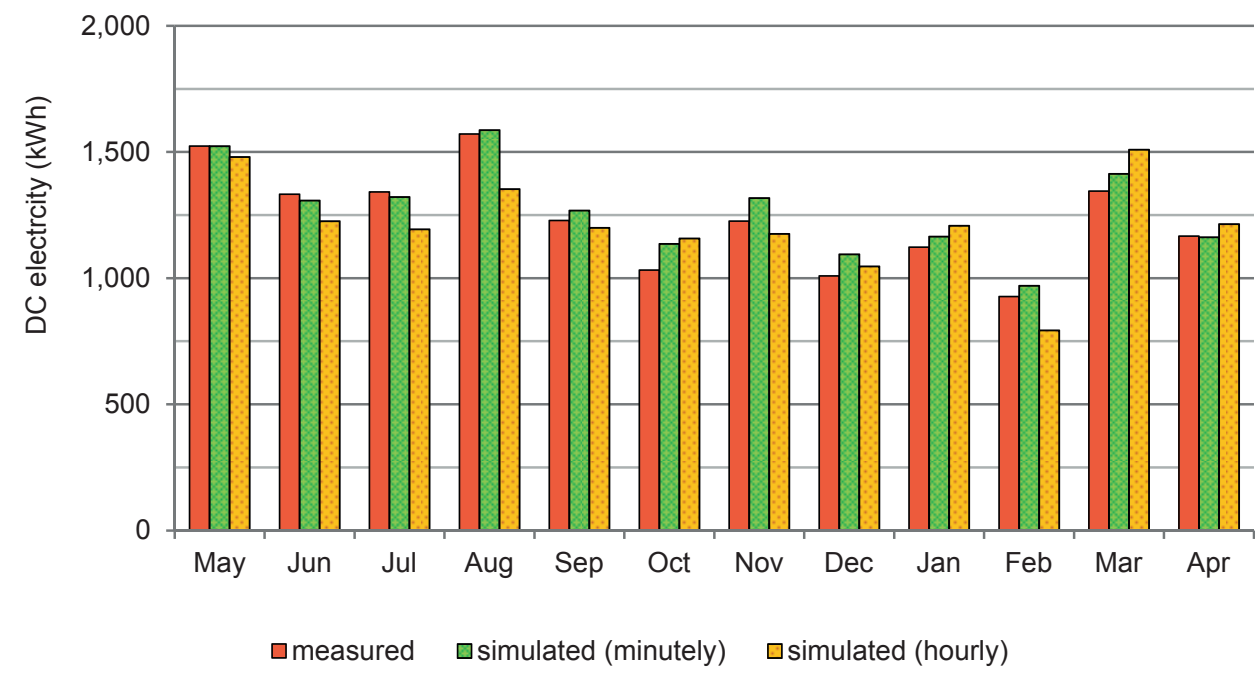

Fig. 6.16. Measured versus simulated monthly DC electricity output (kWh) of the $12 \mathrm{~kW}_{\mathrm{p}} \mathrm{PV}$ array of the PV system in Jayapura for May 2013 - April 2014.

In Fig. 6.17 the hourly simulated vs. measured DC power output of the $12 \mathrm{~kW}$ PV array is presented, based on the TAO and ARM data.

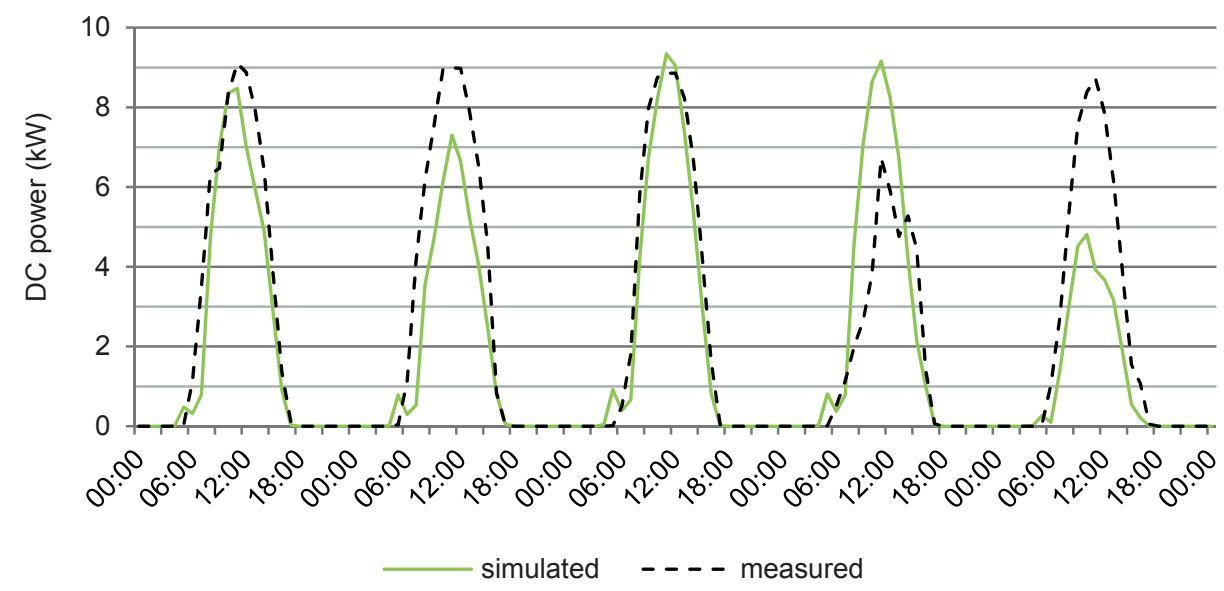

Fig. 6.17. Hourly simulated vs. measured DC power (kW) for the $12 \mathrm{~kW}$ PV array in Jayapura for the $4^{\text {th }}-8^{\text {th }}$ of May 2013. Input data based on TAO and ARM measurements. 
From Fig. 6.17 it can be seen that the trend of the DC power output is simulated well, however at some hours the difference between simulated and measured power is more than a factor 3. This can be explained by the difference in weather conditions at the PV system site and the meteorological sites during these periods.

TABLE 6-2: RMSE OF THE HOURLY SIMULATED DC POWER OUTPUT

\begin{tabular}{lrrrrrr}
\hline Month & $\begin{array}{r}\text { avg } P_{\text {meas }} \\
(\mathbf{W})\end{array}$ & $\begin{array}{r}\text { RMSE } \text { sim }^{*} \\
(\mathrm{~W})\end{array}$ & $\begin{array}{r}\text { RMSE } \mathbf{P}_{\text {sim }}{ }^{* *} \\
(\%)\end{array}$ & $\begin{array}{r}\mathrm{E}_{\text {meas }} \\
(\mathrm{kWh})\end{array}$ & $\begin{array}{r}\mathrm{E}_{\text {sim }} \\
(\mathrm{kWh})\end{array}$ & $\begin{array}{r}\text { rel. err. } \mathrm{E}_{\text {sim }} \\
(\%)\end{array}$ \\
\hline May & 4,774 & 2,224 & $47 \%$ & 1,532 & 1,480 & $-3.5 \%$ \\
\hline Jun & 4,456 & 2,172 & $49 \%$ & 1,341 & 1,226 & $-9.4 \%$ \\
\hline Jul & 4,253 & 2,383 & $56 \%$ & 1,344 & 1,194 & $-12.6 \%$ \\
\hline Aug & 4,701 & 2,153 & $46 \%$ & 1,575 & 1,353 & $-16.4 \%$ \\
\hline Sep & 4,850 & 2,076 & $43 \%$ & 1,227 & 1,200 & $-2.3 \%$ \\
\hline Oct & 4,148 & 2,428 & $59 \%$ & 1,033 & 1,158 & $10.8 \%$ \\
\hline Nov & 4,182 & 2,272 & $54 \%$ & 1,221 & 1,175 & $-3.9 \%$ \\
\hline Dec & 3,898 & 2,396 & $61 \%$ & 1,006 & 1,047 & $3.9 \%$ \\
\hline Jan & 3,538 & 2,159 & $61 \%$ & 1,118 & 1,208 & $7.5 \%$ \\
\hline Feb & 4,228 & 2,310 & $55 \%$ & 922 & 794 & $-16.1 \%$ \\
\hline Mar & 4,077 & 2,713 & $67 \%$ & 1,341 & 1,509 & $11.1 \%$ \\
\hline Apr & 3,984 & 2,557 & $64 \%$ & 1,171 & 1,215 & $3.6 \%$ \\
\hline Average & 4,257 & 2,320 & $55 \%$ & 1,236 & 1,213 & $-2.3 \%$ \\
\hline
\end{tabular}

The average $\mathrm{P}_{\text {meas }}$ and the RMSE $\mathrm{P}_{\text {sim }}$ are based on irradiance levels $G_{\text {hor }}>50 \mathrm{~W} / \mathrm{m}^{2}$

** The relative RMSE $\mathrm{P}_{\text {sim }}$ is relative to avg $\mathrm{P}_{\text {meas }}$

As can be seen from Table 6-2, the RMSE of this hourly simulation is $2.3 \mathrm{~kW}$ on average for the period May 2013 - April 2014. This corresponds to 55\% of the average power output for irradiance values exceeding $50 \mathrm{~W} / \mathrm{m}^{2}$.

The total electricity measured during the period May 2013 - April 2014 is $14,826 \mathrm{kWh}$. The minutely simulated electricity production for this period is $15,269 \mathrm{kWh}$, corresponding to a relative error of $3 \%$. The hourly simulated electricity production based on the publicly available weather data for the same period is $14,559 \mathrm{kWh}$, corresponding to a relative error of $-2 \%$. Based on the monthly electricity production the relative error varies between $-16-11 \%$. 


\subsection{Discussion of the simulation results}

The measured DC power output of the STP1 PV array is based on the assumption that the unmeasured PV string delivers the same amount of power as the measured one. Although both PV strings consist of twenty identical PV modules, which are placed next to each other and shadows play a small role, this assumption does not have to be true.

The simulations based on minutely input data show an average RMSE of $12 \%$ for the estimation of the power output for an irradiance range of $200-1,200 \mathrm{~W} / \mathrm{m}^{2}$. Simulations for the months before October 2013 show a better accuracy with RMSEs of 7-9\%. In the previous Chapter 5 it was found that the PV system experienced some faulty behavior in October, the high relative error of $9 \%$ could be related to this.

For the same irradiance range an average RMSE of $8 \%$ is found for the estimation of the titled irradiance. With an average DC efficiency for the STP1 PV array of 13\%, this corresponds to roughly $1 \%$ of the power output.

For the same irradiance range, the inaccuracy of the PV module temperature model corresponds to an average RMSE of about $2 \%$ of the power output for the studied PV modules. It is found that about $0.4 \%$ percentage point of this RMSE of $2 \%$ is introduced by the inaccuracy of the irradiance model. As such, the inaccuracy of the PV module temperature model adds more to the final RMSE for the power output than the inaccuracy of the models used for the translation of horizontal to tilted irradiance.

The rest of the inaccuracy of the power output modeling can either be caused by the applied models or by losses inside the PV system which are not included in the modeling. Inaccuracies caused by the models could be related to the applied PV module parameters and the implemented one-diode model. Inaccuracies caused by the PV system could be related to power losses due to wire resistances or due to malfunctioning PV cells causing mismatches in the optimal operating point.

\subsection{Conclusions}

The simulation based on minutely measured global horizontal irradiance produces reasonable values for the DC power output. The monthly average RMSE is found to be in the range of $350-740 \mathrm{~W}$ for a PV array of $12 \mathrm{~kW}$, corresponding to respectively $7 \%$ and $18 \%$ of the monthly average DC power output for the period May 2013 - April 2014 for irradiance levels exceeding $50 \mathrm{~W} / \mathrm{m}^{2}$.

The minutely simulated PV module temperature shows a RMSE of roughly $4{ }^{\circ} \mathrm{C}$, corresponding to $10 \%$ of the average measured PV module temperature. With a temperature coefficient for the maximum power of $-0.42 \% /{ }^{\circ} \mathrm{C}$, this corresponds to an average error of around $2 \%$ of the power output.

The hourly simulation of the DC power output based on publicly available irradiance data shows less accurate results. The average RMSE is found to be about $2.3 \mathrm{~kW}$ for the 12 
$\mathrm{kW}_{\mathrm{p}} \mathrm{PV}$ array, corresponding to $55 \%$ relative to the average measured DC power output for the period from May 2013 - April 2014.

Although the publicly available weather data are measured at a distance too far away from the PV system site in Jayapura to simulate the hourly power output accurately, these data can be used to determine the total monthly electricity production. Based on hourly measurements covering a year, the relative error is found to be $-2 \%$ of the total measured electricity production. Evaluations per month show a relative error varying between $-16 \%-$ $11 \%$ of the total monthly measured electricity production.

Overall, the RMSE shows fairly low values at medium to high irradiance levels which shows that the underlying irradiance and temperature models which are implemented in the VR4PV are appropriate to simulate the power output of PV systems in Indonesia. 



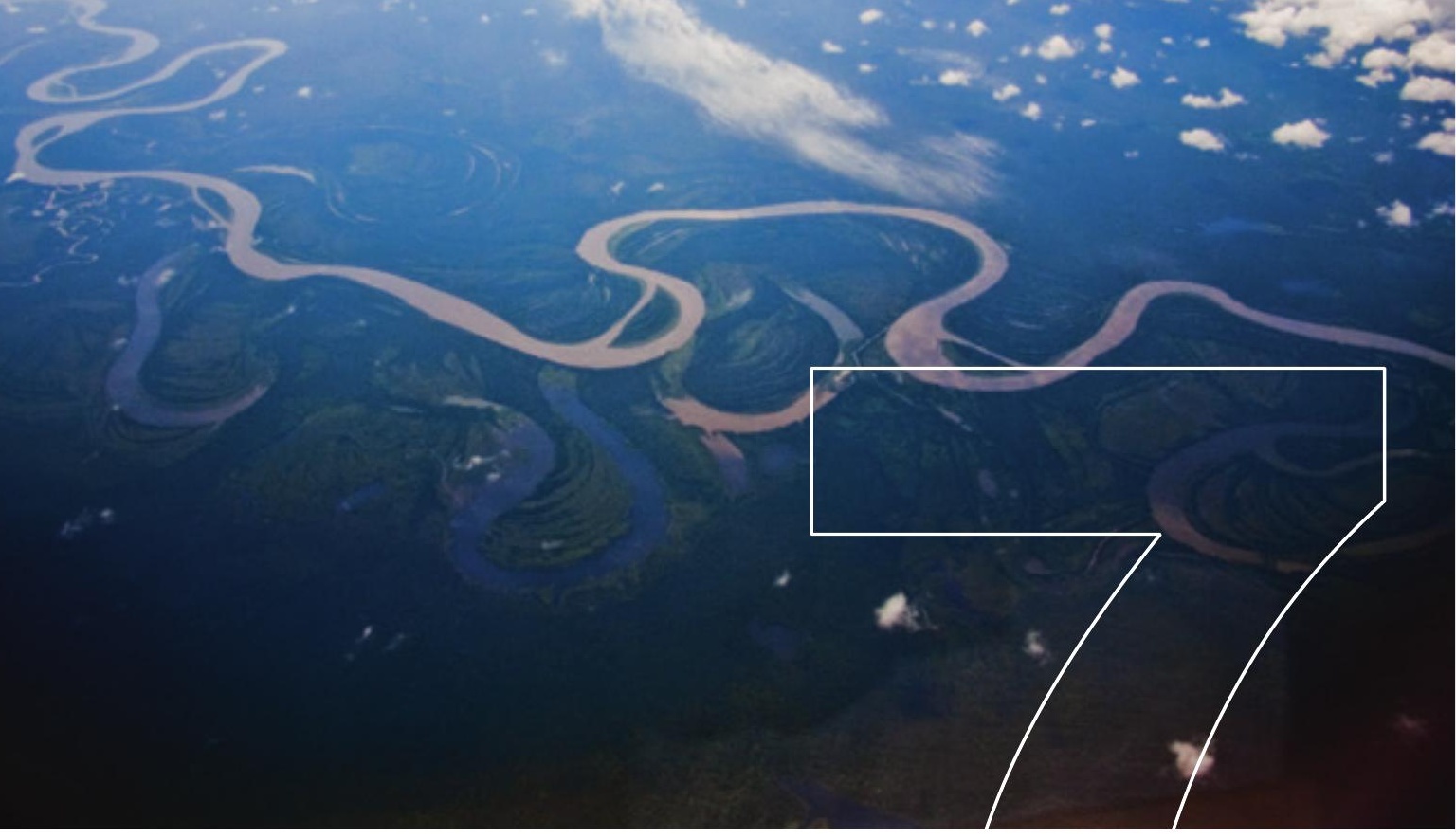

\section{Simulation of the PV}

\section{module temperatures at}

\section{small time scales}

This Chapter is based on a study which has been published as manuscript in the Journal of Photovoltaics. A.J. Veldhuis, A.M. Nobre, I.M. Peters, T. Reindl, R. Rüther, A.H.M.E. Reinders, An Empirical Model for Rack-Mounted PV Module Temperatures for Southeast Asian Locations Evaluated for Minute Time Scales, volume 5, no.3, pp.774-782, May 2015. 


\section{7}

\section{Simulation of the PV module temperatures at small time scales}

In this chapter a new PV module temperature model is developed and is evaluated against similar existing models on a minutely basis in order to find the most suitable model to be applied for PV systems in tropical areas.

\subsection{Introduction}

It is expected that PV systems will play an increasing role in the electricity mix in Indonesia and other Southeast Asian countries. In order to be able to balance the supply and demand of electricity in the grid in an efficient manner, short-term power output forecasting of the variable electricity generation from PV systems becomes important. It is well known that the operating temperature has a strong influence on the power output of photovoltaic devices, leading to a reduction in generated voltage and power with higher module temperatures [127]. So, an increased accuracy in the simulated short-term PV module temperature will help to better simulate the actual PV power output.

From previous chapter it was found that the accuracy of the implemented PV module temperature model was roughly $4{ }^{\circ} \mathrm{C}$ based on minutely measurements. This resulted in an average RMSE of roughly $2 \%$ of the power output for the studied mono-crystalline PV modules. Which can be an acceptable error for power output forecasting, however this RMSE is an average over the complete day: the smaller errors during periods of low irradiances at the end and begin of the day offset the larger errors around midday. This can be observed in Fig. 6.10 as well, in which the temperature model performs significant less during the hours around noon. Especially during periods with high irradiance levels, the power output of PV systems is high and hence the absolute power loss due to the increased PV module temperature is large. So, for short-term power output forecasting the period corresponding to the larger errors produced by the implemented PV temperature model, as described in the previous chapter, are important in particular.

Since the simulated PV module temperature as discussed in the previous chapter was influenced by the inaccuracy of the irradiance as well, a more thoroughly study is required to evaluate the performance of PV module temperature models in tropical areas such as Indonesia. 
Considerable research has been carried out on this topic and a wide range of models have been developed to determine the PV module temperature [83, 84, 128-131]. However, most of these studies focused on PV systems in areas at higher latitudes, which experience different climatic conditions compared with a tropical country as Indonesia, such as higher average irradiance and humidity levels. Besides, some temperature models are based on hourly averages and used for long-term PV performance studies [84, 130]. Furthermore, most studies such as [128], exclude the transient weather conditions to model the PV module temperature, although these variable conditions are particularly important for power forecasting. Additionally, over half of the irradiation received in Singapore can be classified as fluctuating irradiances [132]; this underlines the necessity to include these transient conditions in the model and to use high time resolution measurement data. Moreover, due to the thermal inertia of PV modules, it is necessary to take the temperature lag into account $[129,131,133]$.

For the modeling of the PV module temperature there exist physical and empirical models. The physical models simulate the PV module temperature based on heat transfer models [129, 131, 134], which require many input parameters. Empirical models have the advantage that less input parameters are required, although this comes often at the expense of accuracy. Most of these empirical models include ambient temperature, irradiance, wind speed and some module mounting coefficient.

The aim of this study is to find a simple empirical model based on weather variables which are measured by standard meteorological stations to determine the PV module backsurface temperature on a short time interval in Southeast Asian areas with a better accuracy than similar existing models. Three of such existing models will be discussed next.

The most widely spread model is the Ross model [135], a simple correlation which takes the ambient temperature $T_{a}$ and the irradiance received by the PV module $G_{m}$ into account:

$T_{m}=T_{a}+k G_{m}$

where the Ross coefficient $k$ is an empirical value which relates the irradiance to the PV module temperature $T_{m}$. A common value for $k$ is $0.025^{\circ} \mathrm{C} \cdot \mathrm{m}^{2} / \mathrm{W}$, however Ye et al. [136] found that values vary between $0.013-0.037{ }^{\circ} \mathrm{C} \cdot \mathrm{m}^{2} / \mathrm{W}$ for a tropical location as Singapore depending on several factors such as rooftop material. This qualitative study did not take wind into account; however, among the factors found to influence module temperatures, natural site ventilation had the largest impact with a potential beneficial effect on $k$ of up to $50 \%$. 
In contrast to the Ross model, the model of King et al. [83] includes the wind speed to determine the PV module temperature:

$T_{m}=G_{m}\left\{e^{a+b \cdot W S}\right\}+T_{a}$

where $a$ and $b$ are empirical coefficients and WS is the wind speed at $10 \mathrm{~m}$ height.

Another model which includes the wind speed as well, is the model of Skoplaki et al. [125]:

$T_{m}=T_{a}+\omega\left(\frac{0.32}{8.91+2.0 V_{f}}\right) G_{m}$

where $V_{f}$ is the free wind speed $\left(V_{f}>0 \mathrm{~m} / \mathrm{s}\right)$ and $\omega$ is the so-called "mounting coefficient" defined as the ratio of the Ross coefficient for the mounting situation at hand to the Ross coefficient for a well-ventilated, free-standing system. This latter model has been implemented in the VR4PV as well, as described in the previous chapter.

In 2013, the influence of wind on the PV module temperature in tropical areas has been evaluated based on hourly measurement data [137]. In this study a similar methodology will be used to find the most accurate PV module temperature model, but now based on a higher temporal scale, taking minutely measurements into account which is suitable for short-term power forecasting.

In order to evaluate the PV module temperature models for a larger geographic coverage, monitoring data of two PV systems in different locations in Southeast Asia will be used.

\subsubsection{Research questions}

The main research question is: How do existing empirical PV module temperature models perform in Southeast Asian areas at a one-minute interval and how can they be improved?

- What are the weather characteristics at the two tropical locations?

- Which weather variables influence the PV module temperature the most in these tropical areas and how?

- When do existing models fail to model the short-term PV module temperature accurately and how can this be improved?

- What is the accuracy of the temperature models at higher irradiance levels?

- Which model is the most suitable model to apply in these areas? 


\subsubsection{Outline}

In the following section the proposed model will be discussed. The next section will present the weather data and the experimental setup. The section starts with the description of the PV system and sensor details, followed by the characteristics of the weather at the investigated locations. The section continues with a parameter fitting of the proposed model and ends with the validation setup. In the subsequent section measurements will be used to evaluate the proposed model together with the existing temperature models for various PV module technologies at the two locations, the results will be presented. Next, the results will be discussed and eventually conclusions will be drawn.

\subsection{The proposed model}

The model proposed in this study is based on the Ross model (7.1) and is extended to account for the influence of the wind speed and radiative cooling. The wind speed affects the PV module temperature due to convective heat transfer, while radiative cooling is mainly noticeable during night times, although it can influence the module temperature during low irradiance levels as well.

First, the part of the PV module temperature due to radiative heat transfer $T_{r}$ is calculated:

$T_{r}=k G_{m}-\Delta T_{r c}$

where $\Delta T_{r c}$ is the average temperature difference between the ambient and PV module temperature due to radiative cooling during night time. Next, the convective heat transfer is included to obtain the PV module's back-surface temperature $T_{m}$ :

$T_{m}=T_{a}+T_{r}\left(1-h v_{w}^{\lambda}\right)$

where $h$ is the convective heat transfer coefficient, $v_{w}$ is the average wind speed $(\mathrm{m} / \mathrm{s})$ and $\lambda$ is an empirical exponential factor influencing the impact which the wind speed has on the convective heat transfer.

A first analysis showed that the best fit for parameter $k$ varied significantly for the PV systems in the two locations analyzed in this study: Singapore $(k=0.044)$ and Jayapura $(k=$ 0.057). Although the ambient temperatures, wind speeds and irradiance levels were similar, it was found that the relative humidity $(\mathrm{RH})$ varied significantly for both locations (see Fig. 7.4). In Singapore, the average RH for irradiance levels exceeding $500 \mathrm{~W} / \mathrm{m}^{2}$ was found to be $68 \%$, while in Jayapura, this was only $38 \%$.

$\mathrm{RH}$ influences the heat capacity of air, which could therefore impact the convective heat transfer, however the influence of humidity on the heat transfer by natural convection is negligible for the relatively low PV module temperatures during operation [138]. Based on 
an analysis of the measurements, it has been found that including the $\mathrm{RH}$ in the radiative part improves the accuracy of the model. Therefore, formula (7.4) has been adapted to include the $\mathrm{RH}$ as an additional parameter:

$T_{r}=(k+\gamma[1-R H]) G_{m}-\Delta T_{r c}$

where $\gamma$ is a constant, which influences the extent which the $R H$ (with $0 \leq R H \leq 1$ ) has on the impact of the irradiance $G_{m}$ on the PV module temperature. With lower values for the $\mathrm{RH}$, the impact of the irradiance will be higher.

Since the temperature lag is found to follow an exponential response [129, 131], the thermal inertia is simulated by an exponential moving average (EMA). The actual PV module temperature at the time corresponding to record $j$ is calculated by the EMA of (7.5) over a period of $t$ minutes:

$T_{m, E M A, j}=T_{m, j} \frac{2}{t+1}+T_{m, E M A, j-1}\left(1-\frac{2}{t+1}\right)$

For the initial value of $T_{m, E M A, j-1}$ the normal average is used.

\subsection{Weather data and experimental setup}

This study will evaluate empirical models for the PV module temperature for two PV systems in Southeast Asia, namely one in Jayapura - as described in chapter 5 - and the other in Singapore. The PV system in Singapore is a demonstration site, built and monitored by the Solar Energy Research Institute of Singapore (SERIS).

\subsubsection{PV system in Singapore}

The SERIS' demonstration site in Singapore ( $\left.1^{\circ} 20^{\prime} \mathrm{N}, 103^{\circ} 40^{\prime} \mathrm{E}\right)$ is shown in Fig. 7.1 and comprises three module technologies - mono-crystalline hetero-junction silicon waferbased (hetero c-Si, HIT), amorphous silicon (a-Si) and a poly-crystalline silicon wafer-based (poly-Si), all rack-mounted on a concrete rooftop with a module height of $\sim 0.5 \mathrm{~m}$, oriented towards SW at a tilt angle of $10^{\circ}$. Pt-100 temperature probes are installed at the back of a central module of each array. A comprehensive meteorological station is located at 1 meter height above the rooftop next to the system. 


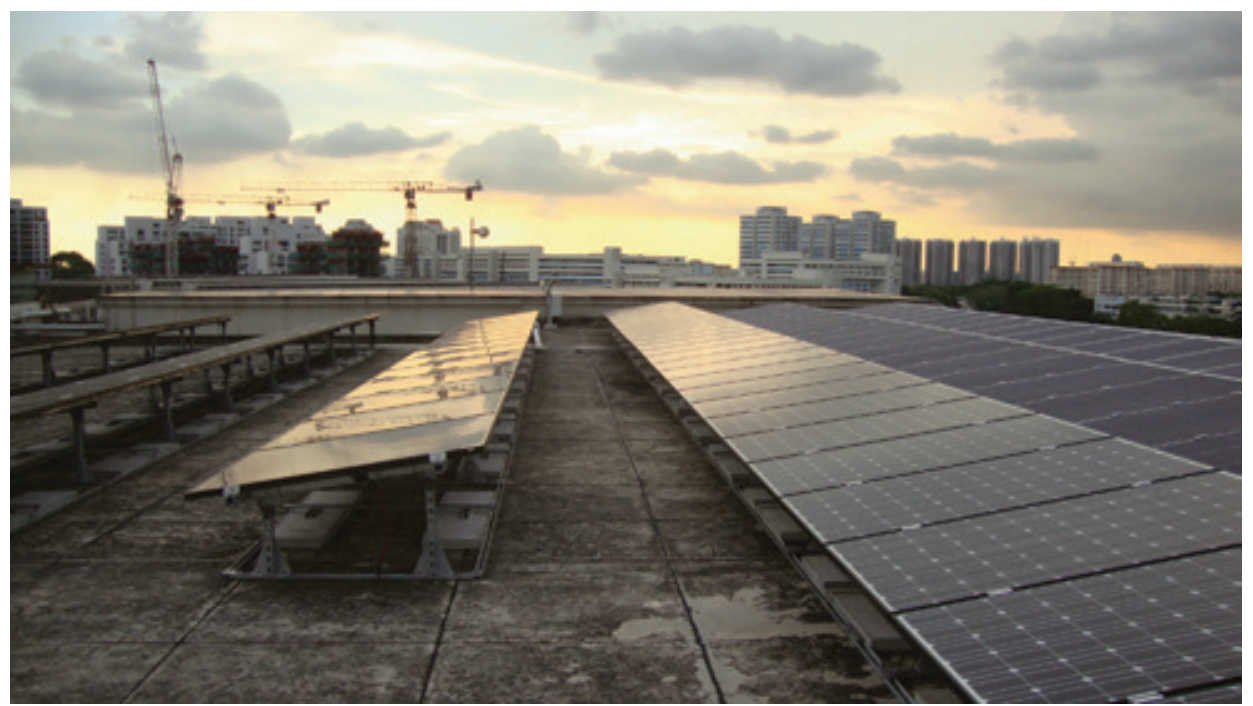

Fig. 7.1. SERIS' demonstration PV system, located at the National University of Singapore (NUS) campus.

Data used in this study cover two whole years of minutely averaged measurements for calendar years 2012 and 2013.

In Table 7-1 the details of the sensors used in Jayapura $(\mathrm{J})$ and Singapore $(\mathrm{S})$ are shown. The recording interval is once per minute (averages), the sampling rate is once per second.

TABLE 7-1: SENSORS DETAILS

\begin{tabular}{lllll}
\hline Site & Variable & Sensor & Unit & Accuracy \\
\hline $\mathrm{J}$ & POA irradiance & $\begin{array}{l}\text { Mencke \& Tegtmeyer silicon } \\
\text { reference cell }\end{array}$ & $\mathrm{W} / \mathrm{m}^{2}$ & $5 \%$ \\
\hline $\mathrm{J}$ & Ambient temperature & WeatherHawk 232 & ${ }^{\circ} \mathrm{C}$ & $0.5^{\circ} \mathrm{C}$ \\
\hline $\mathrm{J}$ & Wind speed & WeatherHawk 232 & $\mathrm{m} / \mathrm{s}$ & - \\
\hline $\mathrm{J}$ & Relative humidity & WeatherHawk 232 & $\%$ & $3-5 \%$ \\
\hline $\mathrm{J}$ & Module temperature & Campbell Scientific Pt100/3 & ${ }^{\circ} \mathrm{C}$ & $0.2{ }^{\circ} \mathrm{C}$ \\
\hline $\mathrm{S}$ & POA irradiance & $\begin{array}{l}\text { Mencke \& Tegtmeyer silicon } \\
\text { reference cell }\end{array}$ & $\mathrm{W} / \mathrm{m}^{2}$ & $5 \%$ \\
\hline $\mathrm{S}$ & Ambient temperature & $\begin{array}{l}\text { Thies Clima Hygro- } \\
\text { ThermoTransmitter-compact }\end{array}$ & ${ }^{\circ} \mathrm{C}$ & $0.2{ }^{\circ} \mathrm{C}$ \\
\hline $\mathrm{S}$ & Wind speed & $\begin{array}{l}\text { Thies Clima Wind transmitter } \\
\text { compact }\end{array}$ & $\mathrm{m} / \mathrm{s}$ & $3 \%$ \\
\hline $\mathrm{S}$ & Relative humidity & $\begin{array}{l}\text { Thies Clima Hygro- } \\
\text { ThermoTransmitter-compact }\end{array}$ & $\%$ & $2 \%$ \\
\hline $\mathrm{S}$ & Module temperature & Pt100, Class B & ${ }^{\circ} \mathrm{C}$ & $0.2{ }^{\circ} \mathrm{C}$ \\
\hline
\end{tabular}


The data from Jayapura used in this study cover minutely averaged measurements from May 2013 - March 2014. If not explicitly stated otherwise, measurements applied in this study will include records during daytime only.

\subsubsection{Weather characteristics}

In tropical regions the average wind speeds are usually low, as can be seen in Fig. 7.2, in which the frequency distributions of the wind speeds for Singapore and Jayapura are shown at $0.5 \mathrm{~m} / \mathrm{s}$ bins. Most wind speeds during daylight time are below $3 \mathrm{~m} / \mathrm{s}$; for Singapore this covers $95 \%$ and $96 \%$ of the wind speeds measured in 2012 and 2013 respectively. For Jayapura this corresponds to $93 \%$ of the wind speeds ${ }^{22}$.

Because of these prevailing low wind speeds, the Ross model - which ignores the wind speeds - gives reasonable results [136, 137]. However, for high irradiance levels and, hence, high PV module temperatures, even small wind speeds will have an influence on the PV module temperature.

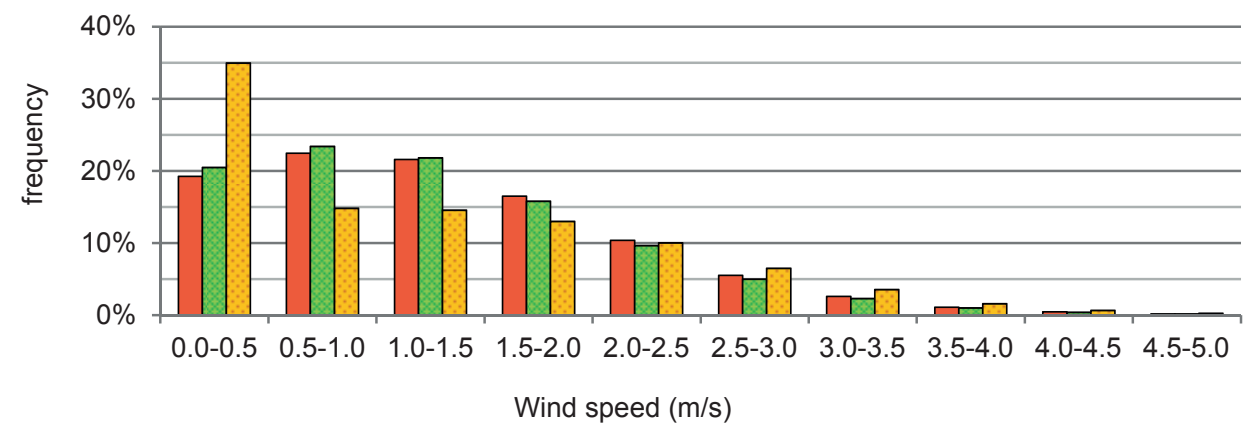

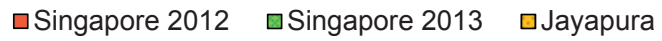

Fig. 7.2. The frequency of various wind speeds $(\mathrm{m} / \mathrm{s})$ for Singapore and Jayapura based on minutely averaged measurements.

In Fig. 7.3 the distributions of the annual irradiation per irradiance bin of $50 \mathrm{~W} / \mathrm{m}^{2}$ for Singapore and Jayapura are shown. As can be noticed, the distributions for both locations are similar; however, in Jayapura more irradiation is received in the higher irradiance range (800-1,000 W/m² range).

\footnotetext{
22 The wind speed sensor in Jayapura has a starting threshold of $0.78 \mathrm{~m} / \mathrm{s}$, in Singapore this is $0.5 \mathrm{~m} / \mathrm{s}$. This could explain the higher frequency of the lowest wind speed bin compared with Singapore. Since the measurements are averaged over a minute, the first bin will still be shown.
} 


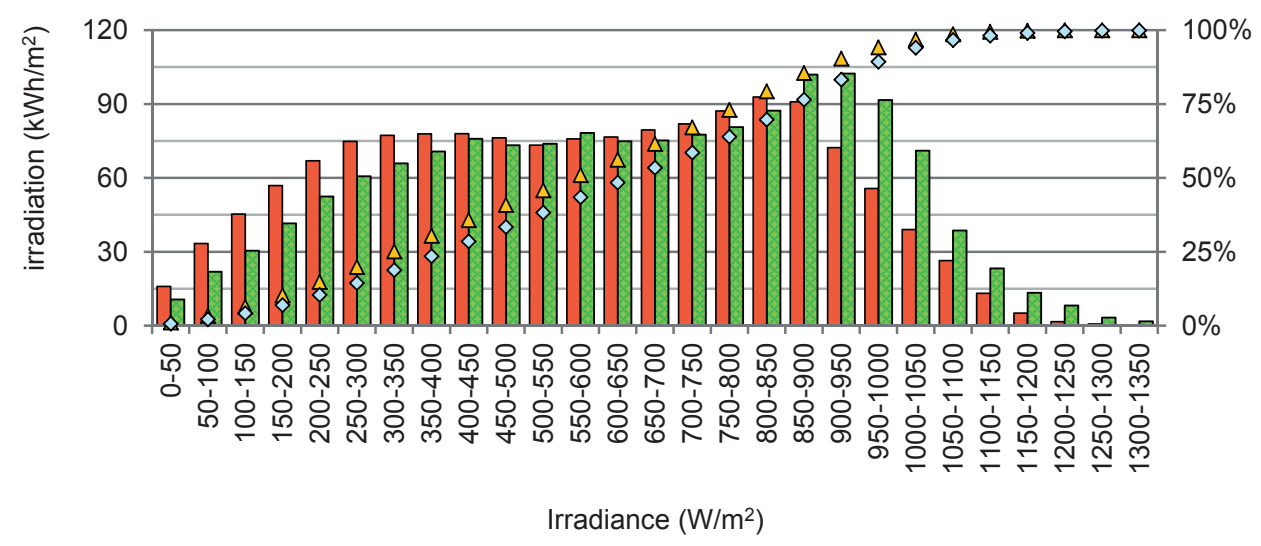

口Singapore $\square$ Jayapura $\Delta$ Singapore $(\%) \quad \diamond$ Jayapura $(\%)$

Fig. 7.3. Distribution of the annual in-plane irradiation $\left(\mathrm{kWh} / \mathrm{m}^{2}\right)$ per irradiance range of $50 \mathrm{~W} / \mathrm{m}^{2}$ for Singapore and Jayapura.

From Fig. 7.3, it can be seen that most irradiation is received during periods with irradiance levels exceeding $500 \mathrm{~W} / \mathrm{m}^{2}$, totaling $59 \%$ and $63 \%$, for Singapore and Jayapura, respectively.

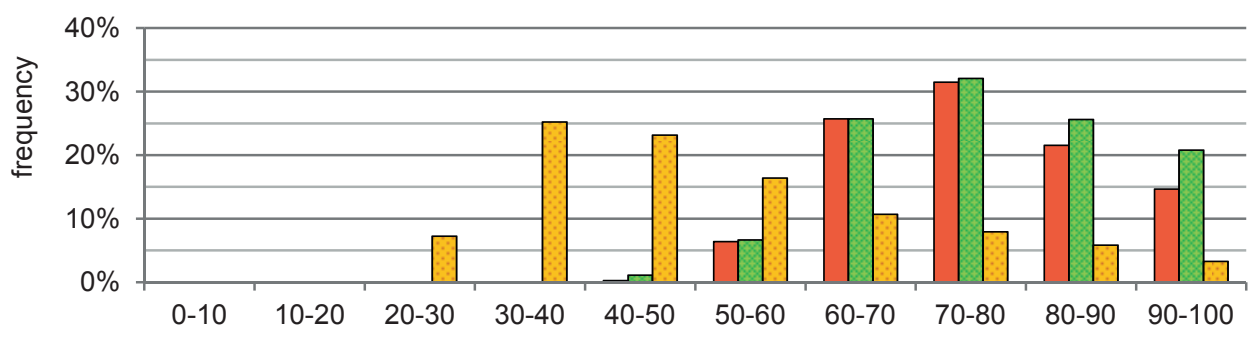

Relative humidity (\%)

\section{口Singapore $2012 \square$ Singapore $2013 \quad \square$ Jayapura}

Fig. 7.4. The frequency of relative humidity (\%) for Singapore and Jayapura based on minutely averaged measurements.

In Fig. 7.4, the frequency distributions of the RH for Singapore and Jayapura are shown. As can be observed, the variability of the RH in Jayapura is larger than in Singapore. Besides, a $\mathrm{RH}$ of roughly $40 \%$ is most frequently experienced in Jayapura while in Singapore $70 \%$ is most prevalent.

\subsubsection{Weather variables vs. PV module temperature}

In Fig. 7.5 and Fig. 7.6, the different weather variables are shown for the same day in November for Jayapura and Singapore, respectively. 


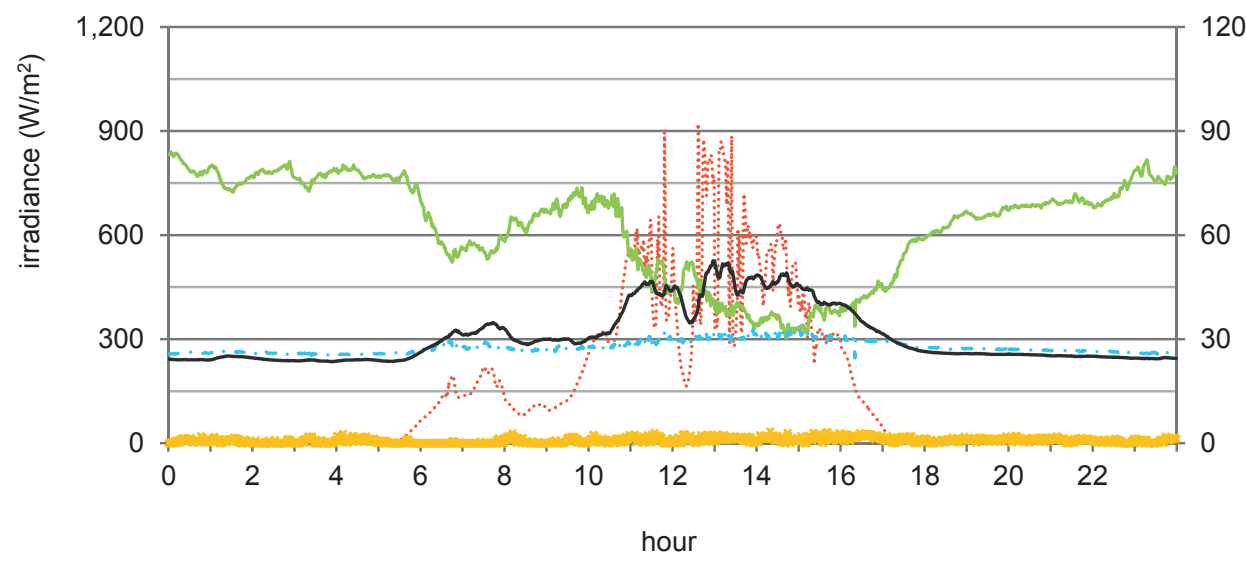

$\mathrm{Gm} \longrightarrow \mathrm{RH} \quad \times \quad \mathrm{Vw} \quad \cdots-\mathrm{Ta} \longrightarrow \mathrm{Tm}$

Fig. 7.5. The profile of various minutely averaged variables for the 26th of November 2013 in Jayapura. The irradiance $G_{m}\left(\mathrm{~W} / \mathrm{m}^{2}\right)$ is plotted against the left y-axis. The other variables, relative humidity $R H(\%)$, wind speed $v_{w}(\mathrm{~m} / \mathrm{s})$, ambient temperature $T_{a}\left({ }^{\circ} \mathrm{C}\right)$ and module temperature $T_{m}$ $\left({ }^{\circ} \mathrm{C}\right)$, are plotted against the right $\mathrm{y}$-axis.

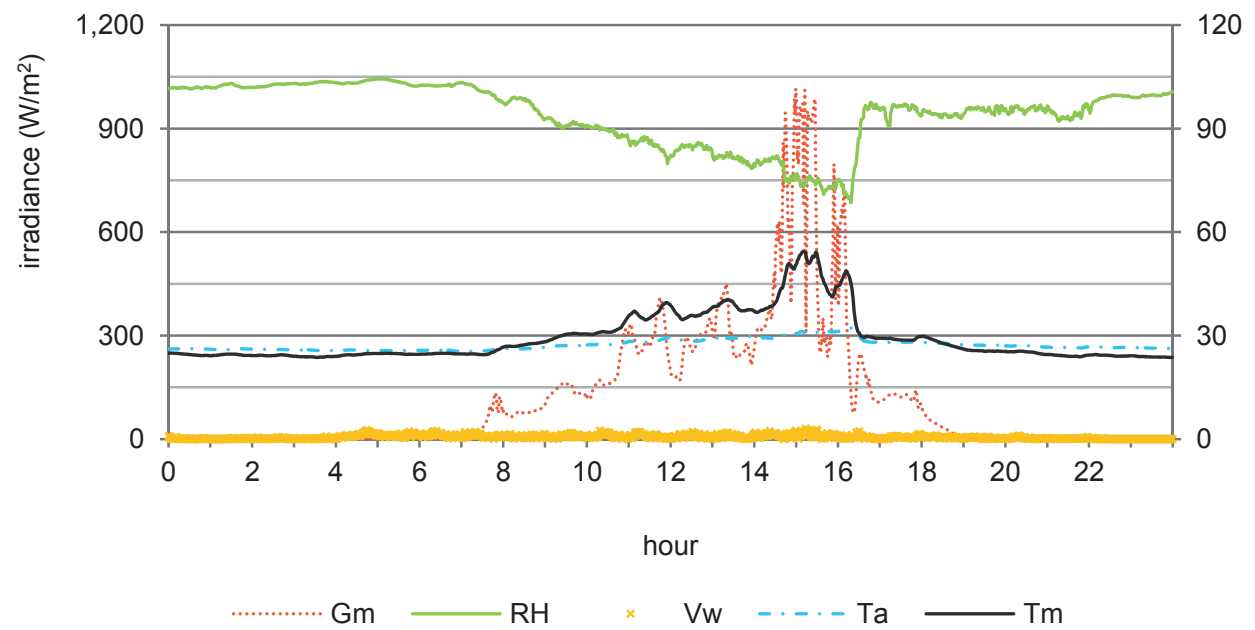

Fig. 7.6. The profile of various minutely averaged variables for the 26th of November 2013 in Singapore. The irradiance $G_{m}\left(\mathrm{~W} / \mathrm{m}^{2}\right)$ is plotted against the left y-axis. The other variables, relative humidity $R H(\%)$, wind speed $v_{w}(\mathrm{~m} / \mathrm{s})$, ambient temperature $T_{a}\left({ }^{\circ} \mathrm{C}\right)$ and module temperature $T_{m}$ $\left({ }^{\circ} \mathrm{C}\right)$, are plotted against the right $\mathrm{y}$-axis.

As can be seen from Fig. 7.5 and Fig. 7.6, the RH decreases with increasing ambient temperature. Furthermore, the RH is significantly lower in Jayapura than in Singapore.

To study the influence of the weather variables on the PV module temperature, the correlations between each of these variables with the PV module temperature are obtained.

The correlations are calculated for each PV module for the complete year 2013 for Singapore and from May - December 2013 for Jayapura. Since the deviations per PV 
module are found to be negligible, the average correlations for all PV technologies are shown in Table 7-2.

As the impact of the wind is affected by the temperature rise above ambient, and PV module temperatures are typically much hotter for irradiance levels larger than $500 \mathrm{~W} / \mathrm{m}^{2}$ [139], the evaluation in this study distinguishes two groups of measurements: (i) all records during daytime and (ii) records with irradiance levels exceeding $500 \mathrm{~W} / \mathrm{m}^{2}$.

TABLE 7-2: CORRELATIONS OF THE VARIOUS VARIABLES

\begin{tabular}{|c|c|c|c|c|}
\hline \multirow[b]{2}{*}{ Variable } & \multicolumn{2}{|c|}{ Jayapura } & \multicolumn{2}{|c|}{ Singapore } \\
\hline & $G_{m}>1 \mathrm{~W} / \mathrm{m}^{2}$ & $G_{m}>500 \mathrm{~W} / \mathrm{m}^{2}$ & $G_{m}>1 \mathrm{~W} / \mathrm{m}^{2}$ & $G_{m}>500 \mathrm{~W} / \mathrm{m}$ \\
\hline$G_{m}$ & 0.93 & 0.71 & 0.88 & 0.55 \\
\hline$v_{w}$ & 0.36 & -0.09 & 0.37 & 0.03 \\
\hline$R H$ & -0.84 & -0.65 & -0.77 & -0.51 \\
\hline$T_{a}$ & 0.85 & 0.55 & 0.84 & 0.67 \\
\hline
\end{tabular}

From the correlations shown in Table 7-2, one can see that irradiance, relative humidity and ambient temperature are strongly correlated with the PV module temperature. The wind speed is moderately correlated for lower irradiance levels and not at all for irradiance levels exceeding $500 \mathrm{~W} / \mathrm{m}^{2}$.

In general, all correlations are getting weaker for higher irradiance levels. This can be explained partially by the thermal inertia of the PV modules and the fluctuating irradiance, which is more prevalent in this higher irradiance range. Since brief irradiance peaks will not directly result in a higher PV module temperature, the linear correlation will be weaker.

\subsubsection{Parameter fitting}

The proposed model consists of six parameters: $\Delta T_{r}, k, h, \gamma, \lambda$ and $t$. The value for each of these parameters has to be found. Since the best fitting parameters cannot be determined analytically, the root-mean-square error (RMSE) of the modeled PV module temperature has been calculated for a range of values for each of these parameters. This is done for a part of the measurements, for Singapore from the year 2012 and for Jayapura from May December 2013. The aim is to find the combination of parameters, which results in the lowest RMSE.

Initial values for the parameters $\Delta T_{r c}, k$ and $h$ are obtained analytically. The first estimates for $\lambda\left(\lambda_{0}=0.25\right)$ and $t\left(t_{0}=15\right)$ are found by visually comparing the plots of the modeled versus measured PV module temperatures for some days. 
The initial value of $\Delta T_{r c}$ is the average temperature difference between the ambient and the PV module at night, which is calculated as follows:

$\Delta T_{r c}=\frac{1}{n} \sum_{j=1}^{n}\left\{T_{a, j}-T_{k, j} \mid G_{m, j}<1\right\}$

where $T_{k}$ is the measured PV module temperature for record $j$. Next, the initial value for parameter $k$ is determined by:

$k=\max _{j \in n}\left\{\frac{T_{k, j}-T_{a, j}+\Delta T_{r c}}{G_{m, j}} \mid G_{m, i}>600, v_{w, j} \leq 1\right\}$

Now it is possible to calculate the temperature for each measurement $T_{r, j}$ according to (7.4). To obtain the initial value for the parameter $h$, first the temperature difference due to the wind speed $T_{w}$ is determined by:

$T_{w, j}=\left(T_{a, j}-T_{r, j}\right) v_{w, j}^{\lambda}$

Then, $h$ is determined by:

$h=\frac{1}{n} \sum_{j=1}^{n}\left\{\frac{T_{k, j}-T_{r, j}}{T_{w, j}} \mid G_{m, j}>600, v_{w, j}>1\right\}$

Based on these initial values of the parameters, the model output is calculated for a wide range of values for each parameter in order to obtain the combination of values, which produce the lowest RMSE.

\subsubsection{Validation setup}

Simple empirical models which include dynamic behavior have not been found in literature. Besides, physical models which account for this unsteady behavior require input parameters which are hard to obtain (e.g. material properties, sky temperature). Therefore, the proposed model (7.7) will be evaluated together with the three existing empirical steady-state models according to (7.1) - (7.3) for various PV modules in Southeast Asian countries, in order to validate the proposition and to find the most suitable model for these tropical locations. By calculating the RMSE of the simulated PV module temperature per minute, the performance of the PV temperature models can be compared with each other.

The values for the combination of parameters resulting in the overall lowest RMSE for all PV modules are used for the validation; these values are shown in Table 7-3. 
TABLE 7-3: Best VALUES FOR MODEL PARAMETERS

\begin{tabular}{llll}
\hline Parameter & Symbol & Value & Unit \\
\hline Temperature difference due to radiative cooling & $\Delta T_{r c}$ & 1.4 & ${ }^{\circ} \mathrm{C}$ \\
\hline Ross coefficient & $k$ & 0.034 & ${ }^{\circ} \mathrm{C} \mathrm{m} / \mathrm{W}$ \\
\hline Convective heat transfer coefficient & $h$ & 0.30 & - \\
\hline Humidity coefficient & $\gamma$ & 0.016 & ${ }^{\circ} \mathrm{C} \mathrm{m}^{2} / \mathrm{W}$ \\
\hline Exponential wind factor & $\lambda$ & 0.33 & - \\
\hline Temperature lag time & $t$ & 17 & $\mathrm{~min}$ \\
\hline
\end{tabular}

The value for the temperature lag time $t$ has been found by determining the RMSE for all PV modules at both locations for a range of 5-30 minutes while remaining other parameters constant. Since the impact of the PV module temperature is larger at higher irradiance levels, the lag time has been evaluated for irradiance levels exceeding $500 \mathrm{~W} / \mathrm{m}^{2}$. This is done for the same part of the measurements as applied in the previous section, for Singapore from the year 2012 and for Jayapura from May - December 2013. The results are shown in Fig. 7.7.

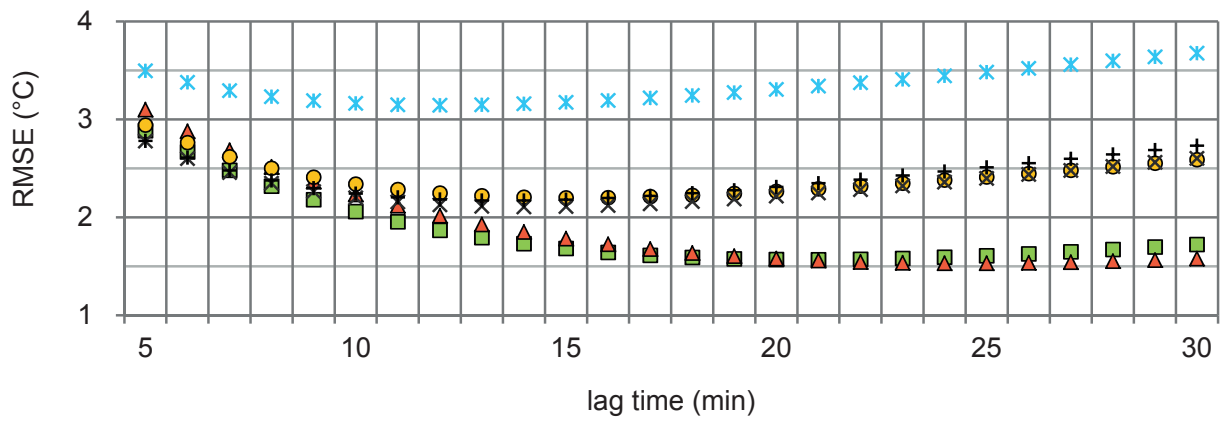

口HIT (S) $\quad \Delta \mathrm{a}-\mathrm{Si}(\mathrm{S}) \quad$ omulti-Si (S) $\quad$ mono-Si (J) $\quad \times$ mono-Si (J) $\quad+\mathrm{a}-\mathrm{Si}(\mathrm{J})$

Fig. 7.7. The RMSE for various PV modules in Singapore $(S)$ and Jayapura (J) for different temperature lag times based on the model parameter values as presented in Table 7-3.

Depending on the PV module, the lowest RMSE is found for values ranging from 12 25 minutes. The lag time, which produces the overall lowest RMSE for all PV modules, has been found to correspond to $17 \mathrm{~min}$.

For the Ross model (7.1), the value for the Ross coefficient $k$ is based on the PV module technology, rooftop material and roof distance index as proposed in the study of Ye et al. [136]. Based on their findings, seven patterns could be distinguished. All evaluated PV modules in Singapore, in this study, are similar to those with pattern P4, representing a slightly ventilated PV module on a concrete roof, with a Ross coefficient of $k=0.024^{\circ} \mathrm{C}$. 
$\mathrm{m}^{2} / \mathrm{W}$. For Jayapura, the mono-Si PV modules match with pattern P3 (i.e. mono-Si, concrete rooftop, well-ventilated), corresponding to $k=0.022{ }^{\circ} \mathrm{C} \cdot \mathrm{m}^{2} / \mathrm{W}$. The amorphous silicon PV module in Jayapura fits best in the category P2 (i.e. a-Si, concrete rooftop, wellventilated), corresponding to $k=0.017^{\circ} \mathrm{C} \cdot \mathrm{m}^{2} / \mathrm{W}$.

The values applied for the coefficients $a$ and $b$ in (7.2) are -3.56 and -0.075 , respectively, corresponding to the open rack mounting and glass/cell/polymer sheet module type [83].

The wind speed at $10 \mathrm{~m}$ height is supposed to be used in (7.2); however, the wind speeds are measured at 1 - and 3-m height in Singapore and Jayapura, respectively. It is very difficult to account for the difference in wind speeds for various heights in the built environment, because of the dominating turbulent air flows. When assuming laminar flow, the final influence is small [137] and since turbulent air flow is prevalent, these influences will be neglected in this study.

The mounting parameter $\omega$ in (7.3) is assumed to be 1, since all PV modules under investigation are free-standing.

\subsection{The accuracy of the various PV temperature models}

The results of the proposed model and the model of King et al. are shown in Fig. 7.8 for the HIT PV module in Singapore for the complete month of July 2013.

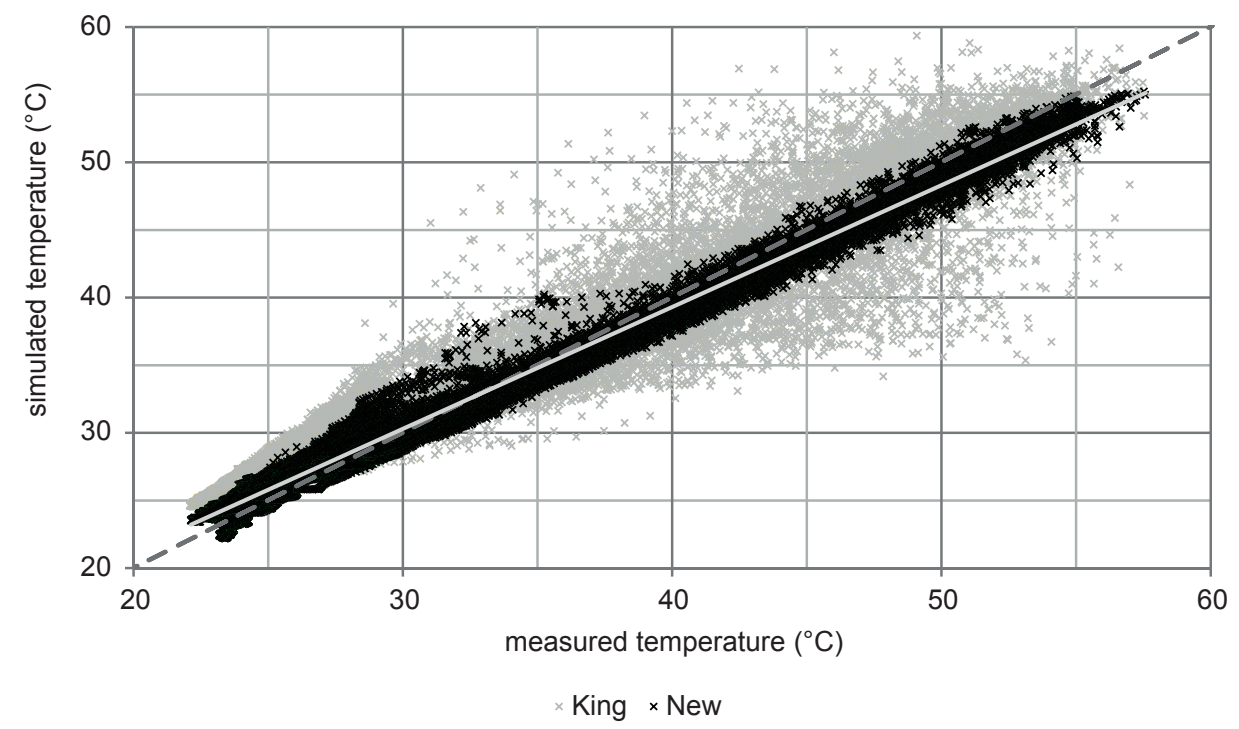

Fig. 7.8. A scatterplot of the measured PV module temperature vs. the simulated PV module temperature for the HIT PV module in Singapore for the complete month of July 2013. The simulated results are based on the proposed 'New' model and King's model. The solid line is the linear regression of the 'New' model, the dashed line $\mathrm{x}=\mathrm{y}$ is a guide for the eye. 
From Fig. 7.8 it can be seen, that the steady-state model of King et al. is under- and overestimating the actual PV module temperature under fluctuating irradiance conditions.

To show the impact of the model variables irradiance, wind speed and relative humidity on the output of the proposed model, the RMSE is calculated for: (i) irradiance only, (ii) irradiance and wind speed, (iii) irradiance and relative humidity and (iv) all three together. In Fig. 7.9 the results are shown for the different PV module technologies in Singapore and Jayapura based on minutely measurements for the whole month of July 2013 for irradiance levels exceeding $500 \mathrm{~W} / \mathrm{m}^{2}$.

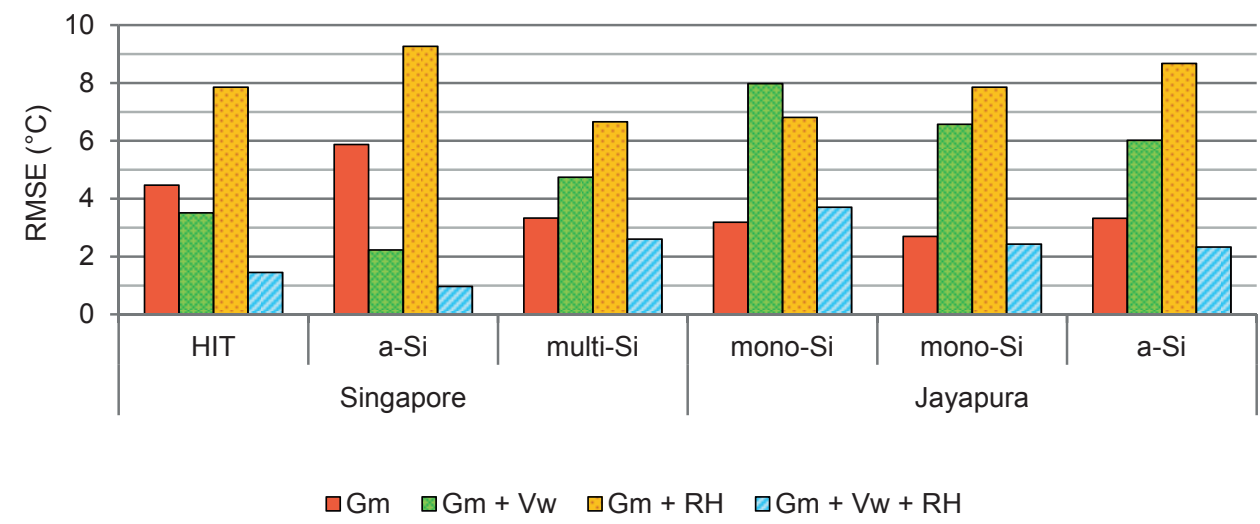

Fig. 7.9. The RMSE of the proposed model, taking different combinations of the model variables irradiance $G_{m}$, wind speed $V_{w}$ and relative humidity $R H$ into account for the different PV module technologies in Singapore and Jayapura based on minutely measurements from July 2013 for irradiance levels exceeding $500 \mathrm{~W} / \mathrm{m}^{2}$.

As can be noticed in Fig. 7.9, the three model variables have a varying impact on the RMSE for each of the different PV modules and locations. On average, including the wind speed results in a difference of $2.9^{\circ} \mathrm{C}$ compared with the RMSE based on irradiance only. For the relative humidity this average difference is $4.0{ }^{\circ} \mathrm{C}$. In general, taking only the irradiance into account produces lower RMSEs than a combination of either irradiance and wind speed or irradiance and relative humidity. Overall, including the relative humidity increases the error considerably; however, taking the wind speed simultaneously into account results in lower RMSEs compared with the RMSEs based on irradiance only. This means that the final impact of the wind in the proposed model is larger and responsible for a significant decrease in RMSE, varying between $3.1-8.3{ }^{\circ} \mathrm{C}$ with $5.6{ }^{\circ} \mathrm{C}$ on average, based on the values shown in Fig. 7.9.

In Fig. 7.10 the influence of the wind speed and RH on the equivalent Ross coefficient $k_{\text {eq }}$ is shown ${ }^{23}$. The equivalent Ross coefficients allow a comparison of the models with the

\footnotetext{
${ }^{23}$ The equivalent Ross coefficient of the proposed model is not a constant, it is influenced by the ambient temperature and incident irradiance, however these deviations are negligible.
} 
Ross model which neglects the wind speed. The values for $k_{e q}$ are obtained by calculating the slope of the line between the modeled PV module temperatures at irradiance levels of 0 and $1,000 \mathrm{~W} / \mathrm{m}^{2}$ for each model for four different wind speeds and two different $\mathrm{RH}$ levels.

As expected, the coefficient of the proposed model is significant larger compared with the other models for a wind speed of $0 \mathrm{~m} / \mathrm{s}$. For the other wind speeds in Fig. 7.10, the coefficient of the proposed model based on a $\mathrm{RH}$ of $70 \%$ is similar to the other models. The coefficient based on $40 \%$ RH remains larger compared with the other models.

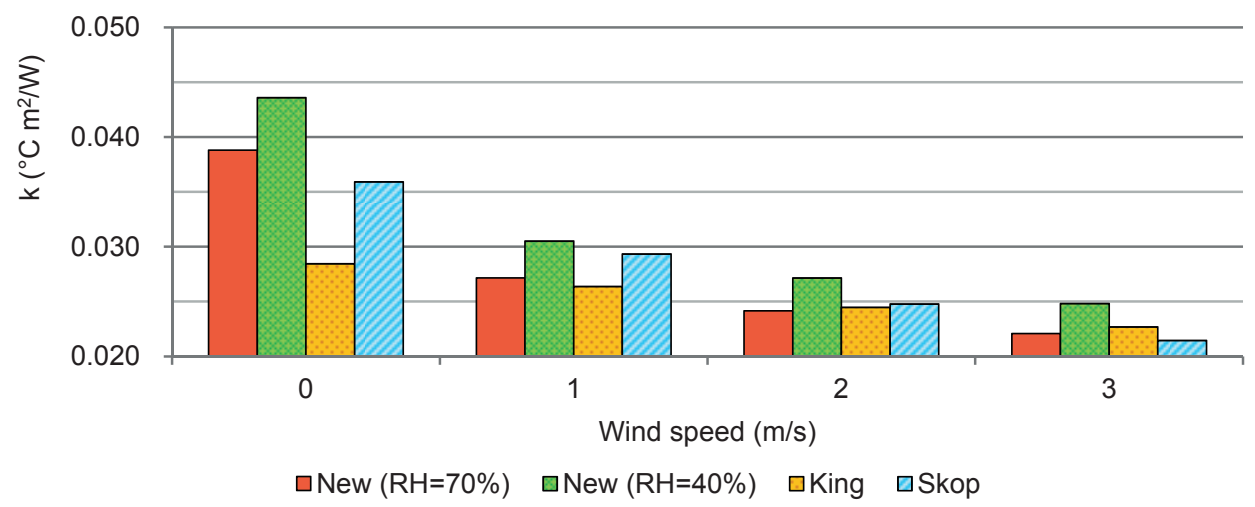

Fig. 7.10. The influence of wind speed and relative humidity on the equivalent Ross coefficient $k_{\text {eq }}$ for the different PV temperature models.

In Fig. 7.11, the cooling effect relative to the modeled PV module temperature without wind (i.e. $v_{w}=0 \mathrm{~m} / \mathrm{s}$ ) is shown for the evaluated models, which include wind speed as a model variable. The effect has been calculated for a constant ambient temperature, $\mathrm{RH}$, and irradiance of $30{ }^{\circ} \mathrm{C}, 70 \%$ and $1,000 \mathrm{~W} / \mathrm{m}^{2}$, respectively.

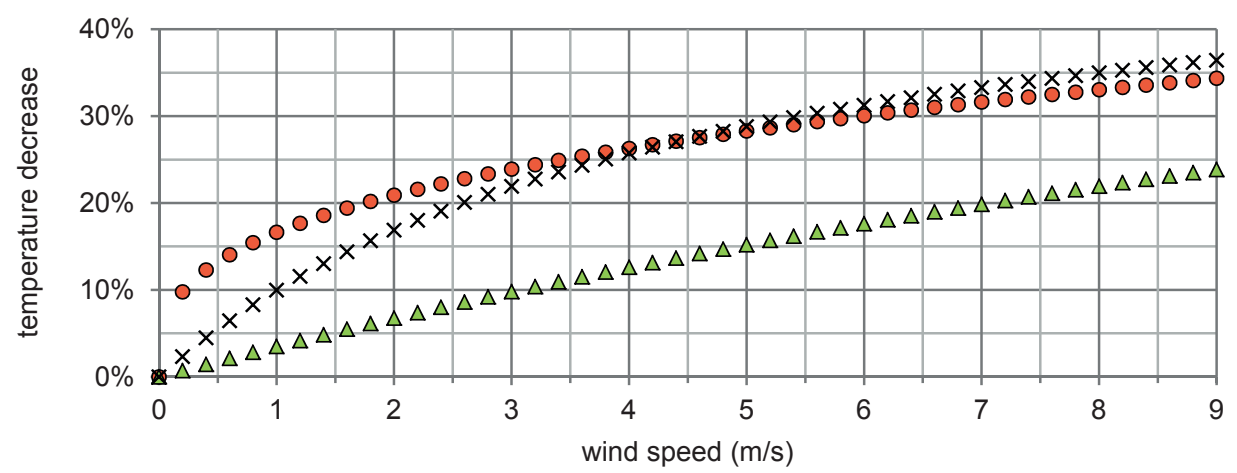

oNew $\quad \Delta$ King $\quad \times$ Skoplaki

Fig. 7.11. The temperature decrease due to the wind speed relative to the modeled PV module temperature without wind (i.e. $\mathrm{v}_{\mathrm{w}}=0$ ), for constant ambient temperature, relative humidity and irradiance of $30{ }^{\circ} \mathrm{C}, 70 \%$ and $1,000 \mathrm{~W} / \mathrm{m}^{2}$, respectively. 
From Fig. 7.11 it can be seen, that the cooling effect suggested by the proposed model is stronger at low wind speeds compared with the other models; however, the time lag of the proposed model should be taken into account as well. Therefore, the output response is presented in Fig. 7.12.

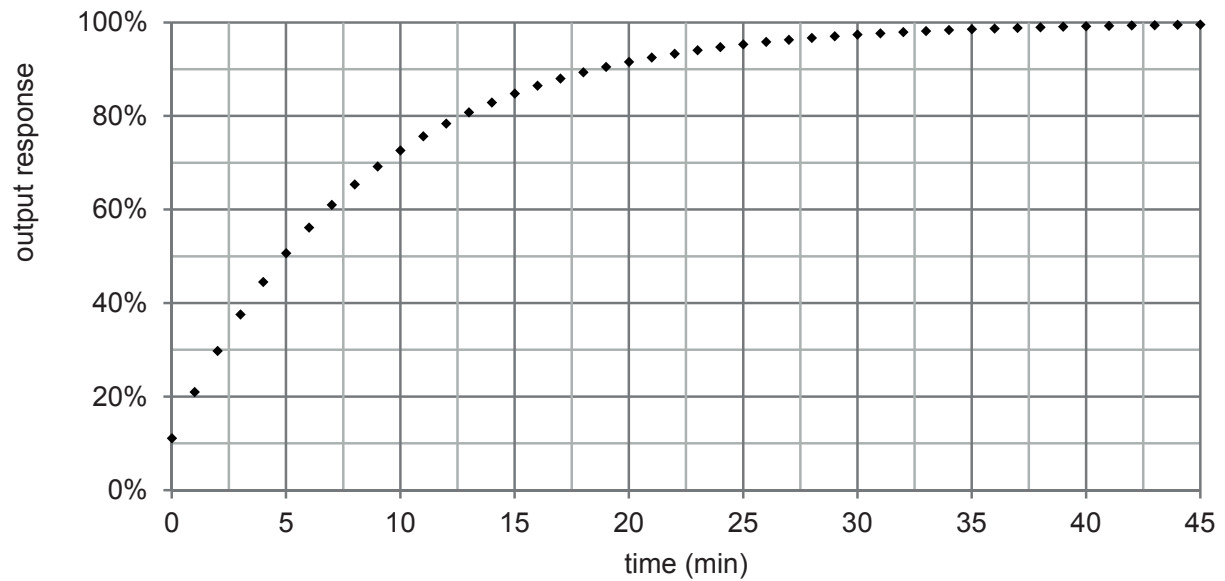

Fig. 7.12. The output response of the proposed model shows the time-dependent change in the modeled PV module temperature relative to the final step change caused by a change in one of the model parameters.

The output response of the proposed model shows the time it takes for the modeled PV module temperature to reach its final temperature after a step change in one of the input variables (i.e. ambient temperature, irradiance, wind speed or humidity). For example, based on the values shown in Fig. 7.11: If, after a windless period, a wind speed of $2 \mathrm{~m} / \mathrm{s}$ is measured, the Skoplaki and King's model will result in a direct decrease in PV module temperature of $17 \%$ and $7 \%$, respectively. For the proposed model, however, the immediate impact would only result in a $2 \%$ decrease $(11 \% \times 21 \%)$. If this wind speed stays constant, the modeled PV module temperature will have been decreased by $11 \%$ $(51 \% \times 21 \%)$ after $5 \mathrm{~min}$ and will finally approach a decrease of $21 \%$ after $40 \mathrm{~min}$.

In Fig. 7.13, the RMSEs of the measured vs. simulated PV module temperatures are shown for the different models, PV module technologies and locations for all irradiance levels during the day.

The proposed model performs best compared with the other evaluated models with an average RMSE of $1.6^{\circ} \mathrm{C}$ for all PV modules evaluated. On average, the accuracy has improved by $1.8{ }^{\circ} \mathrm{C}$ compared with the second best model of King et al. for all irradiance levels during the day. 


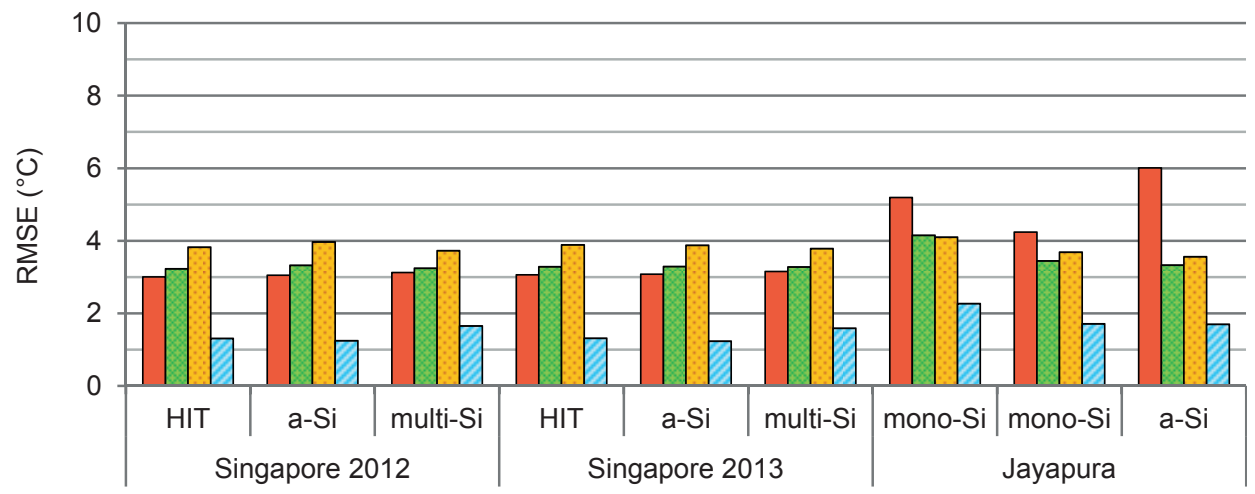

$\square$ Ross $\square$ King $\square$ Skop $\square$ New

Fig. 7.13. RMSE of the measured vs. simulated PV module temperature $\left({ }^{\circ} \mathrm{C}\right)$ for various PV modules and models.

In Fig. 7.14, the RMSEs of the measured vs. simulated PV module temperatures are shown for the different models, PV module technologies and locations for irradiance levels exceeding $500 \mathrm{~W} / \mathrm{m}^{2}$.

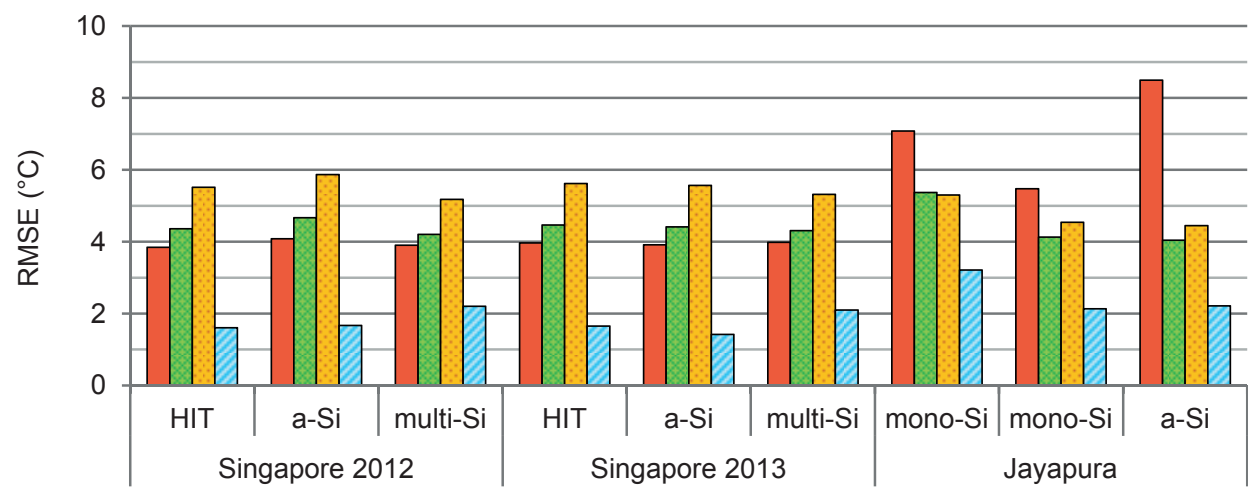

口Ross $\square$ King $\square$ Skop $\square$ New

Fig. 7.14. RMSE of the measured vs. simulated PV module temperature $\left({ }^{\circ} \mathrm{C}\right)$ for various PV modules and models for irradiance levels exceeding $500 \mathrm{~W} / \mathrm{m}^{2}$.

As can be seen in Fig. 7.14, the proposed model performs best compared with the other evaluated models. On average, the accuracy has improved by $2.4{ }^{\circ} \mathrm{C}$ compared with the second best model of King et al. for irradiance levels exceeding $500 \mathrm{~W} / \mathrm{m}^{2}$.

The RMSE of the temperatures of the mono-Si PV modules installed in Jayapura show some difference; the error of the first mono-Si PV module temperature is larger for each model, varying from $0.8-1.6{ }^{\circ} \mathrm{C}$. The maximum error based on the accuracy of the temperature sensors is $0.4{ }^{\circ} \mathrm{C}$, so this deviation cannot be explained by the inaccuracy of the 
measurements only. The first measured mono-Si PV module is closer to the wall and surrounded by other rack-mounted PV modules, whereas the second measured mono-Si PV module is in the front (first row, left rack in Fig. 5.4). This could result in a better ventilation of the second mono-Si PV module compared with the first one.

Furthermore, the Ross model produces slightly better results compared with the other existing models for the PV modules under monitoring in Singapore; however, the RMSE for the PV modules in Jayapura are significant higher. The chosen Ross coefficients for Singapore correspond quite well with the best fits, which vary between $0.023-0.026{ }^{\circ} \mathrm{C}$. $\mathrm{m}^{2} / \mathrm{W}$. For Jayapura, the Ross coefficients with the best fit have a much larger deviation from the selected ones. For the mono-crystalline PV modules in Jayapura a $k$ of $0.022{ }^{\circ} \mathrm{C}$. $\mathrm{m}^{2} / \mathrm{W}$ was assumed; however, the best fit was found with a $k$ of 0.027 and $0.030{ }^{\circ} \mathrm{C}$. $\mathrm{m}^{2} / \mathrm{W}$, corresponding to a RMSE of $3.8^{\circ} \mathrm{C}$ and $4.2^{\circ} \mathrm{C}$ for both PV modules, respectively. For the amorphous $\mathrm{PV}$ module, a $k$ of $0.017^{\circ} \mathrm{C} \cdot \mathrm{m}^{2} / \mathrm{W}$ was assumed, but the best fit was found for a $k$ of $0.027^{\circ} \mathrm{C} \cdot \mathrm{m}^{2} / \mathrm{W}$ corresponding to a RMSE of $3.8^{\circ} \mathrm{C}$. This confirms once more that it is difficult to select the right Ross coefficient for the situation at hand.

King's model produces consistently quite accurate results, with an average RMSE of 4.4 ${ }^{\circ} \mathrm{C}$. The model of Skoplaki performs less, with an average RMSE of $5.3^{\circ} \mathrm{C}$.

\subsection{Discussion of the proposed model}

The PV modules in Jayapura are installed on a walled roof; therefore, the measured wind speed at a height slightly above the wall is likely higher than the actual wind speed experienced by the PV modules. However, due to surrounding obstacles and turbulence, the exact wind speed experienced by PV modules is always hard to obtain.

A significant improvement has been made by determining the EMA over a certain time period to mimic the thermal inertia of the PV module. This temperature lag can easily be taken into account by the reference models as well. By taking the average over a certain number of minutely simulated PV module temperatures, the RMSE of these models can be reduced for the simulation on a minute scale. However, the best period to average over is found to vary considerably, ranging from $12-25 \mathrm{~min}$, depending on several factors, such as the temperature model, weather conditions and PV module.

One potential area for future work is on short term solar irradiance forecasting applications. As found in this study, an average time lag of $17 \mathrm{~min}$ represents that with varying irradiance conditions, module temperature variations would lag considerably. When short-term forecast horizons are taken into account (15-min and 30-min), lower or higher irradiance forecasts - which are primarily related to cloud cover - would not directly correlate with power output of PV systems, as the accuracy of the models could suffer due to thermal inertia of the PV modules.

Future studies could validate the model for other (tropical) locations as well, in order to know whether the model is suitable for a larger geographically area than studied here. 


\subsection{Conclusions}

A new model has been developed to simulate the short term PV module temperature for the Southeast Asian region. It is a simple empirical model, which requires minutely ambient temperature, incident irradiance, wind speed and $\mathrm{RH}$ as input variables to obtain the minutely PV module temperature.

The thermal inertia of the PV module is taken into account by calculating the EMA, which improves the accuracy during transient weather conditions.

The results show that the proposed model produces accurate results with RMSEs varying between $1.2-2.3^{\circ} \mathrm{C}$. Compared with the evaluated existing models, this model decreases the RMSE by $1.8{ }^{\circ} \mathrm{C}$ on average for all investigated PV modules in both locations compared with the second best model, which corresponds to an improvement of $46 \%$.

Since temperature effects play a larger role for higher irradiance levels, the model is evaluated separately for irradiance levels exceeding $500 \mathrm{~W} / \mathrm{m}^{2}$. Under these conditions, RMSEs are in the range of $1.4-3.2{ }^{\circ} \mathrm{C}$ for the different PV modules evaluated on both locations, which is an improvement of $2.4^{\circ} \mathrm{C}$ on average compared with the second best model, which also corresponding to an improvement of $46 \%$.

Best results are obtained for the a-Si and HIT modules in Singapore. Overall, the proposed model outperforms the other empirical models evaluated, making it a very suitable model to estimate the PV module temperature on a minute basis. 



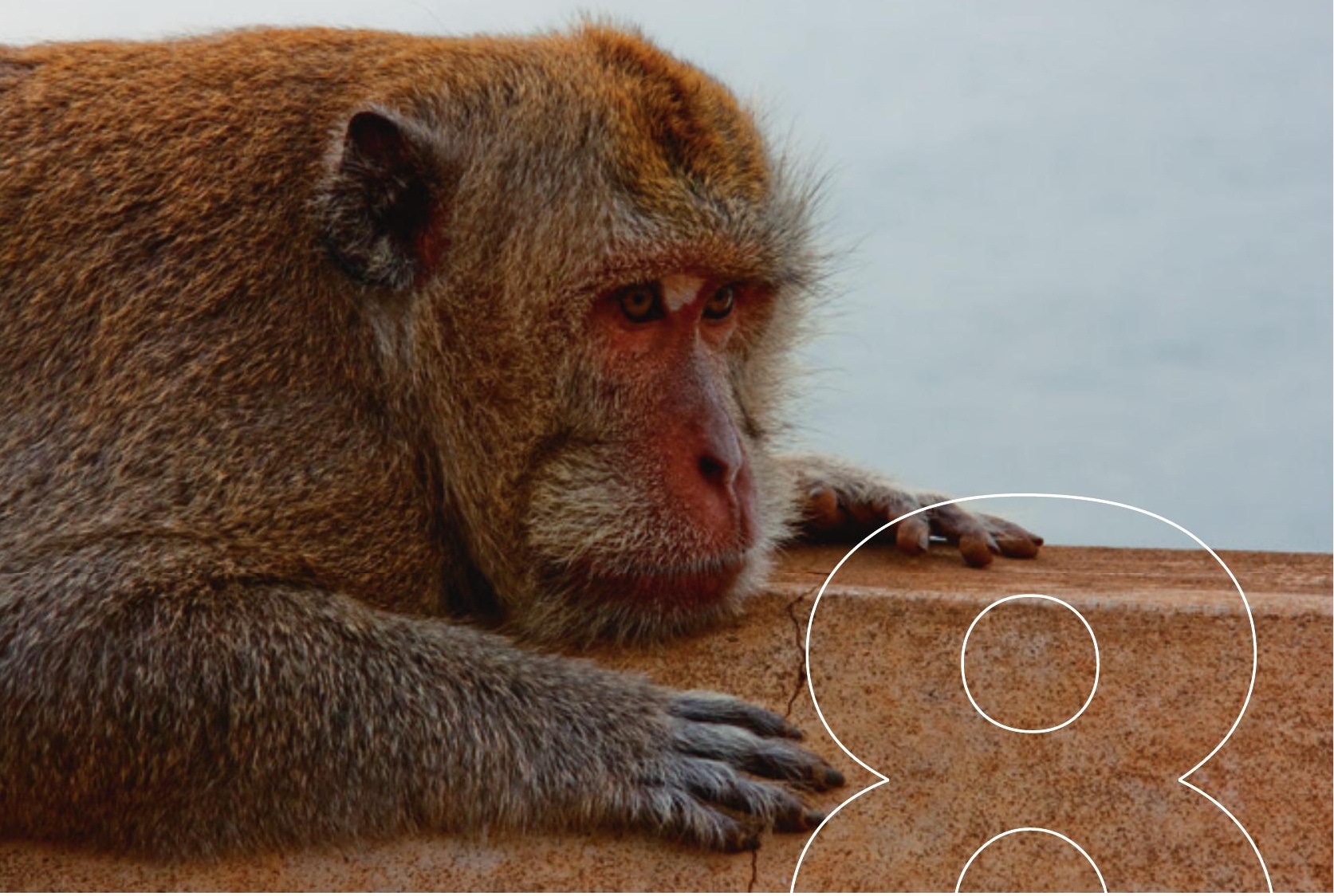

Reflection 


\section{8}

\section{Reflection}

In this chapter, I will reflect on the research described in this thesis. I will discuss the research approach, new developments during the research, problems during the study, limitations and the value of the obtained results.

\subsection{Macro-level: PV potential study}

This section reflects on the research presented in Chapter 3 and 4, which has a focus on the macro-level.

\subsubsection{Value}

Although the results of the PV potential models are sensitive to the various assumptions and some model relations are modeled simplistic, it is useful to get a better insight in the potential of PV systems. The models presented in Chapter 3 and 4 are intended to give a rough estimate of the potential and costs of PV systems and to show the differences among the different provinces. It shows that there are already many locations where experience with grid-connected PV systems could be obtained in a cost-effective manner. At least, this study at a macro-level can support discussions on energy planning in Indonesia, which is already an important step.

\subsubsection{Modeling approach}

Since the subsidized electricity prices are low, there is no financial incentive for individual consumers to install a PV system. Therefore, this study has been focused at the perspective of the state-owned electricity company PLN. When PV systems are cost-effective, PLN can save on the cost of fuel consumption for centralized electricity production. In the end, the Indonesian government will save on its fuel subsidies to PLN.

The population in the potential study is treated homogeneously, however in practice differences exist among others in income level and level of education. Although these social aspects can influence factors related to the potential for PV systems, such as the electricity demand, this would influence the actual potential only slightly. Since the total electricity demand per province remains the same, it would only influence the distribution of the electricity demand among the different areas. However, if the electricity subsidies would decrease in the future, these social aspects would get more important. When it will be 
financially more attractive for residential electricity consumers to invest in PV systems, the household income level and level of education influences the affordability and the knowledge to invest in PV systems.

The potential of PV systems in this study is related to the actual (grid-connected) population size and electricity demand. Both factors will likely increase and as such the potential of PV systems will.

\subsubsection{New developments}

During the research period developments continued. In the meantime the national electrification rate have been increased from $67 \%$ by the end of 2010 to around $80 \%$ by the end of 2013, more PV systems have been installed (currently installed capacity is 43 MW), a feed-in tariff (ceiling price of $0.25 \$ / \mathrm{kWh}$; $0.30 \$ / \mathrm{kWh}$ for projects with over $40 \%$ locally manufactured equipment) has been established, the PV module prices have decreased further and the national selling prices of fuel have been increased. These developments influence the actual potential of PV systems in a positive way.

\subsubsection{Limitations}

The study on grid-connected PV focuses on the macro-level, except for a minimal base load, limitations at the meso- or micro-level are not taken into account. At the meso-level one could think about the limitations set by the existing electricity distribution network which could influence the potential of grid-connected PV or the flexibility of existing central (fossil fuel) power plants which is advantageous for intermittent renewable energy resources. An example at the micro-level is the electricity load pattern of a household or local variations due to temperature or shadows.

Since detailed data on electricity load profiles were not available, it is assumed that all electricity generated by PV systems can be consumed, either by the direct user or by other consumers connected to the grid.

System sizing is based on average values such as irradiation and would therefore probably give a realistic value at the macro-level, however at the micro-level the system sizes would not have to be the most optimal. For this purpose other methodologies are more practical [140]. 


\subsection{Meso-level: Grid-connected PV system in Jayapura}

This section will reflect on the research presented in Chapter 5, which has a focus on the meso-level.

\subsubsection{Value}

The experience with the grid-connected PV system in Jayapura shows that such systems perform well in weak electricity grids in Indonesia. However, Indonesia is an enormous country, although it is located around the equator which limits the climatological differences within the country, differences exist. Jayapura is located in the most eastern province and could therefore experience another climate than more western provinces.

\subsubsection{Approach}

Based on the monitoring data the technical performance of the PV system in Jayapura has been evaluated. Another approach could be to study the social aspects, such as how the local people perceive PV systems or how people interact with the user information system of the inverters in case of failures. The monitoring data could have been used to inform the local community about the performance and energy yield of the PV system to attract them and inform them about PV systems.

Next to the technical energy losses, losses could occur due to the political instability in the region which can extend the period for maintenance engineers to visit the site.

\subsubsection{Limitations}

The research was carried out in practice, which made it possible to obtain realistic PV system performance values and supply useful electricity for the building appliances; however it also posed some limitations to the research. Regular checks of the PV and monitoring system were impossible due to the distance of the PV system in Jayapura. Besides, because a properly working internet connection was not available at the location of the monitoring system, real-time monitoring was not feasible and the monitoring data were sent manually instead. In addition, due to social unrest in Jayapura, there was a travel ban for roughly 1.5 years which delayed the final installation and maintenance operations.

Since only the total AC power of the Involar system has been measured, details about the reasons of the underperformance could not be studied.

Data on the performance of the local grid of PLN was not available; therefore it was not possible to study the exact reasons of the disconnected PV inverters.

Due to the limited PV system size relative to the electricity consumption of the building, only in the weekends there would be a chance that the generated electricity by PV would exceed the consumption. Therefore it was not attractive for PLN to modify the connection to allow feeding electricity back into the grid and for this reason it was not possible to study this. 


\subsection{Micro-level: Simulation of the PV power generation}

This section discusses the research which has been presented in Chapter 6 and 7. This research focuses on the micro-level.

\subsubsection{Value}

The simulation of PV systems can be helpful for PV system designers. Besides, simulations of PV systems can help to study underperforming PV systems during operation. To design better PV systems and to detect smaller failures of the PV system accurate PV system modeling is important. In this way these models and simulations can help to save energy and money. Besides, well-performing PV systems will increase the user experience which will facilitate a wider adoption of this technology.

An improved temperature model can add to the accuracy of the modeling. An improved accuracy for short-term power generation can be helpful when energy forecasting gets more important if more grid-connected PV gets installed in Indonesia. Although wind speeds are relatively low in Indonesia, the investigated PV module temperature models which included wind speed showed a better performance in general.

An exponential moving average for the PV module temperature is found to be a simple method to transform a steady-state model to an unsteady-state model, which requires less input variables than complex energy balance models.

Relative humidity is found to influence the PV module temperature slightly, however, when this is not measured on site, the temperature model of King et al. including an exponential moving average is proposed instead. The best time period to take the average over has to be investigated in more detail. It depends on several factors such as the model and the location of the PV modules, but a period of about 12 minutes will probably give reasonable values.

\subsubsection{Approach}

The simulations in Chapter 6 have been focused on the DC power generation of the PV modules. The simulations produce reasonable results, however for several months the errors became significant larger. The exact cause of this has not been studied in detail; a part could be related to the PV module temperature modeling implemented in the VR4PV which shows to influence the accuracy of the DC. The deviation in the simulated vs. measured results could be related to several factors, it could be caused by the modeling, the measurements or by anomalies of the PV system. Moreover, it could be that specific weather conditions related to the monsoon influences the PV system performance, which would be related to specific months.

Besides, it would be interesting to include the inverters in the modeling in order to be able to simulate and evaluate the $\mathrm{AC}$ power generation as well. 


\subsubsection{Limitations}

Since tilt angles in Indonesia are usually small, irradiance transposition models are less sensitive. Only one irradiance model is validated for only one PV system. Conclusions drawn upon this study are therefore limited. For a more thoroughly investigation of the various irradiance transposition models more extreme tilt angles would be advisable.

Since the exact I-V and P-V curves of the applied PV module are missing, the curves of another PV module from the same series but with a higher peak power has been used for the modeling of the PV module characteristics. The accurateness of the applied series and shunt resistance and the diode ideality factor were therefore not possible to verify. Since it had been found that the information on the datasheet of the PV modules is misleading, the supplied specifications cannot be taken for granted.

\subsection{General}

\subsubsection{Levels}

The research in this thesis has been focused on the three levels, the macro-, meso- and micro-level. It depends on the system boundaries or research scope which factors or components correspond to each level. A PV system can be perceived as a component at the micro-level while studying the potential at the macro-level. However, when the energy losses due to the PV module temperature are investigated, the PV module/cell corresponds to the micro-level and the PV system itself can be seen as a component at the macro-level.

\subsubsection{Design research}

In this thesis the focus has been mainly on the technical side of PV systems. Considering a PV system as an industrial product, other aspects are important to take into account as well. As stated in section 1.3, designers should focus on more than technology alone to create successful products. End-users, marketing, design \& styling and societal aspects play an important role for widespread adoption of PV systems as well.

The people in Indonesia should become familiar with the pros and cons of PV and obtain a realistic view of what can be achieved with PV systems. End-users in Indonesia have other experiences with and expectations of energy systems compared with end-users in more developed countries. For example, the frequent black-outs in several parts of Indonesia could make PV systems more attractive for the users. PV systems will create a more stable electricity supply and even if the PV system cannot produce enough electricity on some moments, the end-users are already more used to this situation. 



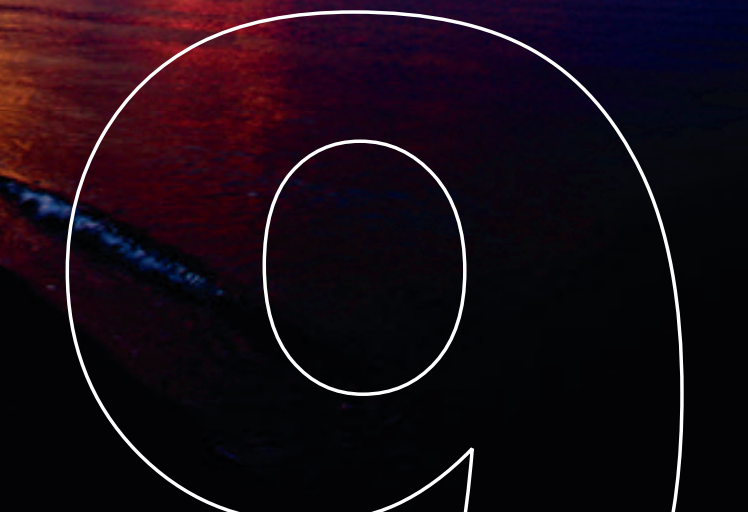

Conclusions and recommendations 


\section{9}

\section{Conclusions and recommendations}

The main objective of this thesis is to enhance the technical knowledge about PV systems in Indonesia. Based on the literature review presented in Chapter 2, it was found that the potential and cost-effectiveness of PV systems in Indonesia had not been fully explored. The experience with grid-connected PV systems in Indonesia was found to be limited, data on the performance of grid-connected PV systems inside weak grids in Indonesia was found to be practically non-existent. This was one of the reasons to install a grid-connected PV system in Jayapura, the capital of the province of Papua. Furthermore, existing models to simulate PV systems are mainly based on PV systems in Western countries which experience different climatological conditions; therefore some of these models have been evaluated for PV systems in Indonesia. The main findings of this research are:

- The potential of PV systems in Indonesia is huge and in large parts of Indonesia PV systems are cost-effective already.

- The grid-connected PV system studied in this thesis performs well. The performance is in line with other PV systems installed in other tropical and Western countries. The weak grid has an influence; however the energy losses related to grid instability are less than the energy losses due to the temperature.

- Models used in this thesis to simulate the power generation of the PV system under monitor, show that the models are appropriate to simulate the power output of PV systems in Indonesia.

- The modeling of the PV module temperature for small time scales has been improved, which can improve simulations of the PV power production.

The main findings are elaborated more in the next subsections.

\subsection{The potential and cost-effectiveness of PV systems}

For the assessment of the potential and cost of PV systems in Indonesia a distinction has been made between grid-connected and off-grid. For both PV system configurations a mathematical model has been developed based on publicly available statistics and figures found in literature. Since large geographic differences exist in Indonesia, the evaluation has 
been carried out at a provincial level. Due to restrictions set by the availability of data, this evaluation has been based on data from the year 2010 .

\subsubsection{Grid-connected PV}

The total technical potential is determined by taking the grid-connected area, land availability factors, performance ratio of the PV systems and efficiency of the PV modules into account. Four kinds of areas are distinguished: urban cores, suburban areas, gridconnected rural villages and off-grid rural areas. The total technical potential of gridconnected PV in Indonesia is estimated to be roughly $1,100 \mathrm{GW}_{\mathrm{p}}$, generating about 1,492 TWh which is 10 times more than the electricity consumed in Indonesia in 2010.

Taking constraints of the present electricity demand during day-time and a minimal base load of conventional power systems into account, then the total potential is about $28 \mathrm{GW}_{\mathrm{p}}$, generating $37 \mathrm{TWh} /$ year, which is about $25 \%$ of the total electricity consumption in Indonesia in 2010.

Compared with the energy potentials of other renewables in Indonesia, the present potential of grid-connected PV is similar to the potential of geothermal energy and roughly the half of the potential for biomass.

Also the LCOE of grid-connected PV has been estimated for each area in each province. The LCOE for all provinces range from 0.15 to $0.22 \$ / \mathrm{kWh}$ for urban areas and from 0.17 to $0.24 \$ / \mathrm{kWh}$ for grid-connected rural villages.

Based on the assumed system price of $4 \$ / \mathrm{W}_{\mathrm{p}}$, PV cannot compete yet with the retail prices of electricity which are subsidized by the government. However, in some provinces, especially located in the eastern part of Indonesia, the LCOE of grid-connected PV is already cost-effective.

Nevertheless with the feed-in tariff for PV energy, expected decline of PV system costs and projected increase of fossil fuel cost, grid-connected PV gets cost-effective in most parts of Indonesia.

According to the sensitivity analysis, the major factors of influence on the LCOE are the system price and the discount rate. It is shown that with a system price of $2 \$ / W_{\mathrm{p}} \mathrm{PV}$ systems are cost-effective for large parts of Indonesia. At $0.80 \$ / \mathrm{W}_{\mathrm{p}}$ grid-parity has reached in all provinces, while assuming that all other variables remain constant.

Grid-connected PV could play a key role in solving several energy related issues in Indonesia. It can help to increase electrification rates on remote islands and to decrease the dependency on fossil fuels.

\subsubsection{Off-grid PV}

The evaluation of the potential of off-grid PV systems focuses on the population living in rural areas which lack access to electricity. Two configurations for off-grid PV systems are evaluated: a hybrid PV system with battery and diesel generator inside a local grid, and a 
standalone PV system with battery. Since a local grid requires a certain population density in order to be economically feasible, the population density distribution in these rural areas has been modeled as well.

The technical potential of off-grid PV systems is estimated to be $969 \mathrm{GWh} /$ year, of which $566 \mathrm{GWh} /$ year generated inside local grids (PV-battery-diesel) and $403 \mathrm{GWh} /$ year in the form of stand-alone PV systems (PV-battery). A total nominal power of $816 \mathrm{MW}_{\mathrm{P}}$ PV systems, $321 \mathrm{MW}$ diesel gensets and $8.5 \mathrm{GWh}$ battery capacities is estimated to be required to achieve $100 \%$ electrification in rural areas. This total capacity of off-grid PV corresponds to just $3 \%$ of the grid-connected PV potential of $28 \mathrm{GW}_{\mathrm{p}}$.

In most rural parts of Indonesia the LCOE of off-grid PV systems is lower compared with the electricity generation based on diesel gensets with unsubsidized fuel costs. Especially, the hybrid PV configuration - with on average a LCOE of $0.38 \$ / \mathrm{kWh}$ - shows a significant lower LCOE compared with the diesel generated electricity for all provinces. The LCOE of electricity of the stand-alone PV configuration, which is on average 0.76 $\$ / \mathrm{kWh}$, is lower in 25 of the 32 provinces $^{24}$ of Indonesia. Eight of these provinces show a LCOE which is at least $0.05 \$ / \mathrm{kWh}$ cheaper, including the two with the highest share of households without access to electricity - East Nusa Tenggara and Papua. Besides, in 13 of the 32 provinces the LCOE is only $\pm 0.01 \$ / \mathrm{kWh}$ cheaper (eight provinces) or costlier (five provinces) than electricity generated by diesel, indicating that PV systems are on the edge of becoming cost-effective on large scale. Since it is expected that fuel prices will increase and PV systems will become cheaper, it is expected that this difference in LCOE will change in favor of the PV systems, so that the PV systems will become cost-effective in all rural areas.

To electrify all rural areas in Indonesia by the combination of the proposed hybrid PV micro-grids and stand-alone PV systems, the total cost over 25 years is estimated to be roughly 13 billion US dollars.

The hybrid PV system shows the lowest LCOE with the smallest deviation based on the sensitivity analysis, but requires a certain population density in order to be feasible. Compared with the LCOE of grid-connected PV for rural areas ranging from 0.15 to 0.24 $\$ / \mathrm{kWh}$, off-grid PV systems are significant more expensive.

Overall, PV systems are cost-effective in large rural parts in Indonesia already and it is highly likely that this will become the case for all rural areas of Indonesia in the coming years. At the same time, in regions where PV systems are already cost-effective, they will become financially more attractive.

\footnotetext{
${ }^{24}$ Excluding the province of Jakarta, which lacks rural areas
} 


\subsection{The performance of the PV system in Jayapura}

In Jayapura a $34 \mathrm{~kW}_{\mathrm{p}}$ grid-connected PV system has been installed. This PV system consists of four PV arrays: Two $12 \mathrm{~kW}_{\mathrm{p}}$ PV arrays of mono-crystalline silicon PV modules, one $7.2 \mathrm{~kW}_{\mathrm{p}}$ PV array of amorphous silicon PV modules and the last PV array consists of twelve mono-crystalline silicon PV modules, each connected to a micro-inverter.

When the PV system is online, it performs well with PRs around $80 \%$ for both $12 \mathrm{~kW}_{\mathrm{P}}$ arrays and about $90 \%$ for the 7.2 PV array. The micro-inverters perform significantly less with an average PR of 57\%, they experience faulty behavior, however the exact cause could not be determined. Overall, it is found that the performances are in line with other PV systems in tropical areas.

The energy losses of the PV system have been determined. Due to the weak grid conditions, the PV system is on average $2.4 \%$ of the time offline, with estimated energy losses of 1.8 MWh, another 1.6 MWh is lost due to system faults and 3.4 MWh is lost due to the temperature effect. Relative to the $43.0 \mathrm{MWh}$ of total electricity generated from May 2013 - April 2014, these losses are 4.1\%, 3.8\% and 7.9\%, respectively. The energy losses associated with grid instability are thus in the same range of the energy losses caused by faulty system behavior and are roughly the half of the energy losses related to the PV modules temperature.

The total estimated energy losses are 6.8 MWh, which is $16 \%$ of the total electricity production during the investigated period.

\subsection{Simulation of the power generation of PV systems}

To simulate the power output of the PV system in Jayapura the VR4PV tool is applied. It is a software tool developed to assess the power output of PV modules in a virtual reality (VR) environment.

The simulation of the power generation of the PV system in Jayapura has been evaluated for two datasets. One is based on the measured weather variables on site; the other simulation is based on publically available weather data of climatological stations in the area. The former is evaluated at a minutely time scale, the latter at an hourly time scale.

The simulation based on minutely measured global horizontal irradiance produces reasonable values for the DC power output. The monthly average RMSE is found to be in the range of $350-740 \mathrm{~W}$ for a PV array of $12 \mathrm{~kW}_{\mathrm{p}}$, corresponding to respectively $7 \%$ and 18\% of the monthly average DC power output for the period May 2013 - April 2014.

The minutely simulated PV module temperature shows a RMSE of roughly $4{ }^{\circ} \mathrm{C}$, corresponding to $10 \%$ of the average measured PV module temperature. With a temperature coefficient for the maximum power of $-0.42 \% /{ }^{\circ} \mathrm{C}$, this corresponds to an average error of around $2 \%$ of the power output. 
The hourly simulation of the DC power output based on publicly available irradiance data shows less accurate results. The average RMSE is found to be about $2.3 \mathrm{~kW}$ for the 12 $\mathrm{kW}_{\mathrm{p}} \mathrm{PV}$ array, corresponding to $55 \%$ relative to the average measured DC power output for the period from May 2013 - April 2014.

Although the publicly available weather data are measured at a distance too far away from the PV system site in Jayapura to simulate the hourly power output accurately, these data can be used to determine the total monthly electricity production. Based on hourly measurements covering a year, the relative error is found to be $-2 \%$ of the total measured electricity production. Evaluations per month show a relative error varying between $-16 \%-$ $11 \%$ of the total monthly measured electricity production.

Overall, the RMSE shows fairly low values at medium to high irradiance levels which shows that the underlying irradiance and temperature models which are implemented in the VR4PV are appropriate to simulate the power output of PV systems in Indonesia.

\subsection{PV temperature modeling}

Since temperature effects regarding the power output of PV systems play a large role in tropical areas such as Indonesia, the modeling of the PV module temperature has been evaluated. A new model has been proposed to simulate the short term PV module temperature for the Southeast Asian region. It is a simple empirical model which requires minutely ambient temperature, incident irradiance, wind speed and relative humidity as input variables to obtain the minutely PV module temperature.

The thermal inertia of the PV module is taken into account by calculating the exponential moving average, which improves the accuracy during transient weather conditions.

The model is validated for various PV modules in Jayapura and in Singapore and the results are compared with three existing empirical models.

The results show that the proposed model produces accurate results with RMSEs varying between $1.2-2.3{ }^{\circ} \mathrm{C}$. Compared with the evaluated existing models, this model decreases the RMSE by $1.8{ }^{\circ} \mathrm{C}$ on average for all investigated PV modules in both locations compared with the second best model, which corresponds to an improvement of $46 \%$.

Since temperature effects play a larger role for higher irradiance levels, the model is evaluated separately for irradiance levels exceeding $500 \mathrm{~W} / \mathrm{m}^{2}$. Under these conditions RMSEs are in the range of $1.4-3.2{ }^{\circ} \mathrm{C}$ for the different PV modules evaluated on both locations, which is an improvement of $2.4^{\circ} \mathrm{C}$ on average compared with the second best model, also corresponding to an improvement of $46 \%$.

Best results are obtained for the a-Si and HIT modules in Singapore. Overall, the proposed model outperforms the other empirical models evaluated, making it a very suitable model to estimate the PV module temperature on a minute basis. 


\subsection{Directions for future research}

\subsubsection{PV potential mapping}

In off-grid situations, micro-hydro systems are able to supply electricity cheaper than PV systems in areas where the resource potential is sufficient. By including the potential of micro-hydro, the locations in which PV is the most attractive solution can be determined at a higher resolution. Besides, local variations inside the province, which have been neglected in this thesis, can be included in order to generate more detailed maps. For these more detailed maps geographic information systems (GIS) are more suitable.

When fuel subsidies will decrease in the future, PV systems get more attractive for consumers to invest in. For this reason it would be good to include social aspects of the population as well, such as income level and level of education. In this way it is possible to forecast where it is most likely that PV systems will be installed and what its potential will be. Besides, a growth in grid-connected PV systems can have an impact on the local grid characteristics, which can be important for utilities to know beforehand.

\subsubsection{Performance of grid-connected PV systems}

Future research could install and monitor more grid-connected PV systems across Indonesia in order to draw broader conclusions on the performance and lifetime costs of such PV systems in Indonesia.

Besides, it would be interesting to know the long-term performance of grid-connected PV in Indonesia. The grid quality could impact the lifetime of the various components, which would influence the LCOE.

\subsubsection{Simulation procedures}

The isotropic model applied to determine the irradiance in plane is a relatively simple model. More advanced models, such as the Perez model, could be validated to see whether this improves the accuracy of the simulated irradiance.

The newly proposed temperature model could be implemented in the VR4PV tool in order to evaluate whether this improves the accuracy of the simulated power generation at small time scales.

The number of (publicly) available irradiance sensors is quite limited for the enormous distances Indonesia comprises [141]. For more detailed potential mapping of PV systems, increased accurateness of PV power simulations and PV power forecasting more meteorological stations should be installed and distributed over Indonesia.

\subsubsection{General}

The potential of grid-connected PV systems is significant larger than off-grid PV systems. Besides, it is expected that the trend of urbanization will continue in Indonesia, therefore this potential of grid-connected PV systems will grow. Since grid-connected PV systems 
can play an important role in several energy related issues in Indonesia and they are already cost-effective in parts of Indonesia, hence it is recommended to pay more attention to gridconnected PV systems.

A specific area of interest for Indonesia would be the use of grid-connected PV systems to improve the quality of the grid in urban areas.

One of the limiting factors of PV systems in general, which is specifically important for Indonesia, is the need of storage of electricity to be able to balance supply and demand of electricity. In highly developed areas, the electricity grid could act as a storage mechanism and the larger the grid the easier it is to achieve this in an efficient manner, however since Indonesia comprises many islands, most grids - if a grid exists in the first place - are relatively small. So, research on renewable energy technologies which includes an energy storage mechanism should be promoted in order to obtain experience with these systems and to be able to improve them in a design context. 


\section{Bibliography}

[1] F. U. Ermawati, "Photovoltaic in Indonesia Research, Projects and Market Possibilities," in 38th Annual Conference of the Australian and New Zealand Solar Energy Society Brisbane, Australia, 2000, pp. 446-454.

[2] A. S. Dasuki, M. Djamin, and A. Y. Lubis, "The strategy of photovoltaic technology development in Indonesia," Renewable Energy, vol. 22, pp. 321-326, 2001.

[3] N. Adra, B. Reuze, and A. Suradjat, "Reinforcing provision of sustainable ENergy services in Bangladesh and Indonesia for Poverty alleviation and sustainable DEVelopment," Intelligent Energy - Europe, 2009.

[4] A. Sudradjat, "Indonesian effort to better quality of Solar Home System," in Photovoltaic Specialists Conference, 2002. Conference Record of the Twenty-Ninth IEEE, 2002, pp. 14891492.

[5] F. Nieuwenhout, A. Van Dijk, P. Lasschuit, G. Van Roekel, V. Van Dijk, D. Hirsch, H. Arriaza, M. Hankins, B. Sharma, and H. Wade, "Experience with solar home systems in developing countries: a review," Progress in Photovoltaics: Research and Applications, vol. 9, pp. 455-474, 2001.

[6] Ministry of Energy and Mineral Resources, "Solar Energy in Indonesia: Potentials, Plannings and Framework Conditions," ed. Berlin, 2012.

[7] EPIA, "Unlocking the Sunbelt Potential of Photovoltaics," European Photovoltaic Industry Association (EPIA), Brussels, 2011.

[8] M. Jayawardena, "Electricity for all : options for increasing access in Indonesia," World Bank, Washington DC, 2005.

[9] A. Cabraal, M. Cosgrove-Davies, and L. Schaeffer, "Best practices for photovoltaic household electrification programs," in Photovoltaic Specialists Conference, 1996., Conference Record of the Twenty Fifth IEEE, 1996, pp. 1357-1362.

[10] N. Phuangpornpitak and S. Kumar, "User acceptance of diesel/PV hybrid system in an island community," Renewable Energy, vol. 36, pp. 125-131, 2011.

[11] R. Schleicher-Tappeser, "How renewables will change electricity markets in the next five years," Energy Policy, vol. 48, pp. 64-75, 2012.

[12] M. A. Eltawil and Z. Zhao, "Grid-connected photovoltaic power systems: Technical and potential problems-A review," Renewable and Sustainable Energy Reviews, vol. 14, pp. 112 129, 2010.

[13] E. Caamaño-Martín, H. Laukamp, M. Jantsch, T. Erge, J. Thornycroft, H. De Moor, S. Cobben, D. Suna, and B. Gaiddon, "Interaction between photovoltaic distributed generation and electricity networks," Progress in Photovoltaics: Research and Applications, vol. 16, pp. 629643, 2008.

[14] D. P. Kaundinya, P. Balachandra, and N. H. Ravindranath, "Grid-connected versus standalone energy systems for decentralized power-A review of literature," Renewable and Sustainable Energy Reviews, vol. 13, pp. 2041-2050, 2009.

[15] N. J. Schenk, H. C. Moll, and A. J. Schoot Uiterkamp, "Meso-level analysis, the missing link in energy strategies," Energy Policy, vol. 35, pp. 1505-1516, 2007.

[16] M. Grubb, J. Edmonds, P. Ten Brink, and M. Morrison, "The costs of limiting fossil-fuel CO2 emissions: a survey and analysis," Annual Review of Energy and the environment, vol. 18, pp. 397-478, 1993. 
[17] A. Collins, D. Joseph, and K. Bielaczyc, "Design research: Theoretical and methodological issues," The Journal of the learning sciences, vol. 13, pp. 15-42, 2004.

[18] A. H. Reinders, J. C. Diehl, and H. Brezet, The Power of Design: Product Innovation in Sustainable Energy Technologies: Wiley, 2012.

[19] J. Brown and L. Peskett, "Climate finance in Indonesia - lessons for the future of public finance for climate change mitigation. ," EDC2020 Working Paper 112011.

[20] H. Najamuddin, "Future Outlook PLN's Coal Fired Power Plant," PLN, Presentation2012.

[21] N. Gunningham, "Managing the energy trilemma: The case of Indonesia," Energy Policy, vol. 54, pp. 184-193, 2013.

[22] M. H. Hasan, W. K. Muzammil, T. M. I. Mahlia, A. Jannifar, and I. Hasanuddin, "A review on the pattern of electricity generation and emission in Indonesia from 1987 to 2009," Renewable and Sustainable Energy Reviews, vol. 16, pp. 3206-3219, 2012.

[23] U.S. Energy Information Administration. International Energy Statistics [Online]. Available: http://www.eia.gov/cfapps/ipdbproject/iedindex3.cfm?tid=90\&pid=44\&aid=8

[24] BPS. Population Census Data - Statistics Indonesia [Online].

[25] PT PLN, "PLN STATISTICS 2010," ed. Jakarta: PLN, 2011.

[26] P. Vithayasrichareon, I. F. MacGill, and T. Nakawiro, "Assessing the sustainability challenges for electricity industries in ASEAN newly industrialising countries," Renewable and Sustainable Energy Reviews, vol. 16, pp. 2217-2233, 2012.

[27] I. H. Rehman, A. Kar, M. Banerjee, P. Kumar, M. Shardul, J. Mohanty, and I. Hossain, "Understanding the political economy and key drivers of energy access in addressing national energy access priorities and policies," Energy Policy, vol. 47, Supplement 1, pp. 27-37, 2012.

[28] M. H. Hasan, T. M. I. Mahlia, and H. Nur, "A review on energy scenario and sustainable energy in Indonesia," Renewable and Sustainable Energy Reviews, vol. 16, pp. 2316-2328, 2012.

[29] Austrade, "Trade opportunities: low emissions technology and services to Indonesia," 2012.

[30] Ministry of Energy and Mineral Resources. (2010). Photovoltaic Solar Energy Utilization in Indonesia. Available: http://www.esdm.go.id/index-en/54-articles/3355-photovoltaic-solarenergy-utilization-in-indonesia.html

[31] BPS, "Trends of selected socio-economic indicators of Indonesia," February 20122012.

[32] Ministry of Energy and Mineral Resources, "Handbook of energy and economic statistic of Indonesia," 2010.

[33] Ministry of Energy and Mineral Resources, "Blueprint of National Energy Management 2006 2025," Government of Indonesia, Jakarta, 2006.

[34] IISD, "Indonesia's Fuel Subsidies: Action plan for reform," GSI, 2012.

[35] D. Dapice and E. A. Cunningham, "Squaring the Circle: Politics and Energy Supply in Indonesia," Havard Kennedy School ASH center, 2011.

[36] N. U. Blum, R. Sryantoro Wakeling, and T. S. Schmidt, "Rural electrification through village grids-Assessing the cost competitiveness of isolated renewable energy technologies in Indonesia," Renewable and Sustainable Energy Reviews, vol. 22, pp. 482-496, 2013.

[37] PLN, "Investor Presentation," 2013.

[38] A. T. Winoto, E. D. Marliska, M. H. Prasetyo, and S. Simangunsong, "Rural Electrification in Indonesia Target and Development," MEMR, Ed., ed: Republic of Indonesia, 2012.

[39] International Institute for Sustainable Development, "A Citizens' Guide to Energy Subsidies in Indonesia: 2012 Update," International Institute for Sustainable Development, 2012.

[40] H. D. Matthews, T. L. Graham, S. Keverian, C. Lamontagne, D. Seto, and T. J. Smith, "National contributions to observed global warming," Environmental Research Letters, vol. 9, p. 014010, 2014.

[41] H. Hondo, "Life cycle GHG emission analysis of power generation systems: Japanese case," Energy, vol. 30, pp. 2042-2056, 2005. 
[42] M. R. Karlsdottir, O. P. Palsson, and H. Palsson, "Factors for Primary Energy Efficiency and CO2 Emission of Geothermal Power Production," power, vol. 2, p. 16, 2010.

[43] V. M. Fthenakis, H. C. Kim, and E. Alsema, "Emissions from Photovoltaic Life Cycles," Environmental Science \& Technology, vol. 42, pp. 2168-2174, 2008.

[44] I. B. Fridleifsson, "Geothermal energy for the benefit of the people," Renewable and Sustainable Energy Reviews, vol. 5, pp. 299-312, 2001.

[45] V. M. Fthenakis and H. C. Kim, "Greenhouse-gas emissions from solar electric- and nuclear power: A life-cycle study," Energy Policy, vol. 35, pp. 2549-2557, 2007.

[46] D. Weisser, "A guide to life-cycle greenhouse gas (GHG) emissions from electric supply technologies," Energy, vol. 32, pp. 1543-1559, 2007.

[47] A. Widiyanto, S. Kato, and N. Maruyama, "Environmental impact analysis of Indonesian electric generation systems (development of a life cycle inventory of Indonesian electricity)," JSME International Journal Series B, vol. 46, pp. 650-659, 2003.

[48] E. Alsema, M. de Wild-Scholten, and V. Fthenakis, "Environmental impacts of PV electricity generation-a critical comparison of energy supply options," in 21st European photovoltaic solar energy conference, Dresden, Germany, 2006.

[49] E. Alsema, "Energy pay-back time and CO2 emissions of PV systems," Progress in Photovoltaics: Research and Applications, vol. 8, pp. 17-25, 2000.

[50] R. García-Valverde, C. Miguel, R. Martínez-Béjar, and A. Urbina, "Life cycle assessment study of a $4.2 \mathrm{kWp}$ stand-alone photovoltaic system," Solar Energy, vol. 83, pp. 1434-1445, 2009.

[51] M. Canakci and J. H. Van Gerpen, "Comparison of engine performance and emissions for petroleum diesel fuel, yellow grease biodiesel, and soybean oil biodiesel," Transactions of the $A S A E$, vol. 46, pp. 937-944, 2003.

[52] A. Chaurey and T. C. Kandpal, "Carbon abatement potential of solar home systems in India and their cost reduction due to carbon finance," Energy Policy, vol. 37, pp. 115-125, 2009.

[53] A. Evans, V. Strezov, and T. J. Evans, "Assessment of sustainability indicators for renewable energy technologies," Renewable and Sustainable Energy Reviews, vol. 13, pp. 1082-1088, 2009.

[54] E. A. Alsema, "Energy requirements and CO2 mitigation potential of PV systems," 1998.

[55] A. H. Kuncoro, "Renewable Energy for Power Generation in Indonesia," 2011.

[56] IEA, "Energy Policy Review of Indonesia," 2008.

[57] PWC, "Electricity in Indonesia - Investment and Taxation Guide," PWC, 2011.

[58] W. W. Purwanto, Y. S. Nugroho, R. Dalimi, H. Soepardjo, A. Wahid, D. Supramono, D. Herminna, and T. A. Adilina, "Indonesia energy outlook \& statistics 2006," 2006.

[59] C. R. Chamorro, M. E. Mondéjar, R. Ramos, J. J. Segovia, M. C. Martín, and M. A. Villamañán, "World geothermal power production status: Energy, environmental and economic study of high enthalpy technologies," Energy, vol. 42, pp. 10-18, 2012.

[60] F. Ardiansyah, N. Gunningham, and P. Drahos, "An environmental perspective on energy development in Indonesia," in Energy and non-traditional security (NTS) in Asia, ed: Springer, 2012, pp. 89-117.

[61] IEA, "IEA PVPS Task III Stand-alone PV systems," 1999.

[62] Developing Renewables, "Renewable energy potential - Country report Indonesia," 2006.

[63] Ministry of Energy and Mineral Resources. (2010). Indonesian Solar Energy Utilization. Available: utilization.html

[64] NASA. Atmospheric Science Data Center [Online]. Available: http://eosweb.larc.nasa.gov/sse/

[65] Time and Date AS. (2014). timeanddate.com. Available: http://www.timeanddate.com/

[66] R. B. Hiremath, S. Shikha, and N. H. Ravindranath, "Decentralized energy planning; modeling and application-a review," Renewable and Sustainable Energy Reviews, vol. 11, pp. 729-752, 2007. 
[67] L. G. Swan and V. I. Ugursal, "Modeling of end-use energy consumption in the residential sector: A review of modeling techniques," Renewable and Sustainable Energy Reviews, vol. 13, pp. 1819-1835, 2009.

[68] V. Daioglou, B. J. van Ruijven, and D. P. van Vuuren, "Model projections for household energy use in developing countries," Energy, vol. 37, pp. 601-615, 2012.

[69] B. J. van Ruijven, D. P. van Vuuren, B. J. de Vries, M. Isaac, J. P. van der Sluijs, P. L. Lucas, and P. Balachandra, "Model projections for household energy use in India," Energy Policy, vol. 39, pp. 7747-7761, 2011.

[70] C. Breyer, "Identifying off-grid Diesel-Grids on a global scale for economic advantageous upgrading with PV and wind power," in 5th Alliance for Rural Electrification Workshop on Joint research activities between the academia and the industry: bringing new opportunities to the renewables sector, Frankfurt, September, 2012.

[71] S. Szabo, K. Bodis, T. Huld, and M. Moner-Girona, "Energy solutions in rural Africa: mapping electrification costs of distributed solar and diesel generation versus grid extension," Environmental Research Letters, vol. 6, p. 034002, 2011.

[72] S. Szabó, K. Bódis, T. Huld, and M. Moner-Girona, "Sustainable energy planning: Leapfrogging the energy poverty gap in Africa," Renewable and Sustainable Energy Reviews, vol. 28, pp. 500-509, 2013.

[73] B. J. van Ruijven, J. Schers, and D. P. van Vuuren, "Model-based scenarios for rural electrification in developing countries," Energy, vol. 38, pp. 386-397, 2012.

[74] International Electrotechnical Commission, "Photovoltaic (PV) module performance testing and energy rating - Part 1: Irradiance and temperature performance measurements and power rating," vol. IEC 61853-1 ed1.0, ed, 2011.

[75] U. Jahn and W. Nasse, "Operational performance of grid-connected PV systems on buildings in Germany," Progress in Photovoltaics: Research and Applications, vol. 12, pp. 441-448, 2004.

[76] N. H. Reich, B. Mueller, A. Armbruster, W. G. J. H. M. van Sark, K. Kiefer, and C. Reise, "Performance ratio revisited: is PR $>90 \%$ realistic?," Progress in Photovoltaics: Research and Applications, vol. 20, pp. 717-726, 2012.

[77] A. Reinders, A. Sudradjat, V. Van Dijk, R. Mulyadi, and W. Turkenburg, "Sukatani revisited: on the performance of nine-year-old solar home systems and street lighting systems in Indonesia," Renewable and Sustainable Energy Reviews, vol. 3, pp. 1-47, 1999.

[78] A. J. Aristizábal and G. Gordillo, "Performance monitoring results of the first grid-connected BIPV system in Colombia," Renewable Energy, vol. 33, pp. 2475-2484, 2008.

[79] G. Blaesser, "Guidelines for the assesment of photovoltaic plants: Document A: photovoltaic system monitoring," 1993.

[80] C. W. A. Baltus, E. A. Alsema, A. Reinders, J. Boumans, R. J. C. v. Zolingen, and B. C. Middelman, "Aanbevolen werkwijze voor de monitoring van netgekoppelde PV-systemen in Nederland, uitgave 02," 1997.

[81] B. Y. Liu and R. C. Jordan, "The interrelationship and characteristic distribution of direct, diffuse and total solar radiation," Solar Energy, vol. 4, pp. 1-19, 1960.

[82] R. Perez, R. Seals, P. Ineichen, R. Stewart, and D. Menicucci, "A new simplified version of the perez diffuse irradiance model for tilted surfaces," Solar Energy, vol. 39, pp. 221-231, 1987.

[83] D. L. King, W. E. Boyson, and J. A. Kratochvill, "Photovoltaic Array Performance Model," Sandia National Laboratories SAND2004-3535, 2004.

[84] E. Skoplaki and J. A. Palyvos, "On the temperature dependence of photovoltaic module electrical performance: A review of efficiency/power correlations," Solar Energy, vol. 83, pp. 614-624, 2009. 
[85] D. Sera, R. Teodorescu, and P. Rodriguez, "PV panel model based on datasheet values," in Industrial Electronics, 2007. ISIE 2007. IEEE International Symposium on, 2007, pp. 23922396.

[86] H. Patel and V. Agarwal, "MATLAB-based modeling to study the effects of partial shading on PV array characteristics," Energy Conversion, IEEE Transactions on, vol. 23, pp. 302-310, 2008.

[87] M. G. Villalva and J. R. Gazoli, "Comprehensive approach to modeling and simulation of photovoltaic arrays," Power Electronics, IEEE Transactions on, vol. 24, pp. 1198-1208, 2009.

[88] D. Connolly, H. Lund, B. V. Mathiesen, and M. Leahy, "A review of computer tools for analysing the integration of renewable energy into various energy systems," Applied Energy, vol. 87, pp. 1059-1082, 2010.

[89] International Energy Agency, "World-wide overview of design and simulation tools for hybrid PV systems," IEA-PVPS T11-01:2011, 2011.

[90] J. L. Bernal-Agustín and R. Dufo-López, "Simulation and optimization of stand-alone hybrid renewable energy systems," Renewable and Sustainable Energy Reviews, vol. 13, pp. 2111-2118, 2009.

[91] A. Angelis-Dimakis, M. Biberacher, J. Dominguez, G. Fiorese, S. Gadocha, E. Gnansounou, G. Guariso, A. Kartalidis, L. Panichelli, I. Pinedo, and M. Robba, "Methods and tools to evaluate the availability of renewable energy sources," Renewable and Sustainable Energy Reviews, vol. 15, pp. 1182-1200, 2011.

[92] JICA, "Population density by basic grid square," ed, 2007.

[93] BPS, "Metadata For National Agriculture statistics," 2004.

[94] W. Cox, "World Urban Areas: 8th Annual Edition: Version 2 " Demographia2012.

[95] P. Denholm and R. M. Margolis, "Evaluating the limits of solar photovoltaics (PV) in traditional electric power systems," Energy Policy, vol. 35, pp. 2852-2861, 2007.

[96] M. Campbell, J. Blunden, E. Smeloff, and P. Aschenbrenner, "Minimizing utility-scale PV power plant LCOE through the use of high capacity factor configurations," in Photovoltaic Specialists Conference (PVSC), 200934 th IEEE, 2009, pp. 000421-000426.

[97] Bank Indonesia, "BI Rate," 2012.

[98] D. C. Jordan and S. R. Kurtz, "Photovoltaic degradation rates—an analytical review," Progress in Photovoltaics: Research and Applications, vol. 21, pp. 12-29, 2013.

[99] Solarbuzz. (2012). Module Pricing. Available: http://www.solarbuzz.com/facts-andfigures/retail-price-environment/module-prices

[100] NREL, "The Prospect for \$1/Watt Electricity from Solar," ed, 2010.

[101] IPCC, Special Report on Renewable Energy Sources and Climate Change Mitigation. United Kingdom and New York, NY, USA: Cambridge University Press, 2011.

[102] Divisi Mekanisme Perdagangan Karbon. (2009). Emission factors for Kalimantan and Sulawesi grids (2009). Available: http://pasarkarbon.dnpi.go.id

[103] Divisi Mekanisme Perdagangan Karbon. (2011). Updates on Emission Factors of Electricity Interconnection Systems (2011). Available: http://pasarkarbon.dnpi.go.id

[104] Tax and Custom Incentives for Activity used Renewable Energy, M. o. Finance 21/2010, 2010.

[105] The Jakarta Post, "Govt to set prices for wind, solar plants," in The Jakarta Post, ed, 2012.

[106] International Renewable Energy Agency, "RENEWABLE ENERGY TECHNOLOGIES: COST ANALYSIS SERIES. Solar Photovoltaics.," 2012.

[107] IEG, "The Welfare Impact of Rural Electrification: A Reassessment of the Costs and Benefits. An IEG impact evaluation.," World Bank2008.

[108] Clean Development Mechanism. (2012, Annex 5 - Rationale for default factors used in the proposed methodology SSC-I.L "Electrification of rural communities using renewable energy". Available: https://cdm.unfccc.int/Panels/ssc_wg/meetings/035/ssc_035_an05.pdf 
[109] J. Gibson and S. Olivia, "The Effect of Infrastructure Access and Quality on Non-Farm Enterprises in Rural Indonesia," World Development, vol. 38, pp. 717-726, 2010.

[110] Center for International Earth Science Information Network - CIESIN - Columbia University, "National Aggregates of Geospatial Data Collection: Population, Landscape, And Climate Estimates, Version 3 (PLACE III)," ed. Palisades, NY: NASA Socioeconomic Data and Applications Center (SEDAC), 2012.

[111] SWECO, "Assessing technology options for rural electrification. Guidelines for project development," 2009.

[112] M. S. Boedoyo and A. Sugiyono. (2010) Decentralized power generation in Indonesia Current issues and prospects. Tech Monitor. 6.

[113] P. Díaz, R. Peña, J. Muñoz, C. Arias, and D. Sandoval, "Field analysis of solar PV-based collective systems for rural electrification," Energy, vol. 36, pp. 2509-2516, 2011.

[114] A. Jossen, J. Garche, and D. U. Sauer, "Operation conditions of batteries in PV applications," Solar Energy, vol. 76, pp. 759-769, 2004.

[115] P. Diaz, M. A. Egido, and F. Nieuwenhout, "Dependability analysis of stand-alone photovoltaic systems," Progress in Photovoltaics: Research and Applications, vol. 15, pp. 245-264, 2007.

[116] V. Svoboda, H. Wenzl, R. Kaiser, A. Jossen, I. Baring-Gould, J. Manwell, P. Lundsager, H. Bindner, T. Cronin, P. Nørgård, A. Ruddell, A. Perujo, K. Douglas, C. Rodrigues, A. Joyce, S. Tselepis, N. van der Borg, F. Nieuwenhout, N. Wilmot, F. Mattera, and D. U. Sauer, "Operating conditions of batteries in off-grid renewable energy systems," Solar Energy, vol. 81, pp. 1409-1425, 2007.

[117] A. J. Veldhuis, A. H. M. E. Reinders, and F. J. A. M. v. Houten, "Comparison of BIPV Simulation with Monitored Data: The Case of a $35 \mathrm{kWp}$ PV System in Jayapura, Papua, Indonesia," in 27th European Photovoltaic Solar Energy Conference and Exhibition, Frankfurt, 2012, pp. 3971 - 3974.

[118] A. Nobre, Z. Ye, H. Cheetamun, T. Reindl, J. Luther, and C. Reise, "High Performing PV Systems for Tropical Regions-Optimization of Systems Performance," in 27th European Photovoltaic Solar Energy Conference and Exhibition, Messe Frankfurt, Germany, 2012, pp. 37633769.

[119] G. J. Ward, "The RADIANCE lighting simulation and rendering system," in Proceedings of the 21st annual conference on Computer graphics and interactive techniques, 1994, pp. 459-472.

[120] PVsyst. (2014). PVsyst. Available: http://www.pvsyst.com/en/

[121] HOMER Energy LLC. (2014). HOMER Energy. Available: http://www.homerenergy.com/

[122] SketchUp. (2014). SketchUp. Available: http://www.sketchup.com

[123] A. J. Veldhuis and A. H. M. E. Reinders, "Real-Time Irradiance Simulation for PV Products and Building Integrated PV in a Virtual Reality Environment," Photovoltaics, IEEE Journal of, vol. 2, pp. 352-358, 2012.

[124] J. Orgill and K. Hollands, "Correlation equation for hourly diffuse radiation on a horizontal surface," Solar Energy, vol. 19, pp. 357-359, 1977.

[125] E. Skoplaki, A. G. Boudouvis, and J. A. Palyvos, "A simple correlation for the operating temperature of photovoltaic modules of arbitrary mounting," Solar Energy Materials and Solar Cells, vol. 92, pp. 1393-1402, 2008.

[126] CSUN, "CSUN250 -60M," ed, 2014.

[127] M. D. Archer and R. Hill, Clean electricity from photovoltaics. London: Imperial College Press, 2001.

[128] M. Koehl, M. Heck, S. Wiesmeier, and J. Wirth, "Modeling of the nominal operating cell temperature based on outdoor weathering," Solar Energy Materials and Solar Cells, vol. 95, pp. 1638-1646, 2011. 
[129] A. D. Jones and C. P. Underwood, "A thermal model for photovoltaic systems," Solar Energy, vol. 70, pp. 349-359, 2001.

[130] M. Almaktar, H. Abdul Rahman, M. Y. Hassan, and I. Saeh, "Artificial neural network-based photovoltaic module temperature estimation for tropical climate of Malaysia and its impact on photovoltaic system energy yield," Progress in Photovoltaics: Research and Applications, pp. n/a$\mathrm{n} / \mathrm{a}, 2013$.

[131] S. Armstrong and W. Hurley, "A thermal model for photovoltaic panels under varying atmospheric conditions," Applied Thermal Engineering, vol. 30, pp. 1488-1495, 2010.

[132] J.-Y. Ye, K. Ding, T. Reindl, and A. G. Aberle, "Outdoor PV Module Performance under Fluctuating Irradiance Conditions in Tropical Climates," Energy Procedia, vol. 33, pp. 238247, 2013.

[133] L. H. I. Lim and Z. Ye, "A dynamic thermal modelling of solar panels using frequency-domain method," Solar Energy, vol. 105, pp. 428-437, 2014.

[134] E. Amy de la Breteque, "Thermal aspects of c-Si photovoltaic module energy rating," Solar Energy, vol. 83, pp. 1425-1433, 2009.

[135] R. G. Ross, "Interface design considerations for terrestrial solar cell modules," in Proceedings of the 12th IEEE Photovoltaic Specialists Conference, Baton Rouge, LA, USA, 1976, pp. 801-806.

[136] Z. Ye, A. Nobre, T. Reindl, J. Luther, and C. Reise, "On PV module temperatures in tropical regions," Solar Energy, vol. 88, pp. 80-87, 2013.

[137] A. J. Veldhuis, A. Nobre, T. Reindl, R. Ruther, and A. H. M. E. Reinders, "The influence of wind on the temperature of PV modules in tropical environments, evaluated on an hourly basis," in Photovoltaic Specialists Conference (PVSC), 2013 IEEE 39th, 2013, pp. 0824-0829.

[138] J. Zhang, A. Gupta, and J. Baker, "Effect of Relative Humidity on the Prediction of Natural Convection Heat Transfer Coefficients," Heat Transfer Engineering, vol. 28, pp. 335-342, 2007.

[139] W. F. Marion, B. Kroposki, K. Emery, J. Del Cueto, D. Myers, and C. Osterwald, Validation of photovoltaic module energy ratings procedure at NREL: National Renewable Energy Laboratory, 1999.

[140] R. Luna-Rubio, M. Trejo-Perea, D. Vargas-Vázquez, and G. Ríos-Moreno, "Optimal sizing of renewable hybrids energy systems: A review of methodologies," Solar Energy, vol. 86, pp. 10771088, 2012.

[141] M. Rumbayan, A. Abudureyimu, and K. Nagasaka, "Mapping of solar energy potential in Indonesia using artificial neural network and geographical information system," Renewable and Sustainable Energy Reviews, vol. 16, pp. 1437-1449, 2012.

[142] M. H. Sulistiyo, L. Banchongphanith, and S. Kaneko, "Identifying Household Residential Electricity Un-subscribers under Two Electricity Subsidy Regimes in Indonesia," Journal of international development and cooperation, vol. 18, pp. 31-43, 2011.

[143] S. S. S. R. Depuru, L. Wang, and V. Devabhaktuni, "Electricity theft: Overview, issues, prevention and a smart meter based approach to control theft," Energy Policy, vol. 39, pp. 1007-1015, 2011.

[144] M. S. Bhalla, "Transmission and Distribution Losses (Power)," in National Conference on Regulation in infrastructure Services: progress and way forward., New Delhi, 2000.

[145] T. B. Smith, "Electricity theft: a comparative analysis," Energy Policy, vol. 32, pp. 2067-2076, 2004.

[146] A. Kovach and J. Schmid, "Determination of energy output losses due to shading of buildingintegrated photovoltaic arrays using a raytracing technique," Solar Energy, vol. 57, pp. 117-124, 1996. 
[147] N. Reich, W. Van Sark, W. Turkenburg, and W. Sinke, "Using CAD software to simulate PV energy yield-The case of product integrated photovoltaic operated under indoor solar irradiation," Solar Energy, vol. 84, pp. 1526-1537, 2010.

[148] N. Reich, W. Van Sark, A. Reinders, and H. de Wit, "Using CAD software to simulate PV energy yield: Predicting the charge yield of solar cells incorporated into a PV powered consumer product under 3D-irradiation conditions," in Photovoltaic Specialists Conference (PVSC), 2009 34th IEEE, 2009, pp. 001291-001296.

[149] S. R. Buss, 3D computer graphics: a mathematical introduction with OpenGL: Cambridge University Press, 2003.

[150] H. Matsukawa, P. Pimentel, T. Izawa, S. Ike, H. Koizumi, and K. Kurokawa, "An integrated design software for photovoltaic systems," in Photovoltaic Energy Conversion, 2003. Proceedings of 3rd World Conference on, 2003, pp. 1930-1933.

[151] T. Tomori, K. Otani, K. Sakuta, and K. Kurokawa, "On-site BIPV array shading evaluation tool using stereo-fisheye photographs," in Photovoltaic Specialists Conference, 2000. Conference Record of the Twenty-Eighth IEEE, 2000, pp. 1599-1602.

[152] A. Woyte, J. Nijs, and R. Belmans, "Partial shadowing of photovoltaic arrays with different system configurations: literature review and field test results," Solar Energy, vol. 74, pp. 217 233, 2003.

[153] M. Horvat and M.-C. Dubois, "Tools and methods for solar design-an overview of IEA SHC Task 41, Subtask B," Energy Procedia, vol. 30, pp. 1120-1130, 2012.

[154] G. Hasle, K.-A. Lie, and E. Quak, Geometric Modelling, Numerical Simulation, and Optimization: Springer, 2007.

[155] Act-3D B.V. (July 2011). Quest3D. Available: http://quest3d.com

[156] R. Perez, R. Stewart, C. Arbogast, R. Seals, and J. Scott, "An anisotropic hourly diffuse radiation model for sloping surfaces: description, performance validation, site dependency evaluation," Solar Energy, vol. 36, pp. 481-497, 1986.

[157] J. Spencer, "Fourier series representation of the position of the sun," Search, vol. 2, pp. 172$172,1971$.

[158] M. Santamouris, I. Tselepidaki, and N. Dris, "Evaluation of models to predict solar radiation on tilted surfaces for the Mediterranean region," Solar \& Wind Technology, vol. 7, pp. 585-589, 1990.

[159] D. Reindl, W. Beckman, and J. Duffie, "Evaluation of hourly tilted surface radiation models," Solar Energy, vol. 45, pp. 9-17, 1990.

[160] T. Muneer and G. Saluja, "A brief review of models for computing solar radiation on inclined surfaces," Energy Conversion and Management, vol. 25, pp. 443-458, 1985.

[161] M. Blanco-Muriel, D. C. Alarcón-Padilla, T. López-Moratalla, and M. Lara-Coira, "Computing the solar vector," Solar Energy, vol. 70, pp. 431-441, 2001.

[162] L. Williams, "Casting curved shadows on curved surfaces," in ACM Siggraph Computer Graphics, 1978, pp. 270-274.

[163] F. C. Crow, "Shadow algorithms for computer graphics," in ACM SIGGRAPH Computer Graphics, 1977, pp. 242-248.

[164] M. Haller, S. Drab, and W. Hartmann, "A real-time shadow approach for an augmented reality application using shadow volumes," in Proceedings of the ACM symposium on Virtual reality software and technology, 2003, pp. 56-65.

[165] E. Lengyel, Mathematics for 3D game programming and computer graphics: Cengage Learning, 2012.

[166] NREL. (July). Available: http://www.nrel.gov/midc/lmu/

[167] W. Zaaiman and A. Colli, "Single axis tracking and fix-tilt performance of C-SI systems in the Italian Alpine region," in Proc. 37th IEEE Photovolt. Spec. Conf, 2011. 


\section{Publications}

1. Veldhuis, A.J.; Nobre, A.M.; Peters, I.M.; Reindl, T.; Ruther, R.; Reinders, A.H.M.E., An Empirical Model for Rack-Mounted PV Module Temperatures for Southeast Asian Locations Evaluated for Minute Time Scales, Photovoltaics, IEEE Journal of, vol.5, no.3, pp.774-782, May 2015.

2. Veldhuis, A.J.; Reinders, A.H.M.E., Virtual Reality Simulation of Power Produced by a Building Added PV System in Indonesia, 29th European Photovoltaic Solar Energy Conference and Exhibition, Amsterdam, 22-26 September 2014 .

3. Reinders, A.H.M.E.; Veldhuis, H.; Susandi, A.; Indartono, Y.S.; Halim, B.; Iswarayoga, N., PV Electricity in Indonesia - A Sustainable Transition with Great Potential, 29th European Photovoltaic Solar Energy Conference and Exhibition, Amsterdam, 22-26 September 2014.

4. Veldhuis, A.J.; Reinders, A.H.M.E., Performance of a 34 kWp Grid-Connected PV System in Indonesia; A Comparison of Tropical and European PV Systems, 40th IEEE Photovoltaic Specialists Conference, Denver, 8-13 June 2014.

5. Veldhuis, A.J.; Reinders, A.H.M.E., Potential and Cost-Effectiveness of OffGrid PV Systems in Indonesia Evaluated on a Provincial Level, 40th IEEE Photovoltaic Specialists Conference, Denver, 8-13 June 2014.

6. Veldhuis, A.J.; Reinders, A.H.M.E., Reviewing the potential and costeffectiveness of grid-connected solar PV in Indonesia on a provincial level, Renewable and Sustainable Energy Reviews, Vol 27, pp 315-324, November 2013.

7. Veldhuis, A.J.; Nobre, A.; Reindl, T.; Rüther, R.; Reinders, A.H.M.E., The Influence of Wind on the Temperature of PV Modules in Tropical Environments, Evaluated on an Hourly Basis, 39th Photovoltaic Specialists Conference, Tampa, 16-21 June 2013. 
8. Veldhuis, A. J.; Reinders, A.H.M.E., Real-Time Irradiance Simulation for PV Products and Building Integrated PV in a Virtual Reality Environment, Photovoltaics, IEEE Journal of, vol.2, no.3, pp. 352-358, July 2012.

9. Veldhuis, H.; Reinders, A.H.M.E.; Houten, F.J.A.M. van, Comparison of BIPV simulation with monitored data: the case of a $35 \mathrm{kWp}$ PV system in Jayapura, Papua, Indonesia, 27th EU Photovoltaic Solar Energy Conference and Exhibition, Frankfurt, 24-28 September 2012, pp. 3971-3974.

10. Reinders, A.H.M.E.; Veldhuis, H.; Susandi, A., Grid-Connected PV Systems for Island Electrification in Indonesia, 26th EU Photovoltaic Solar Energy Conference and Exhibition, Hamburg, 5-9 September 2011, pp. 4323-4327.

11. Veldhuis, H.; Reinders, A., Real-time irradiance simulation for PV products and building integrated PV in a virtual dynamic environment, Proceedings of 37th IEEE Photovoltaic Specialists Conference, Seattle, 19-24 June 2011, pp. 193.

12. Reinders, A.; Veldhuis, H.; Susandi, A., Development of Grid-Connected PV Systems for Remote Electrification in Indonesia, Proceedings of 37th IEEE Photovoltaic Specialists Conference, Seattle, 19-24 June 2011, pp. 2420-2425. 
Appendices 


\section{A. Illegal electricity consumption in Indonesia}

The data from BPS as shown in Fig. 2.2 reveal that 18\% of all Indonesian households have an illegal connection to PLN's electricity grid. Detailed information about the illegal electricity consumption is lacking, because PLN does not mention anything about illegal customers in their annual reports and literature about this topic is limited. However, a study by Sulistiyo et al. [142] estimated the number of illegal connections by comparing the statistics from the National Socio-economic Survey (SUSENAS) data and PLN's annual reports for 2004 and 2008 . They found that $28 \%$ and $21 \%$ of the total connections of PLN were illegal, in 2004 and 2008 respectively. This is in the same order of the data based on the census from BPS [24], in which 20\% of the total PLN connections (i.e. legal and illegal) is illegal. Therefore is assumed that the number of illegal connections based on data from BPS is correct.

This raises questions about how this illegal electricity consumption is intertwined in PLN's data. It is important to know how this is included in the statistics, since this can influence the electricity demand per household.

If the illegal connection is made between the distribution substation and the household, the corresponding consumption is probably included in the energy losses shown in the PLN data. The overall distribution losses of PLN in 2010 are 12,254 GWh, which is $7.5 \%$ of their net electricity production. Compared with the estimated illegal electricity consumption by Sulistiyo et al. [142] of respectively 4,207 GWh and 3,442 GWh for 2004 and 2008, the illegal electricity consumption is roughly $30 \%$ of the overall distribution losses.

At the other hand, if the illegal connection is made after a billing meter from a legally connected household, the illegal electricity consumption is included in the electricity bill of the particular customer. Since this is harder to proof, a closer look at the energy losses per province will be made to see whether the first option is reasonable or not.

To be able to compare the data from BPS with the data from PLN, data from the same year are used. Since PLN provides the data of the production, losses and consumption of electricity per region (PLN operational unit), this short analysis is carried out for either (a) the smallest region defined by PLN or (b) a region consisting of interconnected operational units and/or provinces. 


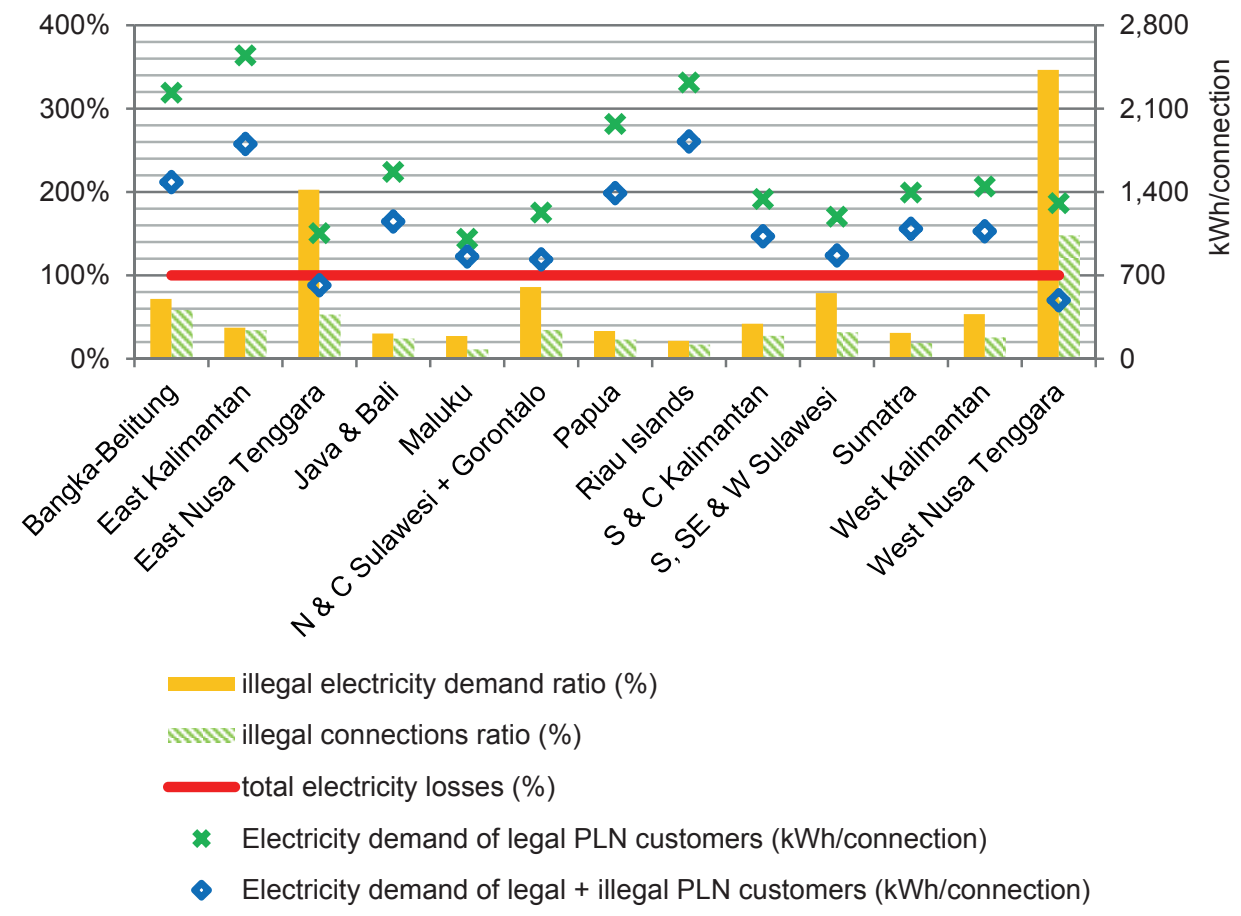

Fig. A.1. The illegal electricity demand compared with the total electricity losses. The illegal demand ratio is the calculated electricity demand of illegal connections as percentage of the total electricity losses per region. The illegal connections ratio is the ratio between legal and illegal residential connections in the specific region. The total electricity losses are set at $100 \%$ as a guide for the eye. 'PLN connections' shows the average electricity consumption per residential customers of PLN. The 'PLN + illegal connections' shows the electricity demand per connection if illegal connections are included in the total residential electricity demand. Data from PLN [25] and BPS [24], both from the year 2010 .

The illegal electricity demand ratio in Fig. A.1 is based on an assumption of 100 $\mathrm{kWh} /$ capita/year, multiplied by the average household size times the number of illegal connections per region. With on average 4 persons per household in Indonesia, the average household demand is about $400 \mathrm{kWh} /$ year. The illegal connections ratio in Fig. A.1 is the ratio between the legal and illegal connections in the specific region. The regions of West Nusa Tenggara (WNT) and East Nusa Tenggara (ENT) show an illegal electricity demand which is significant higher than the electricity losses in both regions. Even if the electricity demand would be decreased by $50 \%$, the illegal demand would still exceed the limit posed by the total electricity losses in both regions. Another remarkable point is the illegal connections ratio of WNT, which is much higher compared with other regions. Except for the regions WNT and ENT, the assumed electricity demand of illegal customers is lower than the total distribution losses. On average, the illegal electricity demand - excluding 
WNT and ENT - is 47\% of the total distribution losses per region and varies between $22 \%$ and $86 \%$, which is still high.

The total distribution losses consist of technical (e.g. power dissipation) and commercial losses (e.g. theft) [143-145]. The technical power losses for distribution vary usually between $6-15 \%$ [144], with the most efficient countries having transmission and distribution (T\&D) losses of less than $6 \%[144,145]$. Due to theft, some countries have T\&D losses exceeding 40\% [144, 145].

In Fig. A.2 the variation in total distribution losses is shown as percentage of the net electricity production per region. The losses fit in the normal range of 6-15\%; however it could be that parts of these losses include electricity theft. Since the quality of electricity distribution across Indonesia is assumed to vary as well, there is assumed that $2 \%$ of the distribution losses are commercial losses. Based on these commercial losses and the total number of households with an illegal connection, the electricity consumption per connection is determined and shown in Fig. A.2 as well.

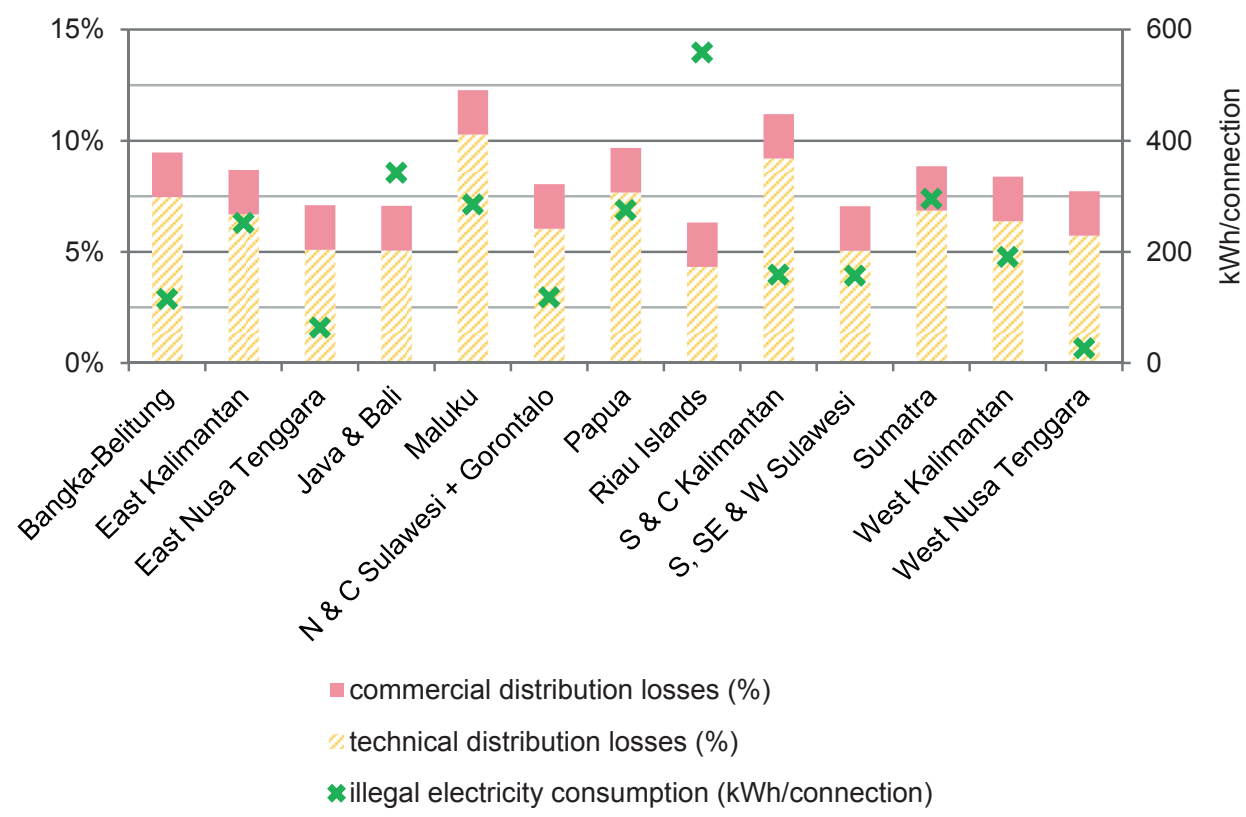

Fig. A.2. Electricity losses and average illegal electricity consumption per region. The technical and commercial distribution losses as ratio of the net electricity production. The average electricity consumption of illegal consumers is the ratio of commercial distribution losses and the total number of illegal consumers. Based on assumptions and PLN data from 2010 [25].

Based on these assumptions, the average annual electricity consumption of households with an illegal connection is $220 \mathrm{kWh}$, which is low but possible. Logically, the lowest average annual electricity consumption is found in WNT and equals $27 \mathrm{kWh} /$ connection. This would correspond to one 40 Watt light bulb which is turned on for less than 2 hours 
every day of the year. It is questionable whether this extremely low electricity consumption is realistic.

In the scenario that the illegal consumption is included in the electricity sold by PLN, it is common-sense that the average electricity demand per connection decreases. In Fig. A.1 these differences in electricity consumption per connection are shown. The lowest average electricity consumption is found for the region of WNT with $491 \mathrm{kWh} /$ customer, if the households with illegal connection to PLN's electricity grid are included in the total electricity sold to residential customers. This is still a reasonable amount of electricity for a household, however in this scenario illegal consumers would steal their electricity from their neighbors which is not very common [143]. Nevertheless, it could be that the illegal consumers do not steal as such, but pay their neighbor for their illegal electricity use. This situation can be explained by the fact that PLN is not capable in keeping their electricity production in pace with the electricity demand. As long as their generation capacity is insufficient, PLN does not allow new connections to be made in order to keep the electricity supply stable. Moreover, making an illegal connection can be dangerous, can easily be detected during maintenance and is a criminal offense.

Therefore, the illegal consumption is assumed to be mainly included in the electricity sold by PLN. Furthermore, on basis of Fig. A.1 and Fig. A.2 there can be concluded that large spatial differences exist, both for electricity consumption and distribution losses. 


\section{B. Details PV system Jayapura}

\section{B.1 CEEG SST 240-60M PV module}

TABLE B-1: CHARACTERISTICS OF THE CEEG SST 240-60M PV MODULE

\begin{tabular}{|c|c|}
\hline \multicolumn{2}{|c|}{ Electrical characteristics } \\
\hline STC Power Rating $\mathrm{P}_{\mathrm{mp}}(\mathrm{W})$ & 240 \\
\hline Open Circuit Voltage $V_{\text {oc }}(\mathrm{V})$ & 37.0 \\
\hline Short Circuit Current $\mathrm{I}_{\mathrm{sc}}(\mathrm{A})$ & 8.62 \\
\hline Voltage at Maximum Power $\mathrm{V}_{\mathrm{mp}}(\mathrm{V})$ & 29.8 \\
\hline Current at Maximum Power $I_{\mathrm{mp}}(\mathrm{A})$ & 8.06 \\
\hline Panel Efficiency & $14.78 \%$ \\
\hline Maximum System Voltage $V_{\max }(\mathrm{V})$ & 1000 \\
\hline Maximum Series Fuse Rating (A) & 15 \\
\hline \multicolumn{2}{|c|}{ Temperature coefficients } \\
\hline Temperature Coefficiency of $\mathrm{I}_{s c}$ & $0.039 \% /{ }^{\circ} \mathrm{C}$ \\
\hline Temperature Coefficiency of $V_{o c}$ & $-0.307 \% /{ }^{\circ} \mathrm{C}$ \\
\hline Temperature Coefficiency of $\mathrm{P}_{\mathrm{mp}}$ & $-0.423 \% /{ }^{\circ} \mathrm{C}$ \\
\hline \multicolumn{2}{|c|}{ Mechanical characteristics } \\
\hline Cell Type & Monocrystalline Cell \\
\hline Cell Size $(\mathrm{mm})$ & $156 \times 156$ \\
\hline Cells & $6 \times 10$ \\
\hline Dimensions & $1640.0 \times 990.0 \times 50.0 \mathrm{~mm}(39.0 \times 64.6 \times 2.0 \mathrm{inch})$ \\
\hline Weight & $19.8 \mathrm{~kg}(43.7 \mathrm{lbs})$ \\
\hline Junction Box (Safety Rating, Bypass Diodes) & 6 bypass diodes \\
\hline Cable (Length, Cable Cross-Section) & $900 \mathrm{~mm}, 4 \mathrm{~mm}$ \\
\hline Front Cover (Thickness,Material) & White toughened safety glass, $3.2 \mathrm{~mm}$ \\
\hline Backsheet Cover (Color, Thickness, Material) & composite film \\
\hline Encapsulation Materials & EVA (Ethylene-vinyl acetate) \\
\hline Frame Material & Anodized aluminium alloy \\
\hline
\end{tabular}

Source: http://www.gsenergy.eu/doc/csun-ceeg/datasheets/240-260M-Datasheet.pdf 


\section{B.2 AmpleSun ASF100 PV module}

TABLE B-2: CHARACTERISTICS OF THE AMPLESUn ASF100 PV MODULE

\begin{tabular}{ll}
\hline & Electrical characteristics \\
\hline Maximum Power[W] & 100 \\
\hline Maximum power voltage $[\mathrm{V}]$ & 77 \\
\hline Maximum power current $[\mathrm{A}]$ & 1.29 \\
\hline Open circuit voltage $[\mathrm{V}]$ & 99 \\
\hline Short circuit current $[\mathrm{A}]$ & 1.65 \\
\hline & Temperature coefficients \\
\hline Maximum power $(\mathrm{W})$ & $-0.2 \% /{ }^{\circ} \mathrm{C}$ \\
\hline Maximum power voltage $(\mathrm{V})$ & $-0.32 \% /{ }^{\circ} \mathrm{C}$ \\
\hline Maximum power current $(\mathrm{A})$ & $0.14 \% /{ }^{\circ} \mathrm{C}$ \\
\hline Open circuit voltage $(\mathrm{V})$ & $-0.33 \% /{ }^{\circ} \mathrm{C}$ \\
\hline Short circuit current $(\mathrm{A})$ & $0.09 \% /{ }^{\circ} \mathrm{C}$ \\
\hline & Mechanical characteristics \\
\hline Dimension[mm] & $\mathrm{L} 1,414 \times \mathrm{W} 1,114 \times \mathrm{T} 37.5 / 35$ \\
\hline Weight $[$ Kg] & $21 / 20$ \\
\hline Connector & $\mathrm{MC}$ or $\mathrm{MC}$ equivalent \\
\hline Cable length [mm] & 1,000 \\
\hline Cable size $[\mathrm{mm}]$ & 2.5 \\
\hline Source $\mathrm{http} / /$ www & \\
\hline
\end{tabular}




\section{Monthly performance of the PV system in Jayapura}

\section{C.1 Definitions}

\section{C.1.1 Monitoring fraction}

The monitoring fraction, $M F$, is the ratio of errorless data points and the total possible data points and shows which part of the considered monitoring time is monitored correctly. The monitoring fraction is based on the measurements from the data logger.

where

$$
M F=\left(1-\frac{\text { total errors }}{\text { total possible records }}\right) \times 100 \%
$$

- Total errors are the records with errors and missing records

- Total possible records i.e. total minutes in the specific month

\section{C.1.2 PV system availability}

Since the WebBox records the data in a 10 -minute interval ${ }^{25}$, the 1 -minute monitoring data of the data logger is averaged over 10 minutes and subsequently both files are combined. Only the period of the day with daylight is taken into account, since the WebBox records only when the inverters are active. Usually, the WebBox data ranges from 05:40 am till 5:50 pm. If a WebBox record is missing in this time period, it is counted as a missing record. There is assumed that when a record from the WebBox is missing, that the system is not available (i.e. disconnected from the grid and therefore not delivering AC power).

The availability fraction, $B F$, is calculated as follows:

$$
B F=\left(1-\frac{\text { total missing records WebBox }}{\text { total records WebBox }+ \text { total missing records WebBox }}\right) \times 100 \%
$$

where

- Total missing records Webbox are the records of the WebBox files which are missing

- $\quad$ Total records WebBox are the all the records from the WebBox.

\footnotetext{
${ }^{25}$ From the $14^{\text {th }}$ of November 2013 and onwards the recording interval of the WebBox has been changed to 5 minutes.
} 


\section{C.1.3 Energy yields}

$\mathrm{H}_{\mathrm{i}, \mathrm{u}} \quad$ : $\quad$ The total irradiation ${ }^{26}$

$\mathrm{E}_{\mathrm{A}} \quad$ : $\quad$ DC energy supplied by PV array, calculated from array power

$\mathrm{E}_{\mathrm{FI}} \quad$ : $\quad$ AC energy supplied by inverter

$\mathrm{E}_{\mathrm{LT}} \quad$ : $\quad$ DC energy losses due to temperature

$\eta_{\mathrm{dc}} \quad$ : $\quad$ DC efficiency $\left(E_{A} / H_{i, u} * A\right) * 100 \%$

$\eta_{\text {inv }} \quad: \quad$ Inverter efficiency $\left(E_{F I} / E_{A}\right)^{*} 100 \%$

$\eta_{\text {sys }} \quad: \quad$ System efficiency $\left(E_{F I} / H_{i, u}{ }^{*} A\right)^{*} 100 \%$

$$
\eta_{d c, 25}=\frac{\sum_{i=1}^{N} P_{A}(i) \cdot\left[1-\beta_{m p p} \cdot\left[T_{m}(i)-25\right]\right] \cdot \Delta t}{H_{i, u}} \times 100 \%
$$

with:

$\eta_{\mathrm{dc}, 25} \quad: \quad$ Temperature corrected DC efficiency

$\mathrm{P}_{\mathrm{A}}(\mathrm{i}) \quad$ : $\quad$ Array power measured at interval $i$

$\mathrm{T}_{\mathrm{m}}(\mathrm{i}) \quad: \quad$ Module temperature measured at interval $i$

$\Delta \mathrm{t} \quad: \quad$ Time interval $(1 \mathrm{~min})$

$\beta_{\mathrm{mpp}} \quad: \quad$ Temperature coefficient of the power of the modules

$\mathrm{N} \quad$ : $\quad$ Number of records in period

\section{C.1.4 Performance ratio}

The performance ratio is defined as:

$$
P R=\frac{E_{F I} \cdot G_{S T C}}{H_{i, u} \cdot P_{S T C}} \times 100 \%
$$

where

- $\mathrm{E}_{\mathrm{FI}} \quad=$ the $\mathrm{AC}$-energy supplied by the inverter $(\mathrm{kWh})$

- $\mathrm{H}_{\mathrm{i}, \mathrm{u}} \quad=$ the available irradiation $\left(\mathrm{kWh} / \mathrm{m}^{2}\right)$

- $\mathrm{P}_{\text {STC }}=$ the installed power of the PV array under STC (W)

- $\mathrm{G}_{\mathrm{STC}}=$ the irradiance under STC $\left(=1,000 \mathrm{~W} / \mathrm{m}^{2}\right)$

\footnotetext{
${ }^{26}$ Since the reference cell had not been attached until November 2013, the global horizontal irradiation has been used instead for the earlier performance calculations.
} 


\section{C.2 May 2013}

In Table C-1 metadata about the monitoring data are shown.

TABLE C-1: METADATA MAY 2013

\begin{tabular}{llrr}
\hline Device & Period & Records & Recording interval \\
\hline Data logger & $01-05-2013-31-05-2013$ & 44,640 & 1 minute \\
\hline WebBox & $01-05-2013-30-05-2013$ & 2,110 & 10 minutes \\
\hline
\end{tabular}

In Fig. C. 1 the inverter efficiencies are shown for the STP1, STP2 and SMC PV array. In Fig. C.2 the temperature-corrected DC-efficiencies of the SMA inverters are shown. Records with an irradiance exceeding $1,200 \mathrm{kWh}$ are excluded from this figure, since these values are disputable. In total 24 records are left out.

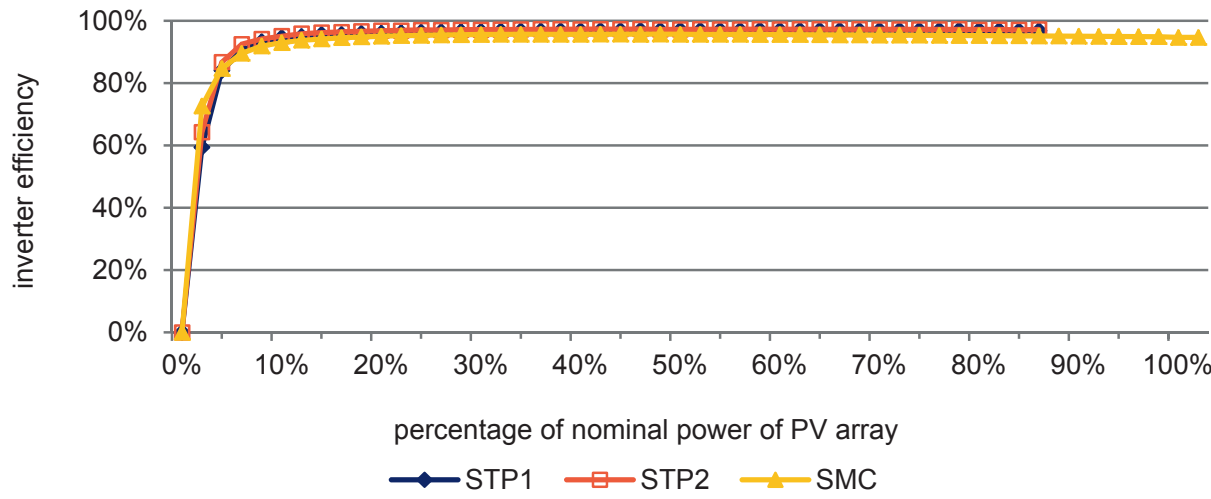

Fig. C.1. Inverter efficiency (\%) of the STP1, STP2 and SMC PV array as function of the array power for the month May 2013. Calculated for 50 linear divided power classes, based on measurements from the WebBox.

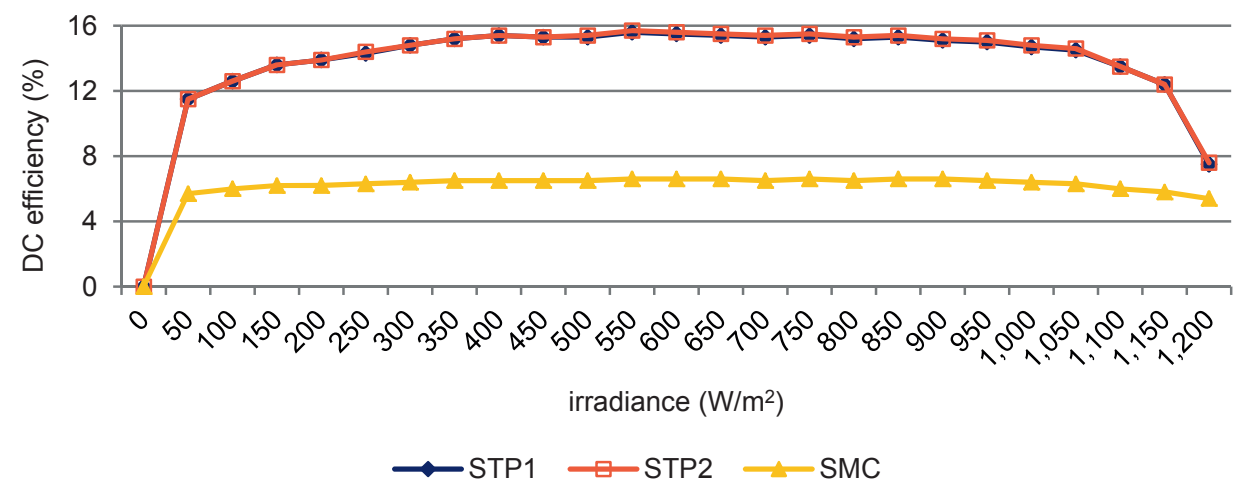

Fig. C.2. Average, temperature-corrected DC-efficiency as function of the irradiance per range of 50 $\mathrm{W} / \mathrm{m}^{2}$ for the month May 2013. 


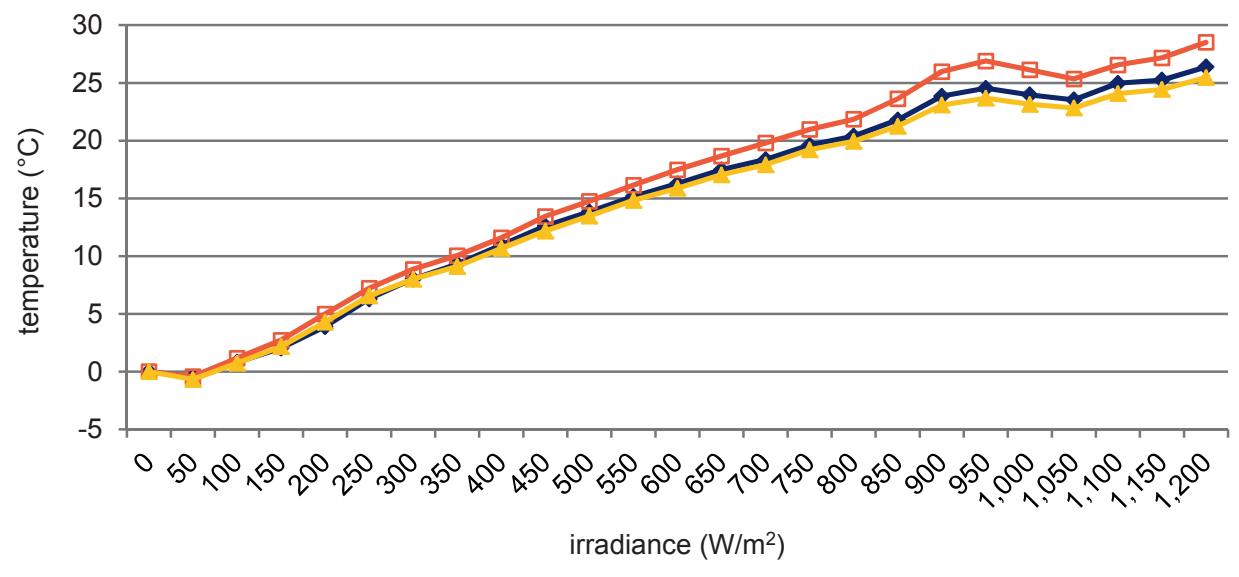

$\longrightarrow$ Tm-x,1 $\longrightarrow$ Tm-x,2

Fig. C.3 Difference in temperature between ambient and PV module temperatures as function of the irradiance per range of $50 \mathrm{~W} / \mathrm{m}^{2}$ for May 2013.

TABLE C-2: ENERGY YIELDS OF DIFFERENT SUBSYSTEMS FOR MAY 2013

\begin{tabular}{|c|c|c|c|c|c|c|c|}
\hline PV array & $\begin{array}{r}\text { MF } \\
\%\end{array}$ & $\begin{array}{r}\text { BF } \\
\%\end{array}$ & $\begin{array}{r}\mathrm{H}_{\mathrm{i}, \mathrm{u}} \\
\mathrm{kWh} / \mathrm{m}^{2}\end{array}$ & $\begin{array}{l}\mathrm{E}_{\mathrm{A}, \mathrm{DL}} \\
\mathrm{kWh}\end{array}$ & $\begin{array}{l}E_{A, W B} \\
k W h\end{array}$ & $\begin{array}{r}E_{F I} \\
k W h\end{array}$ & $\begin{array}{r}\mathrm{E}_{\mathrm{LT}} \\
\mathrm{kWh}\end{array}$ \\
\hline STP1 & \multirow{3}{*}{96} & 95 & 144 & \multirow{2}{*}{1,532} & 1,449 & 1,401 & 148 \\
\hline STP2 & & 95 & 144 & & 1,453 & 1,410 & 157 \\
\hline SMC & & 95 & 144 & 1,081 & 1,013 & 964 & 49 \\
\hline Involar & 96 & 95 & 144 & 219 & - & - & 22 \\
\hline
\end{tabular}

TABLE C-3: KEY FIGURES OF DIFFERENT SUbSYSTEMS FOR MAY 2013

\begin{tabular}{lrrrrrr}
\hline PV array & $\begin{array}{rrrrr}\boldsymbol{\eta}_{\mathrm{dc}} \\
\%\end{array}$ & $\begin{array}{r}\boldsymbol{\eta}_{\mathrm{dc}, 25} \\
\%\end{array}$ & $\begin{array}{r}\boldsymbol{\eta}_{\text {inv }} \\
\%\end{array}$ & $\begin{array}{r}\boldsymbol{\eta}_{\text {sys }} \\
\%\end{array}$ & $\begin{array}{r}\text { PR } \\
\%\end{array}$ & $\begin{array}{r}\text { PR } \\
\%\end{array}$ \\
\hline STP1 & 13.6 & 14.9 & 96.7 & 13.4 & 81.3 & - \\
\hline STP2 & 13.6 & 15.0 & 97.1 & 13.5 & 81.9 & - \\
\hline SMC & 6.2 & 6.5 & 95.2 & 5.9 & 93.3 & $77.7^{*}$ \\
\hline Involar & - & - & - & 8.2 & 50.0 & $58.4^{+}$ \\
\hline
\end{tabular}

*If PR of SMC is based on $120 \mathrm{~W}_{\mathrm{p}}$ (initial) instead of $100 \mathrm{~W}_{\mathrm{p}}$ (stabilized) PV modules.

+If all errors are due to grid instability. 


\section{C.3 June 2013}

In Table C-4 metadata about the monitoring data are shown.

TABLE C-4: MeTADATA JunE 2013

\begin{tabular}{llrr}
\hline Device & Period & Records & Recording interval \\
\hline Data logger & $01-06-2013-30-06-2013$ & 42,885 & 1 minute \\
\hline WebBox & $19-06-2013-30-06-2013$ & 877 & 10 minutes \\
\hline
\end{tabular}

In Fig. C.4 the inverter efficiencies are shown for the STP1, STP2 and SMC PV array. In Fig. C.5 the temperature-corrected DC-efficiencies of the SMA inverters are shown.

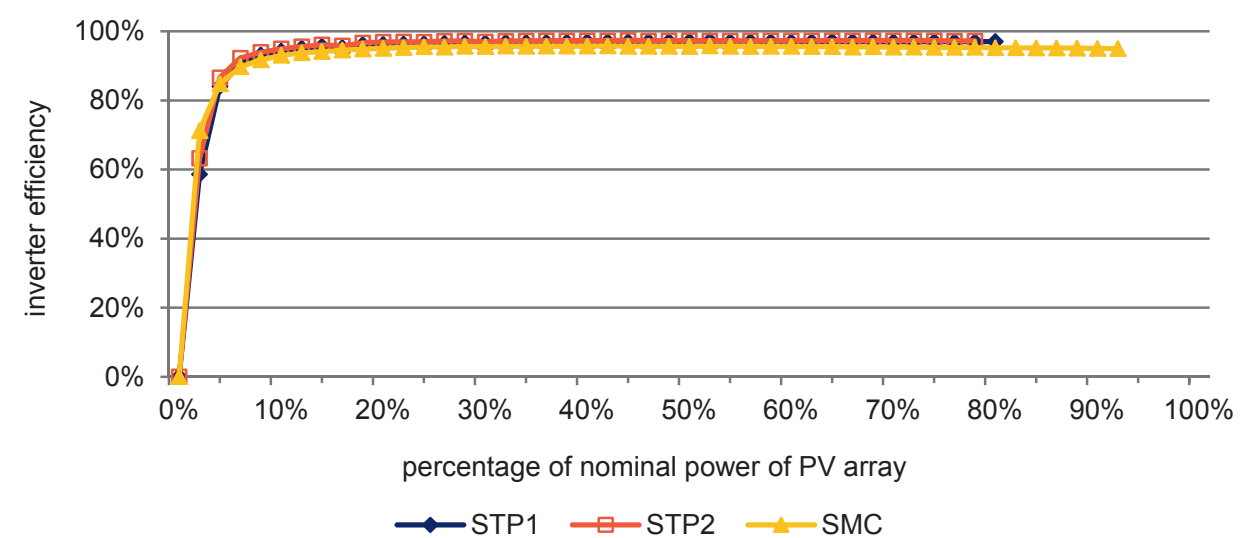

Fig. C.4. Inverter efficiency (\%) of the STP1, STP2 and SMC PV array as function of the array power for the month June 2013. Calculated for 50 linear divided power classes, based on measurements from the WebBox.

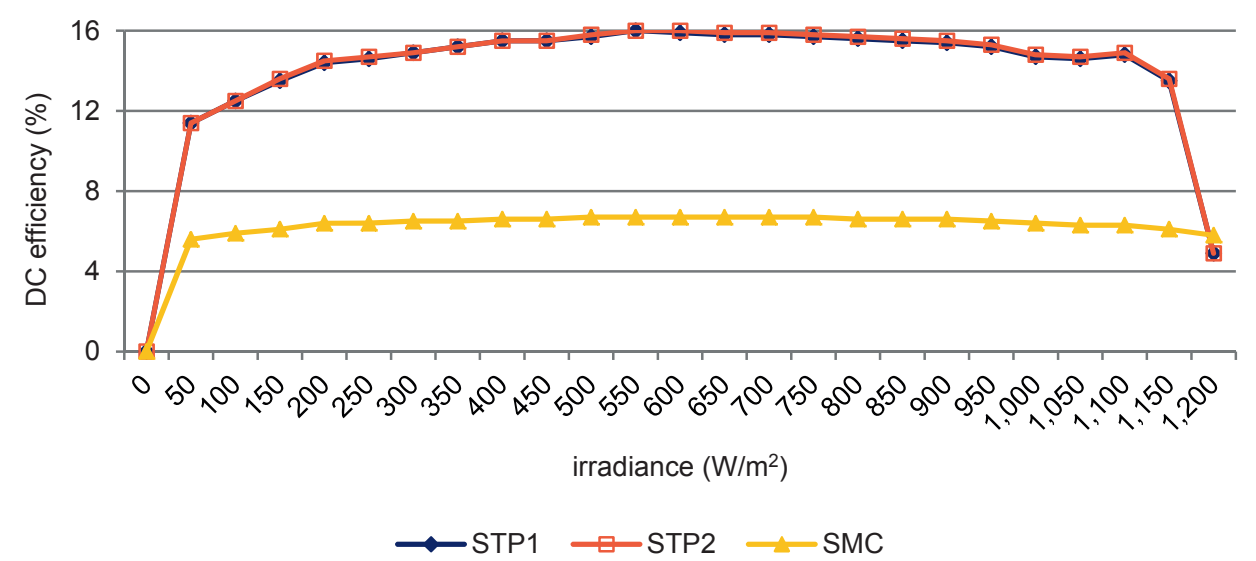

Fig. C.5. Average, temperature-corrected DC-efficiency as function of the irradiance per range of 50 $\mathrm{W} / \mathrm{m}^{2}$ for the month June 2013 . 


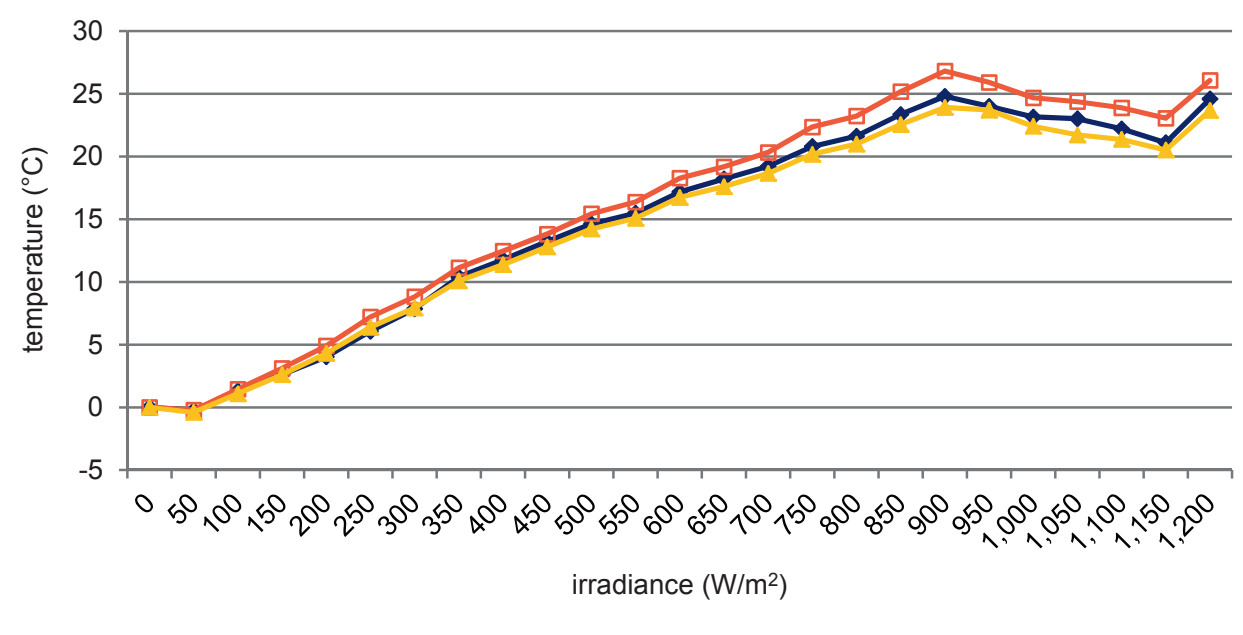

$\longrightarrow$ Tm-x,1 $\longrightarrow$ Tm-x,2 $\longrightarrow$ Tm-a

Fig. C.6. Difference in temperature between ambient and PV module temperatures as function of the irradiance per range of $50 \mathrm{~W} / \mathrm{m}^{2}$ for June 2013 .

TABLE C-5: ENERGY YIELDS OF DIFFERENT SUBSYSTEMS FOR JUNE 2013

\begin{tabular}{|c|c|c|c|c|c|c|c|}
\hline PV array & $\begin{array}{r}\text { MF } \\
\%\end{array}$ & $\begin{array}{r}\mathrm{BF} \\
\%\end{array}$ & $\begin{array}{r}\mathrm{H}_{\mathrm{i}, \mathrm{u}} \\
\mathrm{kWh} / \mathrm{m}^{2}\end{array}$ & $\begin{array}{l}E_{A, D L} \\
k W h\end{array}$ & $\begin{array}{l}E_{A, W B} \\
k W h\end{array}$ & $\begin{array}{r}\mathrm{E}_{\mathrm{FI}} \\
\mathrm{kWh}\end{array}$ & $\begin{array}{r}\mathrm{E}_{\mathrm{LT}} \\
\mathrm{kWh}\end{array}$ \\
\hline STP1 & \multirow{3}{*}{98} & 99 & 54 & \multirow{2}{*}{1,342} & 557 & 538 & 125 \\
\hline STP2 & & 99 & 54 & & 560 & 543 & 132 \\
\hline SMC & & 99 & 54 & 935 & 385 & 367 & 41 \\
\hline Involar & 98 & 99 & 54 & 190 & - & - & 18 \\
\hline
\end{tabular}

TABLE C-6: KeY FIGURES OF DIFFERENT SUBSYSTEMS FOR JUNE 2013

\begin{tabular}{lrrrrrr}
\hline PV array & $\boldsymbol{\eta}_{\mathrm{dc}}$ & $\boldsymbol{\eta}_{\mathrm{dc}, 25}$ & $\begin{array}{r}\boldsymbol{\eta}_{\text {inv }} \\
\%\end{array}$ & $\begin{array}{r}\boldsymbol{\eta}_{\text {sys }} \\
\%\end{array}$ & $\begin{array}{r}\text { PR } \\
\%\end{array}$ & $\begin{array}{r}\text { PR } \\
\%\end{array}$ \\
\hline STP1 & 14.0 & 15.3 & 96.6 & 13.6 & 82.7 & - \\
\hline STP2 & 14.0 & 15.4 & 97.0 & 13.7 & 83.4 & - \\
\hline SMC & 6.3 & 6.6 & 95.3 & 6.0 & 93.9 & $78.3^{*}$ \\
\hline Involar & - & - & - & 9.2 & 55.8 & $61.9^{+}$ \\
\hline
\end{tabular}

*If PR of SMC is based on $120 \mathrm{~W}_{\mathrm{p}}$ (initial) instead of $100 \mathrm{~W}_{\mathrm{p}}$ (stabilized) PV modules.

+If all errors are due to grid instability. 


\section{C.4 July 2013}

In Table C-7 metadata about the monitoring data are shown.

TABLE C-7: MetadATA July 2013

\begin{tabular}{llrr}
\hline Device & Period & Records & Recording interval \\
\hline Data logger & $01-07-2013-31-07-2013$ & 44,619 & 1 minute \\
\hline WebBox & $01-07-2013-31-07-2013$ & 2,147 & 10 minutes \\
\hline
\end{tabular}

In Fig. C.7 the inverter efficiencies are shown for the STP1, STP2 and SMC PV array. In Fig. C.8 the temperature-corrected DC-efficiencies of the SMA inverters are shown. Records with an irradiance exceeding $1,200 \mathrm{kWh}$ are excluded from this figure, since these values are disputable. In total 4 records are left out.

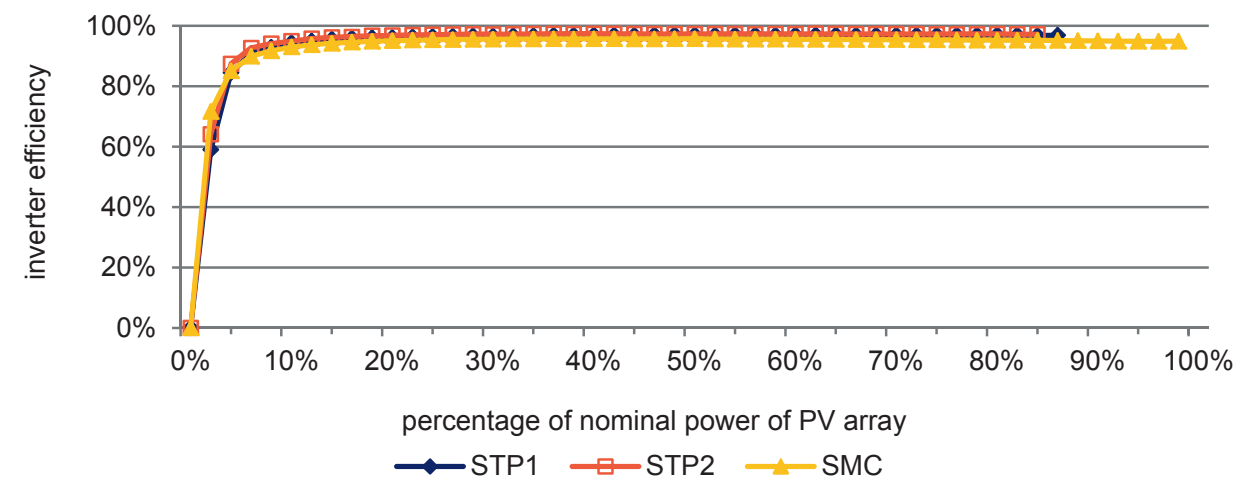

Fig. C.7. Inverter efficiency (\%) of the STP1, STP2 and SMC PV array as function of the array power for the month July 2013. Calculated for 50 linear divided power classes, based on measurements from the WebBox.

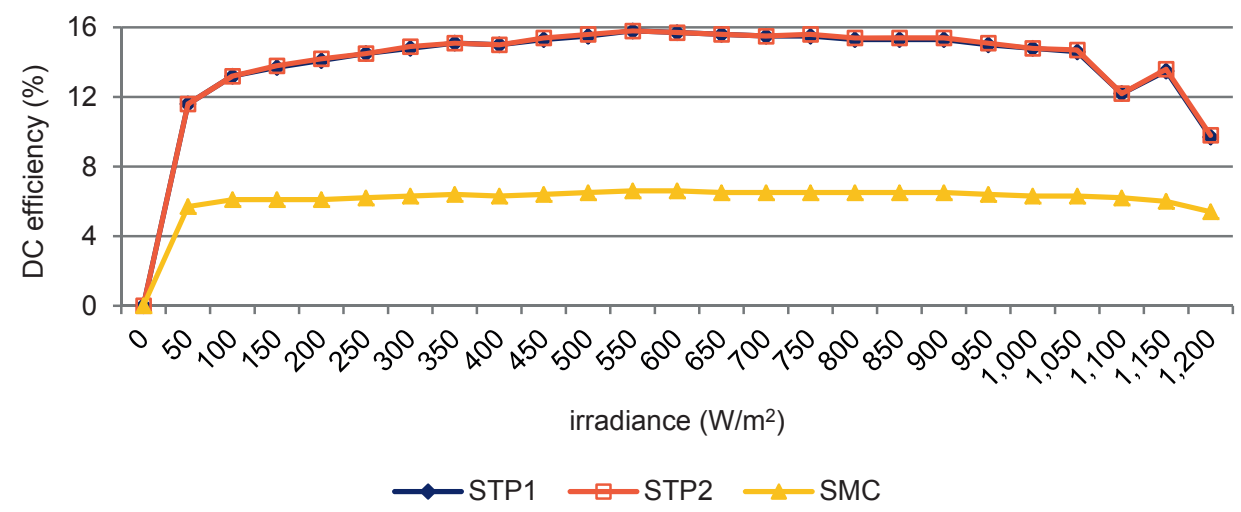

Fig. C.8. Average, temperature-corrected DC-efficiency as function of the irradiance per range of 50 $\mathrm{W} / \mathrm{m}^{2}$ for the month July 2013. 


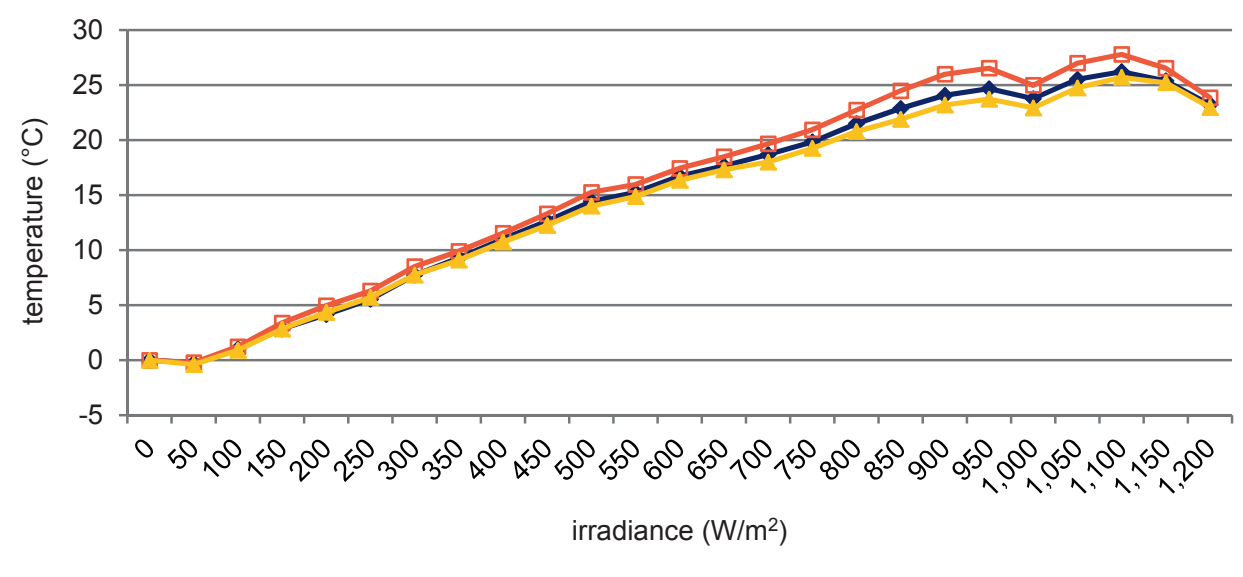

$\longrightarrow \mathrm{Tm}-\mathrm{x}, 1 \longrightarrow \mathrm{Tm}-\mathrm{x}, 2 \longrightarrow \mathrm{Tm}-\mathrm{a}$

Fig. C.9. Difference in temperature between ambient and PV module temperatures as function of the irradiance per range of $50 \mathrm{~W} / \mathrm{m}^{2}$ for July 2013.

TABLE C-8: ENERGY YIELDS OF DIFFERENT SUBSYSTEMS FOR JULY 2013

\begin{tabular}{|c|c|c|c|c|c|c|c|}
\hline PV array & $\begin{array}{r}\text { MF } \\
\% \\
\end{array}$ & $\begin{array}{r}\mathrm{BF} \\
\%\end{array}$ & $\begin{array}{r}\mathrm{H}_{\mathrm{i}, \mathrm{u}} \\
\mathrm{kWh} / \mathrm{m}^{2}\end{array}$ & $\begin{array}{l}\mathrm{E}_{\mathrm{A}, \mathrm{DL}} \\
\mathrm{kWh}\end{array}$ & $\begin{array}{l}E_{A, W B} \\
k W h\end{array}$ & $\begin{array}{r}E_{F I} \\
\mathrm{kWh}\end{array}$ & $\begin{array}{r}\mathrm{E}_{\mathrm{LT}} \\
\mathrm{kWh}\end{array}$ \\
\hline STP1 & \multirow{3}{*}{100} & 95 & 124 & \multirow{2}{*}{1,352} & 1,264 & 1,221 & 119 \\
\hline STP2 & & 95 & 124 & & 1,270 & 1,232 & 125 \\
\hline SMC & & 95 & 124 & 933 & 868 & 826 & 38 \\
\hline Involar & 100 & 95 & 124 & 243 & - & - & 22 \\
\hline
\end{tabular}

TABLE C-9: KEY FIGURES OF DIFFERENT SUBSYSTEMS FOR JULY 2013

\begin{tabular}{lrrrrrr}
\hline \multirow{2}{*}{ PV array } & $\boldsymbol{\eta}_{\mathrm{dc}}$ & $\boldsymbol{\eta}_{\mathrm{dc}, 25}$ & $\begin{array}{r}\boldsymbol{\eta}_{\text {inv }} \\
\%\end{array}$ & $\begin{array}{r}\boldsymbol{\eta}_{\text {sys }} \\
\%\end{array}$ & $\begin{array}{r}\text { PR } \\
\%\end{array}$ & $\begin{array}{r}\text { PR } \\
\text { \% }\end{array}$ \\
\hline STP1 & 13.9 & 15.1 & 96.6 & 13.5 & 82.3 & - \\
\hline STP2 & 13.9 & 15.2 & 97.0 & 13.6 & 83.0 & - \\
\hline SMC & 6.2 & 6.4 & 95.2 & 5.9 & 92.8 & $77.3^{*}$ \\
\hline Involar & - & - & - & 10.6 & 64.3 & $68.1^{+}$ \\
\hline
\end{tabular}

"If PR of SMC is based on $120 \mathrm{~W}_{\mathrm{p}}$ (initial) instead of $100 \mathrm{~W}_{\mathrm{p}}$ (stabilized) PV modules.

+If all errors are due to grid instability. 


\section{C.5 August 2013}

In Table C-10 metadata about the monitoring data are shown.

TABLE C-10: METADATA August 2013

\begin{tabular}{llrr}
\hline Device & Period & Records & Recording interval \\
\hline Data logger & $01-08-2013-31-08-2013$ & 44,640 & 1 minute \\
\hline WebBox & $01-08-2013-29-08-2013$ & 1,978 & 10 minutes \\
\hline
\end{tabular}

In Fig. C.10 the inverter efficiencies are shown for the STP1, STP2 and SMC PV array. In Fig. C.11 the temperature-corrected DC-efficiencies of the SMA inverters are shown. Records with an irradiance exceeding 1,200 kWh are excluded from this figure, since these values are disputable. In total 8 records are left out.

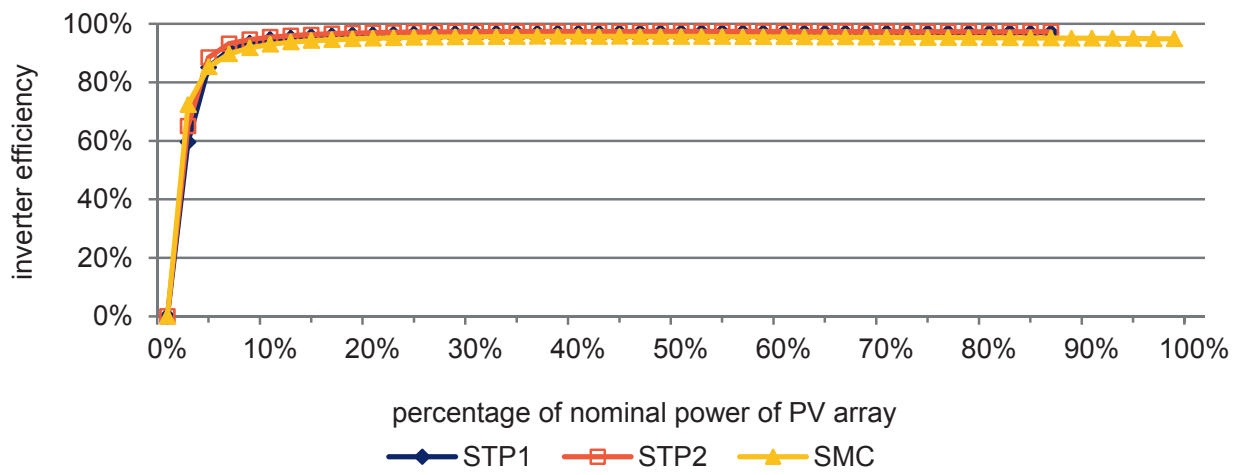

Fig. C.10.Inverter efficiency (\%) of the STP1, STP2 and SMC PV array as function of the array power for the month August 2013. Calculated for 50 linear divided power classes, based on measurements from the WebBox.

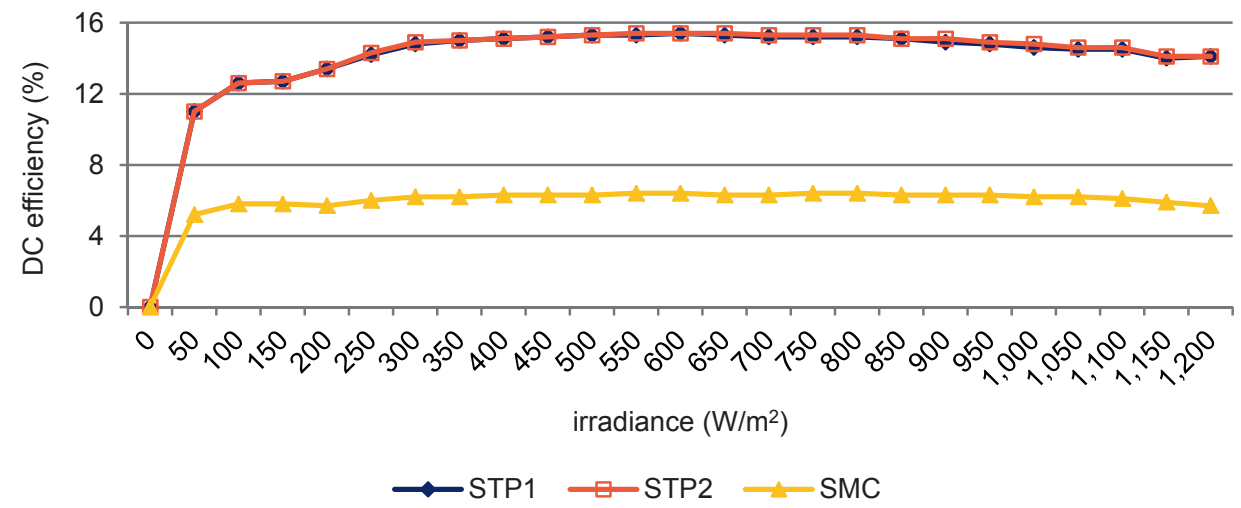

Fig. C.11.Average, temperature-corrected DC-efficiency as function of the irradiance per range of 50 $\mathrm{W} / \mathrm{m}^{2}$ for the month August 2013. 


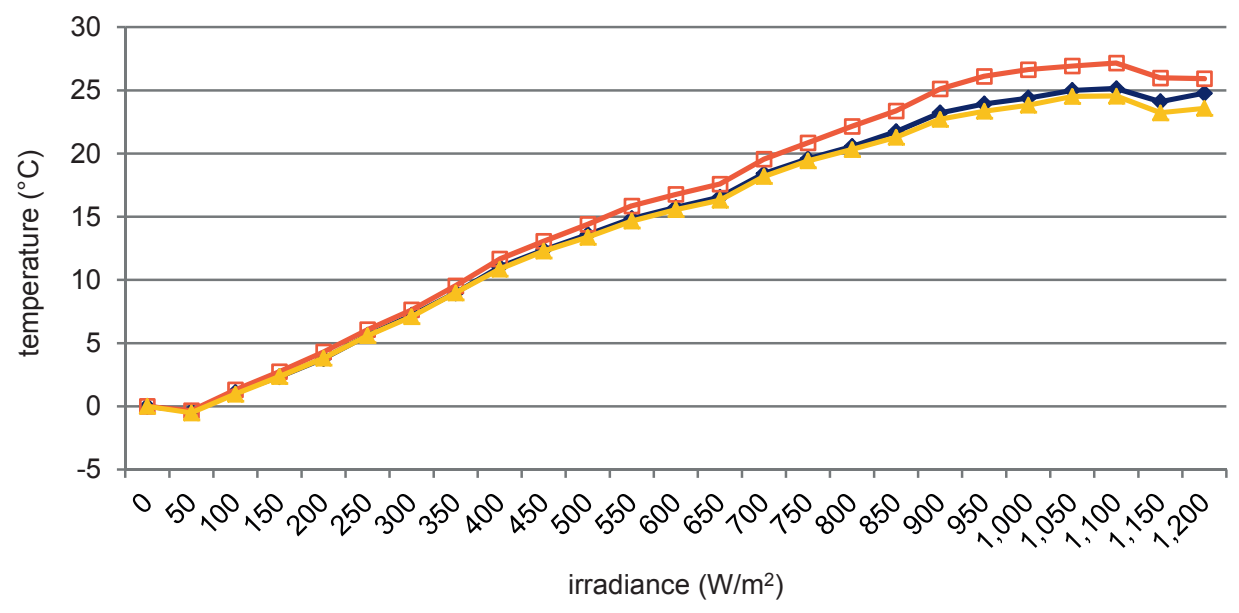

$\longrightarrow$ Tm-x,1 $\longrightarrow$ Tm-x,2 $\longrightarrow$ Tm-a

Fig. C.12.Difference in temperature between ambient and PV module temperatures as function of the irradiance per range of $50 \mathrm{~W} / \mathrm{m}^{2}$ for August 2013.

TABLE C-11: ENERGY YIELDS OF DIFFERENT SUBSYSTEMS FOR AUGUST 2013

\begin{tabular}{|c|c|c|c|c|c|c|c|}
\hline PV array & $\begin{array}{r}\text { MF } \\
\%\end{array}$ & $\begin{array}{r}\mathrm{BF} \\
\%\end{array}$ & $\begin{array}{r}\mathrm{H}_{\mathrm{i}, \mathrm{u}} \\
\mathrm{kWh} / \mathrm{m}^{2}\end{array}$ & $\begin{array}{l}\mathrm{E}_{\mathrm{A}, \mathrm{DL}} \\
\mathrm{kWh}\end{array}$ & $\begin{array}{l}E_{A, W B} \\
k W h\end{array}$ & $\begin{array}{r}E_{F I} \\
k W h\end{array}$ & $\begin{array}{r}\mathrm{E}_{\mathrm{LT}} \\
\mathrm{kWh}\end{array}$ \\
\hline STP1 & \multirow{3}{*}{100} & 92 & 137 & \multirow{2}{*}{1,579} & 1,373 & 1,328 & 147 \\
\hline STP2 & & 92 & 137 & & 1,371 & 1,332 & 156 \\
\hline SMC & & 92 & 137 & 1,082 & 934 & 889 & 48 \\
\hline Involar & 100 & 92 & 137 & 265 & - & - & 26 \\
\hline
\end{tabular}

TABLE C-12: KEY FIGURES OF DIFFERENT SUBSYSTEMS FOR AUGUST 2013

\begin{tabular}{lrrrrrr}
\hline PV array & $\begin{array}{r}\boldsymbol{\eta}_{\mathrm{dc}} \\
\%\end{array}$ & $\begin{array}{r}\boldsymbol{\eta}_{\mathrm{dc}, 25} \\
\%\end{array}$ & $\begin{array}{r}\boldsymbol{\eta}_{\text {inv }} \\
\%\end{array}$ & $\begin{array}{r}\boldsymbol{\eta}_{\text {sys }} \\
\%\end{array}$ & $\begin{array}{r}\text { PR } \\
\%\end{array}$ & $\begin{array}{r}\text { PR } \\
\%\end{array}$ \\
\hline STP1 & 13.6 & 14.9 & 96.8 & 13.3 & 80.6 & - \\
\hline STP2 & 13.6 & 14.9 & 97.2 & 13.3 & 80.8 & - \\
\hline SMC & 6.0 & 6.3 & 95.2 & 5.7 & 89.9 & $75.0^{*}$ \\
\hline Involar & - & - & - & 9.5 & 57.8 & $63.5^{+}$ \\
\hline
\end{tabular}

*If PR of SMC is based on $120 \mathrm{~W}_{\mathrm{p}}$ (initial) instead of $100 \mathrm{~W}_{\mathrm{p}}$ (stabilized) PV modules.

+If all errors are due to grid instability. 


\section{C.6 September 2013}

In Table C-13 metadata about the monitoring data are shown.

TABle C-13: Metadata SePTEMBer 2013

\begin{tabular}{llrr}
\hline Device & Period & Records & Recording interval \\
\hline Data logger & $01-09-2013-30-09-2013$ & 42,244 & 1 minute \\
\hline WebBox & $01-09-2013-30-09-2013$ & 2,013 & 10 minutes \\
\hline
\end{tabular}

In Fig. C.13 the inverter efficiencies are shown for the STP1, STP2 and SMC PV array. In Fig. C.14 the temperature-corrected DC-efficiencies of the SMA inverters are shown. Records with an irradiance exceeding $1,200 \mathrm{kWh}$ are excluded from this figure, since these values are disputable. In total 33 records are left out.

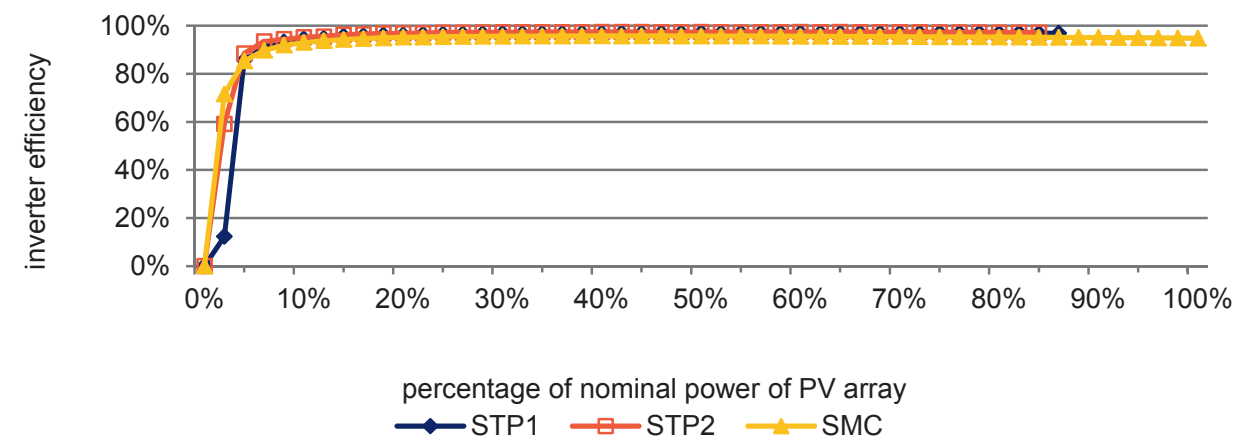

Fig. C.13.Inverter efficiency (\%) of the STP1, STP2 and SMC PV array as function of the array power for the month September 2013. Calculated for 50 linear divided power classes, based on measurements from the WebBox.

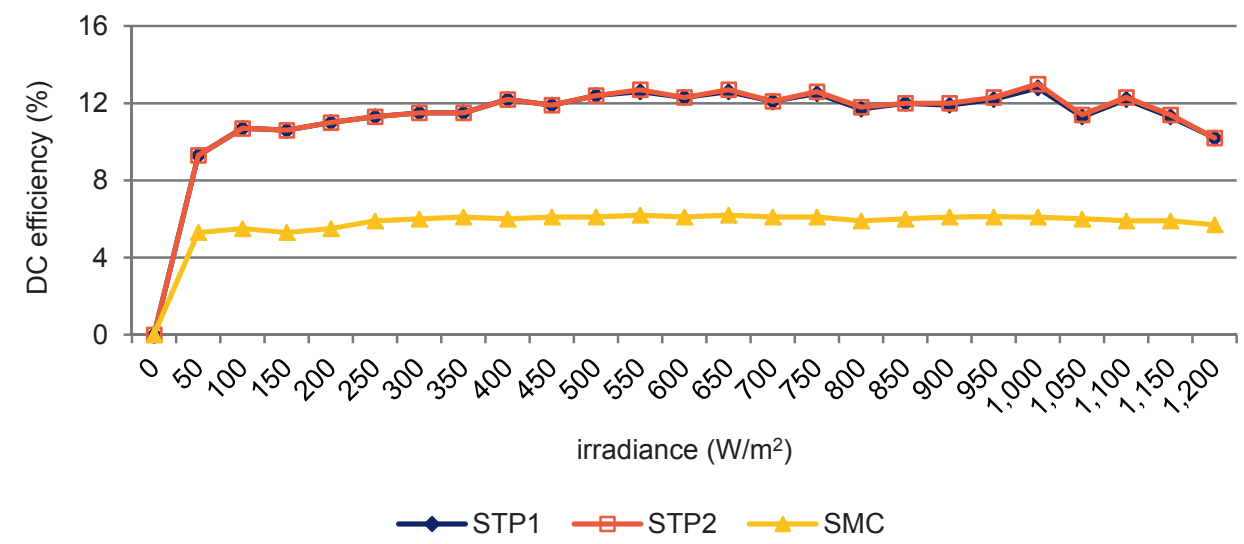

Fig. C.14.Average, temperature-corrected DC-efficiency as function of the irradiance per range of 50 $\mathrm{W} / \mathrm{m}^{2}$ for the month September 2013. 


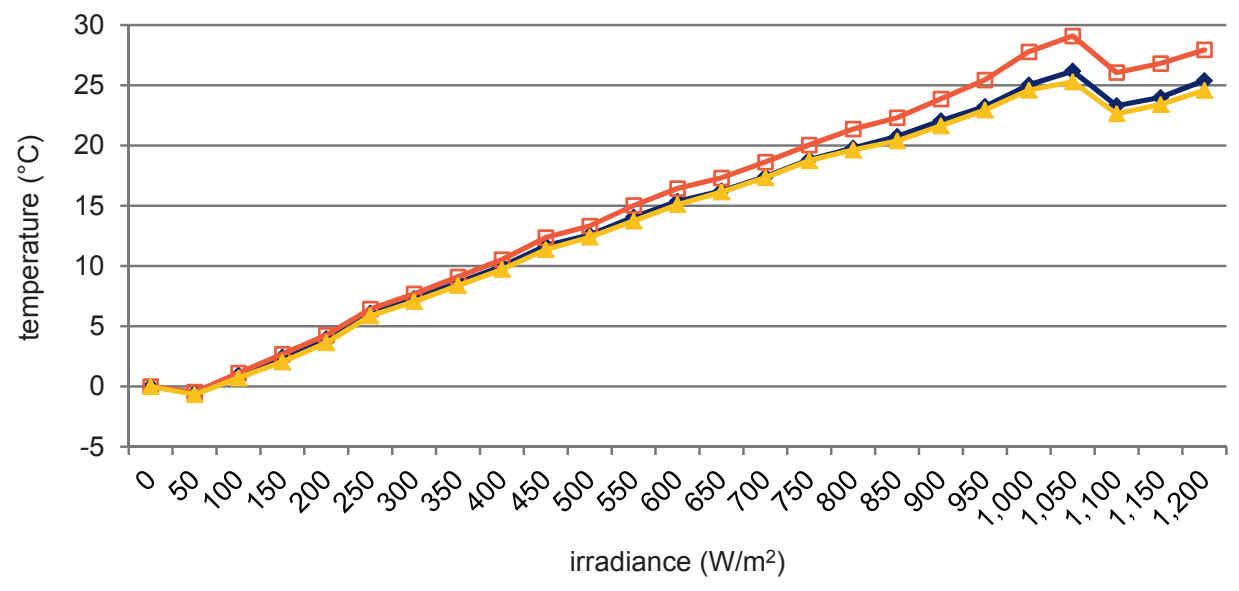

$\longrightarrow$ Tm-x,1 $\because \mathrm{Tm}-\mathrm{x}, 2 \longrightarrow \mathrm{Tm}-\mathrm{a}$

Fig. C.15.Difference in temperature between ambient and PV module temperatures as function of the irradiance per range of $50 \mathrm{~W} / \mathrm{m}^{2}$ for September 2013.

TABLE C-14: ENERGY YIELDS OF DIFFERENT SUBSYSTEMS FOR SEPTEMBER 2013

\begin{tabular}{|c|c|c|c|c|c|c|c|}
\hline PV array & $\begin{array}{r}\mathrm{MF} \\
\%\end{array}$ & $\begin{array}{r}\mathrm{BF} \\
\%\end{array}$ & $\begin{array}{r}\mathrm{H}_{\mathrm{i}, \mathrm{u}} \\
\mathrm{kWh} / \mathrm{m}^{2}\end{array}$ & $\begin{array}{l}\mathrm{E}_{\mathrm{A}, \mathrm{DL}} \\
\mathrm{kWh}\end{array}$ & $\begin{array}{l}E_{A, W B} \\
k W h\end{array}$ & $\begin{array}{r}E_{\text {FI }} \\
\mathrm{kWh}\end{array}$ & $\begin{array}{r}\mathrm{E}_{\mathrm{LT}} \\
\mathrm{kWh}\end{array}$ \\
\hline STP1 & \multirow{3}{*}{98} & 90 & 145 & \multirow{2}{*}{1,235} & 1,208 & 1,166 & 117 \\
\hline STP2 & & 90 & 145 & & 1,382 & 1,342 & 125 \\
\hline SMC & & 90 & 145 & 1,009 & 952 & 907 & 46 \\
\hline Involar & 98 & 90 & 145 & 240 & - & - & 24 \\
\hline
\end{tabular}

TABLE C-15: KeY FIGURES OF DIFFERENT SUBSYSTEMS FOR SEPTEMBER 2013

\begin{tabular}{lrrrrrr}
\hline PV array & $\boldsymbol{\eta}_{\mathrm{dc}}$ & $\boldsymbol{\eta}_{\mathrm{dc}, 25}$ & $\begin{array}{r}\boldsymbol{\eta}_{\text {inv }} \\
\%\end{array}$ & $\begin{array}{r}\boldsymbol{\eta}_{\text {sys }} \\
\%\end{array}$ & $\begin{array}{r}\text { PR } \\
\%\end{array}$ & $\begin{array}{r}\text { PR } \\
\%\end{array}$ \\
\hline STP1 & 10.9 & 12.0 & 96.5 & 11.0 & 67.2 & - \\
\hline STP2 & 10.9 & 12.1 & 97.1 & 12.7 & 77.3 & - \\
\hline SMC & 5.8 & 6.0 & 95.2 & 5.5 & 87.1 & $72.6^{*}$ \\
\hline Involar & - & - & - & 9.0 & 55.0 & $60.1^{+}$ \\
\hline
\end{tabular}

"If PR of SMC is based on $120 \mathrm{~W}_{\mathrm{p}}$ (initial) instead of $100 \mathrm{~W}_{\mathrm{p}}$ (stabilized) PV modules.

+If all errors are due to grid instability. 


\section{C.7 October 2013}

In Table C-16 metadata about the monitoring data are shown.

TABLE C-16: METADATA OCTOBER 2013

\begin{tabular}{llrr}
\hline Device & Period & Records & Recording interval \\
\hline Data logger & $01-10-2013-31-10-2013$ & 43,736 & 1 minute \\
\hline WebBox & $01-10-2013-31-10-2013$ & 2,085 & 10 minutes \\
\hline
\end{tabular}

In Fig. C.16 the inverter efficiencies are shown for the STP1, STP2 and SMC PV array. In Fig. C.17 the temperature-corrected DC-efficiencies of the SMA inverters are shown. Records with an irradiance exceeding $1,200 \mathrm{kWh}$ are excluded from this figure, since these values are disputable. In total 129 records are left out.

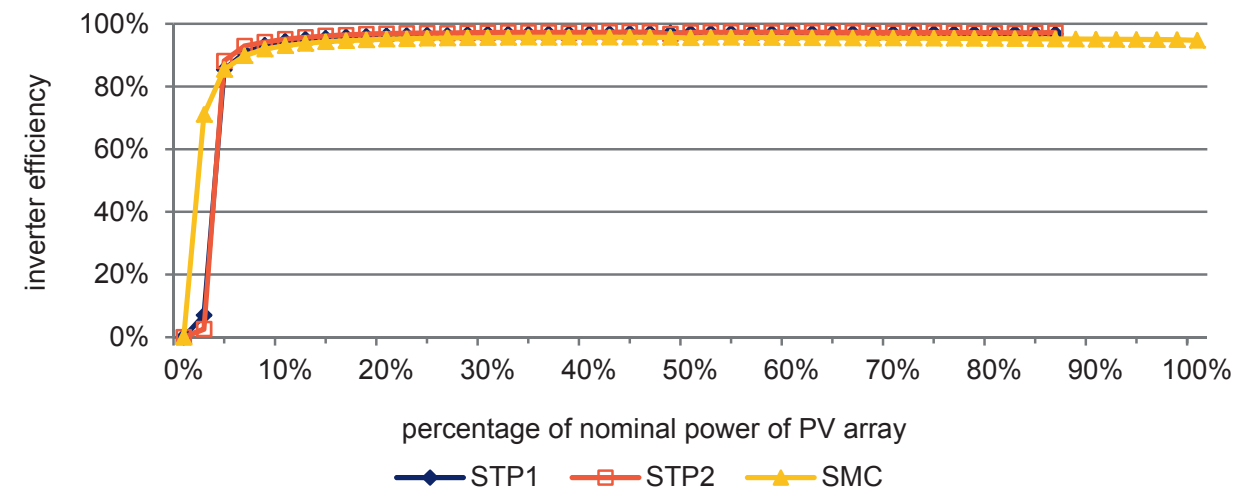

Fig. C.16.Inverter efficiency (\%) of the STP1, STP2 and SMC PV array as function of the array power for the month October 2013. Calculated for 50 linear divided power classes, based on measurements from the WebBox.

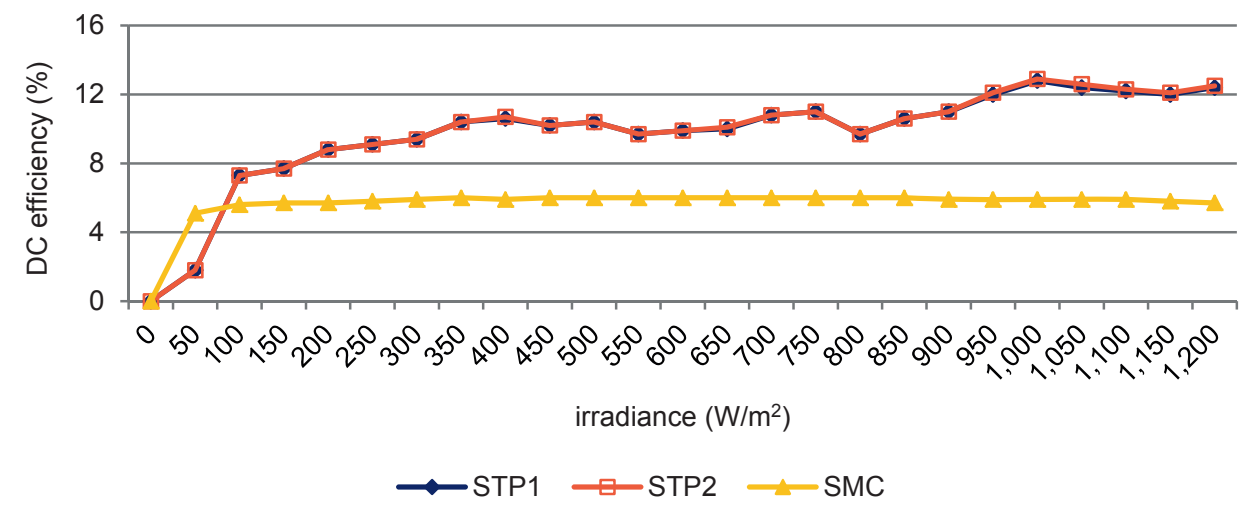

Fig. C.17.Average, temperature-corrected DC-efficiency as function of the irradiance per range of 50 $\mathrm{W} / \mathrm{m}^{2}$ for the month October 2013. 


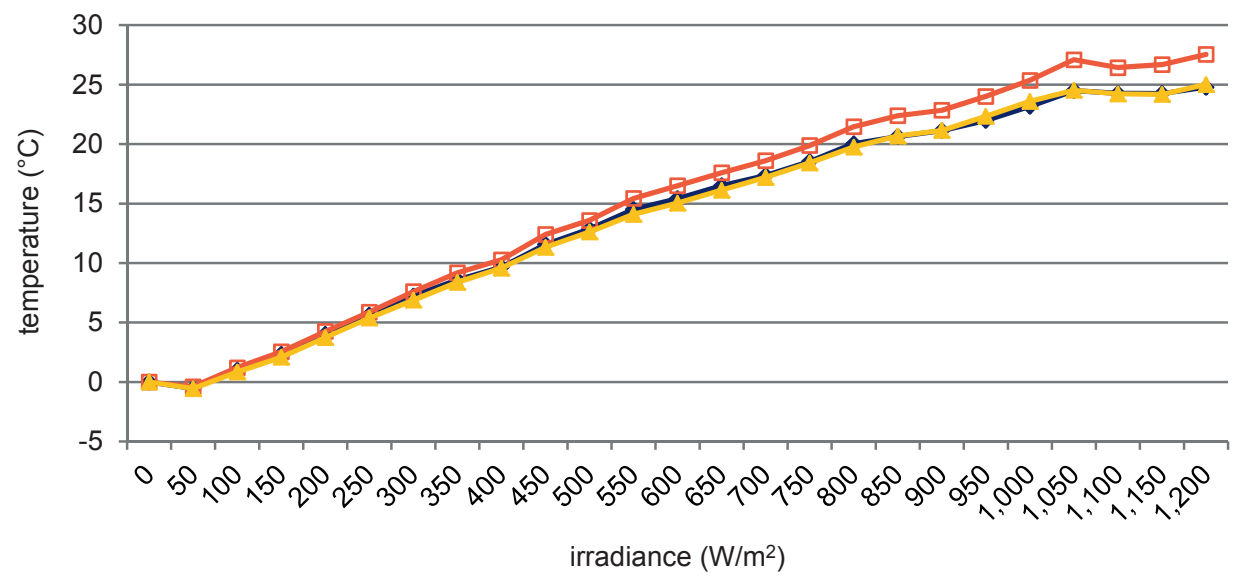

$\longrightarrow$ Tm-x,1 $\longrightarrow$ Tm-x,2 $\longleftarrow$ Tm-a

Fig. C.18. Difference in temperature between ambient and PV module temperatures as function of the irradiance per range of $50 \mathrm{~W} / \mathrm{m}^{2}$ for October 2013.

TABLE C-17: ENERGY YIELDS OF DIFFERENT SUBSYSTEMS FOR OCTOBER 2013

\begin{tabular}{|c|c|c|c|c|c|c|c|}
\hline PV array & $\begin{array}{r}\text { MF } \\
\%\end{array}$ & $\begin{array}{r}\text { BF } \\
\%\end{array}$ & $\begin{array}{r}\mathrm{H}_{\mathrm{i}, \mathrm{u}} \\
\mathrm{kWh} / \mathrm{m}^{2}\end{array}$ & $\begin{array}{l}E_{\mathrm{A}, \mathrm{DL}} \\
\mathrm{kWh}\end{array}$ & $\begin{array}{l}E_{A, W B} \\
k W h\end{array}$ & $\begin{array}{r}\mathrm{E}_{\mathrm{FI}} \\
\mathrm{kWh}\end{array}$ & $\begin{array}{r}\mathrm{E}_{\mathrm{LT}} \\
\mathrm{kWh}\end{array}$ \\
\hline STP1 & \multirow{3}{*}{98} & 90 & 136 & \multirow{2}{*}{1,031} & 1,018 & 979 & 95 \\
\hline STP2 & & 90 & 136 & & 627 & 601 & 101 \\
\hline SMC & & 90 & 136 & 942 & 876 & 834 & 41 \\
\hline Involar & 98 & 90 & 136 & 206 & - & - & 19 \\
\hline
\end{tabular}

TABLE C-18: KEY FIGURES OF DIFFERENT SUBSYSTEMS FOR OCTOBER 2013

\begin{tabular}{lrrrrrr}
\hline PV array & $\boldsymbol{\eta}_{\mathrm{dc}}$ & $\begin{array}{r}\boldsymbol{\eta}_{\mathrm{dc}, 25} \\
\%\end{array}$ & $\begin{array}{r}\boldsymbol{\eta}_{\text {inv }} \\
\%\end{array}$ & $\begin{array}{r}\boldsymbol{\eta}_{\text {sys }} \\
\%\end{array}$ & $\begin{array}{r}\text { PR } \\
\%\end{array}$ & $\begin{array}{r}\text { PR } \\
\%\end{array}$ \\
\hline STP1 & 9.6 & 10.5 & 96.2 & 9.9 & 60.0 & - \\
\hline STP2 & 9.6 & 10.6 & 96.0 & 6.1 & 36.8 & - \\
\hline SMC & 5.7 & 5.9 & 95.2 & 5.4 & 85.2 & $71.0^{*}$ \\
\hline Involar & - & - & - & 8.0 & 48.8 & $60.0^{+}$ \\
\hline
\end{tabular}

"If PR of SMC is based on $120 \mathrm{~W}_{\mathrm{p}}$ (initial) instead of $100 \mathrm{~W}_{\mathrm{p}}$ (stabilized) PV modules.

+If all errors are due to grid instability. 


\section{C.8 November 2013}

In Table C-19 metadata about the monitoring data are shown.

TABle C-19: Metadata November 2013

\begin{tabular}{llrr}
\hline Device & Period & Records & Recording interval \\
\hline Data logger & $01-11-2013-30-11-2013$ & 41,373 & 1 minute \\
\hline WebBox & $01-11-2013-30-11-2013$ & 3,070 & $10 \& 5$ minutes \\
\hline
\end{tabular}

In Fig. C.19 the inverter efficiencies are shown for the STP1, STP2 and SMC PV array. In Fig. C.20 the temperature-corrected DC-efficiencies of the SMA inverters are shown. Records with an irradiance exceeding $1,200 \mathrm{kWh}$ are excluded from this figure, since these values are disputable. In total 102 records are left out.

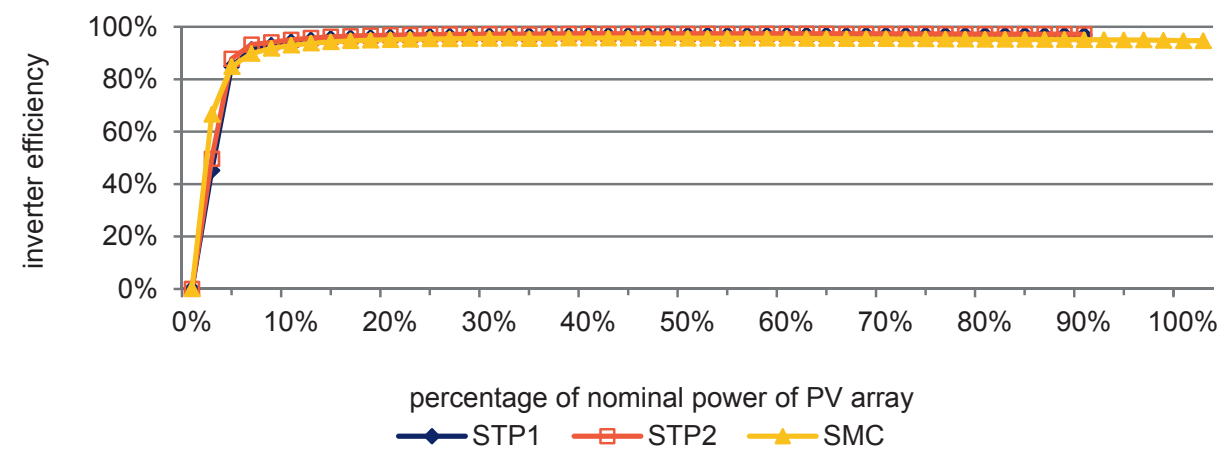

Fig. C.19.Inverter efficiency (\%) of the STP1, STP2 and SMC PV array as function of the array power for the month November 2013. Calculated for 50 linear divided power classes, based on measurements from the WebBox.

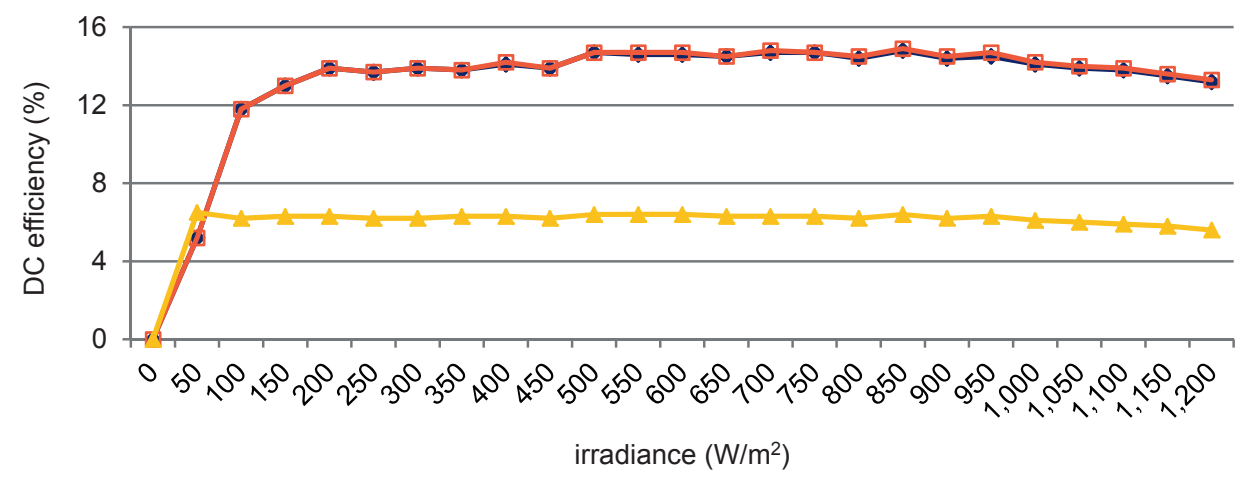

$\multimap$ STP $1 \multimap$ STP2 $\longleftarrow$ SMC

Fig. C.20.Average, temperature-corrected DC-efficiency as function of the irradiance per range of 50 $\mathrm{W} / \mathrm{m}^{2}$ for the month November 2013 . 


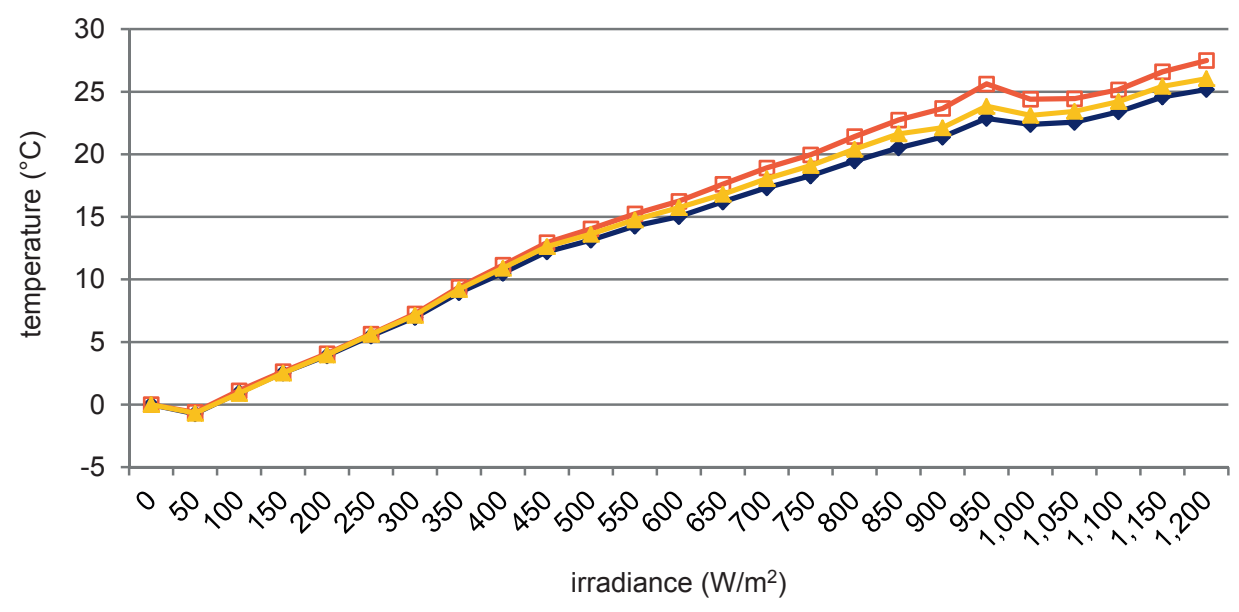

$\multimap \mathrm{Tm}-\mathrm{x}, 1 \multimap \mathrm{Tm}-\mathrm{x}, 2 \longrightarrow \mathrm{Tm}-\mathrm{a}$

Fig. C.21.Difference in temperature between ambient and PV module temperatures as function of the irradiance per range of $50 \mathrm{~W} / \mathrm{m}^{2}$ for November 2013.

TABLE C-20: ENERGY YIELDS OF DIFFERENT SUBSYSTEMS FOR NOVEMBER 2013

\begin{tabular}{|c|c|c|c|c|c|c|c|}
\hline PV array & $\begin{array}{r}\mathrm{MF} \\
\%\end{array}$ & $\begin{array}{r}\mathrm{BF} \\
\%\end{array}$ & $\begin{array}{r}\mathrm{H}_{\mathrm{i}, \mathrm{u}} \\
\mathrm{kW} / \mathrm{h} / \mathrm{m}^{2}\end{array}$ & $\begin{array}{l}\mathrm{E}_{\mathrm{A}, \mathrm{DL}} \\
\mathrm{kWh}\end{array}$ & $\begin{array}{l}E_{A, W B} \\
k W h\end{array}$ & $\begin{array}{r}E_{F I} \\
k W h\end{array}$ & $\begin{array}{r}\mathrm{E}_{\mathrm{LT}} \\
\mathrm{kWh}\end{array}$ \\
\hline STP1 & \multirow{3}{*}{96} & 91 & 123 & \multirow{2}{*}{1,227} & 1,211 & 1,169 & 111 \\
\hline STP2 & & 91 & 123 & & 1,202 & 1,166 & 118 \\
\hline SMC & & 91 & 123 & 880 & 836 & 796 & 39 \\
\hline Involar & 96 & 91 & 123 & 199 & - & - & 19 \\
\hline
\end{tabular}

TABLE C-21: KEY FIGURES OF DIFFERENT SUBSYSTEMS FOR NOVEMBER 2013

\begin{tabular}{lrrrrrr}
\hline \multirow{2}{*}{ PV array } & $\boldsymbol{\eta}_{\mathrm{dc}}$ & $\boldsymbol{\eta}_{\mathrm{dc}, 25}$ & $\begin{array}{r}\boldsymbol{\eta}_{\text {inv }} \\
\%\end{array}$ & $\begin{array}{r}\boldsymbol{\eta}_{\text {sys }} \\
\%\end{array}$ & $\begin{array}{r}\text { PR } \\
\%\end{array}$ & $\begin{array}{r}\text { PR } \\
\%\end{array}$ \\
\hline STP1 & 12.9 & 14.1 & 96.6 & 13.1 & 79.5 & - \\
\hline STP2 & 12.9 & 14.2 & 97.0 & 13.0 & 79.3 & - \\
\hline SMC & 6.0 & 6.2 & 95.2 & 5.7 & 90.1 & $75.1^{*}$ \\
\hline Involar & - & - & - & 8.8 & 53.3 & $61.5^{+}$ \\
\hline
\end{tabular}

"If PR of SMC is based on $120 \mathrm{~W}_{\mathrm{p}}$ (initial) instead of $100 \mathrm{~W}_{\mathrm{p}}$ (stabilized) PV modules.

+If all errors are due to grid instability. 


\section{C.9 December 2013}

In Table C-22 metadata about the monitoring data are shown.

TABLE C-22: METADATA DeCEMBER 2013

\begin{tabular}{llrr}
\hline Device & Period & Records & Recording interval \\
\hline Data logger & $01-12-2013-31-12-2013$ & 35,939 & 1 minute \\
\hline WebBox & $01-12-2013-31-12-2013$ & 4,333 & 5 minutes \\
\hline
\end{tabular}

In Fig. C.22 the inverter efficiencies are shown for the STP1, STP2 and SMC PV array. In Fig. C.23 the temperature-corrected DC-efficiencies of the SMA inverters are shown. Records with an irradiance exceeding $1,200 \mathrm{kWh}$ are excluded from this figure, since these values are disputable. In total 7 records are left out.

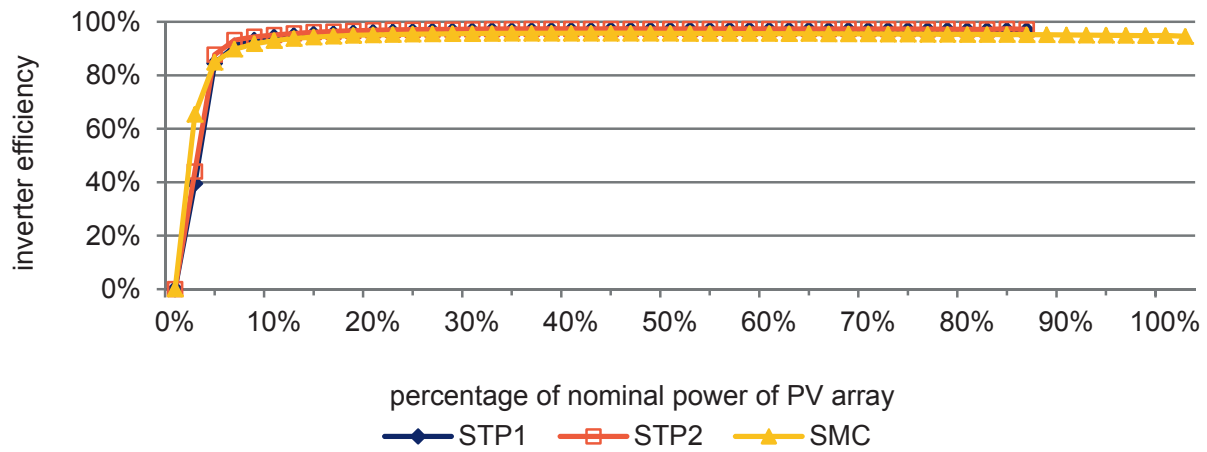

Fig. C.22.Inverter efficiency (\%) of the STP1, STP2 and SMC PV array as function of the array power for the month December 2013. Calculated for 50 linear divided power classes, based on measurements from the WebBox.

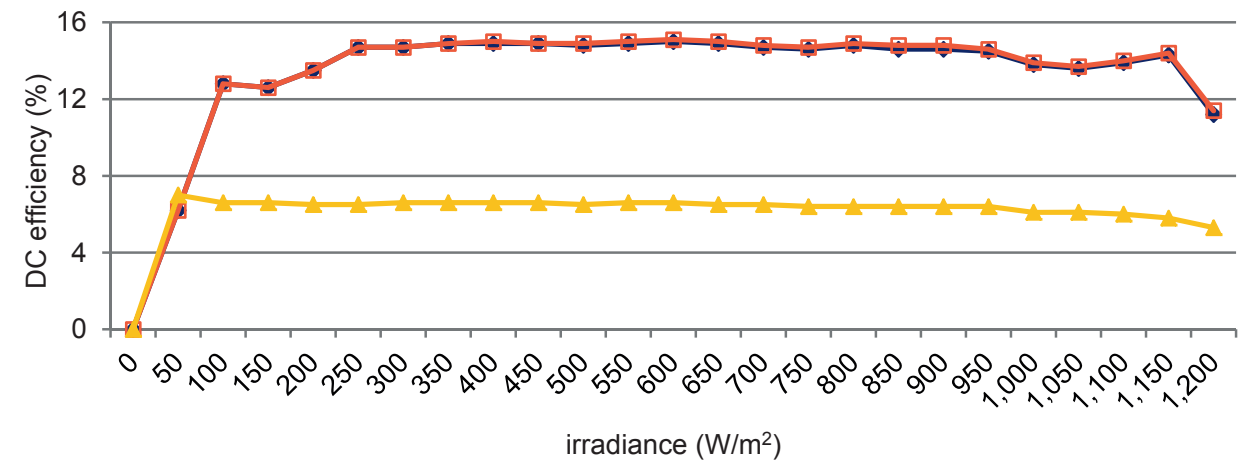

$\multimap$ STP $1 \multimap$ STP2 $\longleftarrow$ SMC

Fig. C.23.Average, temperature-corrected DC-efficiency as function of the irradiance per range of 50 $\mathrm{W} / \mathrm{m}^{2}$ for the month December 2013. 


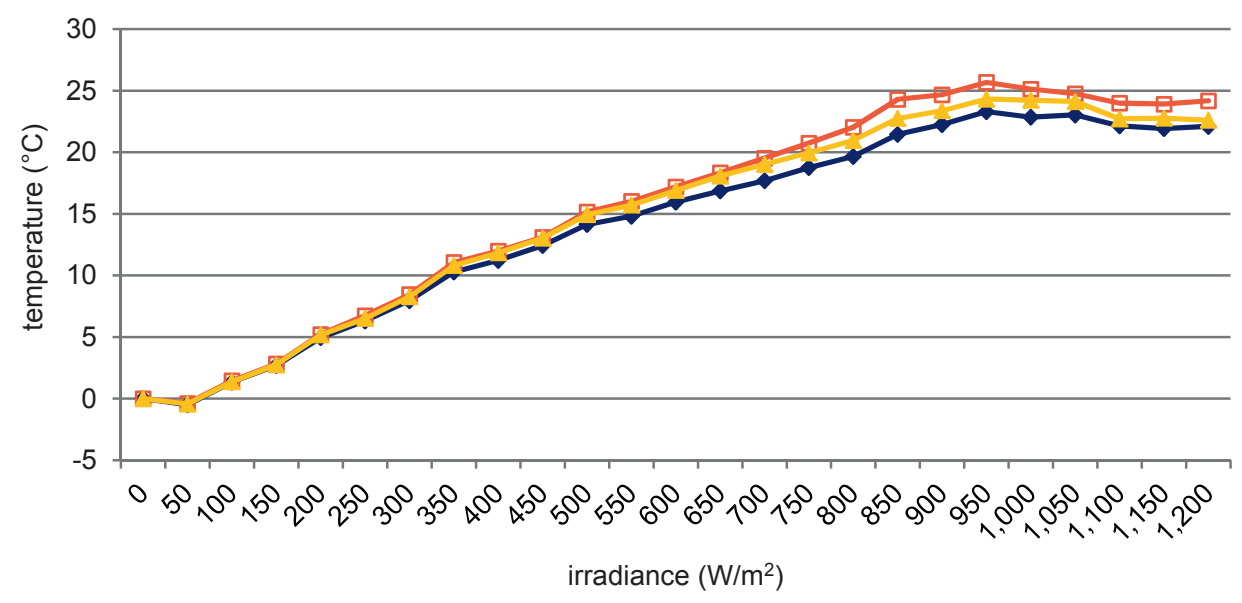

$\longrightarrow \mathrm{Tm}-\mathrm{x}, 1 \longrightarrow \mathrm{Tm}-\mathrm{x}, 2 \longrightarrow \mathrm{Tm}-\mathrm{a}$

Fig. C.24.Difference in temperature between ambient and PV module temperatures as function of the irradiance per range of $50 \mathrm{~W} / \mathrm{m}^{2}$ for December 2013.

TABLE C-23: ENERGY YIELDS OF DIFFERENT SUBSYSTEMS FOR DECEMBER 2013

\begin{tabular}{|c|c|c|c|c|c|c|c|}
\hline PV array & $\begin{array}{r}\text { MF } \\
\%\end{array}$ & $\begin{array}{r}\text { BF } \\
\%\end{array}$ & $\begin{array}{r}\mathrm{H}_{\mathrm{i}, \mathrm{u}} \\
\mathrm{kW} / \mathrm{h} / \mathrm{m}^{2}\end{array}$ & $\begin{array}{l}E_{A, D L} \\
k W h\end{array}$ & $\begin{array}{l}E_{A, W B} \\
k W h\end{array}$ & $\begin{array}{r}E_{F I} \\
\mathrm{kWh}\end{array}$ & $\begin{array}{r}\mathrm{E}_{\mathrm{LT}} \\
\mathrm{kWh}\end{array}$ \\
\hline STP1 & \multirow{3}{*}{81} & 93 & 103 & \multirow{2}{*}{1,009} & 1,056 & 1,019 & 90 \\
\hline STP2 & & 93 & 103 & & 1,050 & 1,018 & 96 \\
\hline SMC & & 93 & 103 & 732 & 727 & 692 & 32 \\
\hline Involar & 81 & 93 & 103 & 145 & - & - & 14 \\
\hline
\end{tabular}

TABLE C-24: KeY FIGURES OF DIFFERENT SUBSYSTEMS FOR DECEMBER 2013

\begin{tabular}{lrrrrrr}
\hline \multirow{2}{*}{ PV array } & $\boldsymbol{\eta}_{\mathrm{dc}}$ & $\boldsymbol{\eta}_{\mathrm{dc}, 25}$ & $\begin{array}{r}\boldsymbol{\eta}_{\text {inv }} \\
\%\end{array}$ & $\begin{array}{r}\boldsymbol{\eta}_{\text {sys }} \\
\%\end{array}$ & $\begin{array}{r}\text { PR } \\
\%\end{array}$ & $\begin{array}{r}\text { PR } \\
\%\end{array}$ \\
\hline STP1 & 13.3 & 14.5 & 96.5 & 13.5 & 82.2 & - \\
\hline STP2 & 13.3 & 14.5 & 97.0 & 13.5 & 82.2 & - \\
\hline SMC & 6.2 & 6.5 & 95.2 & 5.9 & 93.1 & $77.5^{*}$ \\
\hline Involar & - & - & - & 8.0 & 48.7 & $62.6^{+}$ \\
\hline
\end{tabular}

"If PR of SMC is based on $120 \mathrm{~W}_{\mathrm{p}}$ (initial) instead of $100 \mathrm{~W}_{\mathrm{p}}$ (stabilized) PV modules.

+If all errors are due to grid instability. 


\section{C.10 January 2014}

In Table C-25 metadata about the monitoring data are shown.

TABLE C-25: METADATA JANUARY 2014

\begin{tabular}{llrr}
\hline Device & Period & Records & Recording interval \\
\hline Data logger & $01-01-2014-31-01-2014$ & 43,336 & 1 minute \\
\hline WebBox & $01-01-2014-31-01-2014$ & 4,310 & 5 minutes \\
\hline
\end{tabular}

In Fig. C.25 the inverter efficiencies are shown for the STP1, STP2 and SMC PV array. In Fig. C.26 the temperature-corrected DC-efficiencies of the SMA inverters are shown. Records with an irradiance exceeding $1,200 \mathrm{kWh}$ are excluded from this figure, since these values are disputable. In total 33 records are left out.

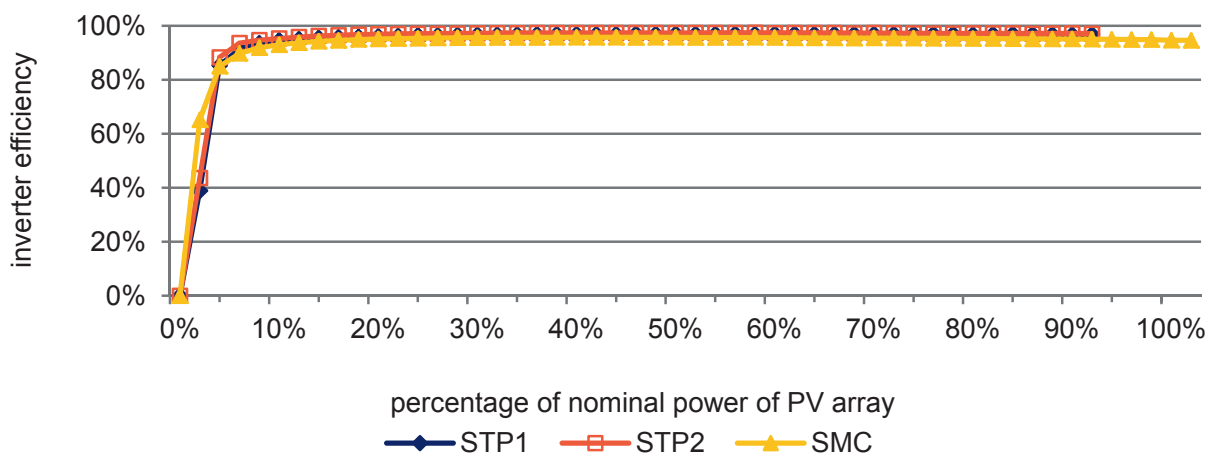

Fig. C.25.Inverter efficiency (\%) of the STP1, STP2 and SMC PV array as function of the array power for the month January 2014. Calculated for 50 linear divided power classes, based on measurements from the WebBox.

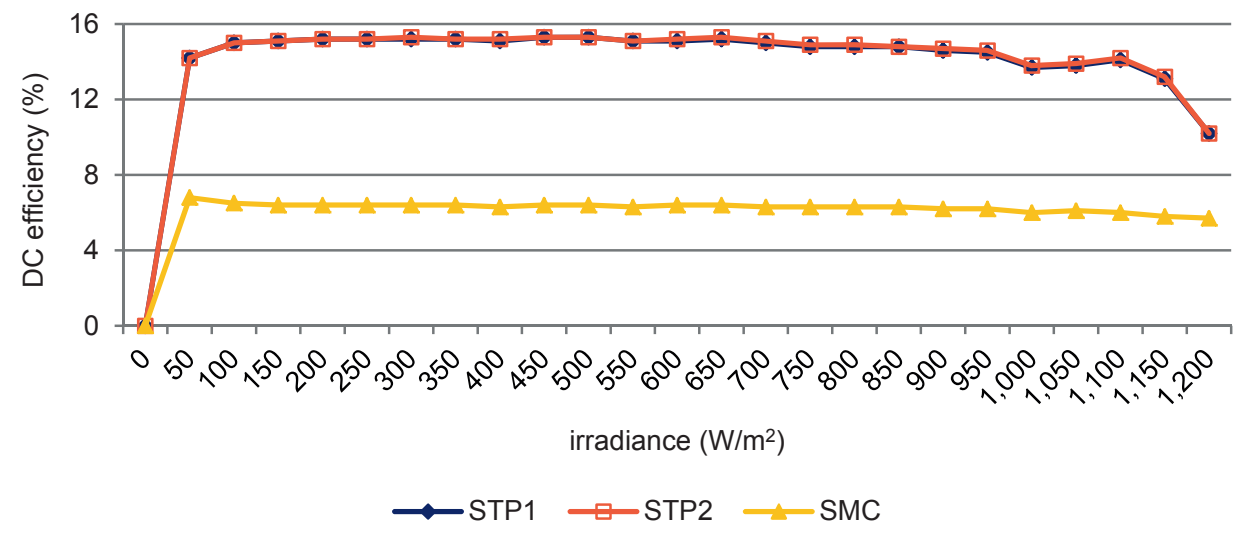

Fig. C.26.Average, temperature-corrected DC-efficiency as function of the irradiance per range of 50 $\mathrm{W} / \mathrm{m}^{2}$ for the month January 2014. 


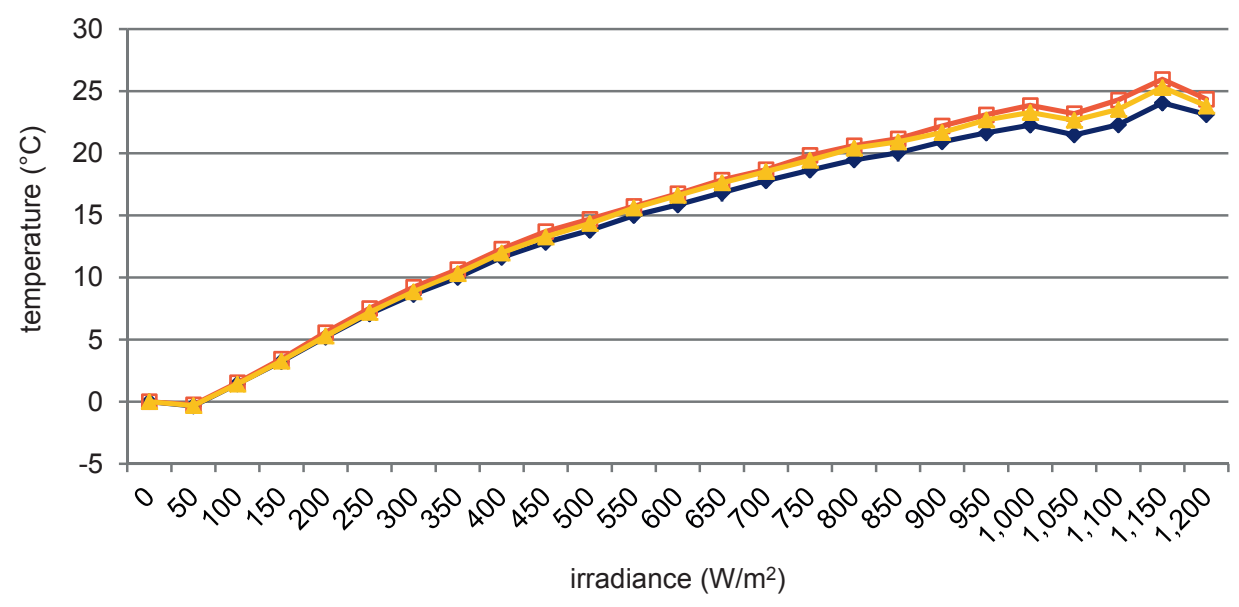

$\longrightarrow$ Tm-x,1 $\longrightarrow$ Tm-x,2 $\longrightarrow$ Tm-a

Fig. C.27.Difference in temperature between ambient and PV module temperatures as function of the irradiance per range of $50 \mathrm{~W} / \mathrm{m}^{2}$ for January 2014 .

TABLE C-26: ENERGY YIELDS OF DIFFERENT SUBSYSTEMS FOR JANUARY 2014

\begin{tabular}{|c|c|c|c|c|c|c|c|}
\hline PV array & $\begin{array}{r}\text { MF } \\
\%\end{array}$ & $\begin{array}{r}\text { BF } \\
\%\end{array}$ & $\begin{array}{r}\mathrm{H}_{\mathrm{i}, \mathrm{u}} \\
\mathrm{kWh} / \mathrm{m}^{2}\end{array}$ & $\begin{array}{l}E_{A, D L} \\
k W h\end{array}$ & $\begin{array}{l}\mathrm{E}_{\mathrm{A}, \mathrm{WB}} \\
\mathrm{kWh}\end{array}$ & $\begin{array}{r}E_{F I} \\
\mathrm{kWh}\end{array}$ & $\begin{array}{r}\mathrm{E}_{\mathrm{LT}} \\
\mathrm{kWh}\end{array}$ \\
\hline STP1 & \multirow{3}{*}{97} & 93 & 110 & \multirow{2}{*}{1,130} & 1,141 & 1,101 & 87 \\
\hline STP2 & & 93 & 110 & & 1,136 & 1,102 & 91 \\
\hline SMC & & 94 & 110 & 773 & 768 & 731 & 30 \\
\hline Involar & 97 & 94 & 110 & 179 & - & - & 14 \\
\hline
\end{tabular}

TABLE C-27: KEY FIGURES OF DIFFERENT SUBSYSTEMS FOR JANUARY 2014

\begin{tabular}{lrrrrrr}
\hline PV array & $\begin{array}{r}\boldsymbol{\eta}_{\text {dc }} \\
\%\end{array}$ & $\begin{array}{r}\boldsymbol{\eta}_{\text {dc,25 }} \\
\%\end{array}$ & $\begin{array}{r}\boldsymbol{\eta}_{\text {inv }} \\
\%\end{array}$ & $\begin{array}{r}\boldsymbol{\eta}_{\text {sys }} \\
\%\end{array}$ & $\begin{array}{r}\text { PR } \\
\%\end{array}$ & $\begin{array}{r}\text { PR } \\
\%\end{array}$ \\
\hline STP1 & 13.8 & 14.9 & 96.5 & 13.7 & 83.3 & - \\
\hline STP2 & 13.8 & 14.9 & 97.0 & 13.7 & 83.4 & - \\
\hline SMC & 6.1 & 6.3 & 95.3 & 5.9 & 92.2 & $76.8^{*}$ \\
\hline Involar & - & - & - & 9.2 & 55.9 & $67.9^{+}$ \\
\hline
\end{tabular}

"If PR of SMC is based on $120 \mathrm{~W}_{\mathrm{p}}$ (initial) instead of $100 \mathrm{~W}_{\mathrm{p}}$ (stabilized) PV modules.

+If all errors are due to grid instability. 


\section{C.11 February 2014}

In Table C-28 metadata about the monitoring data are shown.

TABLE C-28: METADATA FebRUary 2014

\begin{tabular}{llrr}
\hline Device & Period & Records & Recording interval \\
\hline Data logger & $01-02-2014-28-02-2014$ & 29,018 & 1 minute \\
\hline WebBox & $01-02-2014-28-02-2014$ & 3,822 & 5 minutes \\
\hline
\end{tabular}

In Fig. C.28 the inverter efficiencies are shown for the STP1, STP2 and SMC PV array. In Fig. C.29 the temperature-corrected DC-efficiencies of the SMA inverters are shown. Records with an irradiance exceeding $1,200 \mathrm{kWh}$ are excluded from this figure, since these values are disputable. In total 23 records are left out.

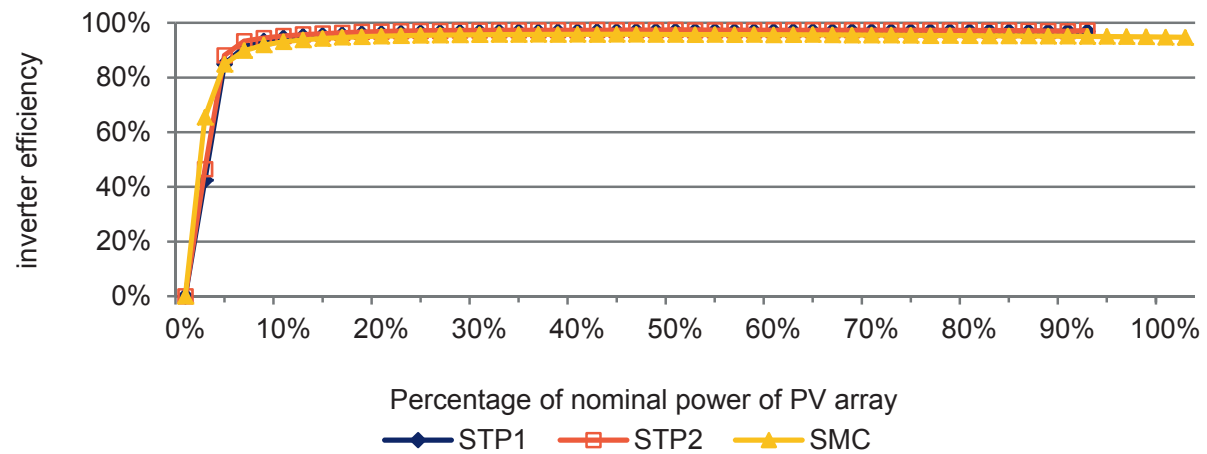

Fig. C.28.Inverter efficiency (\%) of the STP1, STP2 and SMC PV array as function of the array power for the month February 2014. Calculated for 50 linear divided power classes, based on measurements from the WebBox.

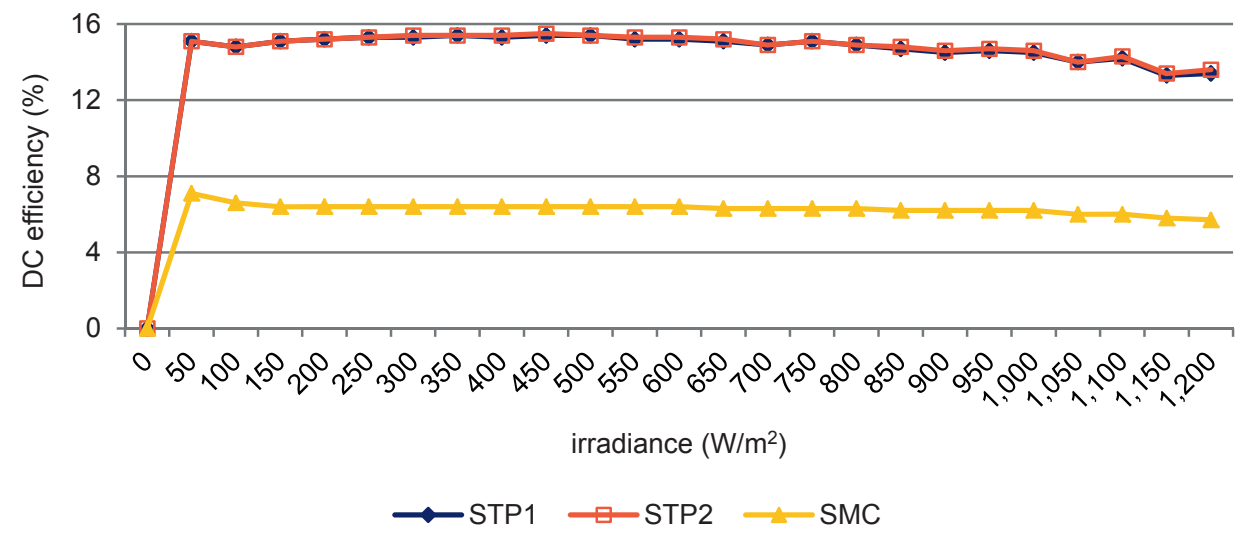

Fig. C.29. Average, temperature-corrected DC-efficiency as function of the irradiance per range of 50 $\mathrm{W} / \mathrm{m}^{2}$ for the month February 2014. 


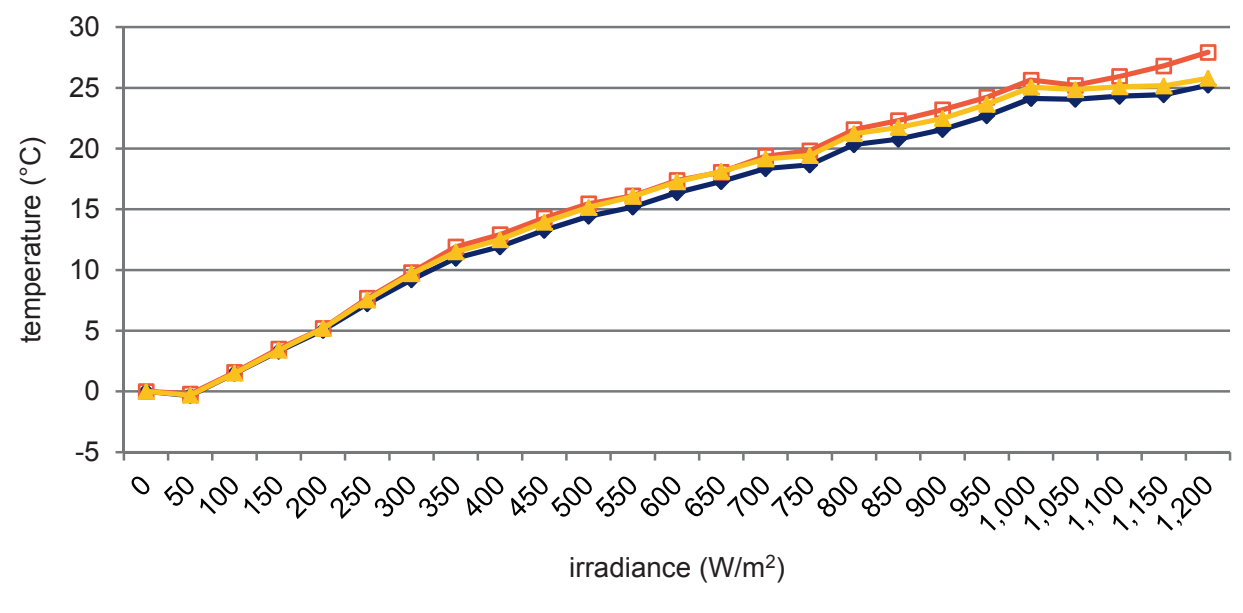

$\longrightarrow$ Tm-x,1 $\because$ Tm-x,2 $\longrightarrow$ Tm-a

Fig. C.30.Difference in temperature between ambient and PV module temperatures as function of the irradiance per range of $50 \mathrm{~W} / \mathrm{m}^{2}$ for February 2014.

TABLE C-29: ENERGY YIELDS OF DIFFERENT SUBSYSTEMS FOR FEBRUARY 2014

\begin{tabular}{|c|c|c|c|c|c|c|c|}
\hline PV array & $\begin{array}{r}\text { MF } \\
\%\end{array}$ & $\begin{array}{r}\mathrm{BF} \\
\%\end{array}$ & $\begin{array}{r}\mathrm{H}_{\mathrm{i}, \mathrm{u}} \\
\mathrm{kWh} / \mathrm{m}^{2}\end{array}$ & $\begin{array}{l}\mathrm{E}_{\mathrm{A}, \mathrm{DL}} \\
\mathrm{kWh}\end{array}$ & $\begin{array}{l}E_{A, W B} \\
k W h\end{array}$ & $\begin{array}{r}E_{F I} \\
k W h\end{array}$ & $\begin{array}{r}E_{L 1} \\
k W h\end{array}$ \\
\hline STP1 & \multirow{3}{*}{72} & 92 & 93 & \multirow{2}{*}{932} & 937 & 905 & 88 \\
\hline STP2 & & 92 & 93 & & 933 & 905 & 92 \\
\hline SMC & & 92 & 93 & 641 & 636 & 605 & 30 \\
\hline Involar & 72 & 92 & 93 & 142 & - & - & 14 \\
\hline
\end{tabular}

TABLE C-30: KEY FIGURES OF DIFFERENT SUBSYSTEMS FOR FEBRUARY 2014

\begin{tabular}{lrrrrrr}
\hline PV array & $\boldsymbol{\eta}_{\mathrm{dc}}$ & $\boldsymbol{\eta}_{\mathrm{dc}, 25}$ & $\begin{array}{r}\boldsymbol{\eta}_{\text {inv }} \\
\%\end{array}$ & $\begin{array}{r}\boldsymbol{\eta}_{\text {sys }} \\
\%\end{array}$ & $\begin{array}{r}\text { PR } \\
\%\end{array}$ & $\begin{array}{r}\text { PR } \\
\%\end{array}$ \\
\hline STP1 & 13.5 & 14.8 & 96.6 & 13.3 & 81.1 & - \\
\hline STP2 & 13.5 & 14.9 & 97.0 & 13.3 & 81.1 & - \\
\hline SMC & 6.0 & 6.3 & 95.3 & 5.7 & 90.5 & $75.4^{*}$ \\
\hline Involar & - & - & - & 8.6 & 52.5 & $61.3^{+}$ \\
\hline
\end{tabular}

"If PR of SMC is based on $120 \mathrm{~W}_{\mathrm{p}}$ (initial) instead of $100 \mathrm{~W}_{\mathrm{p}}$ (stabilized) PV modules.

+If all errors are due to grid instability. 


\section{C.12 March 2014}

In Table C-31 metadata about the monitoring data are shown.

TABLE C-31: METADATA MARCH 2014

\begin{tabular}{llrr}
\hline Device & Period & Records & Recording interval \\
\hline Data logger & $01-03-2014-31-03-2014$ & 43,719 & 1 minute \\
\hline WebBox & $01-03-2014-31-03-2014$ & 4,336 & 5 minutes \\
\hline
\end{tabular}

In Fig. C.31 the inverter efficiencies are shown for the STP1, STP2 and SMC PV array. In Fig. C.32 the temperature-corrected DC-efficiencies of the SMA inverters are shown. Records with an irradiance exceeding $1,200 \mathrm{kWh}$ are excluded from this figure, since these values are disputable. In total 34 records are left out.

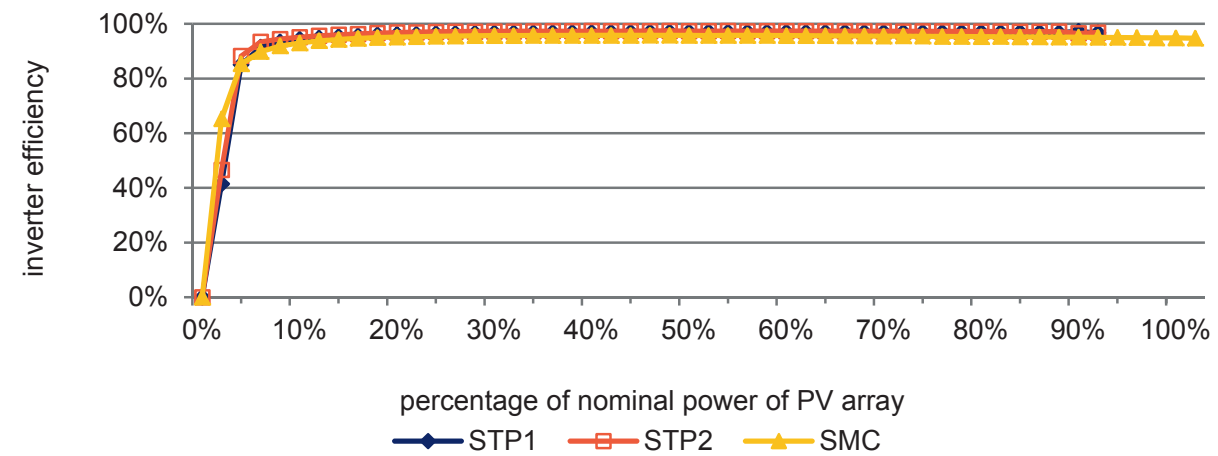

Fig. C.31.Inverter efficiency (\%) of the STP1, STP2 and SMC PV array as function of the array power for the month March 2014. Calculated for 50 linear divided power classes, based on measurements from the WebBox.

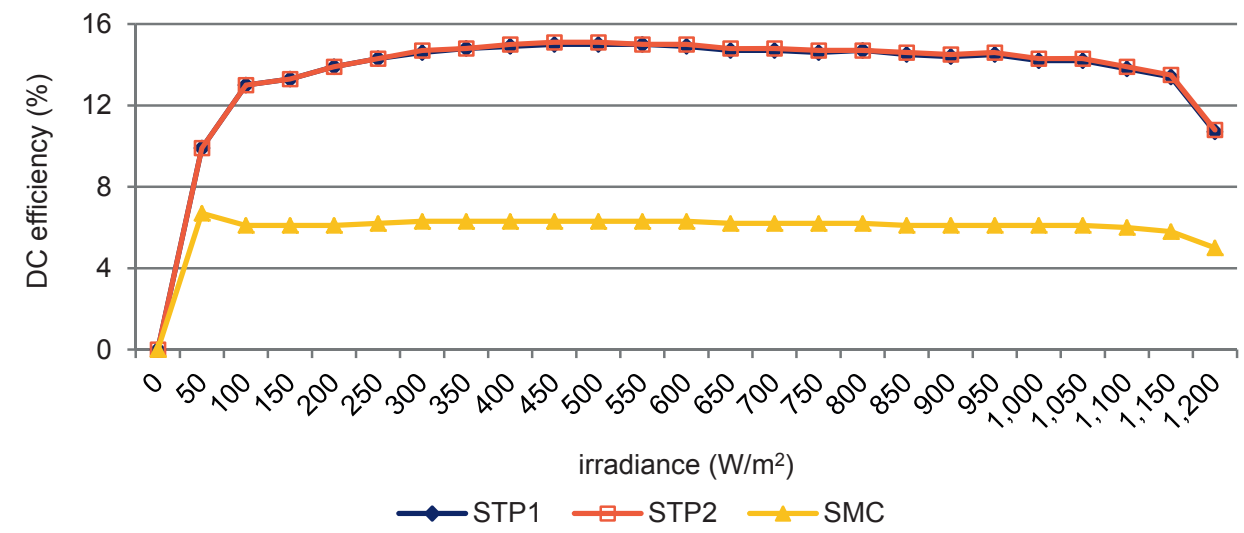

Fig. C.32.Average, temperature-corrected DC-efficiency as function of the irradiance per range of 50 $\mathrm{W} / \mathrm{m}^{2}$ for the month March 2014. 


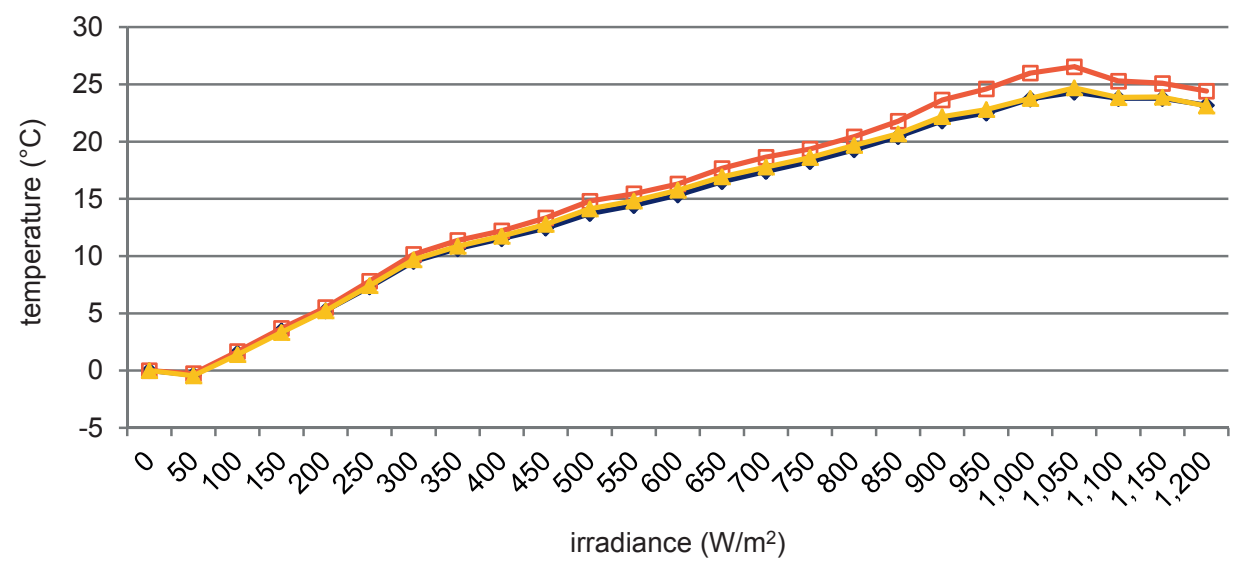

$\longrightarrow \mathrm{Tm}-\mathrm{x}, 1 \longrightarrow \mathrm{Tm}-\mathrm{x}, 2 \longrightarrow \mathrm{Tm}-\mathrm{a}$

Fig. C.33. Difference in temperature between ambient and PV module temperatures as function of the irradiance per range of $50 \mathrm{~W} / \mathrm{m}^{2}$ for March 2014 .

TABLE C-32: ENERGY YIELDS OF DIFFERENT SUBSYSTEMS FOR MARCH 2014

\begin{tabular}{|c|c|c|c|c|c|c|c|}
\hline PV array & $\begin{array}{r}\text { MF } \\
\%\end{array}$ & $\begin{array}{r}\mathrm{BF} \\
\%\end{array}$ & $\begin{array}{r}\mathrm{H}_{\mathrm{i}, \mathrm{u}} \\
\mathrm{kWh} / \mathrm{m}^{2}\end{array}$ & $\begin{array}{l}E_{A, D L} \\
k W h\end{array}$ & $\begin{array}{l}E_{A, W B} \\
k W h\end{array}$ & $\begin{array}{r}\mathrm{E}_{\mathrm{FI}} \\
\mathrm{kWh}\end{array}$ & $\begin{array}{r}E_{L T} \\
k W h\end{array}$ \\
\hline STP1 & \multirow{3}{*}{98} & 93 & 131 & \multirow{2}{*}{1,348} & 1,329 & 1,284 & 123 \\
\hline STP2 & & 93 & 131 & & 1,325 & 1,286 & 130 \\
\hline SMC & & 94 & 131 & 937 & 884 & 843 & 41 \\
\hline Involar & 98 & 94 & 131 & 213 & - & - & 20 \\
\hline
\end{tabular}

TABLE C-33: KEY FIGURES OF DIFFERENT SUBSYSTEMS FOR MARCH 2014

\begin{tabular}{lrrrrrr}
\hline PV array & $\begin{array}{rrrrr}\boldsymbol{\eta}_{\mathrm{dc}} \\
\%\end{array}$ & $\begin{array}{r}\boldsymbol{\eta}_{\mathrm{dc}, 25} \\
\%\end{array}$ & $\begin{array}{r}\boldsymbol{\eta}_{\text {inv }} \\
\%\end{array}$ & $\begin{array}{r}\boldsymbol{\eta}_{\text {sys }} \\
\%\end{array}$ & $\begin{array}{r}\text { PR } \\
\%\end{array}$ & $\begin{array}{r}\text { PR } \\
\%\end{array}$ \\
\hline STP1 & 13.2 & 14.4 & 96.6 & 13.4 & 81.6 & - \\
\hline STP2 & 13.2 & 14.5 & 97.0 & 13.4 & 81.7 & - \\
\hline SMC & 5.9 & 6.2 & 95.3 & 5.7 & 89.3 & $74.4^{*}$ \\
\hline Involar & - & - & - & 8.7 & 52.9 & $62.4^{+}$ \\
\hline
\end{tabular}

"If PR of SMC is based on $120 \mathrm{~W}_{\mathrm{p}}$ (initial) instead of $100 \mathrm{~W}_{\mathrm{p}}$ (stabilized) PV modules.

+If all errors are due to grid instability. 


\section{C.13 April 2014}

In Table C-34 metadata about the monitoring data are shown.

TABLE C-34: METADATA APRIL 2014

\begin{tabular}{llrr}
\hline Device & Period & Records & Recording interval \\
\hline Data logger & $01-04-2014-16-04-2014$ & 26,616 & 1 minute \\
\hline WebBox & $01-04-2014-30-04-2014$ & 4,015 & 5 minutes \\
\hline
\end{tabular}

In Fig. C.34the inverter efficiencies are shown for the STP1, STP2 and SMC PV array. In Fig. C. 35 the temperature-corrected DC-efficiencies of the SMA inverters are shown. Records with an irradiance exceeding $1,200 \mathrm{kWh}$ are excluded from this figure, since these values are disputable. In total 39 records are left out.

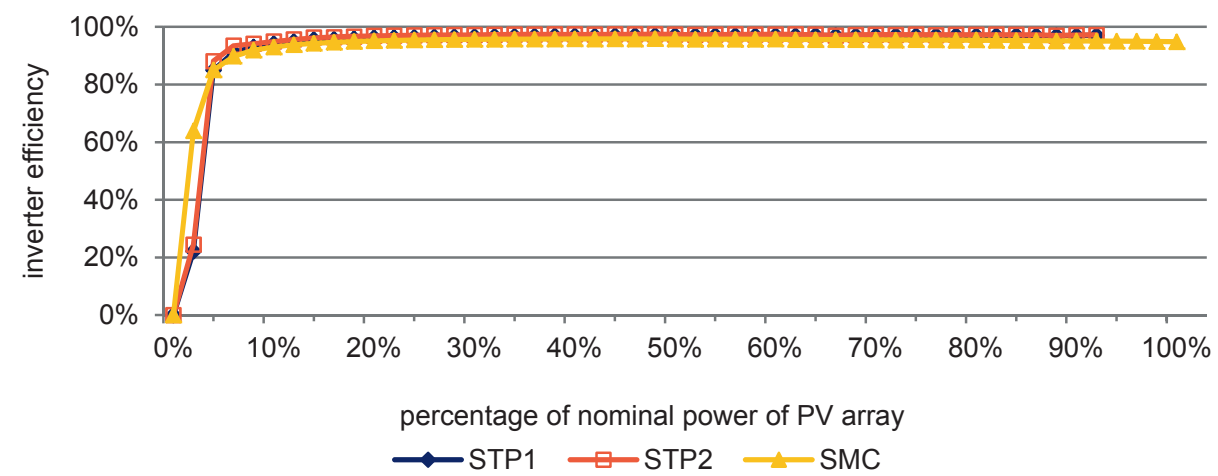

Fig. C.34.Inverter efficiency (\%) of the STP1, STP2 and SMC PV array as function of the array power for the month April 2014. Calculated for 50 linear divided power classes, based on measurements from the WebBox.

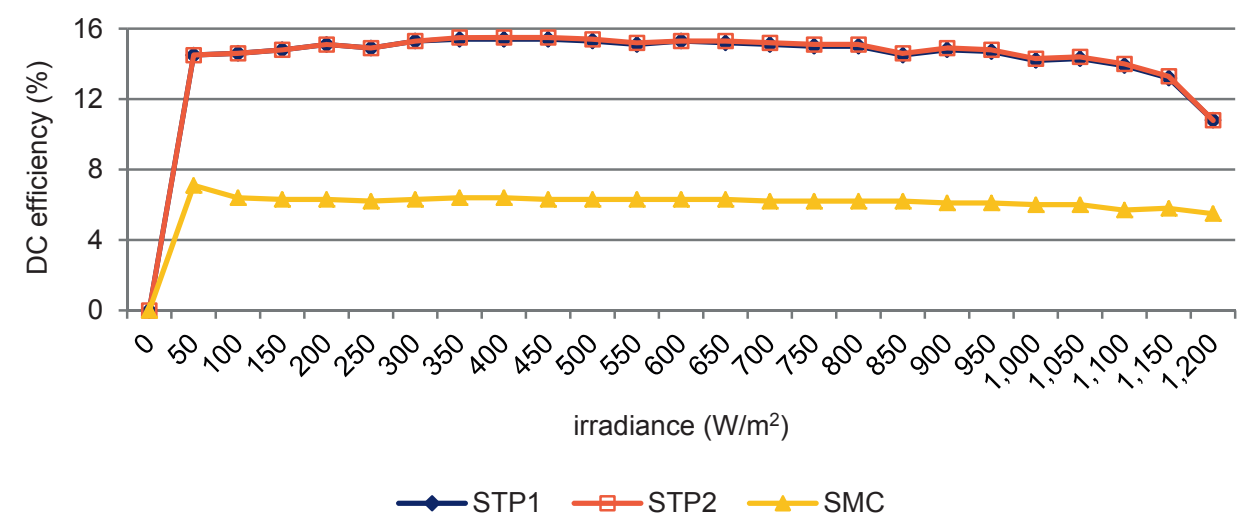

Fig. C.35.Average, temperature-corrected DC-efficiency as function of the irradiance per range of 50 $\mathrm{W} / \mathrm{m}^{2}$ for the month April 2014. 


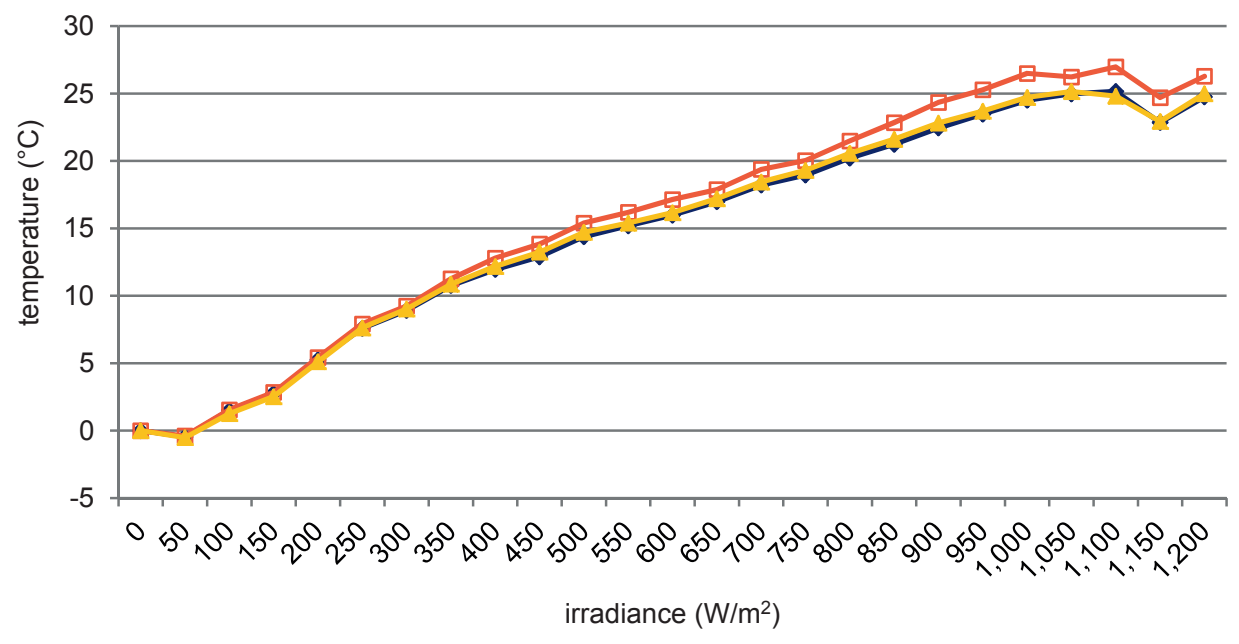

$\longrightarrow \mathrm{Tm}-\mathrm{x}, 1 \longrightarrow \mathrm{Tm}-\mathrm{x}, 2 \longrightarrow \mathrm{Tm}-\mathrm{a}$

Fig. C.36.Difference in temperature between ambient and PV module temperatures as function of the irradiance per range of $50 \mathrm{~W} / \mathrm{m}^{2}$ for April 2014.

TABLE C-35: ENERGY YIELDS OF DIFFERENT SUBSYSTEMS FOR APRIL 2014

\begin{tabular}{|c|c|c|c|c|c|c|c|}
\hline PV array & $\begin{array}{r}\text { MF } \\
\%\end{array}$ & $\begin{array}{r}\mathrm{BF} \\
\%\end{array}$ & $\begin{array}{r}\mathrm{H}_{\mathrm{i}, \mathrm{u}} \\
\mathrm{kWh} / \mathrm{m}^{2}\end{array}$ & $\begin{array}{l}\mathrm{E}_{\mathrm{A}, \mathrm{DL}} \\
\mathrm{kWh}\end{array}$ & $\begin{array}{l}E_{A, W B} \\
k W h\end{array}$ & $\begin{array}{r}\mathrm{E}_{\mathrm{FI}} \\
\mathrm{kWh}\end{array}$ & $\begin{array}{r}\mathrm{E}_{\mathrm{LT}} \\
\mathrm{kWh}\end{array}$ \\
\hline STP1 & \multirow{3}{*}{62} & 90 & 70 & 746 & 654 & 630 & 66 \\
\hline STP2 & & 90 & 70 & & 653 & 632 & 70 \\
\hline SMC & & 91 & 71 & 507 & 454 & 432 & 22 \\
\hline Involar & 62 & 91 & 71 & 127 & - & - & 12 \\
\hline
\end{tabular}

TABLE C-36: KEY FIGURES OF DIFFERENT SUBSYSTEMS FOR APRIL 2014

\begin{tabular}{lrrrrrr}
\hline PV array & $\begin{array}{r}\boldsymbol{\eta}_{\mathrm{dc}} \\
\%\end{array}$ & $\begin{array}{r}\boldsymbol{\eta}_{\mathrm{dc}, 25} \\
\%\end{array}$ & $\begin{array}{r}\boldsymbol{\eta}_{\text {inv }} \\
\%\end{array}$ & $\begin{array}{r}\boldsymbol{\eta}_{\text {sys }} \\
\%\end{array}$ & $\begin{array}{r}\text { PR } \\
\%\end{array}$ & $\begin{array}{r}\text { PR } \\
\%\end{array}$ \\
\hline STP1 & 13.6 & 14.8 & 96.4 & 12.3 & 74.7 & - \\
\hline STP2 & 13.6 & 14.9 & 96.9 & 12.3 & 74.9 & - \\
\hline SMC & 5.9 & 6.2 & 95.2 & 5.4 & 85.0 & $70.8^{*}$ \\
\hline Involar & - & - & - & 9.7 & 58.9 & $66.1^{+}$ \\
\hline
\end{tabular}

"If PR of SMC is based on $120 \mathrm{~W}_{\mathrm{p}}$ (initial) instead of $100 \mathrm{~W}_{\mathrm{p}}$ (stabilized) PV modules.

+If all errors are due to grid instability. 


\section{C.14 STP1}

TABLE C-37: ENERGY YIELDS STP1

\begin{tabular}{lrrrrrrr}
\hline Month & $\begin{array}{r}\text { MF } \\
\%\end{array}$ & $\begin{array}{r}\mathrm{BF} \\
\%\end{array}$ & $\begin{array}{r}\mathrm{H}_{\mathrm{i}, \mathrm{u}} \\
\mathrm{kWh} / \mathrm{m}^{2}\end{array}$ & $\begin{array}{r}\mathrm{E}_{\mathrm{A}, \mathrm{DL}} \\
\mathrm{kWh}\end{array}$ & $\begin{array}{r}\mathrm{E}_{\mathrm{A}, \mathrm{WB}} \\
\mathbf{k W h}\end{array}$ & $\begin{array}{r}\mathrm{E}_{\mathrm{FI}} \\
\mathbf{k W h}\end{array}$ & $\begin{array}{r}\mathrm{E}_{\mathrm{LT}} \\
\mathbf{k W h}\end{array}$ \\
\hline May-13 & 96 & 95 & 144 & 1,532 & 1,449 & 1,401 & 148 \\
\hline Jun-13 & 98 & 99 & 54 & 1,342 & 557 & 538 & 125 \\
\hline Jul-13 & 100 & 95 & 124 & 1,352 & 1,264 & 1,221 & 119 \\
\hline Aug-13 & 100 & 92 & 137 & 1,579 & 1,373 & 1,328 & 147 \\
\hline Sep-13 & 98 & 90 & 145 & 1,235 & 1,208 & 1,166 & 117 \\
\hline Oct-13 & 98 & 90 & 136 & 1,031 & 1,018 & 979 & 95 \\
\hline Nov-13 & 96 & 91 & 123 & 1,227 & 1,211 & 1,169 & 111 \\
\hline Dec-13 & 81 & 93 & 103 & 1,009 & 1,056 & 1,019 & 90 \\
\hline Jan-14 & 97 & 93 & 110 & 1,130 & 1,141 & 1,101 & 87 \\
\hline Feb-14 & 72 & 92 & 93 & 932 & 937 & 905 & 88 \\
\hline Mar-14 & 98 & 93 & 131 & 1,348 & 1,329 & 1,284 & 123 \\
\hline Apr-14 & 62 & 90 & 70 & 746 & 654 & 630 & 66 \\
\hline
\end{tabular}

TABLE C-38: KeY FIGURES STP1

\begin{tabular}{lrrrrr}
\hline \multirow{2}{*}{ Month } & $\begin{array}{r}\boldsymbol{\eta}_{\text {dc }} \\
\%\end{array}$ & $\begin{array}{r}\boldsymbol{\eta}_{\text {dc }, 25} \\
\%\end{array}$ & $\begin{array}{r}\boldsymbol{\eta}_{\text {inv }} \\
\%\end{array}$ & $\begin{array}{r}\boldsymbol{\eta}_{\text {sys }} \\
\%\end{array}$ & $\begin{array}{r}\text { PR } \\
\%\end{array}$ \\
\hline May-13 & 13.6 & 14.9 & 96.7 & 13.4 & 81.3 \\
\hline Jun-13 & 14.0 & 15.3 & 96.6 & 13.6 & 82.7 \\
\hline Jul-13 & 13.9 & 15.1 & 96.6 & 13.5 & 82.3 \\
\hline Aug-13 & 13.6 & 14.9 & 96.8 & 13.3 & 80.6 \\
\hline Sep-13 & 10.9 & 12.0 & 96.5 & 11.0 & 67.2 \\
\hline Oct-13 & 9.6 & 10.5 & 96.2 & 9.9 & 60.0 \\
\hline Nov-13 & 12.9 & 14.1 & 96.6 & 13.1 & 79.5 \\
\hline Dec-13 & 13.3 & 14.5 & 96.5 & 13.5 & 82.2 \\
\hline Jan-14 & 13.8 & 14.9 & 96.5 & 13.7 & 83.3 \\
\hline Feb-14 & 13.5 & 14.8 & 96.6 & 13.3 & 81.1 \\
\hline Mar-14 & 13.2 & 14.4 & 96.6 & 13.4 & 81.6 \\
\hline Apr-14 & 13.6 & 14.8 & 96.4 & 12.3 & 74.7 \\
\hline
\end{tabular}




\section{C.15 STP2}

TABLE C-39: ENERGY YIELDS STP2

\begin{tabular}{lrrrrrrr}
\hline Month & $\begin{array}{r}\text { MF } \\
\%\end{array}$ & $\begin{array}{r}\mathrm{BF} \\
\%\end{array}$ & $\begin{array}{r}\mathrm{H}_{\mathrm{i}, \mathrm{u}} \\
\mathrm{kWh} / \mathrm{m}^{2}\end{array}$ & $\begin{array}{r}\mathrm{E}_{\mathrm{A}, \mathrm{DL}} \\
\mathrm{kWh}\end{array}$ & $\begin{array}{r}\mathrm{E}_{\mathrm{A}, \mathrm{WB}} \\
\mathbf{k W h}\end{array}$ & $\begin{array}{r}\mathrm{E}_{\mathrm{FI}} \\
\mathrm{kWh}\end{array}$ & $\begin{array}{r}\mathrm{E}_{\mathrm{LT}} \\
\mathrm{kWh}\end{array}$ \\
\hline May-13 & 96 & 95 & 144 & 1,532 & 1,453 & 1,410 & 157 \\
\hline Jun-13 & 98 & 99 & 54 & 1,342 & 560 & 543 & 132 \\
\hline Jul-13 & 100 & 95 & 124 & 1,352 & 1,270 & 1,232 & 125 \\
\hline Aug-13 & 100 & 92 & 137 & 1,579 & 1,371 & 1,332 & 156 \\
\hline Sep-13 & 98 & 90 & 145 & 1,235 & 1,382 & 1,342 & 125 \\
\hline Oct-13 & 98 & 90 & 136 & 1,031 & 627 & 601 & 101 \\
\hline Nov-13 & 96 & 91 & 123 & 1,227 & 1,202 & 1,166 & 118 \\
\hline Dec-13 & 81 & 93 & 103 & 1,009 & 1,050 & 1,018 & 96 \\
\hline Jan-14 & 97 & 93 & 110 & 1,130 & 1,136 & 1,102 & 91 \\
\hline Feb-14 & 72 & 92 & 93 & 932 & 933 & 905 & 92 \\
\hline Mar-14 & 98 & 93 & 131 & 1,348 & 1,325 & 1,286 & 130 \\
\hline Apr-14 & 62 & 90 & 70 & 746 & 653 & 632 & 70 \\
\hline
\end{tabular}

TABLE C-40: KEY FIGURES STP2

\begin{tabular}{lrrrrr}
\hline Month & $\begin{array}{r}\boldsymbol{\eta}_{\text {dc }} \\
\%\end{array}$ & $\begin{array}{r}\boldsymbol{\eta}_{\text {dc, 25 }} \\
\%\end{array}$ & $\begin{array}{r}\boldsymbol{\eta}_{\text {inv }} \\
\%\end{array}$ & $\begin{array}{r}\boldsymbol{\eta}_{\text {sys }} \\
\%\end{array}$ & $\begin{array}{r}\text { PR } \\
\%\end{array}$ \\
\hline May-13 & 13.6 & 15.0 & 97.1 & 13.5 & 81.9 \\
\hline Jun-13 & 14.0 & 15.4 & 97.0 & 13.7 & 83.4 \\
\hline Jul-13 & 13.9 & 15.2 & 97.0 & 13.6 & 83.0 \\
\hline Aug-13 & 13.6 & 14.9 & 97.2 & 13.3 & 80.8 \\
\hline Sep-13 & 10.9 & 12.1 & 97.1 & 12.7 & 77.3 \\
\hline Oct-13 & 9.6 & 10.6 & 96.0 & 6.1 & 36.8 \\
\hline Nov-13 & 12.9 & 14.2 & 97.0 & 13.0 & 79.3 \\
\hline Dec-13 & 13.3 & 14.5 & 97.0 & 13.5 & 82.2 \\
\hline Jan-14 & 13.8 & 14.9 & 97.0 & 13.7 & 83.4 \\
\hline Feb-14 & 13.5 & 14.9 & 97.0 & 13.3 & 81.1 \\
\hline Mar-14 & 13.2 & 14.5 & 97.0 & 13.4 & 81.7 \\
\hline Apr-14 & 13.6 & 14.9 & 96.9 & 12.3 & 74.9 \\
\hline
\end{tabular}




\section{C.16 SMC}

TABLE C-41: ENERGY YIELDS SMC

\begin{tabular}{lrrrrrrr}
\hline Month & $\begin{array}{r}\text { MF } \\
\%\end{array}$ & $\begin{array}{r}\mathrm{BF} \\
\%\end{array}$ & $\begin{array}{r}\mathrm{H}_{\mathrm{i}, \mathrm{u}} \\
\mathrm{kWh} / \mathrm{m}^{2}\end{array}$ & $\begin{array}{r}\mathrm{E}_{\mathrm{A}, \mathrm{DL}} \\
\mathrm{kWh}\end{array}$ & $\begin{array}{r}\mathrm{E}_{\mathrm{A}, \mathrm{WB}} \\
\mathrm{kWh}\end{array}$ & $\begin{array}{r}\mathrm{E}_{\mathrm{FI}} \\
\mathrm{kWh}\end{array}$ & $\begin{array}{r}\mathrm{E}_{\mathrm{LT}} \\
\mathrm{kWh}\end{array}$ \\
\hline May-13 & 96 & 95 & 144 & 1,081 & 1,013 & 964 & 49 \\
\hline Jun-13 & 98 & 99 & 54 & 935 & 385 & 367 & 41 \\
\hline Jul-13 & 100 & 95 & 124 & 933 & 868 & 826 & 38 \\
\hline Aug-13 & 100 & 92 & 137 & 1,082 & 934 & 889 & 48 \\
\hline Sep-13 & 98 & 90 & 145 & 1,009 & 952 & 907 & 46 \\
\hline Oct-13 & 98 & 90 & 136 & 942 & 876 & 834 & 41 \\
\hline Nov-13 & 96 & 91 & 123 & 880 & 836 & 796 & 39 \\
\hline Dec-13 & 81 & 93 & 103 & 732 & 727 & 692 & 32 \\
\hline Jan-14 & 97 & 94 & 110 & 773 & 768 & 731 & 30 \\
\hline Feb-14 & 72 & 92 & 93 & 641 & 636 & 605 & 30 \\
\hline Mar-14 & 98 & 94 & 131 & 937 & 884 & 843 & 41 \\
\hline Apr-14 & 62 & 91 & 71 & 507 & 454 & 432 & 22 \\
\hline
\end{tabular}

TABLE C-42: KeY FIGURES SMC

\begin{tabular}{lrrrrrr}
\hline Month & $\begin{array}{r}\boldsymbol{\eta}_{\text {dc }} \\
\%\end{array}$ & $\begin{array}{r}\boldsymbol{\eta}_{\text {dc,25 }} \\
\%\end{array}$ & $\begin{array}{r}\boldsymbol{\eta}_{\text {inv }} \\
\%\end{array}$ & $\begin{array}{r}\boldsymbol{\eta}_{\text {sys }} \\
\%\end{array}$ & $\begin{array}{r}\text { PR } \\
\%\end{array}$ & $\begin{array}{r}\text { PR_ini } \\
\%\end{array}$ \\
\hline May-13 & 6.2 & 6.5 & 95.2 & 5.9 & 93.3 & 77.7 \\
\hline Jun-13 & 6.3 & 6.6 & 95.3 & 6.0 & 93.9 & 78.3 \\
\hline Jul-13 & 6.2 & 6.4 & 95.2 & 5.9 & 92.8 & 77.3 \\
\hline Aug-13 & 6.0 & 6.3 & 95.2 & 5.7 & 89.9 & 75.0 \\
\hline Sep-13 & 5.8 & 6.0 & 95.2 & 5.5 & 87.1 & 72.6 \\
\hline Oct-13 & 5.7 & 5.9 & 95.2 & 5.4 & 85.2 & 71.0 \\
\hline Nov-13 & 6.0 & 6.2 & 95.2 & 5.7 & 90.1 & 75.1 \\
\hline Dec-13 & 6.2 & 6.5 & 95.2 & 5.9 & 93.1 & 77.5 \\
\hline Jan-14 & 6.1 & 6.3 & 95.3 & 5.9 & 92.2 & 76.8 \\
\hline Feb-14 & 6.0 & 6.3 & 95.3 & 5.7 & 90.5 & 75.4 \\
\hline Mar-14 & 5.9 & 6.2 & 95.3 & 5.7 & 89.3 & 74.4 \\
\hline Apr-14 & 5.9 & 6.2 & 95.2 & 5.4 & 85.0 & 70.8 \\
\hline
\end{tabular}




\section{C.17 Involar}

TABLE C-43: ENERGY YIELDS INVOLAR

\begin{tabular}{lrrrrr}
\hline Month & $\begin{array}{r}\text { MF } \\
\%\end{array}$ & $\begin{array}{r}\text { BF } \\
\%\end{array}$ & $\begin{array}{r}\mathrm{H}_{\mathrm{i}, \mathrm{u}} \\
\mathrm{kWh} / \mathrm{m}^{2}\end{array}$ & $\begin{array}{r}\mathrm{E}_{\mathrm{A}} \\
\mathrm{kWh}\end{array}$ & $\begin{array}{r}\mathrm{E}_{\mathbf{L T}} \\
\mathrm{kWh}\end{array}$ \\
\hline May-13 & 96 & 95 & 144 & 219 & 22 \\
\hline Jun-13 & 98 & 99 & 54 & 190 & 18 \\
\hline Jul-13 & 100 & 95 & 124 & 243 & 22 \\
\hline Aug-13 & 100 & 92 & 137 & 265 & 26 \\
\hline Sep-13 & 98 & 90 & 145 & 240 & 24 \\
\hline Oct-13 & 98 & 90 & 136 & 206 & 19 \\
\hline Nov-13 & 96 & 91 & 123 & 199 & 19 \\
\hline Dec-13 & 81 & 93 & 103 & 145 & 14 \\
\hline Jan-14 & 97 & 94 & 110 & 179 & 14 \\
\hline Feb-14 & 72 & 92 & 93 & 142 & 14 \\
\hline Mar-14 & 98 & 94 & 131 & 213 & 20 \\
\hline Apr-14 & 62 & 91 & 71 & 127 & 12 \\
\hline
\end{tabular}

TABLE C-44: KEY FIGURES INVOLAR

\begin{tabular}{lrrr}
\hline Month & $\begin{array}{r}\boldsymbol{\eta}_{\text {sys }} \\
\%\end{array}$ & $\begin{array}{r}\text { PR } \\
\%\end{array}$ & $\begin{array}{r}\text { PR (no faults) } \\
\%\end{array}$ \\
\hline May-13 & 8.2 & 50.0 & 58.4 \\
\hline Jun-13 & 9.2 & 55.8 & 61.9 \\
\hline Jul-13 & 10.6 & 64.3 & 68.1 \\
\hline Aug-13 & 9.5 & 57.8 & 63.5 \\
\hline Sep-13 & 9.0 & 55.0 & 60.1 \\
\hline Oct-13 & 8.0 & 48.8 & 60.0 \\
\hline Nov-13 & 8.8 & 53.3 & 61.5 \\
\hline Dec-13 & 8.0 & 48.7 & 62.6 \\
\hline Jan-14 & 9.2 & 55.9 & 67.9 \\
\hline Feb-14 & 8.6 & 52.5 & 61.3 \\
\hline Mar-14 & 8.7 & 52.9 & 62.4 \\
\hline Apr-14 & 9.7 & 58.9 & 66.1 \\
\hline
\end{tabular}




\section{VR4PV software in Quest3D}

\section{D.1 Introduction}

During design processes of product-integrated PV (PIPV) and BIPV it is desirable to analyze the availability and intensity of solar irradiance on surfaces of these products and buildings in order to optimally position PV cells or PV modules while including (i) variable irradiance due to curvature, (ii) (self-)shading effects and (iii) effects of movement of the PV product. This can be partly done yet in CAD software in which most products and buildings are designed in the Netherlands. However, previous studies in the field of irradiance simulations in CAD environments [146-148] used software based on the raytracing technique, which gave accurate results, but required much processing time. The rendering of a model would cost about 30 minutes to a couple of hours per scene, depending on the complexity of the geometry, using ray-tracing in 3D Studio Max, a typical render tool for industrial designers.

Ray-tracing is an algorithm that traces the paths of light rays from a light source until it eventually reaches the eye (i.e. camera). From a computational point of view, the algorithm is mostly implemented as backward ray-tracing: starting at the position of the eye, rays are traced until eventually a light source is reached. Ray-tracing enables special effect such as reflections, refractions, shadows and indirect lighting [149].

A study of Kovach and Schmid [146] uses the software tool RADIANCE to calculate the shading losses in PV systems by applying the ray-tracing technique. However, this software is less suitable during a design process, because it is not integrated in a CAD environment. This in contrast to the studies of Reich et al. [147, 148] where irradiance simulation is carried out within a CAD tool, based on the ray-tracing algorithm. However, they found that both methods do not match well with the designers needs during the design process, because rendering of a scene takes too much time and handling of the software is complicated.

There have been several attempts to evaluate shadows caused by obstacles from the environment. Some studies estimate the shadow geometry by (fisheye) photographs [150, 151], others determine irradiance losses due to shadowing by a space angular approach [152]. These methods require optical measurements at the particular location of a PV system and transformation of lens coordinates. Since the space angular approach is valid for one specific position on a PV module only, it is mainly suitable for rough estimations [152]. Various software programs to simulate these shadows are available, however some of these programs lack the option to import 3D CAD models into the tool, which makes this modeling step complicated and time-consuming [153]. Furthermore, some software tools are able to import complex 3D CAD models, but in general these tools are quite extensive and more suited for detailed design [153]. Moreover, the energetic performance of PV systems is not included. 
To decrease the processing time, this study explores a new method based on the rasterization algorithm. Rasterization is the process of decomposing computer graphics into smaller fragments corresponding to pixels on the screen. These fragments consist of a window coordinate, color and other attributes, such as the normal and texture coordinate. The values associated with each fragment are interpolated between the points (i.e. vertices) of the polygon of a 3D mesh that is processed [154]. This method is less accurate and does not allow for special effects like reflection and refraction, however it demands less calculation time than ray-tracing. Depending on several factors (e.g. complexity of the 3D object(s), CPU, GPU) estimated processing time is a factor 0.01 compared to ray-tracing. Therefore one can produce real-time results; actually a sequence of simulations of subsequent scenes can be interpreted like a movie, which is important during the design phase.

The VR4PV has the ability to calculate the irradiance, shading, temperature and the electrical performance of the PV cell. This study focusses on the irradiance component of the tool, since this is the largest contributor to inaccuracy and directly influences the temperature and electrical performance of the PV cell. The goal of this study is to validate a tool based on rasterization in order to classify the accuracy of the simulation when using hourly averaged irradiance data as input for the calculation of irradiance per minute.

\section{D.1.1 Outline}

The structure of this appendix is as follows. First the software will be introduced in more detail. Then the various models regarding (tilted) irradiance, diode modeling, cell temperatures and shadow algorithms which are found in literature and implemented in the VR4PV are presented and evaluated. Subsequently the simulation steps of the tool will be described, followed by the results of a modest validation. The appendix will finish with a discussion and conclusions.

\section{D.2 Software description}

The software tool presented in this study is meant to play a role during the design process of PV products and BIPV and to support the selection of a preliminary layout of PV cells and PV modules in the total design. Besides, the VR4PV can be used to evaluate the product and (self-)shading in a scenario, i.e. in a situation that changes in course of time and in which positions of objects can change. A schematic overview of the VR4PV is shown in Fig. D.1. The blue circles indicate models implemented inside the tool which cannot be adjusted by the user, the green circles indicate input fields and the red ones indicate functions to adjust 3D objects. 


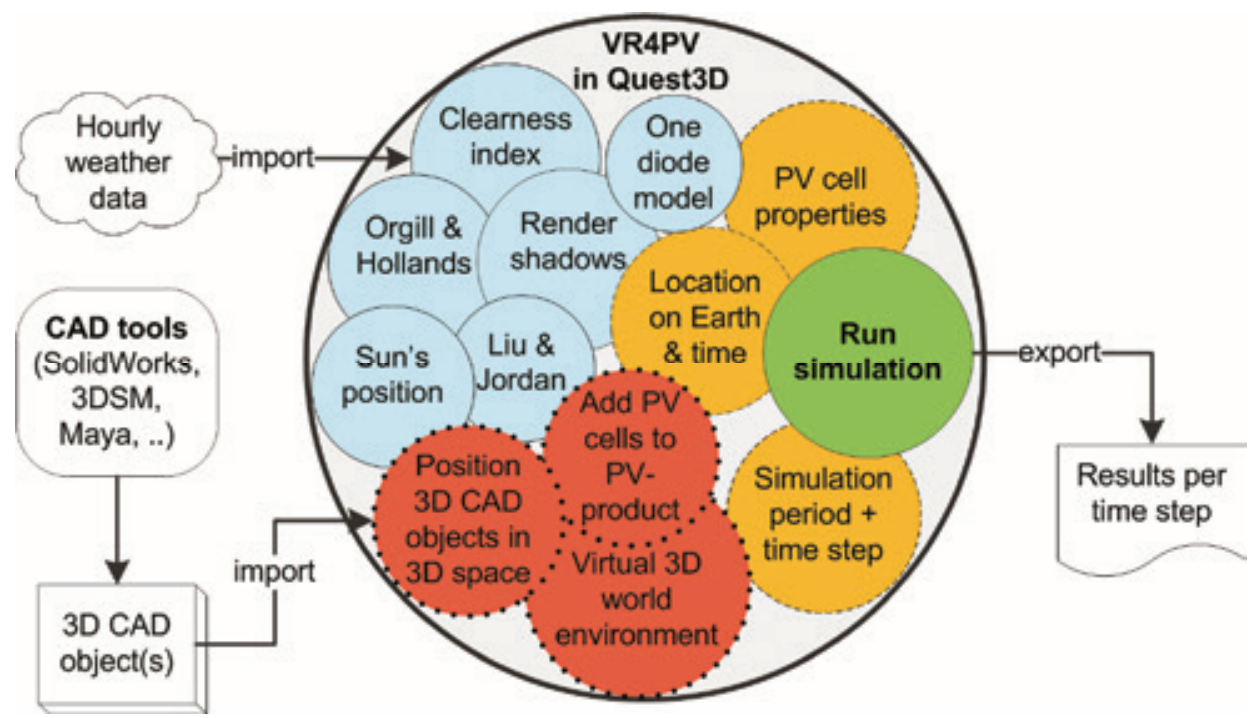

Fig. D.1. Schematic overview of the VR4PV.

As shown, 3D CAD objects are imported into VR4PV together with the hourly weather data of a specific location. Inside the tool it is possible to add PV cells to the imported CAD object, representing the PV product. By clicking on this product, a PV cell is added to the product at the position of the mouse cursor and will be oriented normal to the surface. The PV cell itself has a flat surface. Subsequently the irradiance model calculates the irradiance received by the PV cells, taking direct shadows of the surroundings and the product itself into account.

This approach aims to reduce the time as well as the costs involved in the development of PV products leading to better and cheaper PV products. Instead of producing different prototypes and carrying out expensive measurements to determine the difference yields of the PV cells of each prototype, this process can be carried out in a virtual environment. Another benefit of the opportunity to simulate the yield for various scenarios is that it will probably lead to better PV products in a market with various users and different environments of use.

\section{D.2.1 Quest3D}

In this study, Quest3D [155] is used as the software environment to develop the VR4PV. Quest3D is a real-time software environment based on the rasterization algorithm that has been used so far to create software for internet, simulators and virtual reality applications. Quest3D is an object-oriented programming environment, but instead of writing lines of code, programs in Quest3D are constructed on the basis of building blocks containing methods and related algorithms. These building blocks - so-called channels - are connected to each other to form a channel graph. Because of this structure the software is highly 
modular. Quest3D is suitable for the use of time-based scenario-based evaluations of PV products. In such an evaluation the product is analyzed taking into account, among others, the surroundings and different modes of use or application in course of time. This creates the opportunity to evaluate a product in its real-life environment, often indicated as virtual reality.

\section{D.2.2 Simulation}

To be able to execute a simulation, first a surroundings with $3 \mathrm{D}$ objects must be created in which a product or building with PV cells will be evaluated. This product or this building has to be created using a CAD tool as well and it has to be imported in the 3D surroundings. To be able to calculate time dependent variables, such as solar irradiance, the time period and the time step has to be set, as well as the location on earth. Besides, the corresponding weather data have to be imported. In addition, the electrical and geometrical PV cell parameters can be adjusted to the PV cells that will be investigated.

After the calculations of each time step, the tool outputs the results into an ASCII data file that can be further processed. The flowchart shown in Fig. 6.2 shows the simulation steps inside the VR4PV.

\section{D.2.3 Irradiance on tilted surfaces}

To compute the irradiance received by a surface with an arbitrary tilt angle, various irradiance models can be found in literature that can be distinguished in two categories: isotropic and anisotropic sky models. The Perez model [156] is a widely accepted anisotropic sky model. The Liu-Jordan model [81] is the most commonly used isotropic sky model. The VR4PV converts global horizontal irradiance $G_{h o r}$ to direct $G_{b b}$ and diffuse $G_{d h}$ horizontal irradiance by applying the clearness index $k_{\tau}$ combined with the OrgillHollands relationship [124].

The eccentricity factor $E_{o}$ is calculated by Spencer's Fourier series [157] and is used to calculate the extra-terrestrial irradiance based on the solar constant of $1367 \mathrm{~W} / \mathrm{m}^{2}$.

Subsequently, the Liu-Jordan model is applied to calculate the irradiance on a tilted surface. This approach can be easily implemented in the simulation tool and requires less input data. To estimate the consequences of using the Liu-Jordan model vs. the Perez model this study refers to a study by Santamouris et al. [158]. Eleven isotropic and anisotropic models were evaluated over a period of two years (1984-1986) with measurement data from Cyprus. It was found that the Perez model overestimates and the Liu-Jordan model underestimates measured irradiance values. The average difference between both models is only $5 \%$ which is less than the accuracy of outdoor measurements of irradiance.

The Liu-Jordan model has a good accuracy for low intensities $\left(<300 \mathrm{~W} / \mathrm{m}^{2}\right)$, such values being associated with overcast skies which is quite common in the North West of Europe. 
As skies become clearer, the validity of the isotropic sky model reduces due to the presence of circumsolar and horizon brightening anisotropic effects [159]. The Liu-Jordan model slightly underestimates irradiance at clear and partly cloudy conditions [160].

Additionally the position of the sun is calculated in the VR4PV. The model of BlancoMuriel et al. [161] is implemented, which determines the position of the sun with an accuracy of 0.5 minutes of arc for the period 1999-2015. This model is applied because of its ease of use and its accuracy.

\section{D.2.4 Shadows}

Shaded objects receive less radiation, hence the tool calculates shadows. To compute the shadows, various computer algorithms can be found in literature. The two most common techniques, for software based on the rasterization algorithm, are shadow mapping [162] and the stencil shadow volume technique [163].

The stencil shadow volume algorithm defines a region of space that is in the shadow of a particular occluder with a given light source. It requires knowledge of the polygonal meshes in the scene to calculate the silhouette of each shadow casting object [164]. The basic concept of the stencil shadow algorithm is to use the stencil buffer of the GPU as a masking mechanism to prevent pixels in shadow from being drawn during the rendering pass for a particular light source. This is accomplished by rendering an invisible shadow volume for each shadow-casting object in a scene. Subsequently, only pixels outside these shadow volumes are illuminated [165].

The stencil shadow volume algorithm is implemented in the presented tool to add shadows to the environment, since it is more accurate and the feature is already built-in in Quest3D.

By applying simplified objects for the generation of shadows, the influence of the stencil shadow volume algorithm on the CPU performance is minimal [164].

To show which PV cells are affected by shadows, the scene viewer shows the shape of the shadows casted on each PV cell at the top of the screen. As an example, in Fig. D.2 a screenshot of the tool is shown, the little numbered white squares at the top of the figure represent the PV cells attached to the object at the front; the grey areas in these white squares indicate the shadows received by each PV cell.

If the pixel in the center of a PV cell is grey, thus in shadow, the direct irradiance component of the Liu and Jordan model is excluded from the determination of the irradiance received by this particular PV cell. 


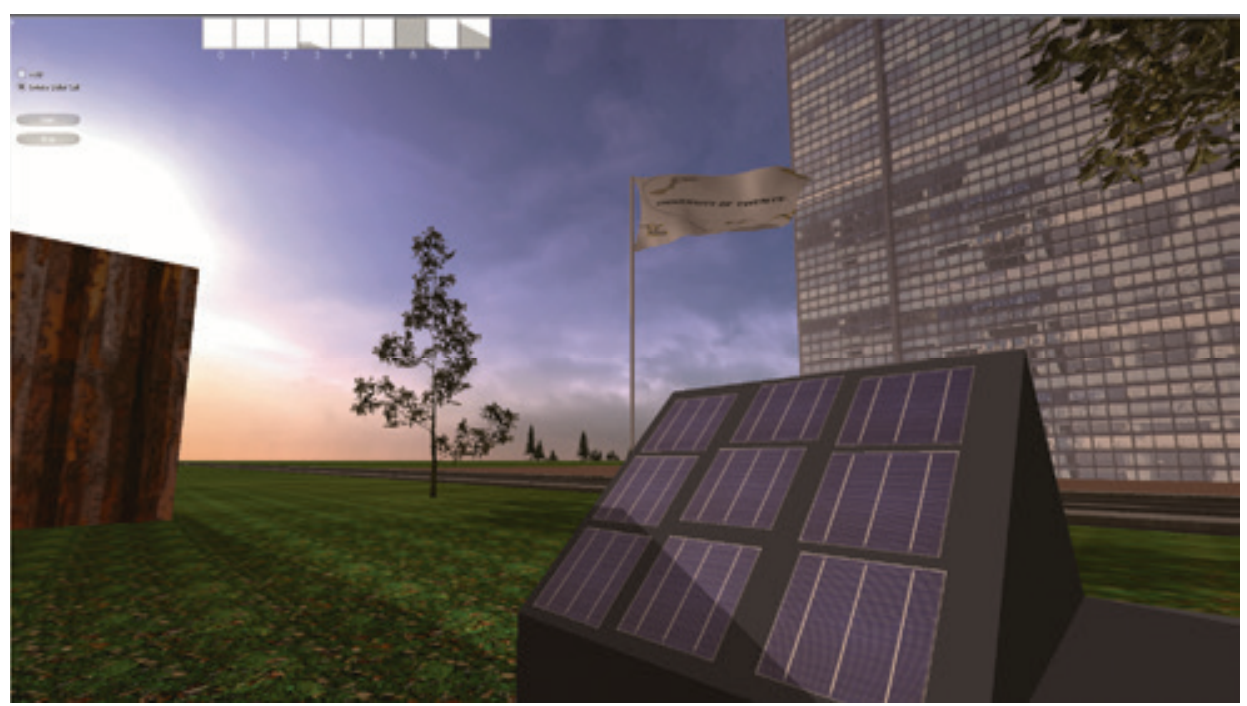

Fig. D.2. Screenshot of the tool during simulation. At the left top all PV cells seen as white squares, grey indicates shaded area.

\section{D.2.5 Time step}

The time step of the simulation can be adjusted to the needs of the user. It is possible to simulate each minute or even each second, in this way the shadows will move slightly in every frame according to the small adjustment of the Sun's position.

In order to get the irradiance at these time steps, a moving average is used, based on the hourly irradiance data.

Because small time steps are allowed, the Liu and Jordan model - which is based on hourly irradiance - will be used on a per-minute basis. This will introduce an error, which will be investigated as well.

\section{D.2.6 Cell temperature}

The VR4PV accounts for the irradiance and temperature dependencies of the cell according to [85]. The relationship used in this study computes the cell temperature based on the irradiance $G_{t}$ received, the ambient temperature $T_{a}$ and the wind speed $V_{f}$, based on a simple semi-empirical correlation proposed by Skoplaki et al. [125]:

$$
T_{c}=T_{a}+\omega\left(\frac{0.32}{8.91+2.0 V_{f}}\right) G_{t}
$$

where $\omega$ is a mounting coefficient.

The selected models found in literature are combined in the VR4PV to evaluate the yield of PV cells for different orientations and tilt angles in an arbitrary $3 \mathrm{D}$ environment. With 
input of time series of local global horizontal irradiance, ambient temperature and wind speed it will be possible to evaluate a PV product at a random location on earth.

\section{D.3 Experimental set-up}

For the validation of the tool, 1-minute irradiance measurements of two different locations are used. The first dataset is achieved from the Measurement and Instrumentation Data Center (MIDC) from the NREL [166]. The location is in Los Angeles, California (Latitude 33.97 North, Longitude 118.42 West) and the measurements of the global horizontal irradiance cover the month of June 2011. A rotating shadow band radiometer is used as measurement device, the data sample rate is every 3 seconds with 1 -minute average output.

The second dataset is from the European Solar Test Installation (ESTI) from the Joint Research Center (JRC) as part of the European Commission [167]. The measurements of the global horizontal irradiance and irradiance on a fixed $30^{\circ}$ tilted plane oriented $8.5^{\circ}$ west from south are carried out in Bolzano, Italy (Latitude 46.46 North, Longitude 11.33 East). The sampling frequency is once per minute. The validation is based on a period from the $6^{\text {th }}$ to the $30^{\text {th }}$ of April 2011.

Two PV cells, one horizontal and the other $30^{\circ}$ tilted and orientated corresponding to the plane in Bolzano, are simulated on the basis of hourly irradiance originating from these datasets, in order to validate the tool.

The errors of the results can be related to three factors:

(a) the assumption of constant irradiance between the average hourly irradiance points

(b) the use of Orgill-Hollands and Liu-Jordan model, and

(c) the use of these hourly irradiance models for the calculation of irradiance per minute.

To evaluate these errors, four simulations are carried out. The investigated error factor(s) are mentioned inside the brackets:

i. Measured hourly averaged horizontal irradiance $\stackrel{V R 4 P V}{\Longrightarrow}$ minutely horizontal irradiance for Los Angeles (a).

ii. Measured hourly averaged horizontal irradiance $\stackrel{V R 4 P V}{\Longrightarrow}$ minutely horizontal and $30^{\circ}$ tilted irradiance for Bolzano ( $\mathrm{a}, \mathrm{b} \& \mathrm{c})$.

iii. Measured minutely horizontal irradiance $\stackrel{V R 4 P V}{\Longrightarrow}$ minutely $30^{\circ}$ tilted irradiance for Bolzano (b \& c).

iv. Measured hourly averaged horizontal irradiance $\stackrel{V R 4 P V}{\Longrightarrow}$ hourly averaged $30^{\circ}$ tilted irradiance $\stackrel{\text { interpolated }}{=}$ minutely $30^{\circ}$ tilted irradiance for Bolzano (a \& b). 
The measured hourly averaged horizontal irradiance is based on the minutely measurements. All the simulation results are compared with the actual measurements per minute.

\section{D.4 Results}

In Fig. D.3 the results of the $1^{\text {st }}$ simulation with the VR4PV are shown. The simulated global horizontal irradiance is plotted against the measured global horizontal irradiance per minute for the location of Los Angeles for the range of $50-1,200 \mathrm{~W} / \mathrm{m}^{2}$. As can be seen, most simulated irradiance points correlate as expected with the measured global horizontal irradiance. Because of the average hourly irradiance used as input, the extreme irradiance values above $1,050 \mathrm{~W} / \mathrm{m}^{2}$ correlate less well.

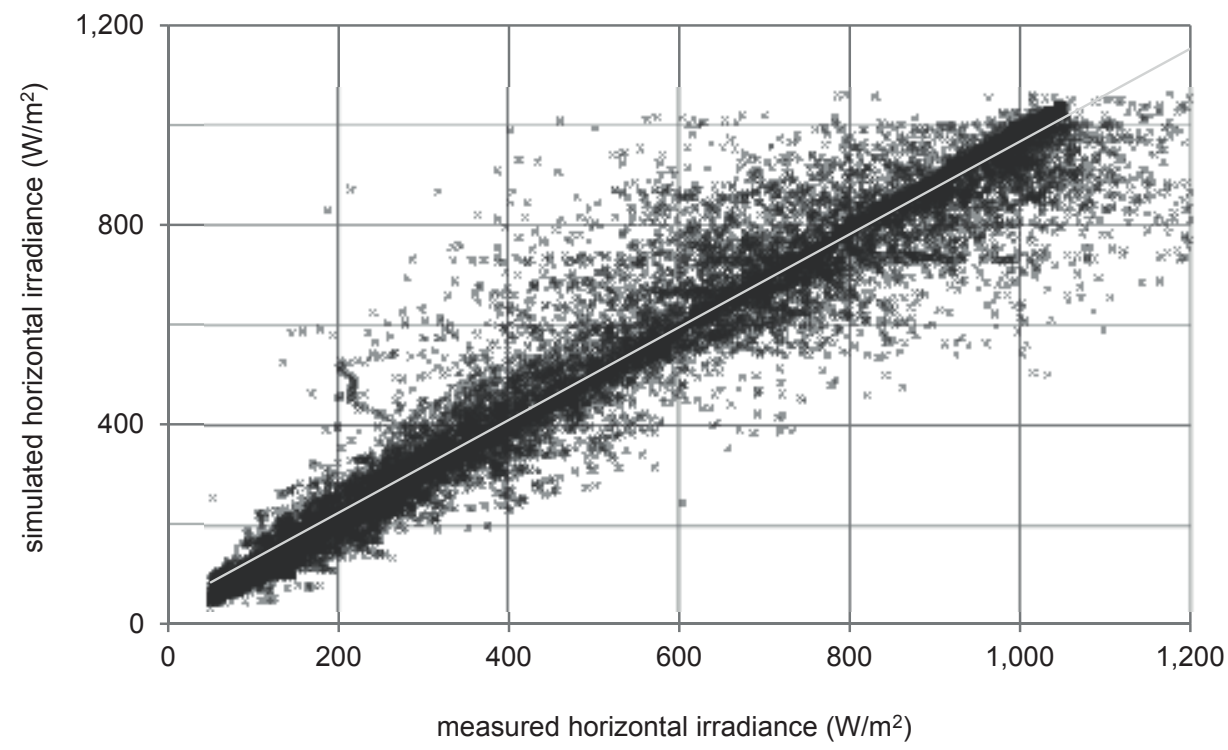

Fig. D.3. Measured vs. simulated minutely horizontal irradiance for Los Angeles, simulation (i).

In Fig. D.4 the results of the horizontal irradiance of the $2^{\text {nd }}$ simulation are shown. Again, most simulated values are in good line with the measurements, although large errors exists, especially for lower irradiance values. Irradiance values above $850 \mathrm{~W} / \mathrm{m}^{2}$ correlate less well, because of the averaged hourly irradiance used as input. Compared with Fig. D.3, irradiance values from $600 \mathrm{~W} / \mathrm{m}^{2}$ correlate better. As can be seen, some simulated values differ a lot from the measured values, especially for low irradiance values. 


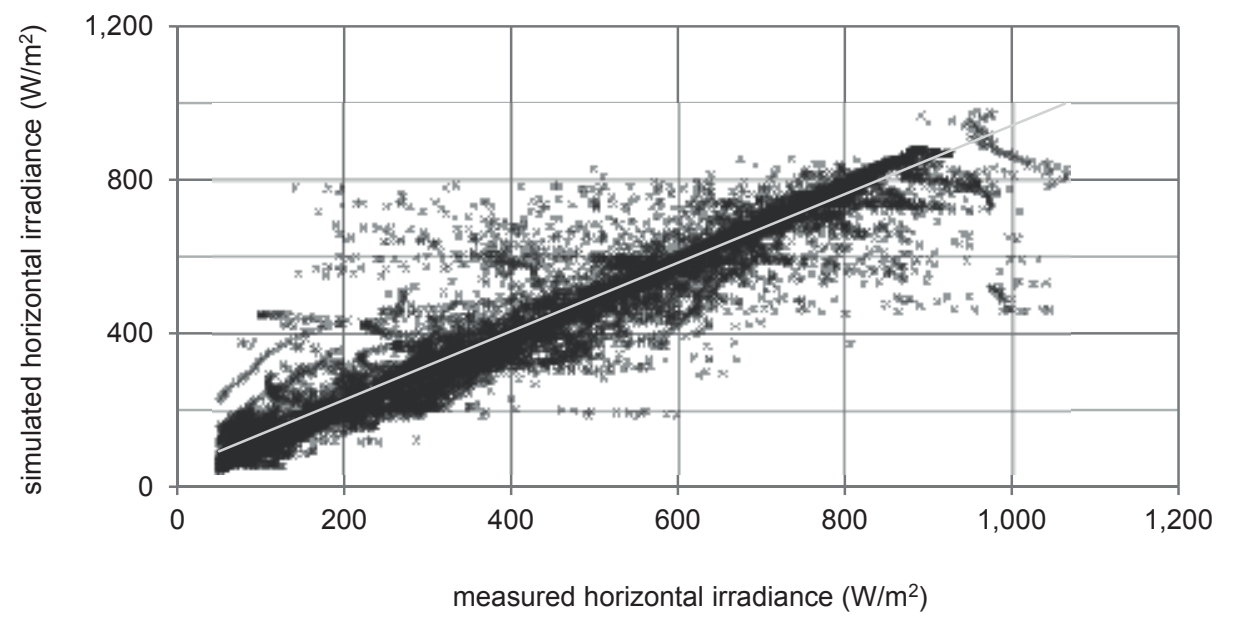

Fig. D.4. Measured vs. simulated minutely horizontal irradiance for Bolzano, simulation (ii).

In Fig. D.5 the results of the $30^{\circ}$ tilted irradiance of the $2^{\text {nd }}$ simulation are shown. Compared with Fig. D.4, the shape of the results is the same, but they are spread over a larger region.

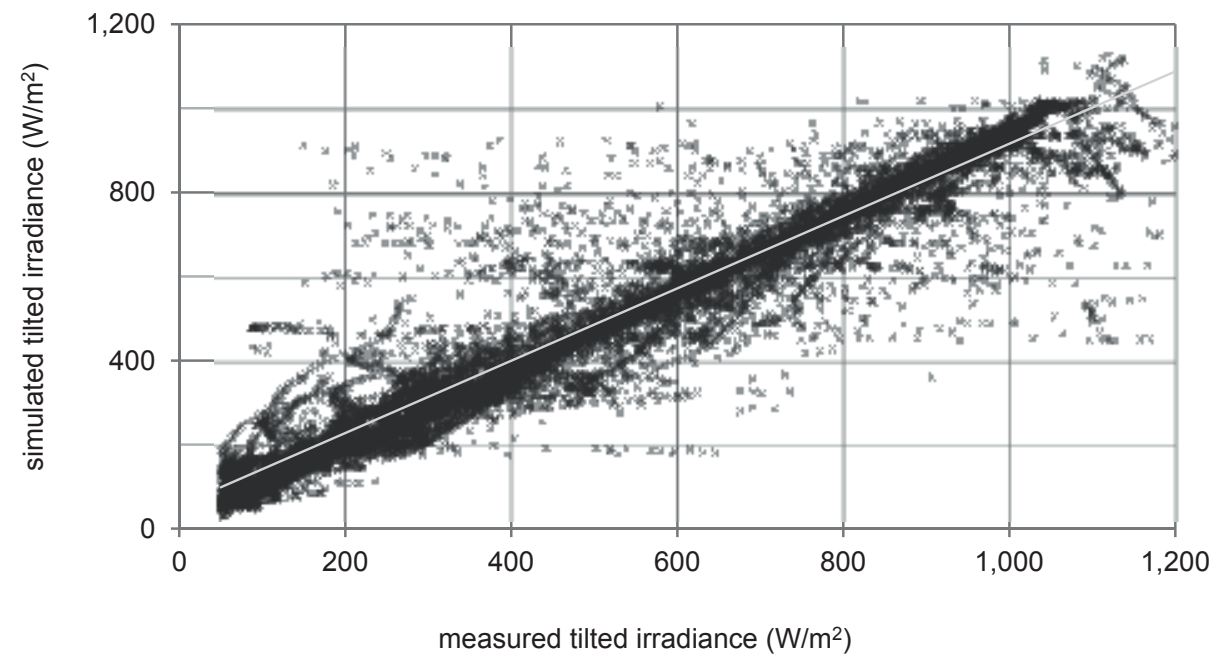

Fig. D.5. Measured vs. simulated minutely $30^{\circ}$ tilted irradiance for Bolzano, simulation (ii).

This can be seen in Fig. D.6 as well, where the average relative error of the simulated irradiance compared to the measurements is shown for the same location per range of 50 $\mathrm{W} / \mathrm{m}^{2}$. 

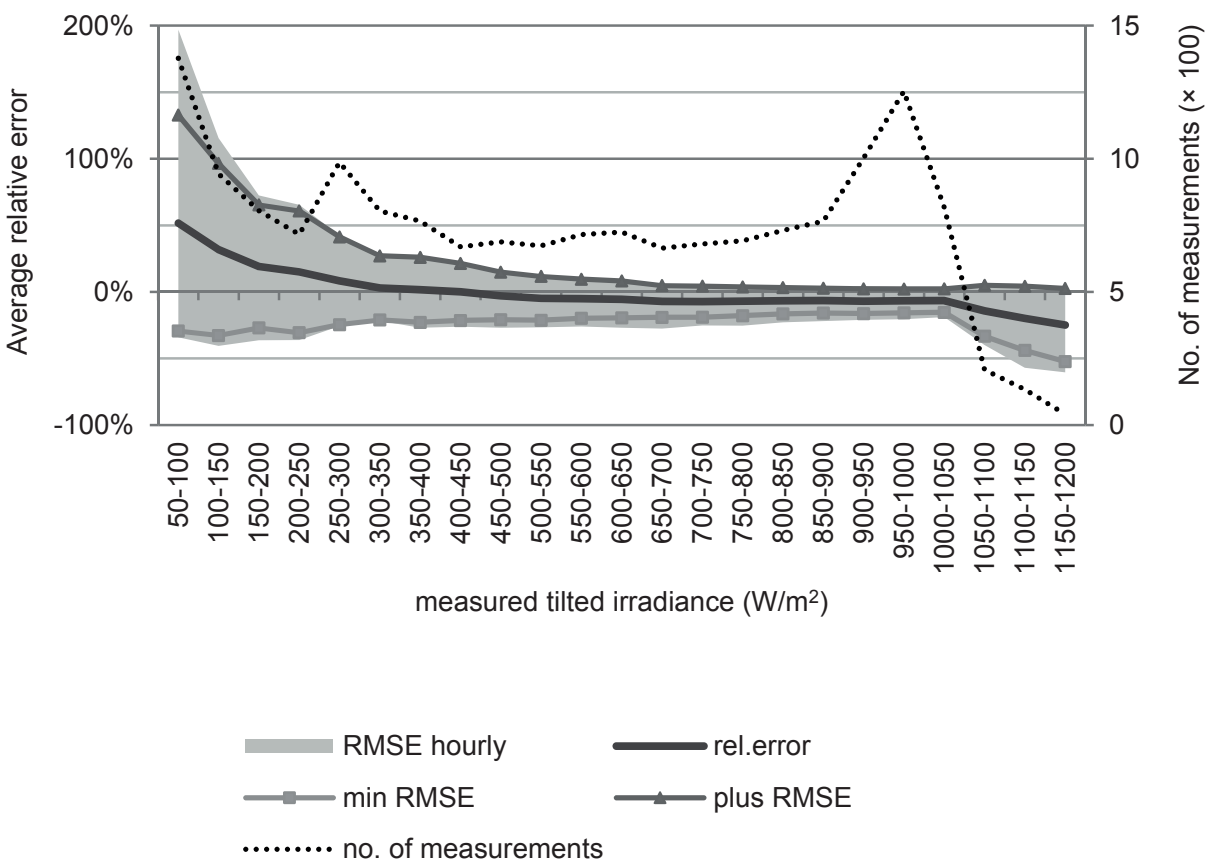

Fig. D.6. Average relative error of the simulated minutely $30^{\circ}$ tilted irradiance for Bolzano per range of $50 \mathrm{~W} / \mathrm{m}^{2}$, simulation (ii) and (iv).

In addition, for each of these ranges the root-mean-square error (RMSE) is plotted in the figure. The RMSE percentage is obtained by dividing the RMSE of the specific range by the average value of the range.

For low irradiance levels, the relative errors are quite large and the number of measurements peaks in this region. However, the absolute error of this area is in the same range compared to irradiance levels around $1,000 \mathrm{~W} / \mathrm{m}^{2}$. The same can be said about the highest irradiance levels $\left(>1,000 \mathrm{~W} / \mathrm{m}^{2}\right)$. The absolute errors are quite large in this region (around $500 \mathrm{~W} / \mathrm{m}^{2}$ ), but the number of measurements in this area is very small compared with the total number of measurements. Therefore, the influence of these larger errors on the total simulation is minor. The average relative error and RMSE for irradiance values between 450 and $1050 \mathrm{~W} / \mathrm{m}^{2}$ are respectively $-6 \%$ and $85 \mathrm{~W} / \mathrm{m}^{2}$ on a minute scale.

In Fig. D.6 the RMSE results of the $4^{\text {th }}$ simulation are shown as well, indicated by the grey area. As can be seen, these values are in the same order as the values from simulation 2.

In Fig. D.7 the results of the $3^{\text {rd }}$ simulation are shown. From the figure follows that the average relative error of the use of the Liu-Jordan model in combination with the OrgillHollands relationship on a minutely basis is in the order of $-3 \%$ for irradiance levels between 300 and $1,050 \mathrm{~W} / \mathrm{m}^{2}$ for a tilt angle of $30^{\circ}$. The average RMSE for this range is 29 $\mathrm{W} / \mathrm{m}^{2}$. 


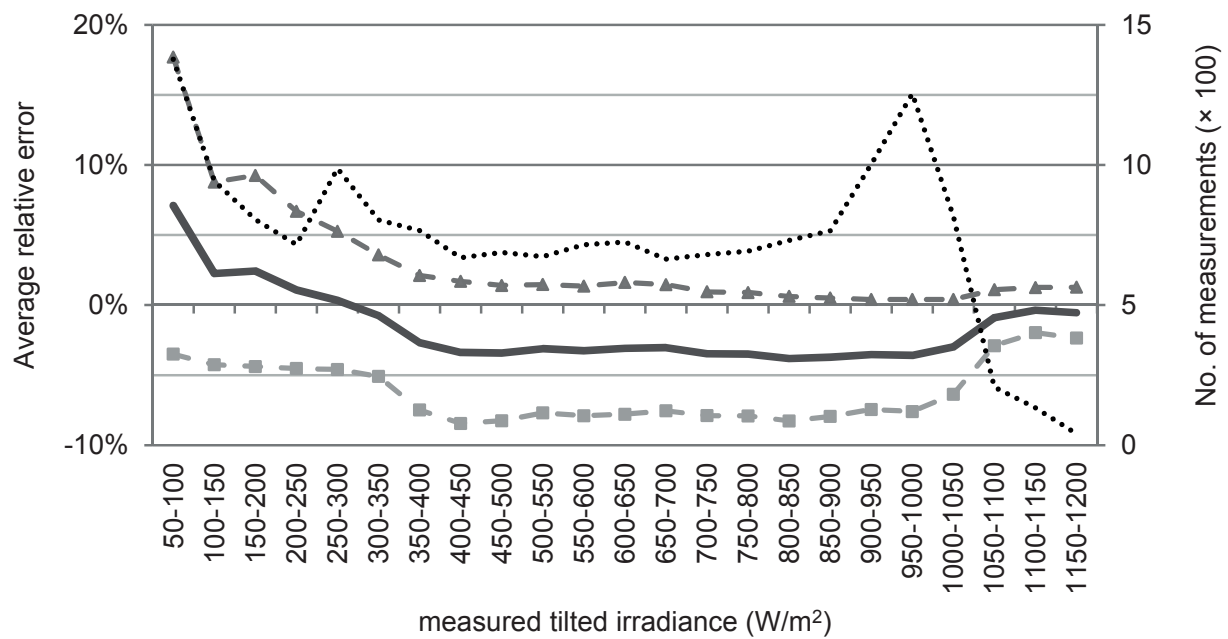

rel. err. $-\div-\min$ RMSE - \pm- plus RMSE $\cdots . . . .$. no. of measurements

Fig. D.7. Average relative error of the simulated minutely $30^{\circ}$ tilted irradiance for Bolzano per range of $50 \mathrm{~W} / \mathrm{m}^{2}$, simulation (iii).

\section{D.5 Conclusions}

In this appendix a new concept of a software tool that can simulate irradiance in realtime is presented. The tool, called VR4PV, is faster than the previously developed tools, which makes it very useful during the design process. Besides, due to the highly modular program structure, it is quite simple to replace implemented models by others. For instance, the Liu-Jordan model can be replaced by the Perez model.

In this appendix, a validation of the tool has been carried out for two locations. For both locations, 1-minute measurements of irradiance have been compared with the simulated irradiance per minute, which have been interpolated between the hourly averaged global horizontal irradiance, used as input in the tool.

Most of the simulated irradiance values correlate well to the measurements. At the higher irradiance levels $\left(500-1,000 \mathrm{~W} / \mathrm{m}^{2}\right)$ the correlation is better compared with lower levels. For a $30^{\circ}$ tilted surface the average RMSE and relative error for irradiance levels between 450 and $1,050 \mathrm{~W} / \mathrm{m}^{2}$ are respectively $85 \mathrm{~W} / \mathrm{m}^{2}$ and $-6 \%$. The errors due to the tilt conversion by the Orgill-Hollands and Liu-Jordan model are respectively $29 \mathrm{~W} / \mathrm{m}^{2}$ and $3 \%$ for the same range and under the same conditions. For irradiance levels between $50-$ $450 \mathrm{~W} / \mathrm{m}^{2}$ the RMSE and the average relative error are respectively $85 \mathrm{~W} / \mathrm{m}^{2}$ and $16 \%$. The use of the Orgill-Hollands and Liu-Jordan model on a minutely basis correspond to the results on an hourly basis, shown in Fig. D.6. The average RMSE for the conversion of hourly to minutely horizontal irradiance is $62 \mathrm{~W} / \mathrm{m}^{2}$ for irradiance levels between $300-$ $850 \mathrm{~W} / \mathrm{m}^{2}$. Therefore the largest error is caused by the assumption of constant irradiance 
between the hourly averaged irradiance values (i.e. the fluctuation of the actual irradiance during an hour).

Although the tool is quite flexible, future work should focus on a good graphical user interface (GUI) which at present is lacking. The GUI is an essential element to let designers and architects adjust parameters during runtime and make successfully use of the VR4PV. The rasterization technique applied lacks the possibility to account for complex reflections and transparent materials, which might be of interest for glazed surroundings like in interior spaces.

Summarizing, the first version of the tool shows promising results. In the forthcoming period the tool will be validated for different components which will give directions to future improvements. Also the use of the tool in a designer setting will be tested for various products and buildings, leading to recommendations for an easily accessible GUI. 


